\title{
FOSSIL AND RECENT BRYOZOA OF THE GULF OF MEXICO REGION
}

\author{
By Ferdinand Canu \\ Of Versailles, France
}

AND

RAY S. BASSLER

Of Washington, D. C.

The extensive dredgings of the United States Fish Commission steamer Albatross in the Gulf of Mexico and adjoining waters, now preserved in the United States National Museum, were consulted from time to time by the authors of the present work during their investigations of North American Tertiary bryozoa with the result that a considerable number of observations upon the Gulf bryozoa had accumulated at the conclusion of these studies. This fact, in conjunction with the interest in the Gulf of Mexico faunas in general and the comparatively small amount of published work upon their bryozoa, afforded the reasons for the present paper. In addition, a collection of fossil bryozoa from Bocas Island, Panama, submitted to us for report by the United States Geological Survey, contained so many forms identical with recent Gulf species that their study was incorporated.

The classic work of Smitt ${ }^{1}$ on Floridan bryozoa collected by Count L. F. de Pourtales during the expeditions of the United States Coast Survey in 1867-1869 in the deeper waters of the Florida region remained practically the only publication until 1914, when Osburn's "Bryozoa of the Tortugas Islands, Florida," 2 dealing with the shallow water faunas, appeared.

\footnotetext{
${ }_{1}$ Smitt, A. F, 1872-73. Floridan Bryozoa, collected by Count L. F. de Pourtales. Kongl. Svenska Vetenskaps-A kademiens Handlingar, pt. 1, 1872, in vol. 10, No. 11, pp. 1-20, pls. 1-4; pt. 2, 1873, in vol. 11, No. 4, pp. 1-83, pls. 1-13. Stockholm.

2 Osburn, R. C., 1914. The Bryozoa of the Tortugas Islands, Florida. Pub. No. 182, Carnegie Institution of Washington, pp. 181-222.
}

No. 2710.-Proceedings U. S. National Museum, Vol. 72, ART. 14 $58513-27-1$ 
Previous to Smitt's work Pourtales ${ }^{3}$ listed and described as new seven species of bryozoa two of which have been found to be synonyms. Levinsen, in his "Morphologic and Systematic Studies on the Cheilostomatous Bryozoa" (1909), records six species from the Florida and West Indian region, two of them new. Since Osburn's paper in 1914 no important work upon the recent bryozoa of the Gulf has been issued, but with the publication of our work ${ }^{4}$ on the Early Tertiary and Later Tertiary and Quaternary Bryozoa of the Atlantic and Gulf Coastal Plains of the United States containing numerous fossil faunas of Gulf origin the study of the recent bryozoa from this region assumes new interest.

More than 40 stations of the Albatross explorations of 1883-1888 have been found to contain bryozoa, some of them in great richness. Most of these stations are located in the Gulf of Mexico, including the Florida Straits and the Straits of Yucatan, although two (D. 2117, D. 2136) from the Caribbean Sea and two (D. 2672, D. 2415) east of Georgia and Florida have been included. Few species occurred at these four stations so that the larger faunas have all been derived from the Gulf of Mexico. We also have been able to include studies on faunas from the vicinity of Miami, Fla., collected by the late John B. Henderson. For convenience of reference, the Gulf Stations can be classified as follows:

D. $2354,2362,2363,2365$, Straits of Yucatan; D. 2152-2343, Gulf of Mexico, north of Habana, Cuba; Fowey Light and D. 2639, 2640, 2647, Straits of Florida; D. 2411, 2413, 2414, 2404, 2405, 2407, 2373, 2387-2392, Cedar Keys, Egmont Key, and Tortugas, Gulf off west coast of Florida.

As in the past, we are under obligations to Mr. F. Julius Fohs, of New York City, who has shown his appreciation of our studies on microorganisms by generous financial assistance in the preparation of this paper.

The bryozoa described by Smitt and by Osburn are cited in the following two lists while those noted in the present paper are given on succeeding pages. Species in the first two lists marked with an asterisk are discussed in this work. The plate and figures cited in the first list refer to Smitt's work while the depth is registered under Osburn's list.

SMITT, FLORIDAN BRYOZOA, 1872

*Crisia denticulata (pl. 1, figs. 1-5). Figure 5=C. ramosa Harmer.

*Diastopora repens (pl. 1, fig. 6)=Plagioecia.

*Idmonea atlantica (pl 2, figs. 7, 8).

*Idmonea serpens? (pl. 2, figs. 9, 10).

${ }^{3}$ Pourtales, L. F. de, 1867. Contributions to the fauna of the Gulf Stream at great depths. Bulletin of the Museum of Comparative Zoology, vol. 1, No. 6. (Bryozoa on pp. 106 and 110.)

${ }_{4}^{4}$ Bulletins 106 and 125, United States National Museum. 
*Crisia hochstetteriana (pl. 2, figs. 11-13)=Crisina canariensis.

*Idmonea milneana (pl. 3, figs. 14-19)=Diaperoecia radicaia.

Filisparsa pourtalesii (pl. 3, figs. 20-22)=Tervia.

*Hornera galeata (pl. 4, figs. 23-25).

*Entalophora proboscideoides (pl. 3, figs. 26, 27).

*Entalophora deflexa (pl. 4, figs. 28-30)=Mecynoecia.

Discoporella clypeiformis (pl. 3, fig. 3)=Lichenopora.

Cellularia pusilla (pl. 4, figs. 32-34)=Scrupocellaria.

Cellularia cornigera (pl. 4, figs. 35-38)=Scrupocellaria.

Cellularia cervicornis (pl. 4, figs. 39-42)=Scrupocellaria.

*Caberea retiformis (pl. 4, figs. 43-46)=Scrupocellaria.

*Halophila johnstoniae (pl. 4, fig. 47).

Bugula flabellata Gray (pl. 4, figs. 48-52).

SMITT, FLORIDAN BRYOZOA, 1873

*Nellia oculata (pl. 1, figs. 53, 54).

Farcimia cereus (pl. 1, figs. 55, 56).

*Cellaria tenuirostris (pl. 1, figs. 57-59)=Cellaria nodosa.

*Vincularia abyssicola (pl. 1, figs. 60,61)=Velumella americana (fig. 60) and Rectonychocella abyssicola (fig. 61).

Membranipora lineata (pl. 2, fig. 62)= Callopora .

* Membranipora irregularis (pl. 2, fig. 63)=Alderina.

Membranipora sigillata (pl. 2, figs. 64-68).

* Membranipora canariensis (pl. 2, figs. 69-71)=Cupuladria.

* Mollia patellaria (pl. 2, fig. 72).

* Mollia antiqua (pl. 3, fig. 73)=Floridina.

* Micropora coriacea (pl. 3, fig. 74).

*Cupularia umbellata (pl. 3, figs. 75-80).

*Cupularia doma (pl, 3, figs. 81-84).

Biflustra lacroixii (pl. 4, figs. 85-88)=Callopora filum.

*Biflustra denticulata (pl. 4, figs. 89-91)=Hemiseptella.

*Biflustra savartii (pl. 4, figs. 92-95)=Acanthodesia.

*Steginoporella elegans (pl. 4, figs. 96-101)=Steganoporella magnilabris.

Steginoporella rozierii (pl, 4, fig. 102)=Thalamoporella.

Membraniporella agassizii (pl. 5, figs. 103-106).

*Cribrilina radiata (pl. 5, figs. 107, 108)= Puellina

*Cribrilina innominaia (pl. 5, figs. 109, 110)=Puellina.

*Cribrilina figularis var. floridana (pl. 5, figs. 111, 112)=Puellina floridana

Escharipora? mucronata (pl. 5, figs. 113-115)=Tremogasterina.

*Porina serrulata (pl. 5, figs. 116-125)=Cigclisula.

Porina violace $a=$ Adeona.

*Porina plagiopora (pl. 6, figs. 134, 135)=Adeona.

*Porellina ciliala (pl. 6, figs. 126-129)=Microporella.

Escharipora stellaia (pl. 6, figs. 130-133)=Triporula.

*Porina subsulcata (pl. 6, figs. 136-140)=Bracebridgia

Anarthropora minuscula (pl. 6, fig. 141).

*Hippothoa? fenestrata (pl. 6, fig. 142)=Stenopsis.

*Tessaradoma boreale (pl. 6, figs. 143-145).

*Mamillopora cupula (pl. 7, figs. 146, 147).

Myriozoum ovum (pl. 7, figs. 148-151).

*Gemellipora eburnea (pl. 7, figs. 152-156=Pasythea.

*Gemellipora lata (pl. 7, fig. 157)=Tremoschizodina.

*Hippothoa porosa (pl. 7, fig. 158)= Mastigophora. 
*Hippothoa pesanseris (pl. 7, figs. 159, 160)=Mastigophora.

*Hippothoa spongites (pl. 8, figs. 161-163)=Stylopoma.

Escharella sanguinea (pl. 8, figs. 164, 165)=Schizobrachiella.

*Hippothoa pertusa isabelleana (pl. 8, figs. 166-168)=Schizopodrella.

Hippothoa mucronata (pl. 8, fig. 169)=Lacerna.

Cellepora verruculata (pl. 8, figs. 170-172).

Hippothoa biaperta (pl. 8, figs. 173-176)=Schizopodrella (Stephanosella).

*Gemellipora eburnea (pl. 9, fig. 178)=Hippothoa.

*Hippothoa divergens (pl. 9, fig. 179)=Buffonellaria.

Hippothoa divergens var. lata (pl. 9, fig. 177)=Buffonellaria lata.

Cellepora tuberosa (pl. 9, fig. 180).

Cellepora gigas (pl. 9, figs. 181, 183-185).

Discopora pertusa (pl. 9, fig. 182 and pl. 11, figs. 240, 241)=Holoporella.

Cellepora coronata (pl. 9, fig. 186).

Cellepora margaritacea (pl. 9, figs. 187-192).

*Cellepora avicularis (pl. 9, figs. 193-198)=Schismopora dichotoma.

Escharella jacotini (pl. 10, fig. 199.)= Smittina trispinosa.

*Escharella jacotini var. spathulata (pl. 10, fig. 200)=Smittina.

Escharella landsborovii (pl. 10, figs. 201, 202)=Smittina?

* Escharella (depressa) rostrigera (pl. 10, figs. 203-205)=Hippaliosina rostrigera.

*Escharella (depressa) setigera (pl. 10, fig. 206)=Crepidacantha setigera.

*Gemellipora striatula (pl. 11, fig. 207)=Tryposiega venusta.

*Gemellipora glabra (pl. 11, figs. 208-210).

Escharella audouinii (pl. 11, fig. 211)=Lepralia.

*Gemellipora limbata (pl. 11, figs. 212-214).

Lepralia inornata (pl. 11, figs. 215, 216)=Trypostega.

* Lepralia cleidostoma (pl. 11, figs. 217-219)= Hippoporina.

* Lepralia edax (forma typica and calcarea) (pl. 11, figs. 220-223)=Hippoporidra edax and $H$. calcarea.

*Lepralia edax janthina (pl. 11, figs. 224-225)=Hippotrema.

*Lepralia turrita (pl. 11, figs. 226-228)=Holoporella.

*Escharella bisinuata (pl. 12, fig. 229)=Petraliella.

Eschara cervicornis (pl. 12, figs. 230-231)=Marguetta or Bryocryptella.

Discopora advena (pl. 12, fig. 232)=Cellepora.

$*$ Discopora albirostris (pl. 12, figs. 334-339)=Holoporella.

Discopora albirostris pusilla (pl. 12, fig. 233)= Holoporella pusilla.

* Retepora (beaniana) reticulata (pl. 13, figs. 242-244) see Bryocryptella.

*Retepora (cellulosa) marsupiata (pl. 13, figs. 245-254).

OSBURN, TORTUGAS ISLANDS, 1914

Pedicellina cernua Pallas (10 fms.).

Barentsia discreta Busk, 1886 (18 fms.).

*Crisia denticulata Lamarck, 1816 (10-15 fms.).

Lichenopora hispida Fleming, 1829 (2 fms.).

*Aetea truncata Landsborough, 1852 (5 fms.).

*Aetea sica Couch, 1844 (10 fms.).

Bugula neritina Linnaeus, 1758 (shallow water).

Bugula neritina minima Waters, 1909 (8 fms.).

Bugula flabellata Gray, 1847 (12 fms.).

Bugula microoecia Osburn, 1914 (18 fms.).

* Bugula caraibica Levinsen, 1909 (shallow water).

Bugula armata Verrill, 1900 (8-10 fms.). 
Beania mirabilis Johnston, 1847 (18 fms.).

Beania intermedia Hincks, 1881 (5-15 fms.).

Beania cupulariensis Osburn, 1914 (10-22 fms.).

*Synnotum aviculare Pieper, 1881 (8-10 fms.)=Bugula avicularia.

*Nellia oculata Busk, 1852 (10-18 fms.).

Scrupocellaria cornigera Pourtales, 1867 (10-15 fms.).

Scrupocellaria cervicornis Busk, 1852 (0-18 fms.).

Canda caraibica Levinsen, 1909 (15 fms.).

*Canda retiformis Pourtales, $1867=$ Scrupocellaria.

*Membranipora membranacea Linnaeus, 1766 (shallow water) =Nitscheina.

?Membranipora lacroixii Audouin, 1826 (8 fms.).

*Membranipora tehuelcha D'Orbigny, 1839 (on gulf weed)=Nitscheina

tuberculata.

*Membranipora irregularis D’Orbigny, 1839 (8-22 fms.)=Alderina.

* Membranipora savartii Audouin, 1826 (10 fms.)=Acanthodesia savartii.

*Cupularia guiniensis Busk, 1854 (10 fms.) =Cupuladria canariensis.

*Cupularia lowei Busk, 1854 (12-22 fms.)=Cupularia umbellata.

*Cribrilina floridana Smitt, 1873 (5-15 fms.)=Puellina.

Arachnopusia monoceros Busk, 1854 (5 fms.).

*Smittipora abyssicola Smitt, 1873 (15 fms.)=Velumella americana

*Steganoporella magnilabris Busk 1854 (15 fms.).

Sieganoporella connexa Harmer, 1900 (12 fms.).

Thalamoporella rozierii Audouin, 1826 (10 fms.).

Thalamoporella granulata Levinsen, 1909 (in drift).

Thalamoporella falcifera Hincks, 1880 (shallow water).

Savignyella lafontii Audouin, 1826 (0-10 fms.).

Hippothoa distans MacGillivray, 1868 (0-12 fms.).

*Trypostega venusta Norman, 1864 (5-15 fms.).

*Adeona violacea Johnston, 1874 (5-18 fms.)=Adeona plagiopora.

*Bracebridgia subsulcata Smitt, 1873 (10-12 fms.).

*Retepora marsupiata Smitt, 1873 (10-18 fms.).

Rhynchozoon tuberculatum Osburn, 1914 (18 fms.).

Rhynchozoon solidum Osburn, 1914 (8 fms.).

Arborella dichotoma Osburn, 1914 (10 fms.)=Pollaploecium.

*Tubucellaria cereoides Solander, 1756 (15 fms.).

Escharella costifera Osburn, 1914 (2 fms.)=Peristomella.

Schizoporella biaperta Michelin, $1842 \quad(0-22$ fms. $)=$ Schizopodrella (Stephanosella).

*Schizoporella floridana Osburn, 1914 (15-18 fms.)=Schizopodrella.

Schizoporella sanguinea Norman, 1868 (15 fms.)=Schizobrachiella.

Schizoporella unicornis Johnston, 1847 (1-10 fms.)=Schizopodrella.

*Schizoporella spongites Pallas, 1766 (0-18 fms.)=Stylopoma.

*Escharina pesanseris Smitt, 1873 (8 fms.)= Mastigophora.

* Microporella ciliata Pallas, 1766 (5-18 fms.).

*Smittina trispinosa Johnston, 1838 (0-12 fms.).

Lepralia audouinii D'Orbigny, 1852 (0-10 fms.).

*Lepralia porcellana Busk, 1860 (5-15 fms.)=Hippoporina cleidostoma.

Lepralia uvulifera Osburn, 1914 (10 fms.).

Lepralia cucullata Busk, 1854 (near surface)=Watersipora.

*Lepralia rostrigera Smitt, 1873 (10-15 fms.)=Hippaliosina.

Lepralia contracta Waters var. serrata Osburn, 1914 (5-18 fms.).

*Lepralia edax Busk, 1859 (18 fms.)=Hippoporidra calcarea.

*Lepralia janthina Smitt, 1873 (6 fms.)=Hippotrema. 
Phylactella labrosa Busk, 1854 (22 fms.).

Phylactella collaris Norman, var. aviculifera Osburn, 1914 (1-15 fms.).

*Cellepora dichotoma Hincks, 1862 (10 fms)=Schismopora.

Cellepora verruculata Smitt, 1872 (0-15 fms.).

Lagenipora ignota Norman, 1909 (12 fms.)=Costazzia.

*Holoporella albirostris Smitt, 1873 (0-15 fms.).

Holoporella pusilla Smitt, 1873 (low tide).

*Holoporella magnifica Osburn, 1914 (10 fms.).

*Holoporella turrita Smitt, 1873 (12-15 fms.).

* Petralia bisinuata Smitt, 1873 (10-18 fms.)=Petraliella.

Bowerbankia gracilis Leidy, 1855 (shallow).

Zoobotryon pellucidum Ehrenberg, 1831 (shallow).

Cylindroecium giganteum Busk, 1865 (0-several fms.).

Anguinella palmata Van Beneden, 1844 (shallow).

Amathia goodei Verrill, 1901 (shallow).

D. 2004. Atlantic Ocean, east of Cape Hatteras; $37^{\circ} 19^{\prime} 45^{\prime \prime}$ N.; $74^{\circ} 26^{\prime} 06^{\prime \prime}$ W.;

102 fms.; green mud, shells; March 23, 1883:

Cellaria sinuosa Hassall, 1842.

D. 2117. Caribbean Sea; $15^{\circ} 24^{\prime} 40^{\prime \prime}$ N.; $63^{\circ} 31^{\prime} 30^{\prime \prime}$ W.; 683 fms.; yellow mud, fine sand; bottom temp. $39.7^{\circ}$; January 17,1884 :

Levinsenella brasiliensis Busk, 1884.

Retepora marsupiata Smitt, 1873.

Tessaradoma gracile Sars, 1850, var.

D. 2136. Caribbean Sea; $17^{\circ} 43^{\prime} 40^{\prime \prime}$ N.; $75^{\circ} 38^{\prime} 25^{\prime \prime}$ W.; 52 fms.; coral, broken shells; February 29, 1884:

Quadricellaria caraibica, new species.

Tremogasterina malleolus, new species.

D. 2152. 2.5 miles nw. of Habana Light; $387 \mathrm{fms}$; coral; bottom temp. $49^{\circ}$; April 30, 1884:

Cribrilina lineata, new species.

Gemellipora (?) limbata Smitt, 1873.

Microporella ampla, new species.

Rectonychocella abyssicola Smitt, 1873.

Tremoschizodina lata Smitt, 1873.

D. 215\%. Gulf of Mexico, off Habana; $23^{\circ} 10^{\prime} 04^{\prime \prime}$ N.; $82^{\circ} 21^{\prime} 07^{\prime \prime}$ W.; 29 fms.; April 30, 1884:

Gemelliporidra magniporosa Canu and Bassler, 1923.

D. 2160. Off Habana, Cuba; $23^{\circ} 10^{\prime} 31^{\prime \prime} \mathrm{N}$.; $82^{\circ} 20^{\prime} 37^{\prime \prime} \mathrm{W} . ; 167 \mathrm{fms}$.; coral; April 30, 1884:

Dacryonella typica, new species.

Holoporella tubulosa, new species.

D. 216\%. Off Habana, Cuba; $23^{\circ} 10^{\prime} 40^{\prime \prime}$ N.; $82^{\circ} 20^{\prime} 30^{\prime \prime}$ W.; 201 fms.; coral; May 1, 1884:

Antropora pustulata, new species.

Buffonellaria divergens Smitt, 1873.

Callopora curvirostris Hincks, 1861.

Crepidacantha longiseta, new species.

Figularia (?) ampla, new species.

Gemelliporidra typica Canu and Bassler, 1927.

Hincksina periporosa, new species.

Hippoporina cleidostoma Smitt, 1873.

Marssonopora uncifera, new species.

Membraniporella petasus, new species.

Trypostega venusta Norman, 1864. 
D. 2319. North of Cuba; $23^{\circ} 10^{\prime} 37^{\prime \prime}$ N.; $82^{\circ} 20^{\prime} 06^{\prime \prime}$ W.; 143 fms.; gray coral; January 17, 1885:

Adeona plagiopora Smitt, 1873. Alderina irregularis Smitt, 1873.

Callopora caudata, new species.

Callopora curvirostris Hincks, 1861.

Dacryonella typica, new species.

Diplosolen obelium Johnston, 1848.

Gemelliporidra typica Canu and Bassler, 1927.

Gephyrotes spinosum, new species.

Hincksina periporosa, new species.

Hippaliosina rostrigera Smitt, 1873.

Holoporella turrita Smitt, 1873.

Holoporella tubulosa, new species.

Hornera galeata Smitt, 1872.

Lagenipora verrucosa, new species.

Lichenopora radiata Auduoin, 1826.

Marssonopora uncifera, new species.

Mastigophora pesanseris Smitt, 1873,

Membraniporella petasus, new species.

Membrendoecium strictorostris, new species.

Proboscina robusta, new species.

Stylopoma spongites Pallas, 1766.

Tremogasterina lanceolata, new species.

$V$ elumella americana, new species.

Fowey Light, Atlantic, 15 mi. s. Miami, Fla.; 40 fms.; collected by J. B. Henderson, November, 1914:

Adeona plagiopora Smitt, 1873.

Bracebridgia subsulcata Smitt, 1873.

Cigclisula serrulata Smitt, 1873.

Cupuladria canariensis Busk, 1852.

Exéchonella pumicosa, new species.

Floridina antiqua, Smitt, 1873.

Floridinella typica, new species.

Gemellipora glabra Smitt, 1873.

Hippoporina cleidostoma Smitt, 1873.

Hippoporidra calcarea Smitt, 1873.

Hippodiplosia aculeata, new species.

Holoporella turrita Smitt, 1873.

Holoporella vagans Busk, 1885.

Mamillopora cupula Smitt, 1873.

Mastigophora pesanseris Smitt, 1873.

Mastigophora porosa Smitt, 1873.

Microporella ciliata Linnaeus, 1759.

Puellina radiata Moll, 1803.

Schismopora dichotoma Hincks, 1864.

Siphonoporella granulosa, new species.

Smittina trispinosa spathulata Smitt, 1873.

Steganoporella magnilabris Busk, 1854.

Tremogasterina granulata, new species.

Tremoschizodina lata Smitt, 1873.

Tubucellaria cereoides Ellis and Solander, 1780

Velumella americana, new species. 
D. 2169. Off Habana, Cuba; $23^{\circ} 10^{\prime} 28^{\prime \prime}$ N.; $82^{\circ} 20^{\prime} 27^{\prime \prime}$ W.; $78 \mathrm{fms}$; coral; May 1, 1884:

Acanthocella clypeata, new species.

Aplousina tuberosa, new species.

Crepidacantha longiseta, new species.

Gemelliporidra magniporosa Canu and Bassler, 1923.

Puellina radiata Moll, 1803.

D. 2317. North of Cuba; $24^{\circ} 25^{\prime} 45^{\prime \prime}$ N.; $81^{\circ} 46^{\prime} 45^{\prime \prime}$ W.; $45 \mathrm{fms}$; coral; $75^{\circ}$ bottom temp.; June 15, 1885:

Aplousina tuberosa, new species.

Crisia denticulata Lamarck, 1812.

Hippothoa eburnea Smitt, 1873.

D. 2320. North of Cuba; $23^{\circ} 10^{\prime} 39^{\prime \prime}$ N.; $82^{\circ} 18^{\prime} 48^{\prime \prime}$ W.; 130 fms.; fine coral; January 17, 1885:

Buffonellaria divergens Smitt, 1873.

Dacryonella typica, new species.

Gemellipora (?) limbala Smitt, 1873.

Hippotrema janthina Smitt, 1873.

Lagenipora verrucosa, new species.

Lichenopora buski Harmer, 1915.

Puellina innominata Couch, 1844.

Stylopoma spongites Pallas, 1766.

Tremogasterina lanceolata, new species.

D. 2321. North of Cuba; $23^{\circ} 10^{\prime} 54^{\prime \prime}$ N.; $82^{\circ} 18^{\prime} 00^{\prime \prime}$ W.; $230 \mathrm{fms}$.; fine gray sand; January 17, 1885:

Antropora pustulata, new species.

Diplosolen obelium Johnston, 1848.

D. 2322. North of Cuba; $23^{\circ} 10^{\prime} 54^{\prime \prime}$ N.; $82^{\circ} 17^{\prime} 45^{\prime \prime}$ W.; $115 \mathrm{fms}$.; coral; January 17, 1885:

Gemelliporella asper Canu and Bassler, 1923.

Velumella americana, new species.

D. 2324. North of Cuba; $23^{\circ} 10^{\prime} 25^{\prime \prime}$ N.; $82^{\circ} 20^{\prime} 24^{\prime \prime}$ W.; 33 fms.; coral; bottom temp. $79.1^{\circ}$; January 17,1885 :

Adeona plagiopora Smitt, 1873.

Lagenipora verrucosa, new species.

Steganoporella magnilabris Busk, 1854.

D. 2327. North of Cuba; $23^{\circ} 11^{\prime} 45^{\prime \prime}$ N.; $82^{\circ} 17^{\prime} 54^{\prime \prime}$ W.; $182 \mathrm{fms}$.; fine brown sand; January 17, 1885:

Steganoporella magnilabris Busk, 1854.

D. 2330. North of Cuba; $23^{\circ} 10^{\prime} 48^{\prime \prime}$ N.; $82^{\circ} 19^{\prime} 15^{\prime \prime}$ W.; 121 fms.; fine gray coral; January 17, 1885:

Gemelliporidra typica Canu and Bassler, 1927.

D. 2331. North of Cuba; $23^{\circ} 10^{\prime} 31^{\prime \prime}$ N.; $82^{\circ} 19^{\prime} 55^{\prime \prime}$ W.; 114 fms.; coral; January 17,1885 :

Pasythea eburnea Smitt, 1873.

D. 2334. North of Cuba; $23^{\circ} 10^{\prime} 42^{\prime \prime}$ N.; $82^{\circ} 18^{\prime} 24^{\prime \prime}$ W.; $67 \mathrm{fms}$.; white coral; January 19, 1885:

Crepidacantha longiseta, new species.

Lichenopora radiata Audouin, 1826.

Trypostega venusta Norman, 1864.

D. 2339. North of Cuba; $23^{\circ} 10^{\prime} 40^{\prime \prime} \mathrm{N}$.; $82^{\circ} 20^{\prime} 15^{\prime \prime} \mathrm{W} . ; 191 \mathrm{fms}$ :

Smittina labellum, new species. 
D. 2343. North of Cuba; $23^{\circ} 11^{\prime} 35^{\prime \prime} \mathrm{N} . ; 82^{\circ} 19^{\prime} 25^{\prime \prime} \mathrm{W} . ; 279$ fms.; fine coral; January 19, 1885:

Bryocryptella reticulata, new species.

D. 2354. East of Yucatan; $20^{\circ} 59^{\prime} 30^{\prime \prime}$ N.; $86^{\circ} 23^{\prime} 45^{\prime \prime}$ W.; $130 \mathrm{fms}$.; coral; January 22, 1885:

Dendrobeania lamellosa, new species.

Reteporella prominens, new species.

D. 2362. East of Yucatan; $22^{\circ} 08^{\prime} 30^{\prime \prime}$ N.; $86^{\circ} 53^{\prime} 30^{\prime \prime} \mathrm{W}$.; 25 fms.; coarse sand; January 30, 1885:

Gemelliporidra magniporosa Canu and Bassler, 1923.

Hippothoa eburnea Smitt, 1873.

Hippodiplosia pertusa Esper, 1794.

Holoporella subalba, new species.

Petraliella bisinuata Smitt, 1873.

Smittina trispinosa spathulata Smitt, 1873.

D. 2363. East of Yucatan; $22^{\circ} 07^{\prime} 30^{\prime \prime}$ N.; $87^{\circ} 06^{\prime} 00^{\prime \prime}$ W.; 21 fms.; coral; January 30,1885 :

Hippoporidra edax Busk, 1859.

Holoporella magnifica Osburn, 1914.

Holoporella subalba, new species.

Metrarabdotos unguiculatum, new species.

Petraliella bisinuata Smitt, 1873.

Schizopodrella floridana Osburn, 1914.

D. 2365. East of Yucatan; $22^{\circ} 18^{\prime} 00^{\prime \prime}$ N.; $87^{\circ} 04^{\prime} 00^{\prime \prime}$ W.; 24 fms.; coral; Jan uary 30,1885 :

A plousina tuberosa, new species.

Callopora tenuirostris Hincks, 1880.

Hippoporina cleidostoma Smitt, 1873.

Holoporella subalba, new species.

Holoporella turrita Smitt, 1873.

Schizopodrella falcifera, new species.

Smittina trispinosa spathulata Smitt, 1873.

Steganoporella magnilabris Busk, 1854.

D. 2366. Gulf of Mexico, off Yucatan; $43 \mathrm{fms}$; fine white coral; January 30, 1885:

Petraliella marginata, new species.

D. 2373. Gulf of Mexico, northern part; $29^{\circ} 14^{\prime} 00^{\prime \prime}$ N.; $85^{\circ} 29^{\prime} 15^{\prime \prime}$ W.; 25 fms.; coral; February 7, 1885:

Acanthocella clypeata, new species.

D. 2387.5 Gulf of Mexico, northern part; $29^{\circ} 24^{\prime} 00^{\prime \prime}$ N.; $88^{\circ} 04^{\prime} 00^{\prime \prime}$ W.; $32 \mathrm{fms}$; sand, gravel, broken shells; March 4, 1885:

Cystisella americana, new species.

Hippoporidra calcarea Smitt 1873.

D. 2388. Gulf of Mexico, northern part; $29^{\circ} 24^{\prime} 30^{\prime \prime}$ N.; $88^{\circ} 01^{\prime} 00^{\prime \prime}$ W.; $35 \mathrm{fms.;}$ yellow sand, black specks; March 4, 1885:

Cellaria nodosa, new name.

D. 2389. Gulf of Mexico, northern part; $29^{\circ} 28^{\prime} 00^{\prime \prime}$ N.; $87^{\circ} 56^{\prime} 00^{\prime \prime}$ W.; 27 fms.; gray sand, broken shells; March 4, 1885:

Acanthodesia savarti Savigny-Audouin, 1826.

Mucronella egyptiaca Waters, 1909.

${ }^{5}$ Studies of material from stations D. 2387 , D. 2388 , and D. 2389 discovered since the completion of this work show the presence of many more species than those here listed. 
D. 2392. Gulf of Mexico, northern part; $28^{\circ} 47^{\prime} 30^{\prime \prime}$ N.; $87^{\circ} 27^{\prime} 00^{\prime \prime}$ W.; 724 fms.; brown gray mud, bottom temp. $40.7^{\circ}$; March 13, 1885:

Bugula avicularia Linnaeus, 1758.

Semihaswellia sinuosa, new species.

D. 2404. Gulf of Mexico, west of Florida; $28^{\circ} 44^{\prime} 00^{\prime \prime}$ N.; $85^{\circ} 38^{\prime} 25^{\prime \prime}$ W.; 60 fms.; gray sand; March 15, 1885 :

Tremogasterina malleolus, new species.

D. 240\%. Gulf of Mexico, west of Florida; $28^{\circ} 47^{\prime} 30^{\prime \prime}$ N.; $84^{\circ} 37^{\prime} 00^{\prime \prime}$ W.; 24 fms.; coral, broken shells; March 15, 1885 :

Nellia oculata Busk, 1852.

D. 2411. Gulf of Mexico, west of Florida; $26^{\circ} 33^{\prime} 30^{\prime \prime}$ N.; $83^{\circ} 15^{\prime} 30^{\prime \prime}$ W.; 27 fms.; fine white sand, black specks; March 18, 1885:

Mamillopora cupula Smitt, 1873.

Retepora marsupiata Smitt, 1872.

D. 2405. Gulf of Mexico, west of Florida; $28^{\circ} 45^{\prime}$ N.; $85^{\circ} 02^{\prime}$ W.; 30 fms; gray sand; March 15, 1885:

Adeona plagiopora Smitt, 1873.

A tea truncata Landsborough, 1852.

Acanthodesia savarti Savigny-Audouin, 1826.

Alderina irregularis Smitt, 1873.

Aplousina gigantea Canu and Bassler, 1927.

A plousina tuberosa, new species.

Bracebridgia subsulcata Smitt, 1873.

Buffonellaria reticulata, new species.

Callopora tenuirostris Hincks, 1880.

Canda retiformis Pourtales, 1867.

Cauloramphus opertus, new species.

Chaperia galeata Busk, 1852.

Crisia denticulata Lamarck, 1812.

Crisia elongata Milne Edwards, 1838.

Cupuladria canariensis Busk, 1852.

Diaperoecia radicata Kirkpatrick, 1888.

Domopora floridina, new species.

Fenestrulina malusi Savigny-Audouin, 1826.

Floridina antiqua Smitt, 1873.

Gemellipora glabra Smitt, 1873.

Halophila johnstoniae Gray, 1843.

Hippaliosina rostrigera Smitt, 1873.

Hincksina periporosa, new species.

Hippomenella rubra, new species.

Hippoporina cleidostoma Smitt, 1873.

Hippothoa eburnea Smitt, 1873.

Holoporella albirostris Smitt, 1873.

Holoporella magnifica Osburn, 1914.

Mamillopora cupula Smitt, 1873.

Mastigophora porosa Smitt, 1873.

Mecynoecia deflexa Smitt, 1873.

Metrarabdotos unguiculatum, new species.

Micropora coriacea Esper, 1791.

Microporella ciliata Linnaeus, 1759.

Mollia patellaria Smitt, 1873.

Nellia oculata Busk, 1852.

Petraliella marginata, new species. 
Puellina floridana Smitt, 1873.

Puellina innominata, Couch, 1844.

Schizopodrella incrassata, new species.

Siphonoporella dumonti, new species.

Siphonoporella granulosa, new species.

Steganoporella magnilabris Busk, 1854.

Stenopsis fenestrata Smitt, 1873.

Stylopoma spongites Pallas, 1766.

Tremoschizodina lata Smitt, 1873.

Trypostega venusta Norman, 1864.

Vellumella americana, new species.

D. 2413. Gulf of Mexico, southwest of Florida; $26^{\circ} 00^{\prime} 00^{\prime \prime} \mathrm{N}$.; $82^{\circ} 57^{\prime} 30^{\prime \prime} \mathrm{W}$.; $24 \mathrm{fms}$; fine sand, black specks; broken shells; March 19, 1885:

Bugula (Stirparia) caraibica Levinsen, 1909.

D. 2414. Gulf of Mexico, southwest of Florida; $25^{\circ} 04^{\prime} 30^{\prime \prime}$ N.; $82^{\circ} 59^{\prime} 15^{\prime \prime} \mathrm{W}$.;

26 fms.; fine white sand, broken shells; March 19, 1885:

Petraliella bisinuata Smitt, 1873.

Petraliella marginata, new species.

D. 2415. Atlantic, east of Florida; $30^{\circ} 44^{\prime} 00^{\prime \prime}$ N.; $79^{\circ} 26^{\prime} 00^{\prime \prime}$ W.; $440 \mathrm{fms}$.:

Holoporella tubulosa, new species.

D. 2619. Western Atlantic; $33^{\circ} 38^{\prime}$ N.; $77^{\circ} 36^{\prime}$ W.; 15 fms.; coarse yellow sand and broken shells; October 20, 1885 :

Hemiseptella hexagonalis, new species.

D. 2640. Straits of Florida; $25^{\circ} 05^{\prime} 00^{\prime \prime} \mathrm{N}$.; $80^{\circ} 15^{\prime} 00^{\prime \prime}$ W.; 56 fms.; coral sand; April 9, 1886:

Hippoporidra calcarea Smitt, 1873.

D. 2647 . Straits of Florida; $25^{\circ} 48^{\prime} 00^{\prime \prime}$ N.; $80^{\circ} 04^{\prime} 00^{\prime \prime}$ W.; $85 \mathrm{fms}$.; gray sand, foraminifera; April 9, 1886:

Nitscheina tuberculata Bosc, 1802.

D. 2650. Bahama Islands; $23^{\circ} 34^{\prime} 30^{\prime \prime}$ N.; $76^{\circ} 34^{\prime} 00^{\prime \prime}$ W.; 369 fms.; coarse white sand; bottom temp. $57.8^{\circ}$; April 12, 1886:

Palmicellaria aviculifera, new species.

Puellina radiata Moll, 1803.

D. 2672. Atlantic, east of Georgia; $31^{\circ} 31^{\prime} \mathrm{N}$.; $79^{\circ} 5^{\prime} \mathrm{W}$.; $277 \mathrm{fms}$; c coarse brown sand; bottom temp. $54.3^{\circ}$; May 5, 1886 :

Aetea sica Couch, 1844.

Hippothoa eburnea Smitt, 1872.

Puellina innominata Couch, 1844.

Tremogasterina ventricosa, new species.

D. 2639. Straits of Florida; $25^{\circ} 04^{\prime} 50^{\prime \prime}$ N.; $80^{\circ} 15^{\prime} 10^{\prime \prime}$ W.; 56 fms.; coarse sand; April 9, 1886:

Adeona plagiopora Smitt, 1873.

Alderina irregularis Smitt, 1873.

Aplousina gigantea Canu and Bassler, 1927.

Aplousina tuberosa, new species.

Callopora pumicosa, new species.

Callopora tenuirostris Hincks, 1880.

Canda retiformis Pourtales, 1867.

Cigclisula serrulata Smitt, 1873.

Crepidacantha setigera Smitt, 1873.

Cupuladria canariensis Busk, 1852.

Cupularia doma D'Orbigny, 1852.

Diaperoecia radicata Kirkpatrick, 1888. 
Floridina antiqua Smitt, 1873.

Floridinella parvula, new species.

Floridinella typica, new species.

Gemellipora glabra Smitt, 1873.

Gephyrotes spinosum, new species.

Hincksina periporosa, new species.

Hippoporina cleidostoma Smitt, 1873.

Holoporella albirostris Smitt, 1873.

Holoporella vagans Busk, 1885.

Lagenipora verrucosa, new species.

Lepralia palliolata, new species.

Mamillopora cupula Smitt, 1873.

Mastigophora pesanseris Smitt, 1873.

Mastigophora porosa Smitt, 1873.

Mecynoecia deflexa Smitt, 1872.

Metrarabdotos unguiculatum, new species.

Microporella ciliata Linnaeus, 1759.

Micropora coriacea Esper, 1891.

Oncousoecia arcuata, new species.

Peristomoecia floridana, new species.

Plagioecia dispar, new species.

Puellina innominata, Couch, 1844.

Schismopora dichotoma Hincks, 1864.

Schizopodrella incrassata, new species.

Siphonoporella granulosa, new species.

Smittina trispinosa spathulata Smitt, 1873.

Steganoporella magnilabris Busk, 1854.

Tremogasterina granulata, new species.

Tremoschizodina lata Smitt, 1873.

Trypostega venusta Norman, 1864.

D. 2662. Western Atlantic; $29^{\circ} 24^{\prime} 30^{\prime \prime}$ N.; $79^{\circ} 43^{\prime}$ W.; 434 fms.; gray sand and broken shells; March 4, 1886:

Cellepora minutiporosa, new species.

D. 2782. Off Chili, South America; $51^{\circ} 12^{\prime} 00^{\prime \prime}$ S.; $74^{\circ} 13^{\prime} 30^{\prime \prime} \mathrm{W}$.; 258 fms.;

bottom temp. $47.9^{\circ}$; February 6,1888 :

Nitscheina membranacea Linnaeus, 1766.

Cedar Keys, West Coast of Florida (Levy County):

Hippadenella floridana, new species.

Rhamphostomella magnirostris, new species.

Umbonula undulata, new species.

Egmont Key, Florida, at entrance to Tampa Bay:

Crisulipora orientalis, new species.

Diaperoecia radicata Kirkpatrick, 1888.

Mecynoecia deflexa Smitt, 1872.

\section{PLIOCENE BRYOZOA OF PANAMA}

The great antiquity of the Gulf fauna is exemplified in the fossil bryozoa from Bocas Island, Panama, the study of which is incorporated in the present work. This collection, originally submitted to us for age determination, proved upon detailed study to contain so many recent species that we pronounced these fossils as Pleistocene. We 
are informed by the collector, A. A. Olsson, that the rocks yielding the collection are all involved in the folding and structure of Bocas Island and that they can not be younger than Pliocene. It is, therefore, possible that in spite of their very recent aspect these fossils may be of still greater age than Pliocene. The list of this fauna follows, species still living in the Gulf of Mexico being marked with an asterisk.

PLIOCENE; MINNITIMMI CREEK, BOCAS ISLAND, ALMIRANTE BAY, PANAMA

* Aetea truncata Lansborough, 1852.

*Alderina irregularis Smitt, 1873.

Alderina pyriformis, new species.

*Callopora curvirostris Hincks, 1861.

*Cellaria nodosa, new name.

Coleopora granulosa, new species.

Crepidacantha poissoni Savigny-Audouin, 1826

*Crisia elongata Milne-Edwards, 1838.

*Cupuladria canariensis Busk, 1852.

*Dacryonella typica, new species.

*Entalophora proboscideoides Smitt, 1872.

Gemelliporidra multilamellosa Canu and Bassler, 1923.

*Hippoporina cleidostoma Smitt, 1873.

*Hippopodina feegensis Busk, 1880.

*Hippodiplosia pertusa Esper, 1794.

*Holoporella vagans Busk, 1885.

*Idmonea atlantica Forbes, 1847.

Lepralia fissurata, new species.

Lichenopora buskiana, new name.

*Mastigophora pesanseris Smitt, 1873.

Microporella normani, new name.

*Nellia oculata Busk, 1852.

*Petraliella bisinuata Smitt, 1873.

Petraliella bisinuata grandis, new variety.

*Plagioecia sarniensis Norman, 1864.

*Puellina radiata Moll, 1823.

Rhynchozoon corniger, new species.

*Schismopora dichotoma Hincks, 1869.

* Scrupocellaria retiformis Pourtales, 1867.

* Schizopodrella isabelleana Smitt, 1873.

*Siphonoporella granulosa, new species.

*Smittina trispinosa spathulata Smitt, 1873.

Steganoporella brevis, new species.

*Steganoporella magnilabris Busk, 1854.

*Stylopoma spongites Pallas, 1766.

*Tremopora radicifera Hincks, 1869.

*Tremogasterina granulata, new species.

*Tremogasterina malleolus, new species.

Tremogasterina sparsiporosa, new species.

Tremoschizodina anatina, new species.

*Tubucellaria cereoides Ellis and Solander, 1786.

Vibracellina laxibasis, new species. 


\section{Order CHEILOSTOMATA Busk}

\section{Suborder ANASCA Levinsen}

\section{Division MALACOSTEGA Levinsen, 1909}

\section{Family BIFLUSTRIDAE Smitt, 1872}

Membraniporae without ovicells. The zooecia are rectangular (seen on their dorsal face). No spines.

In this family we classify all the genera of the first group of Membraniporae as we divided them in 1920 (p. 85).

History.-Biflustra is a zoarial genus established by D'Orbigny, 1852 , and classed in his family of Flustrellariidae. It embraced all of the bilamellar Membranipores. Three recent species were classed here-the first and the third are of the Savartii group (Waters, 1905) and the second is one of the Costulae. Busk, 1859, classed Biflustra in the Escharidae; he introduced here Biflustra delicatula, which we know to be a synonym of Flusira savariii Savigny-Audouin, 1826.

Smitt, 1872, formed the family of Biflustridae for the reception of the genus Biflustra. "The quadrangular shape of the zooecia, as well as their strong, usually high, and hardly calcified and granular margins, in most cases will make the biflustridan type recognizable." He cites three species: Flustra lacroixii Savigny-Audouin, 1826, although under this name he figures Callopora flum Jullien, 1902; Biflustra denticulata, which is of very different structure (Hemiseptella); and Flustra savartii Savigny-Audouin, 1826.

As Biflustra has had no definite standing and as the paleontologists have described under that name a great number of species of very different structure, we created in 1917 the genus Acanthodesia for Flustra savartii in order to avoid all confusion. Biflustra is retained for narrow bifoliate Membranipores of doubtful affinities, but we can maintain Smitt's name for the family. In the absence of known larvae, we can not say if this family is a natural one.

\section{Genus ACANTHODESIA Canu and Bassler, 1920}

ACANTHODESIA SAVARTI Savigny-Audouin, 1826

Plate 1, Figures 5, 6; text Figure 1.

1920. Acanthodesia savarti CANU and BAssler, North American Early Tertiary Bryozoa. Bull. 106, U. S. National Museum, p. 100, pl. 21, figs. 2-4. (Bibliography and distribution.)

1923. Acanthodesia savarti $\mathrm{CANU}_{\mathrm{AN}}$ and BAssler, North American Later Tertiary and Quaternary Bryozoa. Bull. 125, U. S. National Museum, p. 31. (Study of the varieties.) 
Our specimens are bilamellar with undulated and twisted fronds. The serrate denticle is rare and there are no spicules. The opercular valve is thin, broad, transverse, in conformity with our drawings of specimens from the Philippines. In longitudinal sections there are two multiporous septulae. In transverse sections the zooecial walls are thick and have two large multiporous septulae.

Biology.-Our specimens were uncolored, but in the Philippine material we have found some of a brown-violet color. This is a species of shallow water (10 to 50 meters) generally.

Occurrence.-Albatross Station D. 2405, Gulf o Mexico; $28^{\circ} 45^{\prime} 00^{\prime \prime}$ N.; $85^{\circ} 02^{\prime}$ $00^{\prime \prime} \mathrm{W}$.; $30 \mathrm{fms}$; gray sand, broken coral.

Albatross Station D. 2380, Gulf of Mexico; $29^{\circ} 28^{\prime} 00^{\prime \prime}$ N.; $87^{\circ} 56^{\prime}$ $00^{\prime \prime} \mathrm{W} . ; 27$ fms.; gray sand, broken shells.

Tortugas, 16 meters (Osburn, 1914); Florida, 47 meters (Smitt). Plesiotype.-Cat. No. 7445, U.S.N.M.

\section{Genus CUPULADRIA Canu and Bassler, 1920}

CUPULADRIA CANARIENSIS Busk, 1852

- $\quad$ Plate 1, Figures 7-9; text Figure 2

1914. Cupularia guineensis OsBurn, The Bryozoa of the Tortugas Islands, Florida. Publication Carnegie Institution, Washington, No. 182, p. 194 (American bibliography).

1919. Cupuladria canariensis CANU and BAssler, Geology and Paleontology of the West Indies, Bryozoa. Publication Carnegie Institution, Washington, No. 291, p. 78, pl. 1, figs. 8-10. (Bibliography and geologic distribution.)

1923. Cupuladria canariensis CANU and BASSLER North American Later Tertiary and Quater. nary Bryozoa. Bull. 125, U. S. National Museum, p. 28, pl. 1, figs. 7-9.

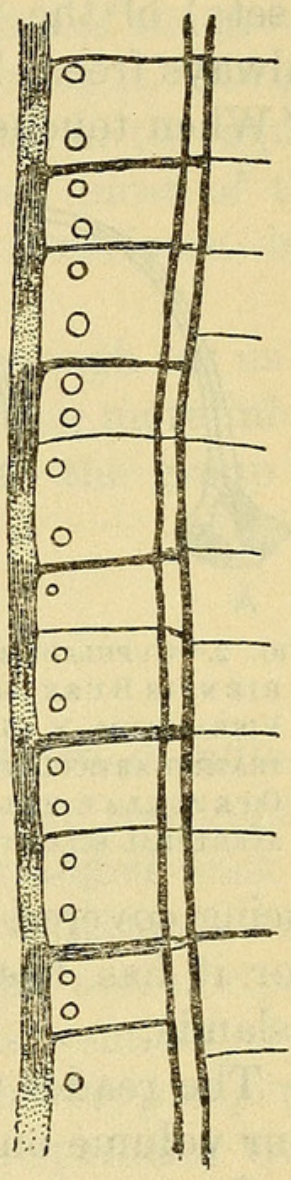

Fig. 1.-ACANTHODESIA SAVART I SAVIGNY AUDOUIN, 1826. LONGITUDINAL SECTION, $\times 85$, EXHIBITING THE TWO LATERAL SEPTULAE

Some hundreds of specimens, recent and fossil, have been examined and studied by us, and we find it still impossible to see any difference between Cupuladria canariensis and Cupuladria guineensis Busk, 1852.

The colonies are generally cupuliform, but some are conical; their diameter is quite variable. Each polygonal prism of the interior face is rectangular and is perforated by six rectangular pores. The latter are frequently four in number and sometimes only two; these variations can be observed on the same specimen. 
The opercular valve is somewhat higher than broad and little thickened. The seta of the vibraculum is falciform. When the ectocyst covers the interior face, the large pores appear by transparency much smaller and circular. This deceiving aspect enables one to suppose the existence of two species. The vibraculum belongs to the proximal zooecium.

Biology.-The calcite of our living specimens is white but their ectocyst is light colored. The color of Osburn's specimens is "horn brown, due mainly to the chitinous bristles which form the mandible (setr) of the vibracula." Our specimens, like those of Osburn, are always free. The following observation of Osburn is very important: "When touched the bristles stand erect for some time." It confirms

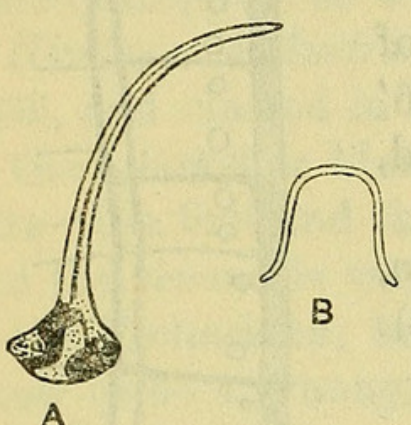

Fig. 2.-Cupuladria CANARIEN IS B USK, $1852 . \quad A$. VibracUlum, $X 85$, ILlUSTRATING ARTICULATION. $B$. OPERCULAR VALVEAND APERTURAL SCLERITE, $\times 85$ our views on the physiologic functions of the vibracula and of the setiform avicularia. These are organs of relation either with the surrounding medium or between the cells themselves.

This is an equatorial species which in the Mediterranean does not extend beyond the thirty-eighth parallel. Its presence in the Gulf of California indicates an old passageway between the Atlantic and the Pacific.

C. canariensis is one of the rare species characteristic of the abyssal deeps. The mobility of the colony is occasioned by the presence of numerous vibracula which permits them to escape being covered with mud. The bathymetric dispersion is very great, for it has been dredged on the sands of little depth at the Canary Islands.

The reader will find a detailed study of the genus Cupuladria in our volume on the Philippine bryozoa.

Occurrence.-Albatross Station D. 2405, Gulf of Mexico, $28^{\circ} 45^{\prime}$ $00^{\prime \prime} \mathrm{N}$.; $85^{\circ} 02^{\prime} 00^{\prime \prime} \mathrm{W}$.; $30 \mathrm{fms}$.; gray sand, broken coral.

Albatross Station D. 2639, Straits of Florida, $25^{\circ} 04^{\prime}$ $50^{\prime \prime} \mathrm{N}$.; $80^{\circ} 15^{\prime} 10^{\prime \prime} \mathrm{W}$.; $56 \mathrm{fms}$.; coral sand.

Atlantic, Fowey Light, 15 miles south of Miami, Fla.; $40 \mathrm{fms}$.

Tortugas, 16 meters (Osburn); Florida, 16-21 meters (Smitt).

Pliocene: Minnitimmi Creek, Bocas Island, Almirante Bay, Panama.

Plesiotypes.-Cat. No. 7829, U.S.N.M. 


\section{Genus QUADRICELLARIA D'Orbigny, 1851}

The zoarium is articulated by segments. The zooecia are membraniporoid and arranged on four faces (of which two are narrower) placed back to back. No ovicell.

Genotype.-Quadricellaria elegans D'Orbigny, 1851. Quadricellaria caraibica, new species here described, may be considered as a recent genotype.

Range.-Cretaceous (Turonian), Recent.

Affinities.-The discovery in the present seas of this old genus is very important; it shows the great vitality of the genera of the group Ascophora or of the Flustrines as the old authors wrote it. Originating as far back as the Cretaceous, they persist still in the equatorial zone of the recent seas. Jullien, 1881, classed most of the Cretaceous species of Quadricellaria in his genus Smittipora but D'Orbigny's name has priority.

The number of specimens obtained is not large enough for us to affirm definitely the absence of ovicells. While waiting more information, it appears best to introduce this genus into the group of Membraniporae without ovicell.

QUADRICELLARIA CARAIBICA, new species

\section{Plate 2, Figures 1-3}

Description.-The zoarium is bushy, radicelled, formed of numerous articulated, dichotomous branches; the segments are rectangular and formed of four longitudinal series of zooecia arranged back to back and of which two are wider. The zooecia are distinct, very long, subrectangular with a convex distal border; the mural rim is thin and little salient, complete. The opesium is semielliptical, very elongated, with a straight proximal border; the cryptocyst is shallow, flat, smooth, longer than the opesium. The opercular valve is small, entirely adjacent to the mural rim.

$$
\begin{array}{r}
\text { Measurements. - Large opesia }\left\{\begin{array}{l}
h_{0}=0.20 \mathrm{~mm} . \\
l_{0}=0.10 \mathrm{~mm} .
\end{array}\right. \\
\text { Large zooecia }\left\{\begin{array}{l}
L z=0.60 \mathrm{~mm} . \\
l_{z}=0.30 \mathrm{~mm} .
\end{array}\right.
\end{array}
$$

Structure.-The zooecium which terminates a segment and which bears the two new branches is very convex in its distal portion, which gives it the aspect of a false ovicell. The ectocyst covers all the zooecium and is terminated by the opercular valve, which is the constant structure in the Membraniporae. The cryptocyst is inclined toward the opesium, so that the mural rim enlarges into two small lateral facettes. All of our segments came from the same colony, which was without ovicells. 
This species corresponds rigorously to the genus Quadricellaria D'Orbigny, 1851. All the Cretaceous species, except one, described by this author have this structure. This discovery shows again that the study of the equatorial bryozoa is indispensable to the paleontologist.

Biology.-The ectocyst is not pigmented; its natural tint is light colored. We have observed some zooecia closed by a calcareous lamella perforated at the center. The collection of numerous specimens is necessary to study the complete structure of this important species.

Occurrence.-Albatross Station D. 2136, Caribbean Sea; $17^{\circ} 43^{\prime}$ $40^{\prime \prime}$ N.; $75^{\circ} 38^{\prime} 25^{\prime \prime}$ W.; 52 fms.; coral, broken shells.

Cotypes.-Cat. No. 7574 , U.S.N.M.

\section{Family ELECTRINIDAE D'Orbigny, 1851}

\section{Genus NITSCHEINA Canu, 1900}

Harmer ("Siboga," 1926) adopts Nichtina (Nitscheina) Canu, 1900, for the M. membranacea group in place of Membranipora which he retains for unplaced members of the Membraniporae. Although we have previously employed Membranipora as a valid genus, we now follow this eminent authority.

\section{NITSCHEINA MEMBRANACEA Linnaeus, 1766}

Plate 1, Figure 4

1914. Membranipora membranacea OsBurn, Bryozoa from the Tortugas Islands, Florida. Publication Carnegie Institution, Washington. No. 182, p. 193 (American bibliography).

This is an almost universal species and has been noted in the Temperate Zones of both hemispheres. Observed in California and in Alaska by Miss Robertson and recorded by Osburn at the Tortugas. It was unknown in South America until the Albatross dredged very beautiful specimens off Chili.

The species differs from Nitscheina (Membranipora) tuberculata Bosc, 1802 (= Membranipora tehuelca D'Orbigny, 1839), in its small tubercles which are vertical (not oblique) and never united together.

Occurrence.-Albatross Station D. 2782, off Chili, South America; $51^{\circ} 12^{\prime} 00^{\prime \prime}$ S.; $74^{\circ} 13^{\prime} 30^{\prime \prime} \mathrm{W}$.; $258 \mathrm{fms}$.; blue mud.

Plesiotype.-Cat. No. 7548, U.S.N.M.

\section{NITSCHEINA TUBERCULATA Bosc, 1802}

1914. Membranipora tehuelca OsBuRn, The Bryozoa of the Tortugas Islands, Florida. Publication Carnegie Institution, Washington. No. 182, p. 193. (American bibliography.)

1921. Membranipora tehuelca Robertson, Bryozoa from the Bay of Bengal. Records of the Indian Museum, vol. 22, p. 47. 
1922. Membranipora tuberculata Marcus, Südafrikanische Bryozoen aus der Sammlung des Gothenburger Museum. Küngl Vetenskaps och Vitterhets Samhalles Handlingar, vol. 25, p. 15, fig. 8 .

1923. Membranipora tuberculata CANU and BAssler, North American Later Tertiary and Quaternary Bryozoa. Bull. 125, U. S. National Museum, p. 22, pl. 33, figs. 3-5. (Bibliography and distribution.)

Marcus has erroneously placed in the synonymy of this species Biflustra denticulata Smitt, 1872, which is quite a different species belonging to the genus Hemiseptella.

The present species is very fragile and in drying, the zooecia become greatly deformed. The development of tubercles is very irregular even on the same specimen, as is apparent in one of our figures of 1923.

Biology.-It was believed formerly that this species was confined to the American Continent but the discoveries of Marcus showed that it had traveled around Africa and had extended into the Indian Ocean, where Miss Robertson noted it, and also into the western Pacific, where we have observed it in the Philippines. This is then a universal species, quite cosmopolitan, transported on algae by the great marine currents. In the Northern Hemisphere it does not pass beyond the fiftieth parallel.

Occurrence.-Albatross Station D. 2647. Straits of Florida, $25^{\circ}$ $48^{\prime} 00^{\prime \prime} \mathrm{N}$.; $80^{\circ} 04^{\prime} 00^{\prime \prime} \mathrm{W}$.; $85 \mathrm{fms}$; gray sand, foraminifera.

Atlantic: Straits of Florida; Tortugas (Osburn); Bermuda (Verrill).

Geographic distribution.-Pleistocene of California. South Africa (Marcus); Philippines.

Cat. No. 7549 , U.S.N.M.

\section{Family FLUSTRIDAE Smitt, 1867}

\section{Genus FLUSTRA Linnaeus, 1761}

FLUSTRA (CARBASEA) CAPITATA, new species

Plate 28, Figures 4, 5

Description.-The zoarium is free, unilamellar, formed of narrow fronds with five longitudinal series of zooecia. The zooecia are distinct, separated by a common salient thread, elongated, somewhat lozenge-shaped. The mural rim is thin and the opesium entire. The opercular valve is adjacent to the mural rim and its border is much chitinized. The ovicell is very large, endozooecial, very convex; the ectooecium is incompletely calcified and leaves a circular area on which an avicularium is sometimes placed. The avicularium is distal, oblique, always adjacent to the mural rim; the beak is oriented toward the aperture; the mandible is semicircular. 
Measurements.-Opercular valve: $l_{0}=0.30 \mathrm{~mm}$.

$$
\text { Zooecium }\left\{\begin{array}{l}
L z=0.90-1.00 \mathrm{~mm} . \\
l_{z}=0.35-0.40 \mathrm{~mm} .
\end{array}\right.
$$

Affinities.-The ovicelled zooecia have the larger dimensions; the mural rim bears a pair of spines. This species is well characterized by its large ovicell.

Occurrence.-Albatross Station D. 2750, off Chili, South America; $18^{\circ} 30^{\prime} \mathrm{N}$.; $63^{\circ} 31^{\prime} \mathrm{W}$.; $496 \mathrm{fms}$.; fine gray sand.

Cotypes.-Cat. No. 7499, U.S.N.M.

\section{Family HINCKSINIDAE Canu and Bassler, 1927}

\section{Genus APLOUSINA Canu and Bassler, 1927}

Membraniporae with endozooecial ovicell; no spines, no avicularium, and no dietellae.

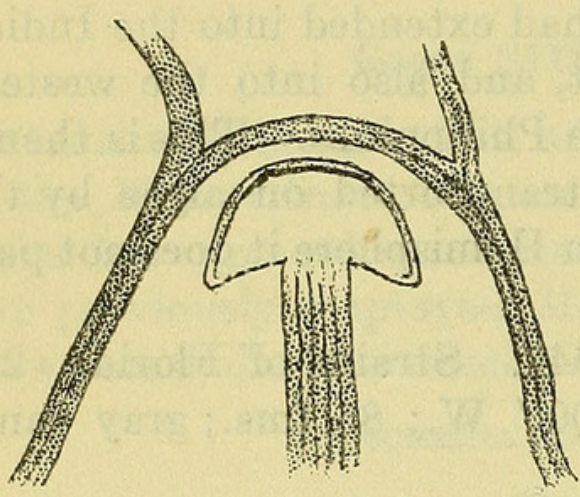

Fig. 3.-Aplousina gigantea Canu and BASSIER, 1927 DIAGRAMMATIC DRAWING OF A ZOOECIUM, $X 85$, SHOWING THE TENTACULAR SHEATH ATTACHED TO THE OPERCUlar VALVE. THIS IS FIXED TO AN EXTERIOR THICKENING OF THE ECTOCYST
Genotype.-Aplousina gigantea Canu and Bassler, 1927.

Range.-Miocene-Recent.

\section{Aplousina Gigantea Canu and Bassler, 1927}

Plate 2, Figure 6, text Figure 3

1927. Aplousina gigantea $\mathrm{CANU}_{\mathrm{AN}}$ and BAsSLER, Classification Cheilostomatous Bryozoa. Proc. U. S. Nat. Mus., vol. 69, p. 3, pl. 1, fig. 1.

Description. The zoarium encrusts shells. The zooecia are very large, lozenge-shaped, not separated from each other; the mural rim is very thin, filiform. The opercular valve is large, transverse, semilliptical and removed

from the distal border of the zooecium. The ovicell is very small, transverse, little salient, ornamented with a small frontal callosity.

Measurements.-Opercular valve $\left\{\begin{array}{l}h o=0.12 \mathrm{~mm} \text {. } \\ l_{0}=0.18 \mathrm{~mm} \text {. }\end{array}\right.$

$$
\text { Zooecia }\left\{\begin{array}{l}
L z=0.84-0.90 \mathrm{~mm} . \\
l z=0.60-0.64 \mathrm{~mm} .
\end{array}\right.
$$

Structure.-The tentacular sheath is attached to the sclerite which borders the opercular valve. The length of the tentacles is half that of the zooecia. The parietal muscles are numerous. This species is larger than the Miocene species, $A$. (Membrendvecium) grandis, Canu and Bassler, 1923.

Biology.-We have observed this beautiful species only on the coast of Florida, where it appears abundant. It was in reproduction March 15, 1885, and April 9, 1886. Its large dimensions, the tenuity of its tentacles, and the absence of avicularia indicate that it lived especially in localities where a marine current incessantly renewed the plancton. 
Occurrence.-Albatross Station D. 2405, Gulf of Mexico; $28^{\circ} 45^{\prime}$ $00^{\prime \prime} \mathrm{N}$.; $85^{\circ} 02^{\prime} 00^{\prime \prime} \mathrm{W}$.; 30 fms.; gray sand, broken coral,

Albatross Station D. 2639, Straits of Florida; $25^{\circ} 04^{\prime}$ $50^{\prime \prime} \mathrm{N}$.; $80^{\circ} 15^{\prime} 10^{\prime \prime} \mathrm{W}$.; 56 fms.; coral sand.

Holotype.-Cat. No. 7452, U.S.N.M.

APLOUSINA TUBEROSA, new species.

Plate 2, Figures 4, 5

Description.-The zoarium encrusts shells, serpulae and especially Steganoporella magnilabris. The zooecia are large, distinct, separated by a furrow, elliptical; the proximal gymnocyst is very small; the mural rim is very thin, flat, granulated, with smooth termen. The opesium is very large and of the form of the zooecia. The ovicell is very small, transverse, little convex, always accompanied by two lateral tuberosities.

$$
\text { Measurements.-Opesia }\left\{\begin{array}{l}
h_{o}=0.50 \mathrm{~mm} \\
l_{0}=0.32 \mathrm{~mm}
\end{array}\right.
$$

$$
\text { Zooecia }\left\{\begin{array}{l}
L z=0.60 \mathrm{~mm} \\
l z=0.40 \mathrm{~mm} .
\end{array}\right.
$$

Variations. - The micrometric measurements vary from single to double even on the same specimen. The zooecia which begin a series are deformed and oval.

Afinities.-This species differs from Callopora filum Jullien, 1903, in its endozooecial ovicell, in its mural rim enlarged at the base and in which the termen is smooth.

Biology.-This is a magnificent species of the shelly bottoms. It was in reproduction (ovicelled) May 1, 1884, and March 15, 1885. The colony and the ectocyst are light colored like the substratum. It lived as a true parasite on Steganoporella magnilabris; the movement of the gigantic opercula of this species does not trouble it and it even impedes them by its rapid development.

We have observed several cases of total regeneration. The species did not cross the Tropics and did not penetrate into the Caribbean Sea. However, we can consider as tropical all the Gulf of Mexico faunas because of the special location of the Gulf.

Occurrence.-Albatross Station D. 2169 , off Habana, Cuba; $23^{\circ} 10^{\prime}$ $28^{\prime \prime} \mathrm{N}$.; $82^{\circ} 20^{\prime} 27^{\prime \prime} \mathrm{W}$.; $78 \mathrm{fms}$.; coral.

Albatross Station D. 2317 , north of Cuba; $24^{\circ} 25^{\prime}$ $45^{\prime \prime} \mathrm{N}$.; $81^{\circ} 46^{\prime} 45^{\prime \prime} \mathrm{W}$.; 45 fms.; coral.

Albatross Station D. 2365 , east of Yucatan; $22^{\circ} 18^{\prime}$ $00^{\prime \prime} \mathrm{N}$.; $87^{\circ} 04^{\prime} 00^{\prime \prime} \mathrm{W}$.; $24 \mathrm{fms}$.; white rock, coral. Albatross Station D. 2405, Gulf of Mexico; $28^{\circ} 45^{\prime}$ $00^{\prime \prime}$ N.; $85^{\circ} 02^{\prime} 00^{\prime \prime} \mathrm{W}$.; $30 \mathrm{fms}$.; gray sand, broken coral.

Albatross Station D. 2639, Straits of Florida; $25^{\circ} 04^{\prime}$ $50^{\prime \prime} \mathrm{N}$.; $80^{\circ} 15^{\prime} 10^{\prime \prime} \mathrm{W}$.; $56 \mathrm{fms}$.; coral sand.

Cotypes.-Cat. Nos. 7453,7454 , U.S.N.M. 


\section{Genus HINCKSINA Norman, 1903}

HINCKSINA PERIPOROSA, new species

Plate 2, Figures 8-11

Description.-The zoarium encrusts bryozoa, corals, nullipores, hydroids, and shells. The zooecia are distinct, separated by a deep furrow, surrounded by a line of interjunctural pores, oval; the gymnocyst is small, convex; the mural rim is very thin and bears 16-18 spicules. The opesium has the form of the zooecium. The ovicell is very small, a little convex, transverse. There are pyriform zooeciules between the zooecia; their appearance is sporadic.

$$
\begin{array}{r}
\text { Measurements.-Opesium }\left\{\begin{array}{l}
h_{o}=0.45 \mathrm{~mm} . \\
l_{0}=0.20-0.25 \mathrm{~mm} .
\end{array}\right. \\
\text { Zooecia }\left\{\begin{array}{l}
L_{z}=0.60-0.65 \mathrm{~mm} . \\
l_{z}=0.30-0.32 \mathrm{~mm} .
\end{array}\right.
\end{array}
$$

Structure.-The interjunctural pores are covered by the ectocyst. Their significance is unknown; they appear to result from an incomplete calcification. These pores do not furnish a generic character for they are found also in Callopora circumclathrata Hincks, 1881, in Cauloramphus disjunctus, new species from the Philippines, in Hincksina multispinata Canu and Bassler, 1923, and in Mystriopora (?) areolata Canu and Bassler, 1923, both from the California Pleistocene. The zooeciules are always very small and pyriform. Their sporadic arrangement indicates a zoarial function.

Affinities.-This species differs from Hincksina multispinata in the much larger micrometric measurements and in the presence of larger and less numerous pores. It differs from Mystriopora (?) areolata in the smaller micrometric measurements. It much resembles Electra di stefanoi Cipolla, 1920, from the Sicilian Pliocene and if the author had figured the ovicell we might have made this identification.

Biology.-We have observed several cases of total regeneration. The figured ancestrula is surrounded by zooecia closed by a perforated calcareous membrane and with regenerated zooecia. Some of the regenerated zooecia are formed by a zooeciule replacing an ordinary zooecium. The larva is very active and affixes itself on all marine objects, but principally on the animals with carapace, living or dead. It is thus a parasite of Steganoporella magnilabris. Its large bathymetric extension has no connection with its geographic distribution; it is probable that it will be found in many other localities. Almost all of our specimens were dead; the only living ones were in reproduction March 15, 1885. 
Occurrence.-Albatross Station D. 2167, off Habana, Cuba; $23^{\circ} 10^{\prime}$ $40^{\prime \prime}$. N.; $82^{\circ} 20^{\prime} 30^{\prime \prime}$ W.; 201 fms.; coral.

Albatross Station D. 2319 , north of Cuba; $23^{\circ} 10^{\prime}$ $37^{\prime \prime} \mathrm{N}$.; $82^{\circ} 20^{\prime} 06^{\prime \prime} \mathrm{W}$.; $143 \mathrm{fms}$.; gray coral.

Albatross Station D. 2405, Gulf of Mexico; $28^{\circ} 45^{\prime}$ $00^{\prime \prime} \mathrm{N}$.; $85^{\circ} 02^{\prime} 00^{\prime \prime} \mathrm{W}$.; 30 fms.; gray sand, broken coral.

Albatross Station D. 2639, Straits of Florida; $25^{\circ} 04^{\prime}$ $50^{\prime \prime} \mathrm{N}$.; $80^{\circ} 15^{\prime} 10^{\prime \prime} \mathrm{W}$.; 56 fms.; coral sand.

Cotypes.-Cat. No. 7519, U.S.N.M.

\section{Genus MEMBRENDOECIUM Canu and Bassler, 1917}

MEMBRENDOECIUM STRICTOROSTRIS, new species

Plate 2, Figure 7

Description.-The zoarium encrusts nullipores and dead shells. The zooecia are distinct, separated by a deep furrow, a little elongated, oval, ornamented frequently by a convex gymnocyst. The opesium is oval, the point at the top; the mural rim is thick, beveled, enlarged at the base. The ovicell is small, endozooecial, convex, transverse. In the interzooecial angles there is a small avicularium, long, very narrow, acuminated.

Measurements.-Opesium $\left\{\begin{array}{l}h o=0.30-0.35 \mathrm{~mm} . \\ l_{0}=0.20-0.25 \mathrm{~mm} \text {. }\end{array}\right.$

Zooecia $\left\{\begin{array}{l}L z=0.45-0.60 \mathrm{~mm} \\ l_{z}=0.30-0.40 \mathrm{~mm} .\end{array}\right.$

Affinities.-The micrometric measurements are quite variable, ranging from one to twice the size and have only an approximate value. The gymnocyst is frequent but in no wise constant and entire colonies are deprived of it. There are cases of total regeneration.

The species differs from Membrendoecium ovatum of the Philippines in its long, narrow avicularia. It differs from Membrendoecium savarti MacGillivray, 1895, in its mural rim much less enlarged at the base. We have described five fossil species from the Eocene and one from the Miocene of America, so that the genus has therefore persisted in the same region since the Claibornian.

The species was in reproduction and fixation January 17, 1885.

Occurrence.-Albatross Station D. 2319, north of Cuba; $23^{\circ} 10^{\prime}$ $37^{\prime \prime} \mathrm{N}$.; $82^{\circ} 20^{\prime} 06^{\prime \prime} \mathrm{W}$.; $143 \mathrm{fms}$; gray coral.

Holotype.-Cat. No. 7552, U.S.N.M.

\section{Genus VIBRACELLINA Canu and Bassler, 1917}

VIBRACELLINA LAXIBASIS, new species

Plate 32, Figure 2

Description.-The zoarium encrusts very small globular pebbles. The zooecia are distinct, separated by a deep furrow, small, some- 
what elongated, oval, sometimes ornamented with a very short gymnocyst. The mural rim is thin, salient. Its interior part is finely granular and slightly enlarged on the sides and at the base; the termen is sharp. The opesium is oval and very finely denticulated. The vibraculum is small, elliptical, auriculated. The ovicell is endozooecial and very small.

$$
\begin{array}{r}
\text { Measurements.-Opesium }\left\{\begin{array}{l}
h_{0}=0.20 \mathrm{~mm} . \\
l_{o}=0.12-0.16 \mathrm{~mm} .
\end{array}\right. \\
\text { Zooecia }\left\{\begin{array}{l}
L_{z}=0.36 \mathrm{~mm} . \\
l_{z}=0.24 \mathrm{~mm} .
\end{array}\right.
\end{array}
$$

Variations.-On the rather small substratum the cells are necessarily irregular and of variable dimensions. The ancestrula is surrounded either by five cells and a vibraculum or by six cells and a vibraculum, but they do not at all appear to result from budding of this ancestrula. It is, moreover, difficult to trace the zooecial axes on the convex specimens.

Affinities.-This species is smaller than Vibracellina viator and $V$. crassatina of the Philippines and V. capillaria Canu and Bassler, 1920. It is, on the contrary, larger than Vibracellina pusilla Canu and Bassler, 1923, from the Pliocene of Florida. Its affinities are rather vith Vibracellina simplex Canu and Bassler, 1923, from the Miocene of Florida, but differs in its broader and more decorated mural rim and in its denticulated opesium.

Occurrence.-Pliocene: Minnitimmi Creek, Bocas Island, Almirante Bay, Panama.

Cotypes.-Cat. No. 70868, U.S.N.M.

\section{Genus ANTROPORA Norman, 1903}

\section{ANTROPORA PUSTULATA, new species}

Plate 3, Figure 11; Plate 16, Figure 12

Description.-The zoarium encrusts corals and fragments of shells. The zooecia are distinct, separated by a furrow, elongated pyriform; the gymnocyst is smooth, convex; the mural rim is little salient, thin, pyriform; the cryptocyst is concave, smooth. The opesium is elliptical, marginated, finely crenulated, ornamented with a distal, oblique lamella, serving as a border to the deep opesium. The ovicell is hyperstomial, independent of the distal zooecium. The mural rim bears exteriorily four to six small hollow spines and two oblique triangular avicularia. Irregular zooeciules, perforated, in the form of small pustules, are arranged sporadically between the zooecia.

$$
\begin{aligned}
\text { Measurements.-Opesium }\left\{\begin{array}{l}
h h_{o}=0.25 \mathrm{~mm} . \\
l_{o}=0.14 \mathrm{~mm} .
\end{array}\right. \\
\text { Zooecia }\left\{\begin{array}{l}
L z=0.50-0.75 \mathrm{~mm} . \\
l_{z}=0.35-0.45 \mathrm{~mm} .
\end{array}\right.
\end{aligned}
$$


Structure.-The gymnocyst is much developed, contrary to that observed in Antropora granulifera Hincks, 1880. It is broad, convex, and smooth.

There are two opesia with the same proximal border. The external (superior) opesium is elliptical, elongated, a little narrowed on the transversal axis; its distal border is confused with that of the mural rim. The inner opesium is subcircular, submedian; its distal border is visible at the bottom of the cell. The cryptocyst entirely surrounds the inner opesium, but the proximal portion between the two opesia forms a concavity more or less deep, which continues below the mural rim and forms a kind of endozooecial ovicell. We suppose that the opercular muscles are lodged in this distal concavity.

The hypostege is deep and perfected. It is regularly arranged between the mural rim and the salient, crenulated thread which surrounds the proximal half of the opesium.

The avicularia are constant and zooecial; they are apparently indispensable for the movements of the opercular valve, but we can not understand what might be the action of their minute mandible.

The perforated kenozooecia arranged sporadically between the cells are covered and closed by the ectocyst.

Total regeneration is revealed by a double mural rim.

Afinities.-This species differs from Antropora granulifera Hincks, 1880 , in the presence of a large gymnocyst and of six small distal spines, in its less oblique avicularia, in its smooth cryptocyst, and in its sporadic kenozooecia.

Harmer, 1926, discovered that the ovicells of Antropora granulifera are endozooecial. Here they are clearly hyperstomial but closed by the operculum. This important difference between the two species is inexplicable to us.

Biology.-This species appears to live in deep waters. It was ovicelled in May, 1884. Corals form the preferred substratum.

Occurrence.-Albatross Station D. 2321, Gulf of Mexico, north of Cuba; $23^{\circ} 10^{\prime} 54^{\prime \prime}$ N.; $82^{\circ} 18^{\prime} 00^{\prime \prime}$ W.; 230 fms. Albatross Station D. 2167, Gulf of Mexico, off Habana; $23^{\circ} 10^{\prime} 40^{\prime \prime} \mathrm{N}$.; $82^{\circ} 20^{\prime} 30^{\prime \prime} \mathrm{W}$.; $201 \mathrm{fms}$.

Cotypes.-Cat. No. 7456 , U.S.N.M.

\section{Family -FARCIMINA*RIIDAE Busk, 1884}

\section{Genus LEVINSENELLA Harmer, 1926}

The ovicells are strongly prominent. The zooecia are without spinous processes; the distal wall has a number of scattered uniporous septulae. The avicularia are capitate, attached to the distal 
wall at their proximal part and firmly fixed with their basal wall to the frontal membrane of the distal zooecium. The colonies are not jointed. (Levinsen, 1909.)

This genus differs from Farciminaria Busk, 1852, in the presence of a distal avicularium and in the square section of the branches.

Genotype.-Levinsenella (Columnaria) borealis Levinsen, 1909.

\section{LEVINSENELLA BRASILIENSIS Busk, 1884}

\section{Plate 1, Figure 3; text Figure 4}

1884. Farciminaria brasiliensis Busk, Polyzoa collected by Challenger. Scientific Results Voyage Challenger, vol. 10, pt. 30, p. 50, pl. 31, fig. 2.

Our specimens are very close to Busk's species and differ only in the avicularia, in which the mandible is perpendicular and not par-

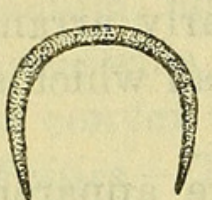

Fig. 4.-Levinsenella BRASILIENSIS B U S K, 1884. OPERCULAR VALVE AND APERTURA, $X 85$, EACH BORDERED BY A SCLERITE allel to the zooecial plane. They were living and ovicelled January 27, 1884.

The opercular valve is absolutely analogous to that in the Flustridae and the Membraniporae.

Occurrence.-D. 2117, Caribbean Sea; $15^{\circ} 24^{\prime}$ $40^{\prime \prime} \mathrm{N}$.; $63^{\circ} 31^{\prime} 30^{\prime \prime} \mathrm{W}$.; $683 \mathrm{fms}$.; yellow mud, fine sand.

Atlantic: North of Bahia, South America, 648 meters.

Plesiotypes.-Cat. No. 7477, U.S.N.M.

\section{Genus NELLIA Busk, 1852}

\section{NELLIA OCULATA Busk, 1852}

1873. Nellia oculata Smitr, Floridan Bryozoa, pt. 2. Kongl. Svenska Vetenskaps-Akademiens Handlingar, vol. 11, No. 4, p. 3, pl. 11, figs. 53, 54.

1914. Nellia oculata Osburn, The Bryozoa of the Tortugas Islands, Florida. Publication Carnegie Institution, Washington. No. 182, p. 191 (American bibliography).

1920. Nellia oculata $\mathrm{CANU}_{\mathrm{AN}}$ and BASsler, North American Early Tertiary Bryozoa. Bull. 106, U. S. National Museum, p. 196, pl. 82, figs. 6-10. (Supplementary bibliography.)

1922. Nellia oculata Marcus, Bryozoen von den Aru-Inseln. Abhandl. Senckenb. Naturf. Gesellschaft, vol. 35, p. 423.

1923. Nellia oculata CANU and BAssler, North American Later Tertiary and Quaternary Bryozoa. Bull. 125, U. S. National Museum, p. 55 , pl. 2 , figs. $5-7$.

Measurements.-Opercular valve $\left\{\begin{array}{l}h_{0}=0.06-0.10 \mathrm{~mm} . \\ l_{0}=0.08-0.10 \mathrm{~mm} .\end{array}\right.$

Zooecia $\left\{\begin{array}{l}L_{z}=0.50-0.54 \mathrm{~mm} . \\ l_{z}=0.26 \mathrm{~mm} .\end{array}\right.$

Diameter of branches, $0.30 \mathrm{~mm}$. 
The colonies are attached to sponges and occasionally to shells (Osburn). The radical tubes spring out from the middle of the front side just below the apertural area of the zooecia (Smitt).

Occurrence.-Albatross Station D. 2405, Gulf of Mexico; $28^{\circ} 45^{\prime}$ $00^{\prime \prime} \mathrm{N}$.; $85^{\circ} 02^{\prime} 00^{\prime \prime} \mathrm{W}$.; $30 \mathrm{fms}$.; gray sand, broken coral.

Albatross Station D. 2407, Gulf of Mexico; $28^{\circ} 47^{\prime}$ $30^{\prime \prime} \mathrm{N}$.; $84^{\circ} 37^{\prime} 00^{\prime \prime} \mathrm{W}$.; 24 fms.; coral, broken shells.

Florida, 21-222 meters (Smitt); Tortugas, 16-29 meters (Osburn); Texas and St. Thomas, West Indies (Levinson).

Pliocene: Minnitimmi Creek, Bocas Island, Almirante Bay, Panama.

Geographic distribution.-Pacific: Torres Strait, Bass Strait, Queensland, Victoria, Cape Grenville, Cape Joubert (23 meters), Gasparstrasse (29 meters), Philippines, Heard Island, and Crozet Island. Indian Ocean: Mergui Archipelago, Gulf of Arabia, Ceylon, Sudanese Red Sea, Zanzibar, Wasin. Atlantic: Bahia, Brazil.

Geologic distribution.-Eocene (Lutetian) of the Paris Basin (Canu); Oligocene (Vicksburgian) of Alabama and Mississippi (Canu and Bassler); Miocene (Burdigalian) Cercado de Mao, Santo Domingo (Canu and Bassler); Miocene (Helvetian) of Touraine and Egypt (Canu); Miocene of Australia (MacGillivray).

\section{Family ALDERINIDAE Canu and Bassler, 1927}

This family was proposed for all the Membraniporae in which the ovicell is hyperstomial. It comprises, therefore, groups 3 and 4 of our classification of 1920 . It is probable that certain articulated genera will some day be classed in this family, but their larval system not being known, it is preferable to leave them where their authors have placed them. There are also some exceptions to make regarding the genus Amphiblestrum, of which the anatomy is absolutely unknown; some species belong perhaps to the Opesiulidae.

\section{Genus ALDERINA Norman, 1903}

ALDERINA IRREGULARIS Smitt, 1873

Plate 3, Figure 3; Plate 32, Figure 4

1873. Membranipora irregularis SмıтT, Floridan Bryozoa. Kongl. Svenska Vetenskaps-Akademiens Handlingar, vol. 11, p. 8, pl. 11, fig. 63.

1914. Membranipora irregularis OsBurn, The Bryozoa of the Tortugas Islands, Florida. Publication Carnegie Institution, Washington, No. 182 , p. 194.

1920. Alderina irregularis $\mathrm{C}_{\mathrm{ANU}}$ and BAsslen, North American Early Tertiary Bryozoa. Bull. 106, U. S. National Museum, p. 142. (Not D'Orbigny, 1839, Waters, 1904, Busk, 1861, Manzoni, 1875.) 
Measurements.-Opesium $\left\{\begin{array}{l}h_{0}=0.36 \mathrm{~mm} . \\ l_{0}=0.24 \mathrm{~mm} .\end{array}\right.$

$$
\text { Zooecia }\left\{\begin{array}{l}
L_{z}=0.48-0.50 \mathrm{~mm} . \\
l_{z}=0.36 \mathrm{~mm} .
\end{array}\right.
$$

Structure.-The micrometric measurements shown on our specimens differ very little from those which we published in 1922 .

"The ovicell is transverse and formed by two calcified layers; the superior one is very finely granulated, incomplete, surrounding an area which is irregular and more or less linear. It is hyperstomial and opens by a large special orifice which the opercular valve never closes. The latter is bordered by a very thick sclerite. The mural rim is granular and enlarged at the base." (Canu and Bassler, 1920.)

"The granulation of the border varies with the amount of calcification. Ooecia are present. In younger stages these are quite prominent, but with latter calcification they become included in the general crust." (Osburn, 1914.)

Our specimens encrust shells, nullipores, and débris.

Affinities.-This species is the equatorial representative of the northern Alderina imbellis Hincks, 1860 , but differs from it in its transverse and nonelongated ovicell and its irregularly linear and nonrectangular ovicellarian area.

Under the name of Membranipora irregularis the authors have confused several species, and we gave the history of them in 1920 . The bibliography is only that which we indicate above because this species was with certainty dredged only in the Gulf of Mexico.

Occurrence.-Albatross Station D. 2319, north of Cuba; $23^{\circ} 10^{\prime}$ $37^{\prime \prime}$ N.; $82^{\circ} 20^{\prime} 06^{\prime \prime} \mathrm{W}$.; 143 fms.; gray coral.

Albatross Station D. 2405, Gulf of Mexico; $28^{\circ} 45^{\prime}$ $00^{\prime \prime}$ N.; $85^{\circ} 02^{\prime} 00^{\prime \prime} \mathrm{W}$.; 30 fms.; gray sand, broken coral.

Albatross Station D. 2639, straits of Florida; 56 fms.; coral sand.

Pliocene: Minnitimmi Creek, Bocas Island, Almirante Bay, Panama.

Plesiotypes.-Cat. Nos. 7451, 70831, U.S.N.M.

ALDERINA (?) PYRIFORMIS, new species

Plate 32, Figure 3

Description.-The zoarium is unilamellar. The zooecia are distinct, separated by a deep furrow, elongated, pyriform, ornamented sometimes with a short gymnocyst; the mural rim is salient, very thin superiorly, enlarged at the base, with a sharp termen. There are six distal spines placed on the exterior part of the mural rim and often a pair of lateral spines. The ovicell is hyperstomial, salient, 
globular, transverse; it is formed by two calcareous pellicules of which the superior is incomplete and leaves a large frontal cicatrix.

Measurements.-Opesium $\left\{\begin{array}{l}h_{0}=0.35-0.37 \mathrm{~mm} . \\ l_{0}=0.20-0.32 \mathrm{~mm} .\end{array}\right.$

$$
\text { Zooecia }\left\{\begin{array}{l}
L z=0.60-0.70 \mathrm{~mm} \\
l z=0.30-0.35 \mathrm{~mm} .
\end{array}\right.
$$

Affnities.-This new species differs from Alderina cesticella Canu and Bassler, 1923, in its much larger zooecia and in the number of its spines. The primoserial zooecia arise always from a lateral bud of a zooecium, a very frequent phenomenon in the Membranipores. There are, however, some species (Acanthodesia) where the budding is always distal. The nature of budding has not been sufficiently studied by the zoologists, and it may perhaps furnish excellent generic or specific characters. Our unique specimen does not bear avicularia.

Occurrence.-Pliocene: Minnitimmi Creek, Bocas Island, Almirante Bay, Panama.

Holotype.-Cat. No. 70832, U.S.N.M.

\section{Genus GEPHYROTES Norman, 1903}

1920. Gephyrotes CANu and Bassler, North American Early Tertiary Bryozoa. Bull. 106, U. S. National Museum, p. 300.

In introducing this genus into our nomenclature of 1920 we considered especially the spiramen which we thought corresponded to a special function $^{6}$. Also all the species do not have the same frontal structure; often it is totally different from that of the genotype; in Gephyrotes spinosa it is identical with that in Acanihocella. If this genus is indeed natural, it will be proof once more that the aspect of the frontal can not furnish generic characters since it results simply from the ordinary variations of the primitive spines. If we are deceived in our views, it is necessary to range the species with dietellae in Cribrilina as Levinsen thought in 1909; but the conclusion remains the same for Cribrilina.

Lang, 1922, gave the greatest importance to the form and the arrangement of the costules. This is not our view, for the exterior ornamentation can not serve to establish a natural classification.

GEPHYROTES SPINOSUM, new species

Plate 4, Figure 11

Description.-The zoarium encrusts stones. The zooecia are distinct, separated by a furrow, elliptical, a little elongated; the frontal is convex; the costules, 16 to 18 in number, are narrow, a little distinct, arranged transversely; they are separated by two or three very small

\footnotetext{
${ }^{6}$ Moreover, we consider that the absence of dietellae is still an important difference from the group Membraniporella-Cribrilina,
} 
lacunae; they bear two or three very salient lumen pores which give the frontal a spinous aspect. The frontal is terminated distally by a wide, smooth convex mucro; it forms with the wide apertural arch a kind of broad oblique peristome surrounding a kind of spiramen; the latter is itself protected in front by a small more or less salient tongue. The aperture is buried by the characteristic arch; the peristome is thin and bears on each side of the aperture a large, short, hollow spine, and distally two broad, claviform, bifid spines, often joined together to form a small special tongue.

$$
\text { Measurements.-Zooecia }\left\{\begin{array}{l}
L z=0.45-0.50 \mathrm{~mm} . \\
l_{z}=0.25-0.30 \mathrm{~mm} .
\end{array}\right.
$$

Structure.-This species is quite original and well characterized by its spinous costules. The apertural arch is very constant; the spiramen could correspond to a special function like that of the Galeopsidae and indispensable to the zooecial life.

The lacunae are so small that they must be subject to the phenomena of capillarity, of which it will be necessary to make a special study.

The apertural arch is altogether distinct from what we have observed in Cribrilina lineata and which is formed by the junction of two wide oral spines. Here it forms an integral part of the oral mucro and constitutes with it a true special armature in which the spiramen is perforated.

The arrangement of the costules is totally different from that of the genotype, Gephyrotes nitido-punctata Smitt, 1868. Their structure is that of Acanthocella.

The two large lateral spines observed on each side of the aperture are perhaps in reality very small pedunculato avicularia corresponding to the oral avicularia noted in almost all the species of the genus. Our rare specimens did not bear a single ovicell.

Occurrence.-Albatross Station D. 2319, north of Cuba; $23^{\circ} 10^{\prime}$ $37^{\prime \prime} \mathrm{N}$.; $82^{\circ} 20^{\prime} 06^{\prime \prime} \mathrm{W}$.; 143 ims.; gray coral. Albatross Station D. 2639, Straits of Florida; $25^{\circ} 04^{\prime}$ $50^{\prime \prime} \mathrm{N}$.; $80^{\circ} 15^{\prime} 10^{\prime \prime} \mathrm{W}$.; $56 \mathrm{fms}$; coral sand.

Holotype.-Cat. No. 7508 , U.S.N.M.

\section{Genus MARSSONOPORA Lang, 1914}

\section{MARSSONOPORA UNCIFERA, new species}

Plate 3, Figures 1, 2

Description.-The zoarium encrusts shells. The zooecia are arranged in linear series; they are oval, elongated, and united with each other by filiform zooeciules with very small orifice and arranged in the form of stolons. The opesium is oval; the mural rim is thin and bears a dozen spines in the form of claws. The ovicell is hyperstomial, globular, salient, always closed by the operculum. 
Structure.-Lang, 1914, considered the orifices placed on the caudal portion of the zooecia as avicularia. We have seen no mandibles on our living specimens, and the orifices observed are indeed the apertures of successive zooeciules forming the caudal portion of the zooecia. The zooeciules form thus true stolons of variable length which are not necessarily terminated by a zooecium. Our Figure 1 shows this phenomenon as perfect evidence. In their form these zooeciules are related to those of Trypostega; however, the latter are always isolated and in direct connection with the proximal zooecium. It is probable that these zooeciules are deprived of polypides. They differ from true stolons of Ctenostomata in the presence of an orifice.

The figure of Lang seems to indicate that the ovicell is closed by a special operculum as in Callopora, but his species is a fossil one, and we know how difficult it is to determine by the examination of the skeleton alone the relation of the operculum and the ovicell. In our specimens without any doubt the operculum closes the ovicell. In spite of this divergence, we do not believe we ought to create a new genus for the stoloniferous Membranipores, for it is preferable to attribute to the fossils the characters of the recent species.

Biology.-Our specimens from locality D. 2167 were alive when dredged. They were in reproduction May 1, 1884.

Occurrence.-Albatross Station D. 2167 , off Habana, Cuba; $23^{\circ} 10^{\prime}$ $40^{\prime \prime} \mathrm{N}$.; $82^{\circ} 20^{\prime} 30^{\prime \prime}$ W.; 201 fms.; coral.

Albatross Station D. 2319, north of Cuba; $23^{\circ} 10^{\prime}$ $37^{\prime \prime} \mathrm{N}$.; $82^{\circ} 20^{\prime} 06^{\prime \prime} \mathrm{W}$.; 143 fms.; gray coral.

Cotypes.-Cat. Nos. 7543, 7544, U.S.N.M.

\title{
Genus CALLOPORA Gray, 1848
}

\section{CALLOPORA TENUIROSTRIS Hincks, 1880}

\author{
Plate 3, Figure 4
}

1918. Membranipora tenuirostris Watens, Bryozoa of the Cape Verde Islands. Linnean Society's Journal, Zoology, vol. 34, p. 9. (Bibliography and geographic distribution.)

1920. Callopora tenuirostris CANU and BASSler, North American Early Tertiary Bryozoa. Bull. 106, U. S. National Museum, p. 114, pl. 29, fig. 10, 11. (Bibliography.)

Measurements.-Opesia $\left\{\begin{array}{l}h_{0}=0.40 \mathrm{~mm} \text {. } \\ l_{0}=0.24 \mathrm{~mm} \text {. }\end{array}\right.$

$$
\text { Zooecia }\left\{\begin{array}{l}
L z=0.40-0.54 \mathrm{~mm} . \\
l z=0.36 \mathrm{~mm}
\end{array}\right.
$$

Variations.-The micrometric measurements are very variable; specimens from Oran measure $0.50 \mathrm{~mm}$. by $0.44 \mathrm{~mm}$. Waters's figure of 1898 shows $0.40 \mathrm{~mm}$. by $0.28 \mathrm{~mm}$, and fossils from the Jacksonian measure $0.40-0.45 \mathrm{~mm}$. by $0.20-0.25 \mathrm{~mm}$. 
The mural rims are generally separated. They are thick, but when they are covered over by the ectocyst they appear thin. The interzooecial avicularium is large.

Affinities.-This species must not be confused with Membranipora plana Hincks, 1880 , of which we have discovered beautiful specimens at Oran and in which the micrometric measurements are much larger; nor with Callopora parvirostris Canu and Bassler, 1923, of the American Miocene, in which the avicularium is very small. Waters illustrated the mandible in 1885 and the operculum in 1898. We add the ancestrula. Our specimens encrust corals, shells, and Cellepores.

Biology.-Our specimens were living and in reproduction January 30,1885 . This is a species of waters of little depth from 10 to 89 meters, but because of its great vitality it is probable that it can adapt itself to less favorable bathymetric conditions.

Occurrence.-Albatross Station D. 2365, east of Yucatan; $22^{\circ} 18^{\prime}$ $00^{\prime \prime} \mathrm{N}$.; $87^{\circ} 04^{\prime} 00^{\prime \prime} \mathrm{W}$.; $24 \mathrm{fms}$; ; white rock coral. Albatross Station D. 2405, Gulf of Mexico; $28^{\circ} 45^{\prime}$ $00^{\prime \prime} \mathrm{N}$.; $85^{\circ} 02^{\prime} 00^{\prime \prime} \mathrm{W}$.; $30 \mathrm{fms}$; gray sand, broken coral.

Albatross Station D. 2639, Straits of Florida; $25^{\circ} 04^{\prime}$ $50^{\prime \prime} \mathrm{N}$.; $80^{\circ \circ} 15^{\prime} 10^{\prime \prime} \mathrm{W}$.; $56 \mathrm{fms}$.; coral sand.

Geologic distribution.-Eocene (Priabonian) of the Vicentin (Waters); Oligocene of Anguilla (Canu and Bassler); Jacksonian of Mississippi (Canu and Bassler); Helvetian of Tourraine (Canu); Pliocene of Italy (Waters).

\section{CALLOPORA CURVIROSTRIS Hincks, 1861}

Plate 3, Figures 9, 10; Plate 32, Figure 8

1903. Membranipora guernei JuLlien, Bryozoaires provenant des campagnes de l'Hirondelle (1886-1888). Resultats des Campagnes scientifiques du Prince de Monaco, fasc. 23, p. 40, pl. 5, fig. 3.

1918. Membranipora curvirostris Waters, Bryozoa of the Cape Verde Islands. Journal Linnean Society, Zoology, vol. 34, p. 9. (Bibliography.)

1923. Callopora guernei $\mathrm{CANU}_{\mathrm{AN}}$ and BASsLER, North American Later Tertiary and Quaternary Bryozoa. Bull. 125, U. S. National Museum, p. 42, pl. 45 , figs. 3,4 .

$$
\begin{array}{r}
\text { Measurements.-Opesia }\left\{\begin{array}{l}
h_{0}=0.45 \mathrm{~mm} . \\
l_{o}=0.35-0.40 \mathrm{~mm} .
\end{array}\right. \\
\text { Zooecia }\left\{\begin{array}{l}
L_{z}=0.50-0.55 \mathrm{~mm} . \\
l_{z}=0.40-0.45 \mathrm{~mm} .
\end{array}\right.
\end{array}
$$

Variations.-Our specimens encrust shells and large dead colonies of Stylopoma spongites. Above each avicularium there is frequently a curious uncovered space very irregular in form. It is difficult to explain the formation and the origin of these spaces. Waters, 1918, thought that they must be considered as aborted zooecia. In their more perfect form they appear to us to be the unoccupied portion of 
an ordinary zooecium but regenerated by a falciform avicularium. On our specimens from the Gulf of Mexico they are generally absent or diffuse.

Although the specimens dredged in the Philippines belong to the variety albida Busk, 1885, those from the Gulf of Mexico are very typical and conform to Hincks's figure of 1880 . They are deprived of tuberosities on the mural rim. However, we figure a curious specimen in which the zooecia are a little smaller and the mural rim is ornamented with tuberosities very irregularly arranged.

Biology.-All of our specimens were dead. We have observed some cases of total regeneration.

Occurrence.-Albatross Station D. 2167. Off Habana, Cuba; $23^{\circ} 10^{\prime}$ $40^{\prime \prime}$ N.; $82^{\circ} 20^{\prime} 30^{\prime \prime}$ W.; 201 fms.; coral.

Albatross Station D. 2319, North of Cuba; $23^{\circ} 10^{\prime}$ $37^{\prime \prime}$ N.; $82^{\circ} 20^{\prime} 06^{\prime \prime} \mathrm{W}$.; 143 fms.; gray coral.

Pliocene: Minnitimmi Creek, Bocas Island, Almirante Bay, Panama.

Pleistocene (Mount Hope); Panama Canal Zone.

Plesiotypes.-Cat. Nos. 7466, 7467, 70833, U.S.N.M.

\section{CALLOPORA PUMICOSA, new species}

Plate 3, Figure 7

Description.-The zoarium encrusts nullipores; it is formed essentially of a thin calcareous pellicle perforated by a very large number of polygonal pores arranged in irregular quincunx and supporting the zooecia. The latter are isolated, much separated from each other; they are convex, pyriform; the gymnocyst is large and smooth. The opesium is elliptical and not surrounded by a mural rim. The ovicell is globular, smooth, hyperstomial, operculated, and without any connection with the opercular valve.

Measurements.-Opesia $\left\{\begin{array}{l}h_{0}=0.23 \mathrm{~mm} \\ l_{0}=0.11 \mathrm{~mm} .\end{array}\right.$

$$
\text { Zooecia }\left\{\begin{array}{l}
L z=0.45 \mathrm{~mm} \\
l z=0.30 \mathrm{~mm}
\end{array}\right.
$$

Observations. - The nature of the zooecial walls and of the frontal is that of Pyripora; but the ovicell is hyperstomial and there are no spines.

This is one of the most curious species dredged by the Albatross; the nature and function of the porous crust are absolutely unknown but nevertheless it is indeed an integral part of the colony, since the zooecia can communicate among themselves only through it. The biology of this species as of many other bryozoa, is absolutely enigmatical.

Occurrence.-Albatross Station D. 2639, Straits of Florida; $25^{\circ} 04^{\prime}$ $50^{\prime \prime} \mathrm{N}$.; $80^{\circ} 15^{\prime} 10^{\prime \prime} \mathrm{W}$.; 56 fms.; coral sand.

Holotype.-Cat. No. 7468, U.S.N.M.

$58513-28-3$ 
Plate 3, Figure 8

Description.-The zoarium encrusts corals, the zooecia are arranged in uniserial series, ramified at right angles; they are oval, provided with a smooth convex gymnocyst, and terminated by a long, very thin, caudal portion. The ovicell is large, globular, smooth, never closed by the operculum.

$$
\begin{aligned}
& \text { Measurements.- } \text { Opesia }\left\{\begin{array}{l}
h_{o}=0.20 \mathrm{~mm} . \\
l_{o}=0.16 \mathrm{~mm} .
\end{array}\right. \\
& \text { Zooecia }\left\{\begin{array}{l}
L z=0.70-0.90 \mathrm{~mm} . \\
l z=0.20-0.22 \mathrm{~mm} .
\end{array}\right.
\end{aligned}
$$

Affinities.-The form and structure are that of a Pyripora but there is present a hyperstomial ovicell. We have discovered in the Philippines another uniserial species, Callopora uniseriata, in which the dimensions are much larger and in which the caudal portion is very small.

We do not see the necessity of creating a new genus for the reception of this uniserial species in which all the functions are identical with those of other Callopora. Certain zooecia are simply deprived of lateral septules, a suppression which is simply the result of their special mode of development. Certain uniserial Cretaceous species considered as Pyripora are perhaps also Callopora but the number of specimens collected is not sufficiently large to positively affirm the nonexistence of an ovicell.

Our specimens were living and ovicelled, January 17, 1885.

Occurrence.-Albatross Station D. 2319 , north of Cuba; $23^{\circ} 10^{\prime}$ $37^{\prime \prime} \mathrm{N}$.; $82^{\circ} 20^{\prime} 06^{\prime \prime} \mathrm{W}$.; 143 fms.; gray coral.

Holotype.-Cat. No. 7465, U.S.N.M.

\section{CALLOPORA TENUISSIMA, new species}

Plate 26, Figures 1, 2

Description.-The zoarium encrusts shells. The zooecia are distinct, much elongated, elliptical, or fusiform. The mural rim is very thin, smooth. The opesium has the form of the zooecium. The ovicell is small, globular, finely granular. The avicularium is falciform, unguiculated with two small lateral denticles; it is placed in the proximal portion of a zooecium with aborted polypide.

Measurements.-Zooecia $\left\{\begin{array}{l}L z=0.55-0.60 \mathrm{~mm} \text {. } \\ l z=0.30-0.35 \mathrm{~mm} .\end{array}\right.$

Aborted zooecia $\left\{\begin{array}{l}L z=0.50-0.55 \mathrm{~mm} . \\ l z=0.20-0.23 \mathrm{~mm} .\end{array}\right.$

Affinities.-The zooecia with aborted polypides are smaller and especially narrower than the ordinary zooecia. They are always primoserial, but all the primoserial zooecia do not bear avicularia. 
In the genus Flabellaris Waters, 1898, there are frequently internal avicularia. They can not form a constant generic character, for $\mathrm{Am}$ phiblestrum perminutum Hincks, 1880, contains analagous avicularia.

This species differs from Callopora curvirostris Hincks, 1880, in the great delicacy of its mural rim and in the larger dimensions of the zooecia with aborted polypide.

Occurrence.-Albatross Station D. 2387, Gulf of Mexico; $29^{\circ} 24^{\prime}$ N.; $88^{\circ} 04^{\prime}$ W.; 32 fms.

Holotype.-Cat. No. 7469, U.S.N.M.

Genus CAULORAMPHUS Norman, 1903

CAULORAMPHUS OPERTUS, new species

Plate 4, Figures 3-8

Description.-The zoarium encrusts shells. The zooecia are distinct, separated by a deep furrow, at the bottom of which are small interjunctural pores; the mural rim is salient, very thick, and supports 10 pairs of wide thin spines covering the frontal and four large erect distal spines. The pedunculate avicularium is long, thin, and horn shaped.

$$
\begin{aligned}
\text { Measurements.-Opesia }\left\{\begin{array}{l}
h_{o}=0.20 \mathrm{~mm} . \\
l_{0}=0.10 \mathrm{~mm} .
\end{array}\right. \\
\text { Zooecia }\left\{\begin{array}{l}
L z=0.40-0.50 \mathrm{~mm} . \\
l z=0.20-0.25 \mathrm{~mm} .
\end{array}\right.
\end{aligned}
$$

Structure.-The arrangement of the spines is quite unusual and does not resemble that of the spines observed in the other species of the genus. They are flat, almost adjacent, and are inserted in the angle between the dietellae; a very delicate central canalicule runs throughout their length. They are not erect but are recumbent and their ensemble forms a kind of roof above the ectocyst. The four distal spines are large, erect, and articulated at their base.

The arrangement of the dietellae is not the arrangement studied by Norman and characterizing the genus. The dietellae are here parietal and completely surround the zooecium.

The interjunctural pores are visible only on specimens boiled in Javelle water. They are analogous to those which we have observed in Hincksina and in Callopora. They are covered by the ectocyst. Our photographs give a good idea of this remarkable little species.

Occurrence.-Albatross Station D. 2405, Gulf of Mexico; $28^{\circ} 45^{\prime}$ $00^{\prime \prime} \mathrm{N}$.; $85^{\circ} 02^{\prime} 00^{\prime \prime} \mathrm{W}$.; $30 \mathrm{fms}$; gray sand, broken coral.

Cotypes.-Cat. No. 7471 , U.S.N.M.

\section{Genus MEMBRANIPORELLA Smitt, 1873}

1920. Membraniporella CANU and Bassler, North American Early Tertiary Bryozoa. Bull. 106, U. S. National Museum, p. 281. (Description and text figure.) 
Structure.-The frontal is formed by more or less coalesced spines; it is not covered by an ectocyst. The real frontal ectocyst is arranged under the ensemble of costules; it bears the true aperture closed by a simple valve.

Smitt, 1864, noted the flustrine nature of the genotype Lepratia nitida Johnston, 1848 (that is to say, the absence of a compensatrix), and figured (pl. 6, fig. 1) the parietal muscular system. Also in 1867 he placed it in Membranipora. Levinsen, 1909, established the great analogy of the genus Membraniporella with Callopora Gray, 1848. Finally, in the paleontologic evolution, the cribrimorphs began with Membranipora and have always accompanied them since the Cenomanian. There is then no longer any serious reason for putting the two groups in distinct families. The union of the spines above the ectocyst is only a manifestation of calcification and solely a particular means of adaptation or of protection. Is this union of the spines such an essential function of the animal as to justify the creation of a special genus? We still do not know. However, as this generic distinction appears to facilitate the determination, we maintain it and recognize the genus Membraniporella, classing it in the Calloporidae. For the same reason we ought to create a cribrimorph genus corresponding to each of the membraniporoid genera provided with areal spines. We have some examples in the Hincksina stage. In the Membranipores the aperture is always bordered by a sclerite formed by the chitinous thickening of the ectocyst; the opercular valve closes exactly with the peripheral sclerite. In drawings of the opercular valve they are always separated in order to show their presence. The apertural sclerite no longer exits in the cribrimorphs, for it has become useless, the ectocyst adhering to the calcareous armature which surrounds the aperture. Our drawings of the valves of the cribrimorphs can then indicate only the single opercular sclerite.

The visible exterior orifice is not the true aperture since the latter opens on the subadjacent ectocyst, but as it has exactly the same form it is the custom to name it also aperture.

MEMBRANIPORELLA PETASUS, new species

Plate 4, Figures 1, 2

Description.-The zoarium encrusts nullipores and chitinous sponges. The zooecia are distinct, separated by a deep furrow, elliptical, elongated, swollen; the frontal is quite convex; the costules are broad, flat, 9-10 in number, separated by linear lacunae in the middle of their length and by small irregular lacunae in the vicinity of the median axis. The opesium is semielliptical, transverse, with a concave proximal border, larger and with the form of a hat on the ovicelled zooecia; the peristome bears three or four short palmate bifid spines, of which the two lateral ones are wide and in the 
form of a small bifid tongue. The ovicell is large, globular, smooth, hyperstomial.

$$
\text { Measurements.-Aperture }\left\{\begin{array}{l}
h a=0.10 \mathrm{~mm} . \\
l a=0.20 \mathrm{~mm} .
\end{array}\right.
$$

Structure.-We have been able to observe only three small dead specimens, and our observations are necessarily restricted. In its arrangement the ovicell is perhaps not closed by the operculum, but we are not positively certain. It is formed of two calcareous pellicles; the superior pellicle is incomplete in front, leaving thus a small frontal cicatrix; it is completed on the two sides by the two bifid tongues, which are, moreover, intimately united. Its orifice is placed lower than the frontal mucro.

The arrangement of the costules is not at all the ordinary disposition observed in other species of Membraniporella; their extremities are united, leaving between them small, irregularly arranged lacunae. This arrangement is due to the primitive form of the areal spines, which were probably flattened at their extremity like the oral spines. The aspect of the frontal is modified by the form of the spines and by their ramifications. This form of spine in other Membranipores is never a generic character. There is then no serious reason for giving it here a more important significance. Norman, 1909, has noted at Maderia a variety intermedia of Membraniporella nitida Johnston, 1848 , in which the frontal shows modifications quite similar.

Affinities.-This species differs from Membraniporella nitida intermedia Norman, 1909, in the presence of two oral bifid tongues and in the absence of avicularia. It differs from Cribrilina alcicornis Jullien, 1882, in which the orifice is also ornamented by four superb palmate spines, in less numerous and wider costules, and in the presence of large linear lacunae.

Occurrence.-Albaiross Station D. 2167, off Habana, Cuba; $23^{\circ} 10^{\prime}$ $40^{\prime \prime} \mathrm{N}$.; $82^{\circ} 20^{\prime} 30^{\prime \prime} \mathrm{W}$.; $201 \mathrm{fms}$; coral.

Albatross Station D. 2319 , north of Cuba; $23^{\circ} 10^{\prime} 37^{\prime \prime}$

N.; $82^{\circ} 20^{\prime} 06^{\prime \prime}$ W.; 143 fms.; gray coral.

Cotypes.-Cat. Nos. 7550, 7551, U.S.N.M.

\section{Genus CRIBRILINA Gray, 1848}

The genus Cribrilina differs from Membraniporella in the closer spacing of the costules and in their smaller dimensions, their structure in spite of exterior appearances being essentially the same. This difference, including even the perforation of the ovicells in certain species of Cribrilina, is quite feeble. Certainly if this generic distinction is maintained, we will find species with intermediate frontals very difficult to classify. At present we have not changed the 
nomenclature because of the small number of recent species known. Moreover and in consequence of this observation, an exact determination of a Cribrilina can be made only after a special preparation of its costular system. The number of specimens of the same species is almost always quite small and it is then often hard to destroy them in order to make the technical preparations; but it is necessary to decide in favor of science, which is becoming more and more exact.

\section{CRIBRILINA LINEATA, new species}

Plate 3, Figures 5, 6

Description.-The zoarium encrusts nullipores; it is formed of isolated zooecia, arranged in linear series. The zooecia are large, elliptical, elongated; the frontal is very convex surrounded by a kind of smooth gymnocyst to which the costules are attached; the costules are narrow, adjacent, and separated by very small and linear lacunae; they bear at their extremity a salient lumen pore; they are united on the median axis by a salient thread; they are 16 in number. The aperture is semielliptical, transverse, with concave proximal border; the peristome bears two or three short, broad spines and two lateral tongues which develop and unite together sometimes to form an arch above the aperture. The ovicell is hyperstomial, closed by the operculum; it bears a large longitudinal keel and two lateral circular scars.

Measurements.-Aperture $\left\{\begin{array}{l}h a=0.15 \mathrm{~mm} \\ l a=0.25 \mathrm{~mm}\end{array}\right.$.

$$
\text { Zooecia }\left\{\begin{array}{l}
L z=1.00 \mathrm{~mm} . \\
l_{z}=0.60 \mathrm{~mm} .
\end{array}\right.
$$

Structure.-The opercular valve is very thin, the costules are thin and translucent; they are juxtaposed and separated sometimes by very narrow and linear lacunae; they bear an apparent lumen line and three or four small lumen pores; finally they are joined at their base and form the false gymnocyst which surrounds each zooecium. This structure is quite identical with that which Norman, 1903, figured for Cribrilina annulata. He did not illustrate the lumen line because, as he wrote, the opaqueness of the costules prevented the view of it, but in the text he affirms its presence as well as that of the lumen pores. It should be noted also that the variety spitzbergensis of the same species bears as here two lateral tongues to the aperture.

Biology.-Our specimens were in reproduction April 30, 1884. Each colony contains only a very small number of zooecia. The protective influence of the apertural arch is rather difficult to understand; we have observed it only on the ovicelled zooecia; it must retard very much the extrusion of the tentacles. 
Affinities.-This species is deprived of avicularia, but in the Costules their presence is not yet considered as of generic importance. For Cretaceous (Campanian) species very similar in aspect and ornament with an apertural arch Lang, 1922, created the genus Phrynopora.

Occurrence.-Albatross Station D. $2152,2 \frac{1}{2}$ miles northwest of Habana Light, 387 fms.; coral.

Holotype.-Cat. No. 7828, U.S.N.M.

\section{Genus ACANTHOCELlA Canu and Bassler, 1917}

The costules bear a row of very prominent lumen pores and are separated by lacunae of greater or less size. The aperture is semielliptical; the ovicell is hyperstomial and closed by the opercular valve which is much chitinized.

Genotype.-Cribrilina tubulifera Hincks, 1881.

Range.-Eocene (Jacksonian)-Recent.

Structure.-We established this genus in 1917 from a study of fossil specimens from the Jacksonian of the Carolinas. We badly interpreted the function of the opercular valve and we now modify the diagnosis in order to make it conform to the new observations made on recent specimens.

This genus has the same general structure as Membraniporella and Cribritina. The only difference is in the ornamentation of the costules, which appears to us now of very small value, for it does not correspond to an important modification of an essential function of the zooecium. The ornamentation of the frontal depends exclusively on the form of the primitive spines, of simple specific value in Membraniporae as in the Flustridae.

According to our principles of classification, these three genera form really only a single genus for which it is necessary to preserve the name of Cribritina.

The known species of this subgenus are as follows:

Acanthocella tubulifera Hincks, 1881, Recent (Australia).

Acanthocella suggerens Waters, 1881, Miocene (Australia).

Acanthocella erinacea Canu and Bassler, 1922, Jacksonian (Carolina). Acanthocella clypeaia, new species, Recent (Florida).

\section{ACANTHOCELLA CLYPEATA, new species}

Plate 4, Figures 9, 10; text Figure 5

Description.-The zoarium encrusts shells. The zooecia are distinct, elliptical, little elongated; the frontal is convex with the form of a shield; the costules, eight or nine in number are arranged transversely, separated by large lacunae, rectangular, decreasing in size toward the median zooecial axis; the trabeculae of junction are arranged concentrically around the frontal center; each costule bears three lumen pores of which the most exterior one is very salient and 
in the form of a hollow spine. The aperture is semielliptical, transverse; the peristome, thin and salient, bears two or three short, cylindrical hollow spines; the opercular valve is much chitinized. The ovicell is small, hyperstomial closed by the operculum.

$$
\begin{array}{r}
\text { Measurements.-Apertura }\left\{\begin{array}{l}
h a=0.08 \mathrm{~mm} . \\
l a=0.15 \mathrm{~mm} .
\end{array}\right. \\
\text { Zooecia }\left\{\begin{array}{l}
L_{z}=0.50-0.55 \mathrm{~mm} . \\
l z=0.35 \mathrm{~mm} .
\end{array}\right.
\end{array}
$$

Structure.-The figured specimen, living when dredged, permits us to recognize the real structure of this elegant species. The chitinous ectocyst entirely covers the interior of the zooecium; its distal portion is calcified around the aperture and intimately united to the mural rim and to the first costules; the exterior orifice is therefore absolutely similar to the aperture. The opercular valve is much chitinized but it is not detachable. The costules are separated by very large lacunae; their lumen line is very apparent, but the lumen

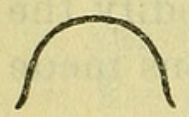

A

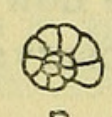

B

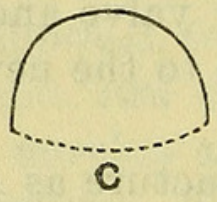

Fig. 5.-ACANTHOCELlA CLYPEATA, NEW SPEcies. A. Opercular valve, $\times 85$. B. A SMALL FORAMINIFER, $\times 85$, FOUND WITHIN a zoofcium. C. Cribrilina lineata, NeW SPECIES, OPERCULUM, $\times 85$

be general in all the Costules.

Affinities.-This new species differs from Acanthocella erinacea Canu and Bassler, 1922, in the presence of four pairs of transverse costules (and not six), in its much smaller dimensions, and in the very salient lateral lumen pores. It differs from Cribrilina tubulifera Hincks, 1881 , in the much wider zooecia, in less numerous costules, and much larger lacunae.

Biology.-The species was in reproduction May 1, 1884. It is very rare.

Occurrence.-Albatross Station D. 2169, off Habana, Cuba; $23^{\circ}$ $10^{\prime} 28^{\prime \prime}$ N.; $82^{\circ} 20^{\prime} 27^{\prime \prime} \mathrm{W}$.; 78 fms.; coral.

Albatross Station D. 2373, Gulf of Mexico; $29^{\circ} 14^{\prime}$ $00^{\prime \prime} \mathrm{N}$.; $85^{\circ} 29^{\prime} 15^{\prime \prime} \mathrm{W}$.; $25 \mathrm{fms}$.; coral.

Holotype.-Cat. No. 7447, U.S.N.M.

\section{Family BUGULIDAE Gray, 1848}

\section{Genus BUGULA Oken, 1815}

BUGULA (STIRPARIA) CARAIBICA Levinsen, 1909

1909. Bugula caraibica Levinsen, Morphological Studies upon the Chilostomatous Bryozoa, p. 104, pl. 11, fig 2. 
1914. Bugularia caraibica Ossunn, Bryozoa from the Tortugas Islands, Florida. Publication Carnegie Institution, Washington, No. 182, p. 188.

Our specimens are rare. They differ from Bugula microecia Osburn, 1914 , in the absence of small oral avicularia and of distal spines on the dorsal. "Growing in loose tufts of a fine purple color" (Osburn).

Occurrence.-Alabatross Station D, 2413, Gulf of Mexico;26 $00^{\prime} 00^{\prime \prime}$ N.; $82^{\circ} 57^{\prime} 30^{\prime \prime}$ W.; 24 fms.; fine sand, black specks, broken shells.

Tortugas (Osburn); St. Croix, Danish West Indies (Levinsen).

BUGULA AVICULARIA Linnaeus, 1758

Plate 4, Figures 13, 14

1889. Bugula avicularia Jeluy, A synomymic Catalogue of Marine Bryozoa, p. 22. (Bibliography.)

1912. Synnotum avicularia OsBurn, Bryozoa of the Woods Hole Region. Bulletin Bureau of Fisheries, vol. 30 (1910), p. 226, pl. 21, fig. 27.

This is a new species for the region of the Gulf of Mexico. It is known, however, from the Atlantic side of Greenland, from Canada, and the United States. The literature upon it is very large. The geographic distribution is still not yet complete. Our specimens were living and ovicelled.

Occurrence.-Albatross Station D. 2392, Gulf of Mexico; $28^{\circ} 47^{\prime}$ $30^{\prime \prime}$ N.; $87^{\circ} 27^{\prime} 00^{\prime \prime}$ W.; 724 fms.; brown-gray mud.

Plesiotypes.-Cat. No. 7457, U.S.N.M.

\section{Genus DENDROBEANIA Levinsen, 1909}

DENDROBEANIA LAMELLOSA, new species

Plate 5, Figures 9-14

Description.-The zoarium is free, unilamellar, of large, broad ramified fronds. The radical fibers are attached on the two sides of the colony; the latter is chitinous. The zooecia are distinct, much elongated, somewhat fusiform; the proximal gymnocyst is very small and often absent; the mural rim is very thin and bears two distal spines and four to six lateral spines. The pedunculate avicularium is large, elongated, acuminated, with the shape of a kidney bean; the mandible is small, in the form of a small tongue. The ovicell is large, globular, smooth.

$$
\text { Measurements.-Zooecia }\left\{\begin{array}{l}
L_{z}=0.75 \mathrm{~mm} . \\
l z=0.35 \mathrm{~mm} .
\end{array}\right.
$$

Affinities.-The form and size of the avicularium being of specific importance in the different genera of this family, we give a photograph of that of the present species. Another photograph shows the structure and the mode of articulation of the spines. 
This species differs from Dendrobeania flabellata Gray, 1847, in the presence of numerous zooecial series on the branches and in the presence of four to six lateral spines in addition to the pair of distal spines.

It differs from $D$. murrayana Johnston, 1847 , in its much wider fronds ( 3 to $4 \mathrm{~mm}$.), in its larger spines, in the interopesial position of the avicularium, in the different form of the avicularium, in the absence of a dorsal sinuosity on the avicularium, and in the mandible placed higher and never extending beyond the peduncule of the avicularium.

Occurrence.-Albatross Station D. 2354, east of Yucatan; $20^{\circ} 59^{\prime}$ $30^{\prime \prime} \mathrm{N}$.; $86^{\circ} 23^{\prime} 45^{\prime \prime} \mathrm{W}$.; 130 fms.; coral.

Cotypes.-Cat. No. 7487, U.S.N.M.

\section{Genus HALOPHILA Busk, 1852}

HALOPHLLA JOHNSTONIAE Gray, 1843

Plate 4, Figure 12

1872. Halophila johnstoniae Smitr, Floridan Bryozoa. Kongl. Svenska Vetenskaps-Akademiens Handlingar, vol. 10, p. 17, pl. 5, fig. 47.

1889. Bugula johnstoniae JELLY, A synonymic catalogue of marine Bryozoa, p. 25. (Bibliography.)

1890. Halophila johnstoniae Kirk Patrick, Hydroida and Polyzoa. Collection made in Torres Strait, Scientific Proceedings Royal Dublin Society, new ser., vol. 6, p. 611.

1926. Halophila johnstoniae HARmer, Polyzoa "Siboga" Expedition, p. 449 , pl. 30 , fig. 14, pl. 31 , figs. 19-21. (Ovicell.)

Our specimens are rare but they were ovicelled.

Desiccation deforms many of the cells; however, our photograph shows that the essential characters are still quite visible, permitting identification. Preparations in Canada balsam show the zooecial form better.

Harmer, 1926, believes that two species have been confused under this name. He reduces considerably Miss Jelley's bibliography and thinks that Ortman's species of 1890 is (?) his Bugula longicauda.

Our specimens correspond rigorously to the figure of Smitt, 1872. As we do not have the necessary elements for comparison, we are not able to modify the synonymy.

The genus Halophila may be provisionally preserved, as the ovicell now known is somewhat divergent from typical Bugula. It is deprived of avicularia.

Occurrence.-Albatross Station D. 2405, Gulf of Mexico; $28^{\circ} 35^{\prime}$ $00^{\prime \prime} \mathrm{N}$.; $85^{\circ} 02^{\prime} 00^{\prime \prime} \mathrm{W}$.; $30 \mathrm{fms}$.; gray sand, broken coral.

Geographic distribution.-Pacific: New Zealand (Gray); Bass Strait (Busk) and Torres Strait, Australia, 5-11 fathoms (Kirkpatrick); N. Celebes, 80 meters (Harmer).

Plesiotypes.-Cat. No. 7510, U.S.N.M. 


\section{Family SCRUPOCELLARIIDAE Levinsen, 1909}

\section{Genus SCRUPOCELLARIA Van Beneden, 1845}

\section{SCRUPOCELLARIA RETIFORMIS Pourtales, 1867}

1872. Caberea retiformis Smitt, Floridan Bryozoa. Kong. Svenska Vetenskaps-Akademiens Handlingar, vol. 10, no. 11, p. 16, pl. 5, figs. 43-46.

1913. Canda retiformis Waters, Bryozoa from Zanzibar. Proceedings of the Zoological Society of London, p. 479, p. 69, figs. 1, 2, 6 . (Bibliography and geographic distribution.)

1914. Canda retiformis OsBunN, Bryozoa from the Tortugas Islands, Florida. Publication Carnegie Institution, Washington, no. 182, p. 192 (cited only).

This species has not been found in America since 1872. We have observed some beautiful specimens. The differences from Canda caraibica Levinsen, 1909, have been given by Osburn, 1914. In accordance with Harmer's studies, this species should be classified in Scrupocellaria.

Occurrence.-Albatross Station D. 2405, Gulf of Mexico; $28^{\circ} 45^{\prime}$ $00^{\prime \prime} \mathrm{N}$.; $85^{\circ} 02^{\prime} 00^{\prime \prime} \mathrm{W} . ; 30 \mathrm{fms}$.; gray sand, broken coral.

Albatross Station D. 2639, Straits of Florida; $25^{\circ} 04^{\prime}$ $50^{\prime \prime} \mathrm{N} . ; 80^{\circ} 15^{\prime} 10^{\prime \prime} \mathrm{W} . ; 56 \mathrm{fms}$.; coral sand.

Florida, 68 and 270 meters (Smitt).

Pliocene: Minnitimmi Creek, Bocas Island, Almirante Bay, Panama.

\section{Family HIANTOPORIDAE MacGillivray, 1895}

\section{Genus TREMOGASTERINA Canu, 1911}

The ovicell is hyperstomial and closed by the operculum. The aperture bears two small cardelles; the operculum, often chitinized, is attached to the ectocyst; the peristome bears three to five hollow spines. The frontal is placed above the ectocyst; it is formed of an olocyst surmounted by a rugose or granulated pleurocyst more or less developed; a central area is perforated by reniform pores. The zooecia are separated by interjunctural pores. Large adventitious avicularia appear between the apertures.

Genotype.-Tremogasterina problematica Canu, 1911. Recent genotypo, Tremogasterina (Lepralia) celleporoides Busk, 1884.

Range.-Cretaceous (Rocanean)-Recent.

The known species are as follows:

Tremogasterina (Lepralia) celleporoides Busk, 1884, Australia.

Tremogasterina (Escharipora) mucronata Smitt, 1872, Florida.

Tremogasterina granulata, new species, Florida.

Tremogasterina ventricosa, new species, Atlantic off Carolina.

Tremogasterina lanceolata, new species, Gulf of Mexico. 
Tremogasterina malleolus, new species, Gulf of Mexico.

Tremogasterina problematica Canu, 1911, Rocanean of Argentina.

Tremogasierina (Poricella) maconnica Canu, 1904, Eocene of Tunis.

Tremogasterina horrida Canu and Bassler, 1923, Miocene of Florida.

Tremogasterina truncatorostris Canu and Bassler, 1923, Miocene of San Domingo.

Tremogasterina (Galeopsis) convexus Canu and Bassler, 1920, Eocene (Midwayan).

Tremogasterina (Lepralia) areolata Reuss, 1874, Tortonian of Austria.

Tremogasterina (Cribrilina) cuspidata Canu and Bassler, 1923, Miocene of Cuba.

Structure.-We have been able to examine a number of recent specimens provided with their chitinous appendages but unfortunately dried. Never have we been able to see the superior ectocyst as in all the other escharian bryozoa (Ascophora). On the contrary, through the frontal pores we have always been able to distinguish the subjacent ectocyst. Moreover, the proximal limit of the opercula being always indecisive, reveals its true nature as an opercular valve attached to the ectocyst. Nevertheless, the anatomical study, after decalcification, of specimens preserved in alcohol is very desirable.

The calcification of the frontal is very difficult to understand. This frontal is formed essentially by an olocyst perforated in the middle by more or less scattered reniform pores, arranged in triangle or like a rose. The superior pleurocyst begins on the sides and invades almost all the frontal, leaving only in the middle an area in which are the reniform pores. We have not been able to observe young zooecia in formation on the zoarial margins nor have we observed directly the development of the pleurocyst. Smitt, 1872, in studying Tremogasterina mucronata seems to have been more fortunate, but he is too brief. He remarks:

As the calcification goes on, at first it fills up the furrows between the zooecia, marking their limits through irregular rows of secondary pores. At last the whole front side of the zooecia is covered by this layer, with the exception of a great hole in their middle into which the above-named lunate pores open themselves.

The pleurocyst is clearly visible around the peristome and on all the ovicells. Removed from all endocystal elements, at least apparently so, its formation is absolutely mysterious. Lang, 1922, has shown an analogous development of secondary tissue in the cribrimorph Tricephalopora group. The chamber thus formed between the ectocyst and the calcified frontal appears to us to be a hypostege in connection with the hydrostatic function; it is a kind of external compensatrix. The entrance of water by the pores permits the extrusion of the tentacles while its exit allows their invagination. While in the other Anasca (Flustrines) the hyposteges communicate 
easily among each other, here they are absolutely individual. This is a specialization which is complete in the Ascophora.

Affinities.-This genus has the structure of the Hiantoporidae in the presence of interjunctural pores and of the large avicularia but we have not seen traces of costules nor of areal spines. In the form of the frontal pores as well as the size of the distal spines, it belongs perhaps to the Arachnopusidae, but we do not know yet if these two families are really distinct. Finally the presence of cardelles, which denotes the presence of a compensatrix in the Ascophora, indicates an ultimate and unexpected perfection. The place of the genus in the family Hiantoporidae is therefore very doubtful. Smitt, 1872, who was able to understand so well the relationships of the bryozoa, had the same doubts. He says:

The present species, without doubt, comes nearest to the true Escharae. Their best systematic place, at least provisionally, will be in the beginning of the Escharine series.

In support of this hypothesis we are able to cite the nature of the opercula, which are very close to those of the Petraliidae.

It is then very difficult to introduce the genus in a known family. We consider it provisionally as an ancestral form which engendered Arachnopusia and Hiantopora, and since we are ignorant of the larva, we prefer to class it doubtfully in the Hiantoporidae in order not to change the present nomenclature.

We have added a second genotype to the genus so as to have a recent species represented. Lepralia celleporoides Busk, 1884, appears to have the greatest geographic distribution. We would have chosen Escharipora mucronata Smitt, 1872, which is the older, if we had had the good fortune to rediscover it.

Distribution.-The different species of the genus have been observed at all depths from 12 to 448 meters. This bathymetric disposition has as a corollary a great geographic distribution. In fact the genus has been observed in the Atlantic, in the Pacific, and in the China Sea. In the Northern Hemisphere it does not go beyond the thirtyfirst parallel, and it is therefore a tropical genus. Its paleontologic distribution was consequently larger, and we have seen fossil representations in the Miocene (Tortonian) from Europe and even in the Eocene of Tunis. The oldest species is Cretaceous (Rocanean of Argentina). The genus appears then to have migrated from the Southern Hemisphere toward the Northern Hemisphere. Canu, 1923, has shown that the genus Mucronella, in which the first representatives have been found in the Cretaceous of Madagascar, has undergone the same phenomenon.

\section{TREMOGASTERINA GRANULATA, new species}

Plate 13, Figures 3, 4; Plate 33, Figure 2; text Figures $6 b-f$

Description.-The zoarium is unilamellar, often cylindrical. The zooecia are distinct, separated by a line of small interjunctural pores, 
elongated, claviform; the frontal is much calcified, granulated, convex, perforated at the middle by a small pore (pseudoascopore). The aperture is suborbicular, somewhat elongated or a little transverse; the proximal border is concave; there are two salient cardelles at the bottom of the peristomie. The ovicell is hyperstomial, much imbedded in the distal zooecium, large, globular, formed of two calcareous superposed lamellae, the exterior of which is also much granulated; the orifice is large and closed by the operculum. The avicularia are large, triangular, much elongated, with a very thin beak and two lateral denticles.

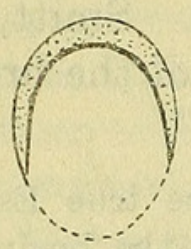

A

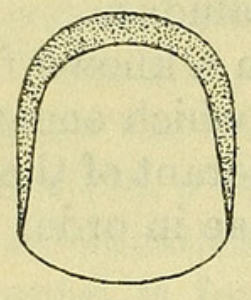

C

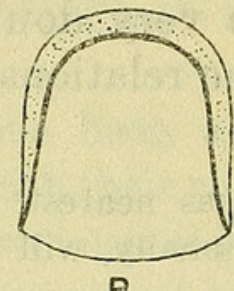

B

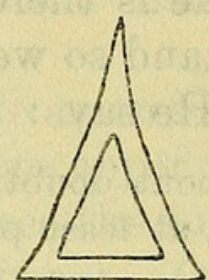

E

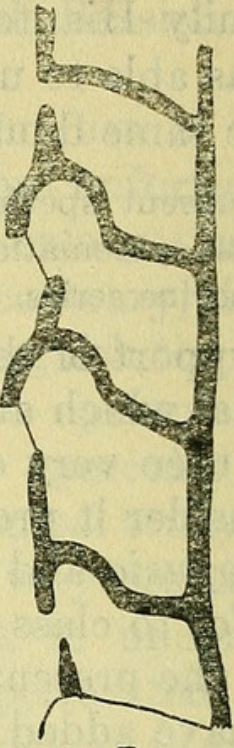

$\mathbf{F}$

Fig. 6.-Genus Tremogasterina Canu, 1911, A. Tremogasterina lanceolata NEW SPECIES. OPERCUlar VALVE, $\times 85$. $B-F$. Tremogasterina granUlata, NEW SPECIES. $B$. ORdiNARY OPERCULUM, $X 85$. $C$. OPERCULUM With thick CHITINOUS BAND. $D$. ANOTHER FORM OF OPERCULUM, $X 85$. $E$. MANDIBLE, $X$ 85. $F$. LONGITUdiNAL SECtion throUgh AN OVICELled SPECIMEN, $X 20$. THE ZOOECIAL WALL IS MUCH CALCIFIED. THE OVICELL IS HYPERSTOMIAL, CLOSED BY THE OPERCULUM

Measurements.-Aperture $\left\{\begin{array}{l}h a=0.20 \mathrm{~mm} \\ l a=0.20 \mathrm{~mm} .\end{array}\right.$

$$
\begin{aligned}
& \text { Zooecia }\left\{\begin{array}{l}
L_{z}=0.75 \mathrm{~mm} . \\
l_{z}=0.35 \mathrm{~mm} .
\end{array}\right. \\
& \text { Avicularia }\left\{\begin{array}{l}
L a v=0.50 \mathrm{~mm} . \\
l a v=0.20 \mathrm{~mm} .
\end{array}\right.
\end{aligned}
$$

Structure.-The opercular valve is much chitinized; it is ornamented with a continuous sclerite distant from the border; it easily separates from the ectocyst but it is attached to it. It is therefore almost analagous to the operculum of Petratia.

Each zooecium is adjacent to two avicularia. The frontal of the latter is very difficult to understand.

On the interior the two cardelles are salient; the frontal is smooth and perforated by the two reniform pores or by three pores arranged in a triangle; the avicularia are not visible, and in spite of their exterior aspect they are clearly adventitious and probably have a zooecial function. 
When the calcification is not too intense, four spines are visible on the very thin peristome; the latter is altogether detached from the pleurocyst which covers the frontal; the latter phenomenon is, moreover, visible on all the species of the genus.

The ectocyst is visible on the inner face of the colonies; it is not on the exterior face, but the specimens dredged alive have a beautiful clear white color.

On the fossil specimens the small cribriform area is little apparent and often closed; the small spines of the peristome are still visible.

Affinities.-This species differs from Tremogasterina mucronata Smitt, 1873 , in the constant absence of the oral mucro and in the absence of three scattered pores on the frontal. It differs from Tremogasterina horrida Canu and Bassler, 1923, from the Miocene of Florida in its larger dimensions, in its smaller cribriform area, in its smaller interjunctural pores, and in its unilamellar zoarium. The three species are very closely related.

Occurrence.-Albatross Station D. 2639 , Straits of Florida; $25^{\circ} 04^{\prime}$ $50^{\prime \prime} \mathrm{N}$.; $80^{\circ} 15^{\prime} 10^{\prime \prime} \mathrm{W}$.; $56 \mathrm{fms}$.; coral sand.

Fowey Light, 15 miles south of Miami, Fla., $40 \mathrm{fms}$. Pliocene: Minnitimmi Creek, Bocas Island, Almirante Bay, Panama.

Cotypes.-Cat. Nos. 7603, 70863, U.S.N.M.

TREMOGASTERINA VENTRICOSA, new species

Plate 13, Figures 1, 2

Description.-The zoarium encrusts nullipores. The zooecia are distinct, separated by a line of interjunctural pores, very large, ventricose; the frontal is convex, rugose, and often bears a large mucro in the vicinity of the aperture; a large orbicular concavity contains a variable number of small reniform pores arranged concentrically. The aperture is suborbicular, very little elongated; the peristome is very thin and accompanied by five beautiful hollow spines arranged above it. The ovicell is globular, very large, rugose. The avicularia are elliptical, very salient; their orifice is triangular with a complete pivot.

$$
\begin{gathered}
\text { Measurements.-Aperture }\left\{\begin{array}{l}
h a=0.25 \mathrm{~mm} . \\
l a=0.22 \mathrm{~mm} .
\end{array}\right. \\
\text { Zooecia }\left\{\begin{array}{l}
L z=1.00 \mathrm{~mm} . \\
l z=0.55 \mathrm{~mm} .
\end{array}\right. \\
\text { Avicularia }\left\{\begin{array}{l}
L a v=0.45 \mathrm{~mm} . \\
l a v=0.30 \mathrm{~mm} .
\end{array}\right.
\end{gathered}
$$

Variations.-This is a very variable species. The mucro is very inconstant, often absent; the number of small pores of the frontal area varies from one zooecium to another; the beak of the avicularium is very pointed or rounded; next to transverse zooecia there are 
very elongated zooecia. Each avicularium is adjacent to three zooecia but rarely a zooecium is adjacent to two avicularia.

Affinities.-Very close to Tremogasterina mucronata Smitt, 1873, in the presence of its frontal mucro, this present species differs in the presence of its concave cribriform area and in the occurrence of five instead of four spines. The figured specimen only has been found.

Occurrence.-Albatross Station D. 2672, Atlantic, east of Georgia; $31^{\circ} 31^{\prime} 00^{\prime \prime} \mathrm{N}$.; $79^{\circ} 05^{\prime} 00^{\prime \prime}$ W.; $277 \mathrm{fms}$.; coarse brown sand.

Holotype.-Cat. No. 7601, U.S.N.M.

\section{TREMOGASTERINA LANCEOLATA, new species}

Plate 13, Figure 9; text Figure $6 a$

Description.-The zoarium encrusts nullipores. The zooecia are distinct, separated by a line of interjunctural pores, very elongated, elliptical; the frontal is convex, very finely granulated; it bears a cribriform concavity perforated by one to five pores. The aperture is pyriform, elongated; two small cardelles separate a large anter from a small, narrow, concave poster; the peristome is thin, salient, ornamented with three large hollow spines. The avicularia are very large, much elongated, lanceolated, with two denticles for pivot.

$$
\begin{gathered}
\text { Measurements.-Aperture }\left\{\begin{array}{l}
h a=0.17 \mathrm{~mm} . \\
l a=0.12 \mathrm{~mm} .
\end{array}\right. \\
\text { Zooecia }\left\{\begin{array}{l}
L z=0.80 \mathrm{~mm} . \\
l_{z}=0.30-0.50 \mathrm{~mm} .
\end{array}\right. \\
\text { Avicularia }\left\{\begin{array}{l}
L a v=0.60 \mathrm{~mm} \\
l a v=0.25 \mathrm{~mm} .
\end{array}\right.
\end{gathered}
$$

Structure.-This is a very fragile species of which minute fragments only have been studied. When the frontal calcification is not too great, five pores are visible in the cribriform area; there is only one of them on the calcified frontals.

The operculum is very thin, absolutely indistinct in its proximal portion, and in consequence directly attached to the ectocyst; it bears an internal and complete sclerite characteristic of the genus.

This species is very well characterized by its large lanceolate avicularia.

Occurrence.-Albatross Station D. 2319 , north of Cuba; $23^{\circ} 10^{\prime}$ $38^{\prime \prime} \mathrm{N}$.; $82^{\circ} 20^{\prime} 06^{\prime \prime} \mathrm{W}$.; 143 fms.; gray coral. Albatross Station D. 2320 , north of Cuba; $23^{\circ} 10^{\prime}$ $39^{\prime \prime} \mathrm{N}$.; $82^{\circ} 18^{\prime} 48^{\prime \prime} \mathrm{W}$.; $130 \mathrm{fms}$.; fine coral.

Holotype.-Cat. No. 7836, U.S.N.M.

\section{TREMOGASTERINA MALLEOLUS, new species}

Plate 13, Figures 5-8; Plate 33, Figure 8

Description.-The zoarium is unilamellar and appears to spread over large surfaces on algae. The zooecia are distinct, separated by 
a line of very small interjunctural pores; the frontal is convex, rugose, ornamented by three reniform pores arranged in a triangle. The aperture is suborbicular; the peristome is very thin and accompanied externally by four long hollow spines. The ovicell is enormous, globular, rugose, embedded in the distal zooecium, closed by the operculum. On the frontal a very salient mucro is developed; it is enlarged at its summit in the form of a hammer. The avicularia are small, with pivot; their beak is truncated.

Measurements.-Aperture $\left\{\begin{array}{l}h a=0.17 \mathrm{~mm} \text {. } \\ l a=0.17 \mathrm{~mm} .\end{array}\right.$

$$
\text { Zooecia }\left\{\begin{array}{l}
L z=0.75 \mathrm{~mm} \\
l z=0.50 \mathrm{~mm}
\end{array}\right.
$$

Variations.-The rich decoration of this species renders it very difficult to study and to figure; it appears to be adapted to quiet waters. The mucro is much attenuated in the convex portions of the zoarium; it is, on the contrary, much developed in the concave portions; it shows, therefore, the general rule observed in all the other bryozoa.

In the intensity of calcification the large frontal pores are obliterated and become little visible.

Sporadically a normal zooecium is replaced by a gigantic avicularium of the same form as the others. Its length is also $0.75 \mathrm{~mm}$.

Each zooecium is adjacent to two avicularia of which one is always larger than the other.

A.finities.-This new species differs very little from Tremogasterina truncatorostris Canu and Bassler, 1923, from the Miocene of Santo Domingo; its mucro is much more developed and its ovicell is smaller. Better fossil specimens may perhaps show the identity of the two species.

Biology.- The species was in reproduction and fixation on February $29,1884$.

On the fossil specimens all the small ornamentation which surrounds the aperture disappears easily or is much attenuated. Nevertheless the species is still recognizable by its micrometric dimensions and its very polymorphic avicularia with truncated beak. The interjunctural pores are often visible on the inferior noncellular face.

Occurrence.-Albatross Station D. 2404, Gulf of Mexico; $28^{\circ} 44^{\prime}$ $00^{\prime \prime} \mathrm{N}$.; $85^{\circ} 16^{\prime} 00^{\prime \prime} \mathrm{W}$.; $60 \mathrm{fms}$.; gray sand.

Albatross Station D. 2136, Caribbean Sea; $17^{\circ} 43^{\prime}$ $40^{\prime \prime}$ N.; $75^{\circ} 38^{\prime} 25^{\prime \prime}$ W.; 52 fms.; coral, broken shells.

Pliocene: Minnitimmi Creek, Bocas Island, Almirante Bay, Panama.

Cotypes.-Cat. Nos. 7602, 70864, U.S.N.M. 
Plate 33, Figure 3

Description.-The zoarium is unilamellar. The zooecia are distinct, separated by a furrow at the bottom of which interjunctural pores are visible, elongated, elliptical. The frontal is convex, finely granular, perforated by four or five round, irregular, separated pores and terminated by a cylindrical mucro more or less salient. The apertura is elliptical, elongated, bordered by a thin peristome. The avicularia are rather large, arranged between the aperture and in the axis of a distal zooecium. They have a fragile pivot and their beak is truncated. The ovicell is globular, somewhat transverse, granular, not closed by the operculum.

$$
\begin{array}{r}
\text { Measurements.-Aperture }\left\{\begin{array}{l}
h a=0.18-0.20 \mathrm{~mm} \\
l a=0.16-0.18 \mathrm{~mm} .
\end{array}\right. \\
\text { Zooecia }\left\{\begin{array}{l}
L z=0.75-0.90 \mathrm{~mm} . \\
l_{z}=0.45-0.50 \mathrm{~mm} .
\end{array}\right.
\end{array}
$$

Affinities.-The avicularia are large when they surmount a distal zooecium; they are small in the contrary case.

This new species differs from the recent Tremogasterina mucronata Smitt, 1873, in its round and nonconcentrically arranged pores and in its truncated avicularia. It differs from the recent Tremogasterina ventricosa in its narrow aperture, in its much smaller zooecia, and in its long and truncated avicularia. It differs from Tremogasterina malleolus in its round, more numerous, and more scattered pores and in its greater micrometric dimensions. The large avicularia measure $0.60 \mathrm{~mm}$. by $0.26 \mathrm{~mm}$.

Occurrence.-Pliocene: Minnitimmi Creek, Bocas Island, Almirante Bay, northwest Panama.

Holotype.-Cat. No. 70865, U.S.N.M.

\section{Genus TREMOPORA Ortmann, 1890}

TREMOPORA RADICIFERA Hincks, 1881

1889. Membranipora radicifera JeLLY, Synonymic Catalogue of Marine Bryozoa, p. 162. (Bibliography.)

We have found only a small specimen of this species but it is typical and well preserved. The zooecia are separated by the interjunctural pores and on the dorsal there are small hydrostatic tuberosities. The occurrence of this species in the recent Gulf of Mexico is quite probable.

Occurrence.-Pliocene: Minnitimmi Creek, Bocas Island, Almirante Bay, Panama.

Distribution.-A widespread species of recent times and in the Miocene of France, Austria, etc. 


\section{Family AETEIDAE Smitt, 1867}

Genus AETEA Lamouroux, 1812

AETEA TRUNCATA Landsborough, 1852

Plate 1, Figure 1; Plate 32, Figure 1

1914. Aetea truncata OsBurn, The Bryozoa of the Tortugas Islands, Florida.

Publication Carnegie Institution, Washington, No. 182, p. 186.

(Bibliography.)

Common in shallow water and down to 5 fathoms, creeping over shells and seaweed (Osburn). A single specimen on shell.

Harmer ("Siboga," 1926) figures the position of the retracted polypide as well as the jointed filiform appendages which appear sporadically in this species. He proves also that the ovicells noted in the genus Aetea are not typical and that they are in reality external ovisacs analogous to those of the Ctenostome genus Nolella.

Occurrence.-Albatross Station D. 2405, Gulf of Mexico; $28^{\circ} 45^{\prime} \mathrm{N}$.; $85^{\circ} 02^{\prime} \mathrm{W}$.; $30 \mathrm{fms}$.

Pliocene: Minnitimmi Creek, Bocas Island, Almirante Bay, Panama.

\section{AETEA SICA Couch, 1844}

\section{Plate 1, Figure 2}

1914. Aetea sica OsBurn, The Bryozoa of the Tortugas Islands, Florida. Publication Carnegie Institution, Washington, No. 182, p. 186. (Bibliography.)

Tortugas at 10 fathoms on shells (Osburn). One specimen on shell.

Occurrence.-Albatross Station D. 2672, Atlantic, east of Georgia; $31^{\circ} 31^{\prime} 00^{\prime \prime} \mathrm{N}$.; $79^{\circ} 5^{\prime} 00^{\prime \prime} \mathrm{W}$.; 277 fms.; coarse brown sand.

Plesiotype.-Cat. No. 7450, U.S.N.M.

\section{Division COILOSTEGA Levinsen, 1909}

\section{Family OPESIULIDAE Jullien, 1888}

\section{Subfamily ONYchocelLIDAE Jullien, 1881}

\section{Genus SMITTIPORA Jullien, 1881}

Smitt (1872) gave two figures ${ }^{7}$ of his Vincularia abyssicola of which one (fig. 60, specimen encrusting a Retepora) shows only the zooecia with ectocyst and the large onychocellaria; in the text he does not describe zooecia without the ectocyst and the form of the opesium. Moreover the zooecia of Velumella americana covered with the ectocyst present absolutely and frequently the same aspect with three regular facettes noted by Jullien as characteristic. This peculiarity

${ }^{7}$ We are not sure that the two figures given by Smitt (in Floridan Bryozoa) of Vincularia abyssicola belong to the same species; this description (of the genus Smittipora) refers solely to fig. 60. (Translation after Jullien, Bulletin de la Societé Zoologique de France, vol. 6, 1881, p. 15.) 
is due to the drying up of the ectocyst and has little connection with the true form of the cryptocyst, for the zooecia without ectocyst have a simple salient mural rim often enlarged into facettes when the cryptocyst is deep. Moreover, the latter have very distinct and often deep opesiular indentations. It is likely that Figure 60 of Smitt corresponds to our Velumella americana but it has been distinctly picked out by Jullien as the type of his genus Smittipora, although unfortunately none of the Cretaceous species which he classes in the genus have either opesiular indentations or onychocellaria. We have made the same observations on our Velumella philippinensis, new species. A dried ectocyst with facettes covers a cryptocyst with opesiular indentations surrounded by a rather regular mural rim and without corresponding facettes.

The genus Smitiipora is therefore not established on sufficient characters since it is the manifest result of an error of interpretation of Smitt's Figure 60.

If Jullien had read closely Smitt's text, he would have understood that this figure represented only the zooecia with ectocyst and did not reveal the form of the opesium. Logically, it is necessary then to exclude the genus Smittipora from the nomenclature.

Since Figure 60 is incomplete and appears to represent another species, Figure 61 remains then the only representative of Vincularia abyssicola. The structure revoaled by Smitt's drawing, in perfect accord with our photographs, is that which we have indicated in our genus Recionychocella. There are no opesiular indentations to the cryptocyst; the opesium is elliptical or subelliptical; the opesiular muscles are placed very high, a little below the hinge of the opercular valve. The onychocellaria are very variable in form and size but they always have the same structure; they are small in Vincularia abyssicola, they are equal to the zooecia, and elliptical in Rectonychocella solida (genotype), and they are narrow and lanceolated in our specimens from the American Jacksonian.

The genus Rectonychocella corresponds to the genus Ogivalia Jullien, 1881 , but with bimembranous onychocellaria.

Our classification of 1922 is correct except that it is necessary to suppress the genus Diplopholos and place its species in Velumella. The zooecial dimorphism on which it was established is only apparent and results simply from the great irregularity of the opesium, a frequent and ordinary phenomenon in all the Onychocellidae. The following table gives a summary of our classification:

Onychocellaria falciform:

Opesiular indentations nonsymmetrical _...

No opesiular indentations _... Ogivalia.

Onychocellaria bimembranous:

Opesiular indentations symmetrical _. _ _ _ _ _ .

No opesiular indentations _... 


\title{
Genus RECTONYCHOCELLA Canu and Bassler, 1917
}

\author{
RECTONYCHOCELLA ABYSSICOLA Smit, 1873
}

Plate 5, Figures 1-3

1873. Vincularia abyssicola Smtтt, Floridan Bryozoa. Kongl. Svenska Vetenskaps-Akademiens Handlingar, vol. 11, p. 6, pl.1, fig. 61 (not 60).

1881. Vincularia abyssicola Hгncks, Contributions, General History of Marine Polyzoa. Annals and Magazine of Natural History, ser. 5, vol. 7 , p. 155 (sep. 42), pl. 10, fig. 4 .

1882. Vincularia abyssicola HrNcks, Annals and Magazine of Natural History, ser. 5 , vol. 9 , p. 85 .

1884. Smittipora abyssicola Hincks, Annals and Magazine of Natural History, ser. 5, vol. 13, p. 358 (sep. 114).

1887. Smitiipora abyssicola Hincrs, Critical notes on the Polyzoa. Annals and Magazine of Natural History, ser. 5, vol. 19, pp. 161, 164.

1891. Onychocelia abyssicola HincKs, Contributions. General History Marine Polyzoa, Annals and Magazine of Natural History, ser. 6, vol. 5, p. 177.

1893. Onychocella abyssicola Hincks, Annals and Magazice of Natural History, ser. 6 , vol. 11 , p. 204.

Measurements.-Opesium $\left\{\begin{array}{l}h_{0}=0.25-0.30 \mathrm{~mm} \\ l_{0}=0.25 \mathrm{~mm}\end{array}\right.$

$$
\text { Zooecia }\left\{\begin{array}{l}
L z=0.75 \mathrm{~mm} \\
l z=0.50 \mathrm{~mm}
\end{array}\right.
$$

Structure.-Our specimen is incrusting, but grows in to free, cylindrical stems formed of six longitudinal series of zooecia, conforming perfectly thus with the specimen studied and figured by Smitt.

The mural rim is somewhat salient, but it is often absent, and the zooecia are then separated by a furrow. The cryptocyst is convex and finely granulated. The opesium is often marginated, either regularly elliptical or presenting only a concave proximal border.

The onychocellarium is much smaller than the zooecia; it is ogival and rather irregular in its dimensions. Smitt's specimen appears to bear somewhat larger onychocellaria-the only appreciable difference.

The micrometric dimensions are quite variable. We have measured a large zooecium of $1.00 \mathrm{~mm}$. by $0.75 \mathrm{~mm}$. and small opesia of 0.20 by $0.15 \mathrm{~mm}$.

A small portion was covered by the ectocyst, and we were thus able to prepare the opercular valve. It is exactly similar to that figured for Velumella by Levinsen, 1909. The attachments of the opesiular muscles are at the same place. The figure of Nordgaard for Rectonychocella solida appears to us then incomplete in its inferior part.

The ancestrula is small and surrounded by five very irregular zooecia.

Affinities.-This species differs from the genotype Rectonychocella solida Nordgaard, 1907, in the presence of much smaller onychocellaria. 
Our photograph is very similar to Smitt's Figure 61. The opesium is elongated, without opesiular indentations, with concave proximal border. The onychocellaria are small, and the mandible is narrow. Harmer, 1926, represents Smittipora abyssicola as having a transverse opesium with two opesiular indentations, with a convex proximal border in which the onychocellarium is large and the mandible is very broad. These characters, absolutely opposed to those which we have observed on Smitt's species, causes us to reject his determination. We give the new name Velumella harmeriana to the species figured by him, which is distinct also in its opesium and its mandible from Velumella levinseni.

The figure of Hincks, 1881 (Singapore or Philippines), conforms also to the drawing of Smitt. Perhaps the slight difference observed in the form of the mandible would authorize the formation of a variety or of a distinct species. We do not understand why Harmer compared this species with his Smittipora cordiformis found by him $i_{n}$ the Malay region. The opesium is not elongated there; its proximal border is concave with feeble opesiular indentations, the onychocellarium is large, and the mandible is very broad. We have not accepted the synonymy of Harmer, and we refer to his species as Velumella cordiformis Harmer, 1926.

Biology.-The considerable reduction of the onychocellarium, compared with the dimensions measured on other specimens of the genus, seem to indicate that Rectonychocella abyssicola lives in a rather rapid marine current.

Occurrence.-Albatross Station D. $2152,21 / 2$ miles northwest of Florida, Habana Light; 387 fms. ; coral. 110 meters, on a Nullipore (Smitt); off Cojima, Cuba, 628 meters (Hincks).

Plesiotype.-Cat. No. 7576, U.S.N.M.

\section{Genus VELUMELLA Canu and Bassler, 1917}

\section{VELUMELLA AMERICANA, new species}

Plate 6, Figures 9, 10; text Figure 7

1873. Vincularia abyssicola Smitт, Floridan Bryozoa, pt. 2. Kongl. Svenska Vetenskaps-Akademiens Handlingar, vol. 11, No. 4, p. 6, pl. 1, fig. 60 (not 61).

1914. Smittipora abyssicola OsBurn, Bryozoa of the Tortugas Islands, Florida. Publication Carnegie Institution, Washington, No. 182, p. 195.

Description.-The zoarium encrusts shells, serpulae, and especially nullipores. The zooecia are distinct, separated by a deep furrow, hexagonal, elongated, often ogival; the mural rim is thin in its distal part, enlarged laterally into facettes along the sides according to the depth of the cryptocyst; the cryptocyst is concave longitudinally, smooth, more or less deep. The opesium is large, somewhat elongated, 
semielliptical, with a convex proximal border and two rather deep lateral opesiular indentations; it is surrounded by a very little salient cushion. The ovicell is small and endozooecial. The onychocellarium is as large as the adjacent zooecia, elliptical or fusiform; its opesium is oval, the point below; the mandible is large, ornamented with two membraneous wings forming an oval ensemble attached to a rachis triangular proximally and setiform at its extremity.

$$
\begin{gathered}
\text { Measurements.-Opesium }\left\{\begin{array}{l}
h o=0.25 \mathrm{~mm} . \\
l o=0.25 \mathrm{~mm} \text {. (with opesiules). }
\end{array}\right. \\
\text { Zooecia }\left\{\begin{array}{l}
L z=0.70-0.80 \mathrm{~mm} . \\
l z=0.40-0.50 \mathrm{~mm} .
\end{array}\right.
\end{gathered}
$$

Variations.-Not a zooecium resembles its neighbor nor does a single onychocellarium resemble another; polymorphism is considerable. The frontal bears three facettes-a median facette formed by the cryptocyst and two lateral facettes formed by the enlargement of the mural rimbut they are not regular. The orientation of the zooecia is indecisive, a phenomenon rather rare in the encrusting bryozoa and caused here by the presence of certain zooecia which engender two or three equal zooecia and by the position of many onychocellaria intercalated sporadically between two adjacent longitudinal series.

Structure.-The ectocyst is thick. The oper-
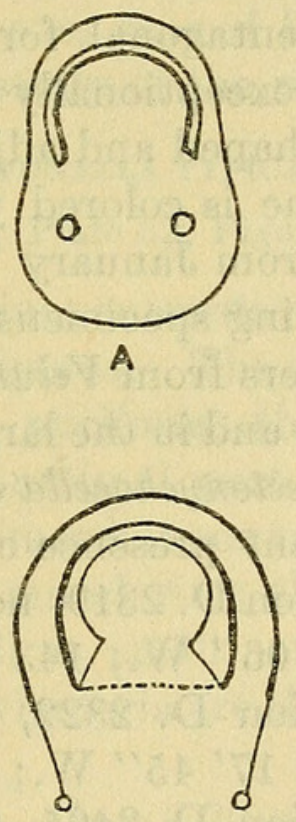

B

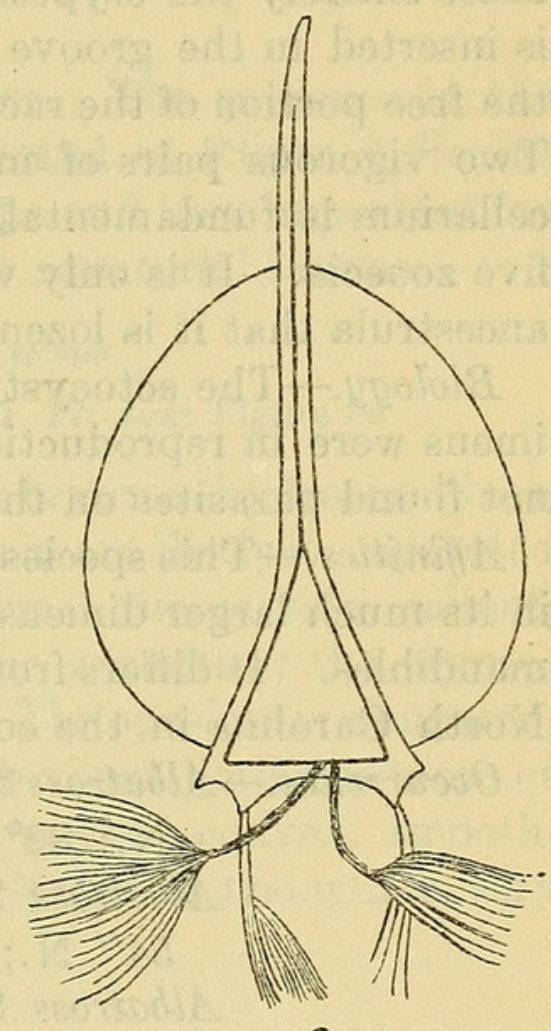

C

Fig. 7.-Velumella americana new species. A. Portion of THE ECTOCYST, $X 85$, COVERING THE OPESIUM, SHOWING THE apertural structure. $B$. Drawing, $\times 85$. C. Mandible OF THE ONYCHOCELLARIUM WITH THE ELEVATOR AND OCCLUSOR MUSCLES, $\times 85$ cular valve is completely surrounded by a kind of peristome formed by the small cushion which surrounds the opesium; it is itself bordered distally and laterally by a little thickened sclerite but of a deeper color. The dimensions are rather constant and slightly transverse, namely, length of opercular valve $0.16 \mathrm{~mm}$; ; width, 0.16 to $0.18 \mathrm{~mm}$. The aperture exactly closed by the valve is bordered by a large sclerite, placed on the internal side of the cushion and attached to the two extremities of the opercular sclerite. On the external side of the 
opesial cushion there is another exterior sclerite prolonged under the valve up to the opesiule. This character is little visible on the photograph, for it is manifested especially by a slight modification in the color of the ectocyst. When the ectocyst is dried, it is supported on the facettes of the frontal and assumes the aspect of Smitt's Figure 60 but with much less regularity; this appearance causes us to suppose that it represents more the present species than that shown in Figure 61. On the same dried ectocyst the trace of opesiular muscles is indicated by two small concavities placed exactly at the level of the opesiular indentations.

The onychocellarium is provided with a large bimembranous mandible. The membrane is very thin and oval. When the mandible is raised it hides a part of the distal zooecium; when it is lowered it hides entirely the cryptocyst of the onychocellarium ${ }^{8}$ and the rachis is inserted in the groove which separates the two proximal zooecia; the free portion of the rachis is very flexible and takes different forms. Two vigorous pairs of muscles move the mandible. Each onychocellarium is fundamentally pentagonal, for it is always adjacent to five zooecia. It is only very exceptionally and in the vicinity of the ancestrula that it is lozenge-shaped and adjacent to four zooecia.

Biology.-The ectocyst alone is colored yellow. Our living specimens were in reproduction from January to May, 1885. We have not found parasites on the living specimens.

Affnities.- This species differs from Velumella pusilla, new species, in its much larger dimensions and in the large oval membranes of the mandibles. It differs from Rectonychocella elongata of the Miocene of North Carolina in the constant presence of opesiular indentations. Occurrence.-Albatross Station D. 2319, north of Cuba; $23^{\circ} 10^{\prime} 37^{\prime \prime}$ N.; $82^{\circ} 20^{\prime} 06^{\prime \prime}$ W.; 143 fms.; gray coral.

Albatross Station D. 2322, north of Cuba; $23^{\circ} 10^{\prime}$ $54^{\prime \prime}$ N.; $82^{\circ} 17^{\prime} 45^{\prime \prime} \mathrm{W}$.; 115 fms.; coral. Albaiross Station D. 2405, Gulf of Mexico; $28^{\circ} 45^{\prime}$ $00^{\prime \prime} \mathrm{N}$.; $85^{\circ} 02^{\prime} 00^{\prime \prime} \mathrm{W}$.; 30 fms.; gray sand, broken coral.

Fowey Light, 15 miles south of Miami, Fla., 64 miles from Florida; 77 meters (Smitt), Tortugas; low water to 24 meters (Osburn).

Cotypes.-Cat. No. 7612, U.S.N.M.

\section{Subfamily MiCROPORIDAE Hincks, 1880}

\section{Genus DACRYONELLA Canu and Bassler, 1917}

The polypidian convexity protrudes very little and is inconstant. The opesiules are large, round, lateral indentations. The ovicell is endozooecial. There are no opesial processes (therefore an opercular

8 This phenomenon is general in all the Opesiulidae. We have found it in the mandibular opercula of Steganoporella and in opercular mandibles of Siphonoporella. 
valve). The opesium is elongated (therefore the parietal muscles are much developed). The avicularia are very small, constant, placed in all the interzooecial angles, and have the form of small tear drops.

Genotype.-Dacryonella octonaria Canu and Bassler, 1917. Recent genotype, Dacryonella typica new species.

Range.-Cretaceous (Santonian)-Recent.

Siructure.-In 1920 we pointed out the morphologic characters of this genus based on a fossil species found in the Eocene (Jacksonian). The study of recent specimens has entirely confirmed our deductions and we have no changes to make. However, it is preferable to accept for a second genotype a recent species from the Gulf of Mexico which will always be easy to procure for further study relative to the anatomy or to the larval system. We have discovered four other recent species in the Philippines.-Dacryonella ogivalina, D. papillata, D. trapezoides, and $D$. subvespertilio.

Up to the present this is a tropical genus. The presence in the European Cretaceous (Santonian) of the island of Rügen indicates the warmth of the Cretaceous seas of Europe and how important for the paleontologist is the study of the recent equatorial faunas.

DACRYONELIAA TYPICA, new species

Plate 5, Figures 4-8; Plate 32, Figures 11, 12; text Figure $8 a$

Description.-The zoarium encrusts other bryozoa, hydrocorallines, corals, serpulae, and nullipores. The zooecia are distinct, separated by an elongated furrow, pyriform; the mural rim is thin, salient, much attenuated in the proximal part of the zooecium; the cryptocyst is smooth, shallow, somewhat convex. The opesium is elongated, pyriform, limited by the mural rim; the proximal border is more or less convex. The ovicell is small, endozooecial, convex, smooth. The small interzooecial avicularia are thin, elongated, triangular, very constant.

Measurements.-Opesium $\left\{\begin{array}{l}h_{0}=0.20 \mathrm{~mm} . \\ l_{0}=0.15 \mathrm{~mm} .\end{array}\right.$

$$
\text { Zooecia }\left\{\begin{array}{l}
L z=0.45 \mathrm{~mm} \\
l_{z}=0.30 \mathrm{~mm}
\end{array}\right.
$$

Variations.-Our measurements are average for the variations are so great on the same colony that it is impossible to give them accurately. The species of this genus are, moreover, quite variable; it is very difficult to differentiate those with nearly similar measurements, and one must have several specimens to make an exact determination. The ancestrular zooecia have a small opesium with a large cryptocyst; the marginal zooecia have a very large opesium and a small cryptocyst.

Structure.-The lateral indentations of the opesium appear to indicate the place of the opesiular muscles, but we have not been able to 
confirm this because our specimens had become dried. The ectocyst, moreover, is very thin. The opercular valve is semielliptical, transverse, and measures about $0.12 \mathrm{~mm}$. by $0.07 \mathrm{~mm}$; on our preparations it appears thicker in its median portion. The small avicularia measure at the maximum $0.10 \mathrm{~mm}$. by $0.05 \mathrm{~mm}$.; we do not understand their utility for zooecia relatively so large.

Affinities.-This recent species differs from Dacryonella octonaria Canu and Bassler, 1917, of the Eocene (Jacksonian) in its oval opesium, its deeper opesiular indentations, and its unilamellar zoarium.

Biology.-The colonies have a light rose color. Our specimens

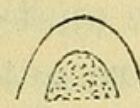

A

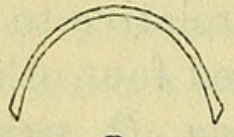

B

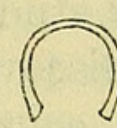

C

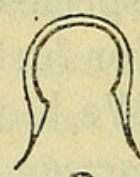

D

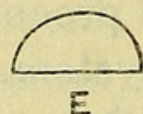

E
Fig. 8.-Opercular valves of Opesiulae. A. Dacryonella typica, NEW SPECIES. VALVE SOMEWHAT THICKENED IN THE MIDDLE. $B$. Floridinella typica, NeW species. $C, D$. Floridina antiQua SMITT, 1873. E. MiCropora CORIACEA EsPER, 1791

were dredged alive and were in reproduction January 17, 1885. This is a species of deep waters and a commensal of the marine currents. We have observed some cases of total regeneration in the vicinity of the ancestrula. Occurrence.-Albatross Station D. 2319, north of Cuba; $23^{\circ} 10^{\prime}$ $37^{\prime \prime} \mathrm{N}$.; $82^{\circ} 20^{\prime} 06^{\prime \prime} \mathrm{W}$.; 143 fms.; gray coral.

Albatross Station D. 2320, north of Cuba; $23^{\circ} 10^{\prime}$ $39^{\prime \prime}$ N.; $82^{\circ} 18^{\prime} 48^{\prime \prime}$ W.; 130 fms.; fine coral.

Albatross Station D. 2160, off Habana, Cuba; $23^{\circ} 10^{\prime}$ $31^{\prime \prime}$ N.; $82^{\circ} 20^{\prime} 37^{\prime \prime}$ W.; 167 fms.; coral.

Pliocene: Minnitimmi Creek, Bocas Island, Almirante Bay, Panama.

Cotypes.-Cat. Nos. 7484, 7485, 70838, U.S.N.M.

\section{Genus FLORIDINELLA Canu and Bassler, 1917}

The ovicell is endozooecial and separated from the zooecia by a fold. The polypidian convexity is not prominent. The opesiular indentations are large and rounded. The opesium is constricted by two symmetrical lateral teeth at the level of the opercular articulation.

Genotype.-Floridinella vicksburgica Canu and Bassler, 1917. Recent genotype, $F$. typica, new species.

We based this genus on fossil specimens from the Oligocene (Vicksburgian), but the study of recent specimens has not caused us to make any changes in our diagnosis. As in similar cases, the recent species should be accepted as a second genotype.

The opercular valve is supported on two small lateral condyles, but it is always adjacent to the mural rim. In Floridina, on the contrary, it is isolated from the mural rim. Moreover, on our specimens 
we have never observed onychocellaria. This absence of adventitious organs appears to indicate a genus which is commensal in the great marine currents.

FLORIDINELLA TYPICA, new species

\section{Plate 6, Figures 6, 7; text Figure $8 b$}

Description.-The zoarium encrusts shells and nullipores. The zooecia are distinct, separated by a furrow, irregularly oval, somewhat elongated; the mural rim is very thin, smooth, salient, complete; the cryptocyst is shallow, flat, granulated. The opesium is large, subtrifoliated; the proximal border is concave or convex with very small opesiular indentations; the two lateral condyles are small and deep. The ovicell is endozooecial, small, little salient. There are frequently small interzooecial tuberosities.

Measurements.-Opercular valve $\left\{\begin{array}{l}h a=0.08 \mathrm{~mm} \\ l a=0.14 \mathrm{~mm} .\end{array}\right.$

$$
\text { Zooecia }\left\{\begin{array}{l}
L z=0.50 \mathrm{~mm} \\
l_{z}=0.40 \mathrm{~mm}
\end{array}\right.
$$

Variations.-This species is very irregular in its micrometric measurements, but its general aspect is rather constant. The two lateral condyles on which the opercular valve is supported are not always very apparent, for they are deeply located and attached to the inferior part of the mural rim. The small interzooecial tuberosities, although sporadic, are very characteristic. The opesiular indentations are not always visible, for the proximal border of the opesium is often concave.

This species is not so beautiful, so vigorous, or so characteristic as the fossil genotype, Floridinella vicksburgica, but as it is the only recent species to be procured in abundance we have chosen it as the recent type of the genus.

Biology.-Our living specimens were ovicelled.

Occurrence.-Albatross Station D. 2639, Straits of Florida; $25^{\circ} 04^{\prime}$ $50^{\prime \prime} \mathrm{N}$.; $80^{\circ} 15^{\prime} 10^{\prime \prime} \mathrm{W}$.; $56 \mathrm{fms}$; coral sand.

Fowey Light, 15 miles south of Miami, Fla.; $40 \mathrm{fms}$. Cotypes.-Cat. No. 7497, U.S.N.M.

\section{FLORIDINELLA PARVULA, new species}

\section{Plate 6, Figure 8}

Description.-The zoarium encrusts nullipores and gastropod mollusks. The zooecia are small, distinct, separated by a deep furrow, oval, short; the mural rim is thin, small salient, much attenuated proximally; the cryptocyst is short, flat, shallow. The opesium is oval, elongated, trifoliate; the two lateral condyles are salient; the proximal border is convex with two irregular opesiular indentations. The 
ovicell is small and endozooecial. Sometimes small tubercles appear sporadically between the zooecia.

$$
\begin{array}{r}
\text { Measurements.-Opesium }\left\{\begin{array}{l}
h_{o}=0.12 \mathrm{~mm} . \\
l_{o}=0.07 \mathrm{~mm} .
\end{array}\right. \\
\text { Zooecia }\left\{\begin{array}{l}
L_{z}=0.25 \mathrm{~mm} . \\
l_{z}=0.20 \mathrm{~mm} .
\end{array}\right.
\end{array}
$$

Biology.-All of our specimens were dead. The number of species of bryozoa which encrust gastropods is rather restricted, and they are generally small. They appear to find in the irregularities of the surface of mollusks conditions unfavorable to their development.

Occurrence.-Albatross Station D. 2639, Straits of Florida; $25^{\circ} 04^{\prime}$ $50^{\prime \prime} \mathrm{N}$.; $80^{\circ} 15^{\prime} 10^{\prime \prime} \mathrm{W}$.; 56 fms.; coral sand.

Holotype.-Cat. No. 7498, U.S.N.M.

\section{Genus FLORIDINA Jullien, 1881}

The retractor muscles of the polypide are attached in the median axis of the zooecium. The opesiular indentations are symmetrical, very large, limited above by the two very salient opesial processes and placed on each side of a much produced, semitubular, polypidian convexity. The zooecium is closed by an operculum attached to the ectocyst; the opercular axis of rotation is located above the two opesial processes. The onychocellaria are straight, without the small distal canal, rounded at their apex; the mandible is bimembranous. Ovicell endozooecial.

The genus Floridina is apparently restricted to the equatorial zone in the Gulf of Mexico for it has not yet been found in any other locality. We have observed it fossil in the Jacksonian of Mississippi, Georgia, and North Carolina. It disappeared in the Vicksburgian of Alabama and Mississippi, probably due to cooling of the temperature.

FLORIDINA ANTIQUA Smitt, 1873

Plate 6, Figure 1; text Figures $8 c, d$

1873. Mollia antiqua Smitr, Floridan Bryozoa, pt. 2. Kongl. Svenska Vetenskaps-Akademiens Handlingar, vol. 11, no. 4, p. 12, pl. 2, fig. 73 (not Busk 1853).

1881. Floridina antiqua Jullien, Nouvelle division des Bryozoaires cheilostomiens. Bulletin de la Société Zoologique de France, vol. 6, p. 14.

Structure.-The microporoid structure of this species did not escape Smitt who allied it with the group Micropora, Thalamoporella, and Steganoporella with a certainty really remarkable at an epoch when the anatomical studies were still much restricted. Jullien in 1881 and 1888 was the first to discover the function of the opesiular muscles and to determine the structure of the frontal. Our generic definition of 1920 is correct, as our new study of the genotype confirms it. 
The ectocyst entirely surrounds the zooecium; a sclerite little thickened surrounds the termen of the mural rim. The aperture, semielliptical and transverse, is bordered with a strong sclerite in which the sclerite of the opercular valve is exactly inserted. We are obliged to separate these two sclerites on our figures in order to show their independence, but on the specimen it is impossible to separate them.

The opercular valve is supported laterally on the two condyles of the opesium. It is always removed from the mural rim, especially laterally. The attachments of the opeciular muscles are indicated in the opercular preparations by two black points rather removed from the hinge joint of the valve.

The opesium, very constant in its general form, is very irregular in its dimensions; the two lateral condyles are large and salient. The mural rim is salient and the cryptocyst is somewhat granulated.

The onychocellarium is oval, often triangular in its distal portion. The two membraneous wings of the mandible are very fragile and we have not yet been able to make a good preparation of them.

In 1920 we determined as Floridina aniiqua a Jacksonian species much larger and much more vigorous. We were deceived by the enlargement of the figure of Smitt, who has never given the magnification of his drawing. It is necessary then to change the name of the fossil species to which we here apply the new name Floridina robusta.

Measurements.-Opesium $\left\{\begin{array}{l}h_{0}=0.14-0.16 \mathrm{~mm} \text {. } \\ l_{0}=0.20 \mathrm{~mm} .\end{array}\right.$

Zooecia $\left\{\begin{array}{l}L z=0.40-0.50 \mathrm{~mm} \\ l_{z}=0.40 \mathrm{~mm} .\end{array}\right.$

Opercular valve $\left\{\begin{array}{l}h_{0}=0.08 \mathrm{~mm} . \\ l_{0}=0.10 \mathrm{~mm} .\end{array}\right.$

Onychocellaria $\left\{\begin{array}{l}h o n=0.30 \mathrm{~mm} . \\ \text { lon }=0.16-0.20 \mathrm{~mm} .\end{array}\right.$

Biology.-Our living specimens were ovicelled April 9, 1885. The ectocyst only is pigmented with a clear brown. This color is not constant and depends on the substratum, for one of our specimens is rose colored on one side and green on the other, according to the color of the nullipore which it encrusts. The greater part of the time the pigmentation appears to be that of the phytoplancton. To the present time this species has not been dredged from great depths.

Occurrence.-Albatross Station D. 2405, Gulf of Mexico; $28^{\circ} 45^{\prime}$ $00^{\prime \prime}$ N.; $85^{\circ} 02^{\prime} 00^{\prime \prime}$ W.; $30 \mathrm{fms}$.; gray sand, broken coral.

Albatross Station D. 2639, Straits of Florida; $25^{\circ} 04^{\prime}$ $50^{\prime \prime}$ N.; $80^{\circ} 15^{\prime} 10^{\prime \prime} \mathrm{W}$.; $56 \mathrm{fms}$.; coral sand.

Fowey Light, 15 miles south of Miami, Fla.; $40 \mathrm{fms}$. Florida, 47-71 meters (Smitt).

Plesiotypes.-Cat. Nos. 7495, 7496, U.S.N.M. 


\section{Genus MICROPORA Gray, 1848}

\section{MICROPORA CORIACEA Esper, 1791}

Text Figure $8 e$

1873. Micropora coriacea Smitt, Floridan Bryozoa. pt. 2. Kongl. Svenska Vetenskaps-Akademiens Handlingar, vol. 11, no. 4, p. 13, pl. 2, fig. 74 .

1920. Micropora coriacea Canu and Bassler, North American Early Tertiary Bryozoa. Bull. 106, U. S. National Museum, p. 235, pl. 4 figs. 20-22. (Bibliography, geographic and geologic distribution.)

Measurements.-A perture $\left\{\begin{array}{l}h a=0.06 \mathrm{~mm} . \\ l a=0.12 \mathrm{~mm} .\end{array}\right.$

$$
\text { Zooecia }\left\{\begin{array}{l}
L z=0.44-0.50 \mathrm{~mm} \\
l_{z}=0.26-0.30 \mathrm{~mm}
\end{array}\right.
$$

Variations.-Our micrometric measurements are a little less than those exhibited on the fossil specimens; they, however, conform to the usual variations of the species.

The aperture is closed by a true light-colored very simple operculum which we have illustrated. Smitt gave its length 0.12-0.16 mm. in conformity with our measurements.

Biology.-Our specimens encrust shells and nullipores. Many of them were living and ovicelled in March and April, 1885.

Occurrence.-Albatross Station D. 2405, Gulf of Mexico; $28^{\circ} 45^{\prime}$ $00^{\prime \prime}$ N.; $85^{\circ} 02^{\prime} 00^{\prime \prime}$ W.; 30 fms.; gray sand, broken coral.

Albatross Station D. 2639, Straits of Florida; $25^{\circ} 04^{\prime}$ $50^{\prime \prime} \mathrm{N} . ; 80^{\circ} 15^{\prime} 10^{\prime \prime} \mathrm{W}$.; 56 fms.; coral sand.

Florida, 58 to 218 meters (Smitt).

\section{Family CALPENSIIDAE Canu and Bassler, 1923}

\section{Genus HEMISEPTELLA Levinsen, 1909}

\section{HEMISEPTELLA DENTICULATA Smitt, 1873}

\section{Plate 9, Figure 9}

1873. Biflustra denticulata Smit, Floridan Bryozoa. Kongl. Svenska Vetenskaps-Akademiens Handlingar, vol. 11, no. 4, p. 18, pl. 4, figs. 89-91.

Measurements (after Smitt).-

Operculum $\left\{\begin{array}{l}h_{0}=? \\ l_{0}=0.10 \mathrm{~mm}\end{array}\right.$

Zooecia $\left\{\begin{array}{l}L_{z}=0.58 \mathrm{~mm} . \\ l_{z}=0.28 \mathrm{~mm} .\end{array}\right.$

Structure.-The figures of Smitt are perfectly exact. We class the species in Hemiseptella because of the presence of opesial spicules, but we have not seen the trace of opesiular muscles on the ectocyst. The 
irregularity of the proximal portion of the opesium indicates that the retractor muscles of the polypide are not attached to the zooecial median axis. The ectocyst is light colored when it is not pink, very thin, and almost transparent.

Biology.-The colony expands often over large surfaces and one of our specimens measured 4 by 2 centimeters. It becomes pigmented easily. Smitt cited the cryptocyst as being of a marine-bluish hue; one of our specimens was rose and green and covered by a flesh-colored ectocyst.

We have observed colonies developed on the two sides of a dead shell. This is a phenomenon that is not rare, but the explanation of it is difficult. It is necessary to admit either an accidental turning of the shell or its vertical position between two stones which serve to support it. This is almost a littoral species.

Occurrence.-Tortugas, Florida, 16 meters (Smitt); Punta Rosa, Florida.

Plesiotype.-Cat. No. 7513, U.S.N.M.

HEMISEPTELLA HEXAGONALIS, new species

Plate 28, Figure 9

Description.-The zoarium is incrusting. The zooecia are distinct, separated by a very thin and shallow furrow, hexagonal, somewhat elongated; the mural rim is thin and finely granulated; the cryptocyst is concave, little developed, much smaller than the opesium, granulated. The opesium is large, elongated, dissymetric in its proximal portion, often subtrifoliate; it is bordered by short and widely spaced spicules. In all the interzooecial angles there is a large smooth and hollow tubercle.

$$
\begin{gathered}
\text { Measurements. - Opesium }\left\{\begin{array}{l}
h_{0}=0.30 \mathrm{~mm} . \\
l_{0}=0.24 \mathrm{~mm} .
\end{array}\right. \\
\text { Zooecium }\left\{\begin{array}{l}
L z=0.45 \mathrm{~mm} . \\
l_{z}=0.35 \mathrm{~mm} .
\end{array}\right.
\end{gathered}
$$

Affinities.-The micrometric dimensions are quite variable; of the primoserial, adjacent zooecia, there is one of them always shorter. The initial zooecium of a series is frequently broader. The cryptocyst is little developed on the marginal zooecia.

This species differs from Hemiseptella (Biflustra) denticulata Smitt, 1873, in its granulated and much smaller cryptocyst. It differs from Membranipora denticulata Busk, 1856, of Mazatlan in the presence of large tubercles and in its hexagonal zooecia. It differs from Hemiseptella tuberosa Canu and Bassler, 1923, from the Pleistocene of South Carolina in its much larger dimensions. The very special form of the opesium does not permit us to compare this species with Nitscheina (Membranipora) of the membranacea group. 
Occurrence.-Albatross Station D. 2619, western Atlantic; $33^{\circ} 38^{\prime}$ N.; $77^{\circ} 36^{\prime}$ W.; 15 fms.; coarse yellow sand and broken shells. Holotype.-Cat. No. 7512, U.S.N.M.

\section{Genus CUPULARIA Lamouroux, 1821}

CUPULARIA DOMA D'Orbigny, 1852

Plate 6, Figures 2-5

1923. Cupularia doma CANU and BAssler, North America Later Tertiary and Quaternary Bryozoa. Bull. 125, U. S. National Museum, p. 77 , pl. 1, fig. 18, pl. 15, figs. 1-5.

The reader is referred to our work of 1923 for the bibliography and remarks upon this species which, although associated in the recent and ancient Gulf of Mexico with the widespread $C$. umbellata Defrance, 1823 , is readily distinguished by its more conical form and its spinous processes not joined together.

Occurrence.-Albatross Station D. 2639, Straits of Florida; $25^{\circ} 04^{\prime}$ $50^{\prime \prime} \mathrm{N}$.; $80^{\circ} 15^{\prime} 10^{\prime \prime} \mathrm{W}$.; 56 fms.; coral sand. Florida, 47 meters (Smitt).

Plesiotypes.-Cat. No. 7830, U.S.N.M.

\section{CUPUlaRIA UMBELLATA Defrance, 1823}

Plate 7, Figures 1-3

1914. Cupularia lowei OsBurn, Bryozoa of the Tortugas Islands, Florida. Publication Carnegie Institution, Washington, no. 182, p. 194.

Our specimens from the Gulf of Mexico are not as fully developed as the European fossil specimens, for in the French Redonnian it is not rare to find zoaria 1 centimeter in diameter. This species is so common that we are convinced many variations are possible. It appeared with the inauguration of the Miocene and it has rapidly propagated in the Atlantic, but on the American side is now much less common and is in course of extinction.

Occurrence.-Various localities in the Gulf of Mexico; Tortugas, 19-35 meters (Osburn); Florida, 47 meters (Smitt). Atlantic; Beaufort, N. C. (Osburn); Cape Fear River, 11 meters (Smitt).

Plesiotypes.-Cat. No. 7831, U.S.N.M.

Family STEGANOPORELLIDAE Hincks, 1884

\section{Genus STEGANOPORELLA Smitt, 1873}

STEGANOPORELLA MAGNILABRIS Busk, 1854

Plate 7, Figures 8-10; Plate 32, Figure 6

1923. Steganoporella magnilabris $\mathrm{CANU}_{\mathrm{ANU}}$ and BASsLER, North American Later Tertiary and Quaternary Bryozoa. Bull. 125, U. S. National Museum, p. 63, pl. 14, figs. 12, 13. (Bibliography.)

1926. Steganoporella magnilabris Harmer, Polyzoa "Siboga" Expedition, pt. 2, p. 277 , pl. 17, figs. 1-3, 7, 9, 12, text fig. 10. (Bibliography and anatomical studies.) 


$$
\begin{gathered}
\text { Measurements. }- \text { Operculum }(A \text { zooecia })\left\{\begin{array}{l}
h_{0}=0.40-0.45 \mathrm{~mm} \\
l_{0}=0.50 \mathrm{~mm} .
\end{array}\right. \\
\text { Operculum }(B \text { zooecia })\left\{\begin{array}{l}
0.60 \mathrm{~mm} . \\
0.75 \mathrm{~mm} .
\end{array}\right. \\
\text { Zooecia } A_{\left\{\begin{array}{l}
h \\
l_{z}=0.75 \mathrm{~mm} .
\end{array}\right.} \\
\text { Zooecia } B\left\{\begin{array}{l}
1.25-1.50 \mathrm{~mm} . \\
0.75 \mathrm{~mm} .
\end{array}\right.
\end{gathered}
$$

Structure.-Since the fine work of Harmer, 1890, and that of Waters, 1913, the internal structure of this remarkable animal is now very well known. We agree entirely with the masterly work of Harmer, 1926.

The ectocyst, naturally light colored, is thick and entirely covers all the zooecia; it is smooth but generally dirty. The hinge of the operculum is placed at the level of the orifice of the polypidian tube. The trace of opesiular muscles is quite visible and revealed by two concavities symmetrically disposed on the dried specimens.

The structure of the $A$ opercula is quite special and well known; but that of the $B$ opercula has been up to the present poorly interpreted because absolutely unexpected. In short, it is the structure of an avicularium with its rachis with two small pillars arranged in a triangle. It is therefore a mandibular operculum. It fills the triple function of assuring the closing of the zooecium, the entrance of the hypostege and oxygenation compatible with the extreme vigor of the zooecia. The hooks of the peripheral sclerite grip the mural rim and assure the closing. The size of this mandibular operculum is exactly that of the cryptocyst which it covers entirely and exactly when the cell is open.

The occlusur muscles of the $A$ opercula are attached to the longitudinal sclerites and at the level of the superior extremity of the tentacular sheath; they form three vigorous bundles; we reproduce an unretouched photograph. When the mandibular $B$ operculum is open all the interior of the cell thus visible is lined by a membranous cryptocyst covering the entire muscular system and perforated only at the level of the polypidian tube for the passage of the numerous tentacles.

Variations.-The micrometric variations are considerable. Smitt had already in 1872 discovered that the size of the opercula varied from 0.40 to $0.86 \mathrm{~mm}$. The figures of Harmer, 1890 , indicate much greater variations. Our specimens from the Philippines have zooecial dimensions much smaller; those from Honolulu are still smaller. It is then in the Gulf of Mexico that the species developed best and Harmer cited the large dimensions of the specimens from Jamaica. 
Biology.-According to Osburn, the zoarium encrusts shells, coral, and sponges. All our specimens were unilamellar and free; they creep over fragile, destructible, or easily detached organisms.

The ectocyst is, according to the rule, light colored; it is of the same color as the nullipores on which the zoarium is often attached; we have thus the beautiful rose-tinted specimens attached to nullipores of the same color. Moreover, "the color varies from pink to reddish brown" (Osburn).

The ovisac containing the eggs and embryos is placed in the distal portion of the ordinary (not mandibular) zooecia in the vicinity of the vestibule. The spermatic cells are dispersed in the general cavity of the two kinds of zooecia.

Because of its large dimensions, this species even when living is easily encrusted by the small species of bryozoa. The latter develop very rapidly on the ectocyst; they are not in the least disturbed by the movement of the mandibular operculum which they impede when the latter remained closed for a long time. We have several colonies dredged alive on which three or four cellules are entirely covered and rendered immobile by the small Membranipores or Cribrimorphs. The instinct of the larvae of these parasites is quite remarkable, for they appear to understand that the large animals can subsist only when in the midst of great planctonic richness.

This is a species of shallow water from 15 to 50 meters. It can live at greater depths; Ortman noted it from Japan to 320 meters and we ourselves have observed it from the Philippines at 283 and 372 meters, but these are the exceptional cases in which the specimens are rare or dead. It is very vigorous and almost universal, for it has been observed in all the oceans. It is especially equatorial, but it passes beyond the Tropics, for it is found in the Pacific as far as Japan and the Sandwich Islands. As it does not encircle a single continent, it must have found a passage of dissemination in the ancient seas. In fact, it is already known in the fossil state in the American and Australian Miocene. Perhaps our Steganoporella parvula from the lower Miocene of Bowden, Jamaica, is the primitive and ancestral variety. In Europe it is replaced by the superb Steganoporella elegans Milne Edwards, 1838, very common in all the Miocene formations.

Occurrence.-Albatross Station D. 2324 north of Cuba; $23^{\circ} 10^{\prime} 25^{\prime \prime}$ N.; $82^{\circ} 20^{\prime} 24^{\prime \prime}$ W.; 33 fms.; coral. Albatross Station 2327, north of Cuba; $23^{\circ} 11^{\prime} 45^{\prime \prime} \mathrm{N}$; $82^{\circ} 17^{\prime} 54^{\prime \prime}$ W.; 182 fms.; fine brown sand. Albatross Station D. 2365, east of Yucatan; $22^{\circ} 18^{\prime}$ $00^{\prime \prime} \mathrm{N}$.; $87^{\circ} 04^{\prime} 00^{\prime \prime} \mathrm{W}$.; $24 \mathrm{fms}$.; white rock coral. Albatross Station D. 2405, Gulf of Mexico, $28^{\circ} 44^{\prime}$ $00^{\prime \prime}$ N.; $85^{\circ} 16^{\prime} 00^{\prime \prime} \mathrm{W}$.; gray sand. 
Albatross Station D. 2639 Straits of Florida; $25^{\circ} 04^{\prime}$ $50^{\prime \prime} \mathrm{N}$.; $80^{\circ} 15^{\prime} 10^{\prime \prime} \mathrm{W}$.; $56 \mathrm{fms}$.; coral sand.

Fowey Light, 15 miles south of Miami, Fla., $40 \mathrm{fms}$.

Pliocene: Minnitimmi Creek, Bocas Island, Almirante

Bay, Panama.

Florida, 24-60 meters (Smitt); Tortugas, 24 meters (Osburn); Caribbean Sea, Pedro Bank, Jamaica, 16-19 m. (Harmer); St. Vincent (Harmer). Atlantic; Bermuda (Verril).

Geographic distribution.-Atlantic: Abrothos Island, Brazil, 32 meters. Pacific: Honolulu, 32-64 meters; Port Molle, Queensland, 18-32 meters; Torres Strait, 16-32 meters; various localities in the Malay Peninsula and the Philippines; Japan, slight depth to 320 meters; China Sea, Singapore, 19 meters; Tizard Reef, 43 meters; Borneo and Hong Kong. Indian Ocean: Almirante Island, 32-40 meters; Wasin, British East Africa, 16 meters; Chuaka, Zanzibar Channel, 3 meters.

Geologic distribution.-Miocene and Pliocene of Florida.

Plesiotypes.-Cat. Nos. 7597, 7598, 70860, U.S.N.M.

\section{STEGANOPORELLA BREVIS, new species}

Plate 32, Figure 7

Description.-The zoarium is unilamellar. The zooecia are distinct, united by their mural rim, little elongated, short, rectangular or hexagonal; the interior mural rim is wide, finely granulated, oblique; the cryptocyst is large, concave, smooth. The opesium is semielliptical, transverse, limited distally by a vestibular arch; the polypidan tube is small, median, little salient, placed between the two opesiules. The large zooecia (B) have the form of an 8 ; the opesium is very large; the distal plate is very small and reduced to an arched slit placed between the mural rim and a salient cushion.

Measurements.-Ordinary zooecia $(a)\left\{\begin{array}{l}L z=0.90 \mathrm{~mm} . \\ l z=0.60-0.70 \mathrm{~mm} .\end{array}\right.$

Opesium $\left\{\begin{array}{l}h o=0.15 \mathrm{~mm} . \\ l_{0}=0.25 \mathrm{~mm} .\end{array}\right.$

Avicularian zooecia $(B)\left\{\begin{array}{l}L z=1.05 \mathrm{~mm} . \\ l z=0.75 \mathrm{~mm} .\end{array}\right.$

Opesium $\left\{\begin{array}{l}h o=0.30 \mathrm{~mm} \\ l_{0}=0.50 \mathrm{~mm}\end{array}\right.$

Affinities. - This species is very well characterized by the form and the nature of the B zooecium with an avicularian operculum. It is smaller than Steganoporella magnilabris Busk, 1854, which is so widely distributed in the Gulf of Mexico.

Occurrence.-Pliocene: Minnitimmi Creek, Bocas Island, Almirante Bay, northwest Panama.

Holotype.-Cat. No. 70859, U.S.N.M. 


\section{Genus SIPHONOPORELLA Hincks, 1880}

SIPHONOPORELLA DUMONTI, new species

\section{Plate 7, Figure 4-7; text Figure 9}

Description.-The zoarium is free; the fronds are cylindrical, bifurcated, rarely lamellar. The zooecia are distinct, separated by a deep furrow, very elongated, rectangular; the mural rim is salient, finely crenulated; the cryptocyst is deep, flat, granular. The opesium is oval, little elongated; the polypidian tube is broad, salient, eccentric. the avicularian zooecia are long, narrow, provided with a polypidian tube; the mandible is large, spatulated. There is a salient tubercle in each of the interzooecial angles.

Measurements.-Opesium $\left\{\begin{array}{l}h o=0.30 \mathrm{~mm} . \\ l_{0}=0.20 \mathrm{~mm} .\end{array}\right.$ Zooecia $\left\{\begin{array}{l}L z=0.60 \mathrm{~mm} \\ l z=0.36 \mathrm{~mm}\end{array}\right.$

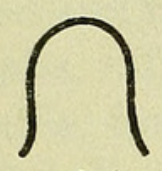

A

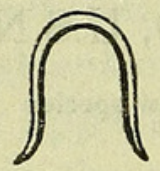

B

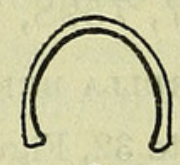

C

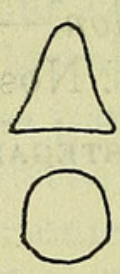

D

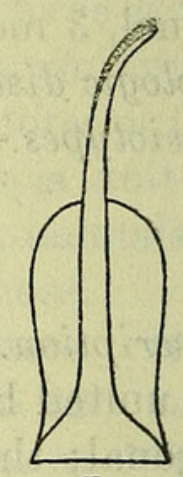

E

Fig. 9.-Siphonoporella dumonti, new species. $A$ - $C$. Different aspects of the EPERCULAR VALVE. IN $A$ THE SCLERITE OF THE VALVE IS EXACTLY SUPERPOSED ON THE EXTERIOR SCLERITE OF THE ECTOCYST. D. THE TWO PORTIONS OF AN AVICULARIAN MANDIBLE. THEY ARE UNITED BY TWO Strong lateral SClerites. $E$. AN ORDINARY ONYCHOCELLARIUM, $\times 85$

Structure.-The internal structure is that of a simplified Steganoporella; there is only an oblique and short polypidian tube. The opercular valve is simple, as those of Membranipores, and isolated from the mural rim. It is inserted exactly into the ectocystal sclerite which forms the aperture.

The B zooecia have also a polypidian tube, but their opercular valve is transformed into a true mandible of a size altogether equal to that of the cryptocyst and of the same form. When it is lowered it is exactly bordered by the mural rim. It has a mandibular structure very close to that of Steganoporella. In Labiopora the differentiation is complete, for here the B zooecia are transformed into true interzooecial avicularia.

Affinities.-This species differs from Siphonoporella granulosa in its free zoarium, its rectangular zooecia, and the much smaller zooecial, dimensions. The dimensions of the opercular valve are quite variable. 
Named in honor of Gen. G. A. L. Dumont, the distinguished military attache of the French Embassy in the United States, who has done so much for the encouragement of good feeling between France and the United States.

Occurrence.-Albatross Station D. 2405, Gulf of Mexico; $28^{\circ} 45^{\prime}$ $00^{\prime \prime} \mathrm{N}$.; $85^{\circ} 02^{\prime} 00^{\prime \prime} \mathrm{W}$.; $30 \mathrm{fms}$.; gray sand, broken coral.

Cotypes.-Cat. No. 7592, U.S.N.M.

\section{SIPHONOPORELLA GRANULOSA, new species}

Plate 8, Figure 1

Description.-The zoarium encrusts dead shells and corals. The zooecia are distinct, separated by a small furrow, large, elongated, elliptical; the mural rim is thick, salient, crenulated. The opesium is large, semielliptical; the polypidian tube is wide, oblique, salient, with an oblique orifice; the cryptocyst is flat, deep, granular. The B zooecia are long, narrow; the opesium is elliptical, nonterminal; the polypidian tube is visible but not salient.

$$
\begin{array}{r}
\text { Measurements.-Opesium }\left\{\begin{array}{l}
h o=0.25 \mathrm{~mm} . \\
l o=0.30 \mathrm{~mm} .
\end{array}\right. \\
\text { Zooecia }\left\{\begin{array}{l}
L z=0.70 \mathrm{~mm} . \\
l_{z}=0.50 \mathrm{~mm} .
\end{array}\right.
\end{array}
$$

Diameter of polypidian tube $=0.16 \mathrm{~mm}$.

Length of B zooecia $=0.85 \mathrm{~mm}$.

Structure.-The structure is identical with that of Siphonoporella dumonti. The mandible of the B zooecia exactly and entirely covers the cryptocyst when it is lowered; its form and its size are then regulated by the frontal calcification.

Occurrence.-Albatross Station D. 2405, Gulf of Mexico; $28^{\circ} 45^{\prime}$ $00^{\prime \prime} \mathrm{N}$.; $85^{\circ} 02^{\prime} 00^{\prime \prime} \mathrm{W}$.; $30 \mathrm{fms}$.; gray sand, broken coral.

Albatross Station D. 2639, Straits of Florida; $25^{\circ} 04^{\prime}$ $50^{\prime \prime} \mathrm{N}$.; $80^{\circ} 15^{\prime} 10^{\prime \prime} \mathrm{W}$.; $56 \mathrm{fms}$.; coral sand.

Fowey Light, 15 miles south of Miami, Fla., $40 \mathrm{fms}$.

Pliocene: Minnitimmi Creek, Bocas Island, Almirante Bay, Panama.

Holotype.-Cat. No. 7593, U.S.N.M.

Family ASPIDOSTOMIDAE Jullien, 1888

\section{Genus MOLLIA Lamouroux, 1821}

MOLLIA PATELLARIA Smitt, 1873

Plate 8, Figures 2, 3; text Figure 10

1873. Mollia patellaria Smits, Floridan Bryozoa. Kongl. Svenska Vetenskaps-Akademiens Handlingar, vol. 11, no. 4, p. 12, pl. 2, fig. 72. 
Measurements.-Opesium $\left\{\begin{array}{l}h_{o}=0.12 \mathrm{~mm} . \\ l o=0.15 \mathrm{~mm} .\end{array}\right.$

$$
\text { Zooecia }\left\{\begin{array}{l}
L_{z}=0.40 \mathrm{~mm} . \\
l_{z}=0.30 \mathrm{~mm} .
\end{array}\right.
$$

Structure.-The opesium is trifoliate; the two lateral condyles serve as a support to the opercular valve. The latter is very simple and analogous to that in the Membranipores. The proximal portion of the opesium which it does not cover probably serves as a passage for the opesiular muscles, but we still have no material proof of their presence and the genus could just as well be classed next to Amphiblestrum.

The zooecia are disjoined; a single point of junction unites them to each of the adjacent zooecia. On the inferior face they are sur-

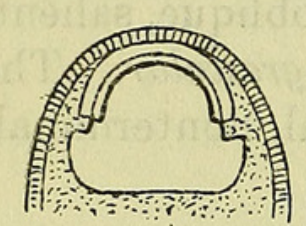

Fig. 10.-Mollia PATELLARIA SMITT, 1873. DRAWING OF A ZOOECIUM, $\times 85$, S H O W IN G THE APERTURAL SCLERITE SOMEWHAT REMOVED FROM THE MURAL RIM AND SUPPORTED WITH THE OPERCULAR SCLERITE ON THE TWO OPESIAL CONDYLES

Occurrence.-Albatross Station D. 2405, Gulf of Mexico; $28^{\circ} 45^{\prime}$ $00^{\prime \prime}$ N.; $85^{\circ} 02^{\prime} 00^{\prime \prime}$ W.; 30 fms.; gray sand, broken coral. Florida, 58 meters (Smitt).

Plesioiype.-Cat. No. 7559, U.S.N.M.

\section{Family ARACHNOPUSIIDAE Jullien, 1888}

\section{Genus EXECHONELLA Canu and Bassler, 1927}

\section{EXECHONELLA PUMICOSA, new species}

Plate 14, Figure 1; text Figure 11a

Description.-The zoarium encrusts shells. The zooecia are distinct, separated by a deep furrow, very large, oval, somewhat elongated; the frontal is convex, very porous; each pore (or lacuna) is surrounded by a salient peristome. The aperture is large, suborbicular, a little elongated or a little transverse, formed of a large anter separated from a smaller poster by two lateral indentations; two small lamellae arrest the movements of the operculum; the peristome is thick salient. One of the peripheral pores is transformed sometimes into a small round avicularium. 
Measurements.-Aperture $\left\{\begin{array}{l}h a=0.20 \mathrm{~mm} \\ l a=0.20 \mathrm{~mm} .\end{array}\right.$

$$
\text { Zooecia }\left\{\begin{array}{l}
L z=0.85 \mathrm{~mm} . \\
l z=0.65-0.75 \mathrm{~mm} .
\end{array}\right.
$$

Variations.-The operculum is never rigorously orbicular; it is somewhat elongated or a little transverse; it always bears two large very thick chitinous bands; their inferior extremity is exactly at the level of the indentations of the aperture which mark the axis of rotation of the operculum. This arrangement is quite visible on our photograph, but because of desiccation, the operculum is inverted, the poster being visible; when the polypide extends its tentacles, the anter becomes erect and the poster is embedded in the zooecium. The operculum is very fragile and its movements are limited by two small lamellae (proximal and distal) quite visible at the bottom of the peristome. The size of the operculum renders its preparation very difficult; it is deformed and torn very easily.

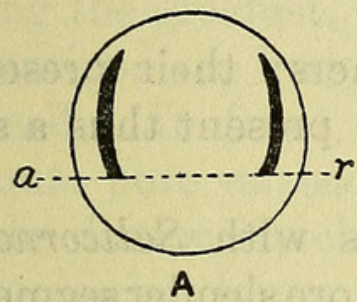

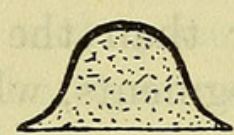

B
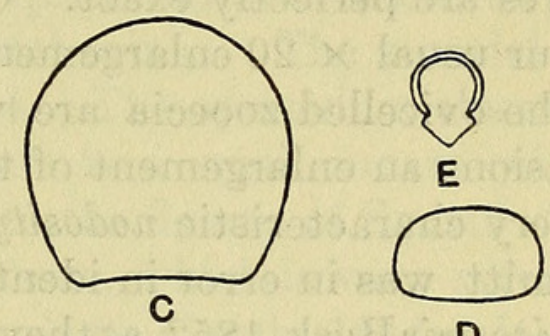

D

Fig. 11.-Opercular. Exechonella pumicosa, new species. A. Somewhat elongated Operculum, $\times 85$, ShOWING the axis of rotation $(a r)$ B. PUellina floridana SMitt 1873. A MUCH CHITINIZED OPERCULUM, $\times$ 85. C. Figularia? AMPLA, NeW SPECIEs. Operculum, $\times 85 . \quad D$. Stenopsis fenestrata Smitt, 1875 . Operculum $\times 85$. Trypostega venusta Norman. Operculum, $\times 85$

The cellule $a$ of our photograph shows that the operculum is not attached either to the subadjacent ectocyst or to the compensatrix. We do not know yet if the latter exists on the interior of the zooecium under the ectocyst, or perhaps if the space between the frontal and the ectocyst replaces it in order to form a special hydrostatic system.

The similarity of the operculum with that of the Hippoporae seems to indicate that there is really an interior compensatrix, but the anatomical study alone can furnish positive arguments.

We have found two species of this genus in the American Claibornian and Jacksonian but the geographic distribution of the genus is much greater. We have noted it in our monograph on the Philippine bryozoa as present in France (Lutetian, Aquitanian, Burdigalian) and in Australia (Miocene). Exechonella pumicosa is the third recent species which we have recognized.

Affinities.--This species differs from Exechonella magna MacGillivray, 1895, in its smaller zooecial dimensions and in its much more porous frontal.

Occurrence.-Fowey Light, 15 miles south of Miami, Fla.; $40 \mathrm{fms}$. Holotype.-Cat. No. 7838, U.S.N.M. 


\title{
Division PSEUDOSTEGA Levinsen, 1909
}

\section{Family CELLARIIDAE Hincks, 1880}

\section{Genus CELLARIA Lamouroux, 1812}

CELLARIA NODOSA, new name

\author{
Plate 8, Figures 9, 10
}

1873. Cellaria tenuirostris SmitT (not Busk, 1852), Floridan Bryozoa. Kongl. Svenska Vetenskaps-Akademiens Handlingar, vol. 11, no. 4, p. 4, pl. 1, fig. 57-59.

Measurements. - Aperture $\left\{\begin{array}{l}h a=0.05 \mathrm{~mm} . \\ l_{a}=0.08-0.09 \mathrm{~mm} .\end{array}\right.$

$$
\text { Zooecia }\left\{\begin{array}{l}
L z=0.60 \mathrm{~mm} . \\
l_{z}=0.20 \mathrm{~mm} .
\end{array}\right.
$$

Affinities.-This species is admirably illustrated by Smitt whose figures are perfectly exact. Our photographs only indicate the size at our usual $\times 20$ enlargements.

The ovicelled zooecia are wider than the others; their presence occasions an enlargement of the segments, which present thus a sort of very characteristic nodosity.

Smitt was in error in identifying his specimens with Salicornaria tenuirostris Busk, 1852 , as they differ in the much more slender segments swelling in places, in the enlarged form of the ovicelled zooecia, in the lozenge-shaped and nonrhomboidal form of the avicularia, in the presence of a canalicule in the avicularium, and in a much smaller aperture $(0.08$ and not 0.13$)$. We have therefore given another name to this charming species. It is regrettable that it did not preserve its chitinous appendages.

Occurrence.-Albatross Station D. 2388, Gulf of Mexico; $29^{\circ} 24^{\prime}$ $30^{\prime \prime} \mathrm{N}$.; $88^{\circ} 01^{\prime} 00^{\prime \prime} \mathrm{W}$.; $35 \mathrm{fms}$.; yellow sand, black specks.

Caribbean Sea off Carysfort reef, 84 meters; west of Tortugas, 110 meters (Smitt).

Pliocene: Minnitimmi Creek, Bocas Island, Almirante Bay, Panama.

Holotype.-Cat. No. 7472, U.S.N.M

\section{CELlaria SINUOSA Hassall, 1842}

This is the first time that this beautiful species, very common in Europe, has been found in the vicinity of the American coasts. We do not believe that we are deceived in our determination.

Occurrence.-Albatross Station D. 2004. Atlantic Ocean, east of Cape Hatteras, $37^{\circ} 19^{\prime} 45^{\prime \prime}$ N.; $74^{\circ} 26^{\prime} 06^{\prime \prime}$ W.; 102 fms.; green mud, shells. 


\section{Suborder AscopHORA Levinsen}

Family COSTULAE Jullien, 1888. (Family CRIBRILINIDAE Hincks, 1880)

\section{Genus PUELLINA Jullien, 1886}

PUEllina RAdiata, Moll, 1803

Plate 10, Figure 11

1873. Cribrilina radiata Smitr, Floridan Bryozoa. Kongl. Svenska Vetenskaps-Akademiens, Handlingar, vol. 11, p. 22, pl. 5, figs. 107, 108.

1920. Puellina radiata CANU and BASsler, North American Early Tertiary Bryozoa. Bull. 106, U. S. National Museum, p. 295. pl. 41, figs. 14-18.

Measurements.-Aperture $\left\{\begin{array}{l}h a=0.06 \mathrm{~mm} . \\ l a=0.08 \mathrm{~mm} .\end{array}\right.$

$$
\text { Zooecia }\left\{\begin{array}{l}
L z=0.50 \mathrm{~mm} \\
l_{z}=0.42 \mathrm{~mm}
\end{array}\right.
$$

Variations.-The measurements are quite variable, those we give being the greatest. There are five distal spines. The zooecial deformations are frequent and quite great. The operculum closes the ovicell. In front of the aperture there is a small mucro with a minute pore on each side conforming to the figures of Smitt. This is the distinctive characteristic of this form, which is very rare. It is somewhat larger than the form innominata Couch, 1844. It does not correspond altogether to Puellina radiata as Norman, 1909, limited it, for this author indicates the inconstant presence of a lunate pore before the aperture.

Biology.-Our specimens encrust corals. They were in reproduction and fixation May 1, 1884.

Occurrence.-Albatross Station D. 2169, off Habana, Cuba; $23^{\circ} 10^{\prime}$ $28^{\prime \prime}$ N.; $82^{\circ} 20^{\prime} 27^{\prime \prime}$ W.; 78 fms.; coral.

Fowey Light, 15 miles south of Miami, Fla.; $40 \mathrm{fms}$. Pliocene: Minnitimmi Creek, Bocas Island, Almirante Bay, Panama.

\section{PUELLINA IN NOMINATA Couch, 1844}

Plate 14, Figure 2

1873. Cribrilina innominata SмIтt, Floridan Bryozoa. Kongl. Svenska Vetenskaps-Akademiens, Handlingar, vol. 11, p. 22, pl. 5, figs. 109, 110.

Measurements.-Aperture $\left\{\begin{array}{l}h a=0.06 \mathrm{~mm} . \\ l a=0.04 \mathrm{~mm} .\end{array}\right.$

$$
\text { Zooecia }\left\{\begin{array}{l}
L z=0.30-0.36 \mathrm{~mm} . \\
l z=0.30 \mathrm{~mm} .
\end{array}\right.
$$

Variations.-This form is the more frequent; it offers the same aspects as specimens from the Philippines but with smaller dimen- 
sions. It is well characterized by its median pore placed in the vicinity of the aperture and by the beautiful lateral tuberosities which surround each zooecium like a necklace. The median pore is often invisible and buried in the peristome. Frequently the lateral tuberosities are much attenuated and the costules much less calcified. The interzooecial avicularium is frequent, very long, acuminated, and salient in front of the zooecial plane.

According to Norman, 1909, this form differs from the typical form only in its much smaller dimensions, its more salient costules, and in its less acuminate avicularium. Smitt, 1872 , placed here all the specimens ornamented with a lunate pore. The variations of the two forms being quite large, it is really impossible to distinguish them specifically, and we therefore follow the opinion of Waters.

The operculum closes the ovicell. The costules are covered by the ectocyst. On the interior the costules are not visible. Only the lumen pores, radially arranged, appear as tremopores.

Biology.-Our specimens encrust nullipores, dead shells, and corals. The living specimens were in reproduction March 15, 1885.

We have shown in our work on the Philippine Bryozoa that this species is in reproduction continuously during the entire year.

Occurrence.-Albatross Station D. 2320, north of Cuba; $23^{\circ} 10^{\prime}$ $39^{\prime \prime}$ N.; $82^{\circ} 18^{\prime} 48^{\prime \prime}$ W.; 130 fms.; fine coral.

Albatross Station D. 2405, Gulf of Mexico; $28^{\circ} 45^{\prime}$ $00^{\prime \prime} \mathrm{N}$.; $85^{\circ} 02^{\prime} 00^{\prime \prime} \mathrm{W}$.; $30 \mathrm{fms}$.; gray sand, broken coral.

Albatross Station D. 2639 , Straits of Florida; $25^{\circ} 04^{\prime}$ $50^{\prime \prime}$ N.; $80^{\circ} 15^{\prime} 10^{\prime \prime}$ W.; 56 fms.; coral sand.

Albatross Station D. 2672, Atlantic, east of Georgia; $31^{\circ} 31^{\prime} 00^{\prime \prime}$ N.; $79^{\circ} 05^{\prime} 00^{\prime \prime} \mathrm{W}$.; 277 fms.; coarse brown sand.

\section{PUELLINA FLORIDANA Smitt, 1873}

Plate 14, Figures $3-7$; text Figure $11 b$

1873. Cribrilina figularis Smiтt, Floridan Bryozoa. Kongl. Svenska Vetenskaps-Akademiens, Handlingar, vol, 11, p. 23, pl. 5, fig. 112.

1873. Cribrilina figularis var. floridana SмIтт, Kongl. Svenska VetenskapsAkademiens, Handlingar, p. 23, pl. 5, fig. 111.

?1879. Lepralia elegantissima Seguenza, Le formazioni terziarie della Provincia di Reggio (Calabria), Reale Accademia dei Lincei, Memoria della di Science, etc., ser. 3, vol. 6, p. 83, pl. 8, fig. 11.

?1901. Cribrilina (Figularia) elegantissima Neviani, Briozoi neogenici della Calabrie. Paleontographia Italica, vol. 6, p. 173, (sep. 59), pl. 1, fig. 28.

1914. Cribrilina floridana Osburn, Bryozoa of the Tortugas Islands. Publication Carnegie Institution, Washington, No. 182, p. 195. 
Our specimen was living but not ovicelled. It corresponds to Figure 112 of Smitt.

$$
\begin{gathered}
\text { Measurements.-Aperture }\left\{\begin{array}{l}
h a=0.07 \mathrm{~mm} . \\
l a=0.10-0.13 \mathrm{~mm} . \\
0.15 \mathrm{~mm} .(\text { after Smitt) }
\end{array}\right. \\
\text { Zooecia }\left\{\begin{array}{l}
L z=0.42-0.46 \mathrm{~mm} . \\
l_{z=0.36 \mathrm{~mm} .}
\end{array}\right.
\end{gathered}
$$

There are about six pairs of dietellae. In transparency the coscules are indistinct and the lumen pores are very numerous; the median line of suture is visible; the lunate pore is often surmounted by a kind of very narrow rimule (indicated on fig. 111 of Smitt). Un the interior the costules are not visible. The semicircular operculum is well chitinized and of a brownish color (Osburn). We figure it and it is bordered with a thick sclerite.

We are the third observers of this species. Nevertheless, its strucure is not yet well known, for the specimens found are very rare and ıncomplete. They encrust shells and corals.

Occurrence.-Albatross Station D. 2405, Gulf of Mexico; $28^{\circ} 45^{\prime}$ $00^{\prime \prime} \mathrm{N}$.; $85^{\circ} 02^{\prime} 00^{\prime \prime} \mathrm{W}$.; $30 \mathrm{fms}$.; gray sand, broken coral.

Florida, 47, 58 meters (Smitt); Tortugas, 8-34 meters (Osburn).

\section{Genus FIGULARIA Jullien, 1885}

FIGULARIA (?) AMPLA, new species

Plate 14, Figure 8; text Figure 11c

Description.-The zoarium encrusts shells. The zooecia are distinct, separated by a deep furrow, very large and little elongated, elliptical; the frontal is very convex and formed of six pairs of very broad costules, adjacent; the costules are separated by very small linear lacunae attached to a median and salient suture line. An elliptical line of lacunae a little larger outline on the frontal an elegant elliptical diagram. The aperture is large, a little transverse; two small lateral indentations separate a large semielliptic anter from a small concave poster. The ovicell is large, smooth, carinated, hyperstomial, opened by a very narrow slit.

$$
\begin{array}{r}
\text { Measurements.-Aperture }\left\{\begin{array}{l}
h a=0.26 \mathrm{~mm} \\
l a=0.30 \mathrm{~mm} .
\end{array}\right. \\
\text { Zooecia }\left\{\begin{array}{l}
L z=1.5 \mathrm{~mm} . \\
l z=1.0 \mathrm{~mm} .
\end{array}\right.
\end{array}
$$

Structure.-The operculum is yellow and very chitinous; it probably closes the ovicell, but we have not been able to make direct observation. Our two specimens are without the ectocyst. We have 
not seen the internal ectocyst. Our conclusions on the structure of this beautiful species are then very insufficient and we are not able to class it accurately. It is by the simple exterior aspect of the frontal that we introduce it doubtfully and provisionally into the genus Figularia.

Occurrence.-Albatross Station D. 2167, off Habana, Cuba; $23^{\circ} 10^{\prime}$ $40^{\prime \prime}$ N.; $82^{\circ} 20^{\prime} 30^{\prime \prime}$ W.; 201 fms.; coral.

Holotype.-Cat. No. 7494, U.S.N.M.

Family HIPPOTHOIDAE Levinsen, 1909

\section{Genus HIPPOTHOA (Lamouroux, 1821) Hincks, 1880}

HIPPOTHOA EBURNEA Smitt, 1873

1873. Gemellipora eburnea Sмiтt, Floridan Bryozoa. Kongl. Svenska Vetenskaps-Akademiens Handlingar, vol. 11, no. 4, p. 35, pl. 9, fig. 178 (not pl. 7, fig. 152-156).

Measurements.-Aperture $\left\{\begin{array}{l}h a=0.06 \mathrm{~mm} . \\ l a=0.04 \mathrm{~mm} .\end{array}\right.$

$$
\text { Zooecia }\left\{\begin{array}{l}
L z=0.40 \mathrm{~mm} \\
l_{z}=0.14-0.16 \mathrm{~mm}
\end{array}\right.
$$

Variations.-The length of the zooecium is quite variable; with the caudal portion it often measures $0.60-0.70 \mathrm{~mm}$., but it may be elongated much more and double this length.

This is a very fragile species and, although it is not rare, it is difficult to find a well-preserved zoarium for the frontal is often broken. It chooses, moreover, for its development, sheltered places, the interior of dead shells, the inferior face of Cellepores, the base of arborescent corals, the folds of nullipores, etc.

One must not confuse this species with the creeping portions of Pasythea eburnea Smitt, 1872. We can not explain Smitt's confusion, for this species has neither the same dimensions nor the same apertural form.

Occurrence.-Albatross Station D. 2317 , north of Cuba; $24^{\circ} 25^{\prime}$ $45^{\prime \prime} \mathrm{N}$.; $81^{\circ} 46^{\prime} 45^{\prime \prime} \mathrm{W}$.; $45 \mathrm{fms}$.; coral.

Albatross Station D. 2362 , east of Yucatan; $22^{\circ} 08^{\prime}$ $30^{\prime \prime} \mathrm{N}$.; $86^{\circ} 53^{\prime} 30^{\prime \prime} \mathrm{W}$.; 25 fms.; coral sand.

Albatross Station D. 2405, Gulf of Mexico; $28^{\circ} 45^{\prime}$ $00^{\prime \prime} \mathrm{N}$.; $85^{\circ} 02^{\prime} 00^{\prime \prime} \mathrm{W}$.; $30 \mathrm{fms}$.; gray sand, broken coral.

Albatross Station D. 2672, Atlantic, east of Georgia; $31^{\circ} 31^{\prime} 00^{\prime \prime} \mathrm{N}$.; $79^{\circ} 05^{\prime} 00^{\prime \prime} \mathrm{W}$.; 277 fms.; coarse brown sand. Florida, 194 meters (Smitt). 


\section{HIPPOTHOA DIVARICATA Lamouroux, 1821}

\section{Plate 28, Figure 7}

1918. Hippothoa divaricata W ATERs, Some collections of the Littoral Marine Fauna of the Cape Verde Islands. Journal Linnean Society, Zoology, vol. 34, p. 20 (Synonymy).

This cosmopolitan species has been noted at only one locality in our Gulf of Mexico dredgings. Miss Jelly's catalogue and Water's work cited above give its complete bibliography.

Occurrence.-Albatross Station D. 2650 , Bahama Islands; $23^{\circ} 34^{\prime}$ $30^{\prime \prime}$ N.; $76^{\circ} 34^{\prime} 00^{\prime \prime}$ W.; 369 fms.

Plesiotype.-Cat. No. 7523, U.S.N.M.

\section{Genus TRYPOSTEGA Levinsen, 1909}

\section{TRYPOSTEGA VENUSTA Norman, 1864}

Plate 8, Figures 5, 6; text Figure $11 e$

1920. Trypostega venusta CANU and Bassler, North American Early Tertiary Bryozoa. Bull. 106, U. S. National Museum, p. 330, pl. 85, fig. 15, 16. (Bibliography and geographic distribution.)

Measurements.-Zooecia (distant from border) $\left\{\begin{array}{l}L z=0.40 \mathrm{~mm} \text {. } \\ l_{z}=0.26 \mathrm{~mm} .\end{array}\right.$

Aperture $\left\{\begin{array}{l}h a=0.10 \mathrm{~mm} . \\ l a=0.06 \mathrm{~mm} .\end{array}\right.$

Marginal zooecia $\left\{\begin{array}{l}L_{z}=0.50-0.60 \mathrm{~mm} . \\ l_{z}=0.30 \mathrm{~mm} .\end{array}\right.$

$$
\text { Aperture }\left\{\begin{array}{l}
h a=0.10 \mathrm{~mm} . \\
l a=0.06 \mathrm{~mm} .
\end{array}\right.
$$

Variations.-In our bibliography of 1920 we omitted the variety inornata Smitt, 1872 (not Gabb and Horn). We are now convinced that this is indeed the same species in spite of the difference in size; in fact, the species is quite variable in its micrometric dimensions, the marginal zooecia of the large colonies being much larger than the others. The operculum presents the same variations; it closes the ovicell.

Biology. - The specimens encrust bryozoa (Steganoporella, Stylopoma), shells, corals (Oculina), hydroids, and nullipores; they prefer smooth surfaces. They are light colored, but the operculum is slightly yellow. Our specimens were in reproduction and fixation from January to March; it is probable that they reproduce throughout the year.

This species is indifferent to bathymetric variations, but it prefers depths from 10 to 100 meters. It has been observed in the Atlantic as far as the fiftieth parallel. 
Occurrence.-Albatross Station D. 2167, off Habana, Cuba; $23^{\circ}$ $10^{\prime} 40^{\prime \prime} \mathrm{N}$.; $82^{\circ} 20^{\prime} 30^{\prime \prime} \mathrm{W}$.; $201 \mathrm{fms}$; coral.

Albatross Station D. 2334, north of Cuba; $23^{\circ} 10^{\prime}$ $42^{\prime \prime}$ N.; $82^{\circ} 18^{\prime} 24^{\prime \prime}$ W.; 67 fms.; white coral.

Albatross Station D. 2639 , Straits of Florida; $25^{\circ} 04^{\prime}$ $50^{\prime \prime} \mathrm{N}$.; $80^{\circ} 15^{\prime} 10^{\prime \prime} \mathrm{W}$.; $56 \mathrm{fms}$.; coral sand. Albatross Station D. 2405, Gulf of Mexico; $28^{\circ} 45^{\prime}$ $00^{\prime \prime} \mathrm{N}$.; $85^{\circ} 02^{\prime} 00^{\prime \prime} \mathrm{W}$.; $30 \mathrm{fms}$.; grey sand, broken coral.

Florida, 41-97 meters (Smitt); Tortugas, 8-24 meters (Osburn).

Plesiotypes.-Cat. Nos. 7608, 7609, U.S.N.M.

\section{Family PETRALIIDAE Levinsen, 1909}

\section{Genus PETRALIELla Canu and Bassler, 1927}

\section{PETRALIELLA BISINUATA Smitt, 1873}

Plate 16, Figures 1-5; Plate 33, Figure 4; text Figures $12 a-h$

1873. Escharella bisinuata Sмiтt, Floridan Bryozoa. Kongl. Svenska Vetenskaps-Akademiens Handlingar, vol. 11, p. 59, pl. 12, fig. 229.

1909. Petralia bisinuata Levinsen, Studies on the Cheilostomatous Bryozoa, pp. $350,351$.

1914. Petralia bisinuata Osburn, Bryozoa of the Tortugas Islands. Publication Carnegie Institution, Washington, No. 182, p. 217.

Measurements.-Aperture $\left\{\begin{array}{l}h a=0.24-0.25 \mathrm{~mm} \\ l a=0.26 \mathrm{~mm} .\end{array}\right.$

$$
\text { Zooecia }\left\{\begin{array}{l}
L z=0.90-1.15 \mathrm{~mm} \\
l_{z}=0.50-0.55 \mathrm{~mm}
\end{array}\right.
$$

Variations.-Smitt spoke only of a single avicularium; there are generally two on our specimens; rarely are they equal, one being larger than the other; these are the zooecial avicularia. Rarely there are two avicularia on the shield; then there are no longer any large avicularia. This irregularity is disconcerting and does not permit us to judge the function of these small organs.

The cribriform area is a rather deep concavity surrounded by a peristome, closed by the ectoyst, where there are no radicells and placed below the aperture. It is frequently accompanied by one or two smaller radicular pores. The frontal structure is that of a tremocyst.

This is a rare species of which we were able to prepare the complete operculum. It is often detached from the compensatrix, but frequently the chitinization stops at the axis of rotation. The opercula of the ovicelled zooecia are a little larger. The chitinized band which surrounds the operculum is generally narrow, but it can become enlarged às in the genus Petralia. 
The radicells form a true passageway between the colonies and the algal substratum; they are fragile, hollow, terminated in a brush.

The mandibles are very thin and transparent. The zoarium is unilamellar, very often cylindrical, for it encrusts algae. It may also creep over nullipores (Smitt).

Biology. - The color in life is a bright vermillion (Osburn). The calcareous skeleton is much less pigmented than the ectocyst. The operculm is light colored. The giant species have not much vitality.

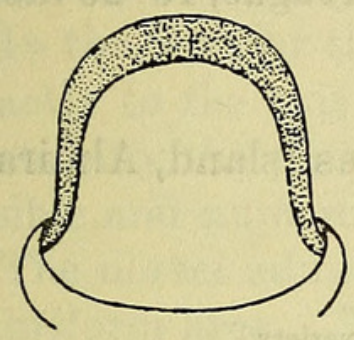

A

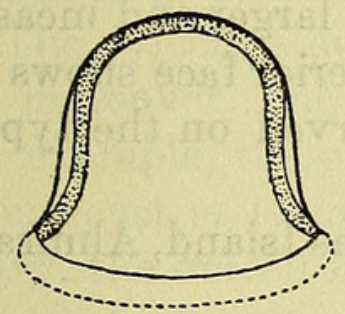

D
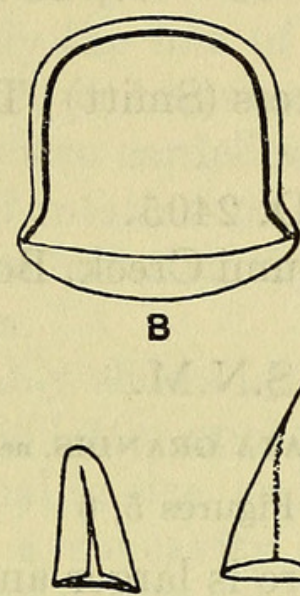

E

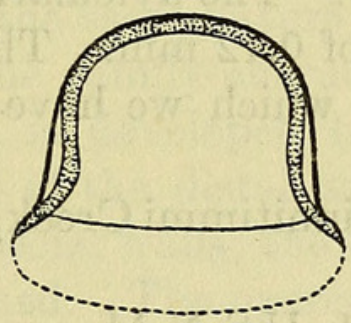

1

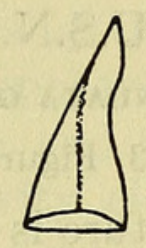

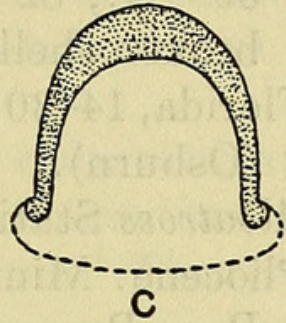

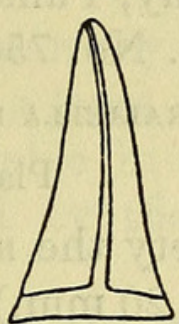

G

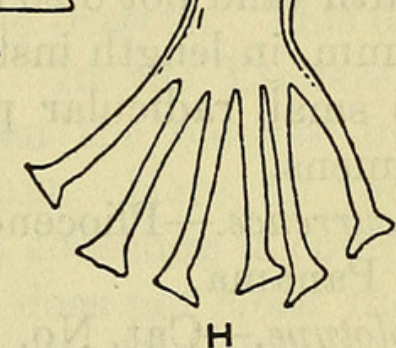

Fig. 12.-Genus Petraliella, new genus. A-I. Petraliella bisinuata Smitt, 1873. A. Operculum, $\times 85$, With BROAD, Chitinized MARginal BaNd. $B$. ANOTHER OPERCULUM, $\times 85$, WITH NARROW MARGINAL BAND. C. ANOTHER FORM OF OPERCULUM, $\times 85$. $D$. OPERCULUM, $\times 85$, in WHich THE PROXIMAL ARTICULATION With THE COMPENSATRIX IS visible. $E, F, G$. Three Mandibles, $\times 85 . H$. Radicel of this SPECIES, $\times 85$. $I$. Petraliella Marginata, NeW SPEcies. OPERculum, $\times 85$, with Narrow Marginal band

For example, on the same alga a larva of Cellepora was fixed near a Petraliella larva; the two colonies are well developed at first, but the Cellepora stopped the Petraliella and became superposed upon it. Likewise in the interior of a tube of Petraliella a larva of Smittina trispinosa was affixed; it developed normally in pursuing completely the radicular system which did not disturb it at all. When they are useless by death or putrefaction of the substratum, the radicells disappear; also the interior face serves as a refuge for small parasitic species such as Hippothoa, which find here an excellent refuge to shelter their extreme fragility. We have made the same observations on Petraliella vorax, new species, of the Philippines, where we were able to determine the same parasites. 
Our living specimens were in reproduction January 30 and March 19,1885 . Up to the present the species has been dredged only from depths of water below 42 meters.

Occurrence.-Albatross Station D. 2362, east of Yucatan; $22^{\circ} 08^{\circ}$ $30^{\prime \prime} \mathrm{N}$.; $86^{\circ} 53^{\prime} 30^{\prime \prime} \mathrm{W}$.; 25 fms.; coral sand.

Albatross Station D. 2363 , east of Yucatan; $22^{\circ} 07^{\prime}$ $30^{\prime \prime}$ N.; $87^{\circ} 06^{\prime} 00^{\prime \prime}$ W.; $21 \mathrm{fms}$; ; coral.

Albatross Station D. 2414, Gulf of Mexico; $25^{\circ} 04^{\prime}$ $30^{\prime \prime} \mathrm{N}$.; $82^{\circ} 59^{\prime} 15^{\prime \prime} \mathrm{W}$.; 26 fms.; fine white sand, broken shells.

Florida, 14-30 meters (Smitt); Tortugas, 16-29 meters (Osburn).

Albatross Station D. 2405.

Pliocene: Minnitimmi Creek, Bocas Island, Almirante Bay, Panama.

Plesiotypes.-Cat. No. 7568, U.S.N.M.

PETRALIELLA BISINUATA GRANDIS, new variety

Plate 33, Figures 5, 6

In this new variety the aperture is larger and measures $0.30 \mathrm{~mm}$. in width (and not $0.20 \mathrm{~mm}$.). The avicularia are larger and measure $0.15 \mathrm{~mm}$. in length instead of $0.12 \mathrm{~mm}$. The inferior face shows the same small radicular pores which we have observed on the typical specimens.

Occurrence.-Pliocene: Minnitimmi Creek, Bocas Island, Almirante Bay, Panama.

Holotype.-Cat. No. 70851, U.S.N.M.

PETRALIELla Marginata, new species

Plate 16, Figures 6-11; text Figure $12 i$

Description.-The zoarium is free, unilamellar, formed of more or less expanded fronds. The zooecia are distinct, separated by a salient thread, large, elongated, rectangular; the shield is incomplete and is not developed above the aperture; it is broad inferiorily and bears laterally two small avicularia; the frontal is flat, perforated by large tremopores, often coalescent, and ornamented laterally with short interareolar costules. The aperture is semicircular, somewhat elongated or a little transverse; two very short cardelles, placed very low, separate a very large anter from a very small poster; the proximal border is straight and finely serrate. The ovicell is very large, globular, with minute perforations; it is hyperstomial, buried in the distal zooecium closed by the operculum and bordered by a thin thread. The large avicularium is placed laterally in the neighborhood of the aperture below a small apertural avicularium; it is oblique, triangular, very elongated, with unguiculate beak and provided with a pivot. The inner face of the zoarium bears distally on each zooe- 
cium a large orbicular cribriform area closed by the ectocyst. It is a radicular septule.

$$
\begin{gathered}
\text { Measurements. - Aperture }\left\{\begin{array}{l}
h a=0.22-0.25 \mathrm{~mm} . \\
l a=0.25 \mathrm{~mm} .
\end{array}\right. \\
\text { Zooecia }\left\{\begin{array}{l}
L z=1.00 \mathrm{~mm} . \\
l z=0.65-0.70 \mathrm{~mm} .
\end{array}\right.
\end{gathered}
$$

Structure.-The operculum is light colored and bell-shaped. The marginal band is very narrow; the proximal border is indecisive, for it is attached to the compensatrix. We are obliged, in order to figure it, to indicate only the line of rotation. Like the aperture, the operculum is elongated or transverse.

In the interior the two cardelles are quite visible; they correspond exactly to the axis of rotation of the operculum, which also represents only the portion covering the anter. The tremopores are quite visible and numerous.

The dorsal admirably shows by transparency the structure of the cribriform area. The latter appears as a large multiporous septule. The pores are unequal in size and variable in number (10 to 20). Exteriorily there is a concavity closed by the ectocyst and from which large radicells sometime spring.

The ovicell is not of the same nature as the frontal. This feature is, moreover, one of the family characters. In the Escharellidae, for example, the ovicell is developed between the olocyst and the pleurocyst or tremocyst of the distal zooecium. Here, on the contrary, the ovicell has special walls; the distal zooecium is completely calcified when it is formed. The operculum does not close the ovicell throughout its life, but in opening it permits the passage of the eggs in closing exactly the orifice of the ovicell. However, on our dissected specimens we are not positively certain of the exactness of this observation.

Variations.-The small apertural avicularia are very constant. They are elliptical, but their orientation is quite variable. They must exercise the function of the oral glands which do not exist in this family. The large avicularium is zooecial; its presence is inconstant and its dimensions are variable. When one of the small apertural avicularia becomes very large, the large avicularium does not develop.

The zoarium often has the form of a hollow horn. The radicells are rarely present on the interior face. The latter is almost always incrusted by small species of bryozoa and notably by Gemellipora eburnea Smitt, 1872, which thus finds safe shelter to protect its especially fragile zoarium.

The separating thread of the cells is constant but it is very salient and quite visible on the old, strongly calcified zooecia. 
Affinities.-This species resembles very much Petraliella chuakensis Waters, 1913, and we at first identified it so. However, it differs in its much smaller micrometric measurements $(l a=0.25 \mathrm{~mm}$. and not $0.32 \mathrm{~mm}$.), in the presence of two small apertural avicularia, in the occurrence of a thread separating the cells, in the presence of short interareolar costules, and in the much more finely denticulated proximal border of the aperture. It resembles also Petraliella dorsiporosa Busk, 1884, figured by Harmer, 1900, but differs from it in a much larger zooecial avicularium, in the presence of interareolar costules, in the serrate proximal border of the aperture, and in a single cribriform area to each zooecium on the inner face.

Biology.-Our specimens were in reproduction and fixation January 30 and March 19, 1885.

Occurrence.-Albatross Station D. 2366, Gulf of Mexico, off Yuca$\tan ; 22^{\circ} 28^{\prime} 00^{\prime \prime} \mathrm{N}$.; $87^{\circ} 02^{\prime} 00^{\prime \prime} \mathrm{W}$.; $43 \mathrm{~m}$.

Albatross Station D. 2405 , Gulf of Mexico; $28^{\circ} 45^{\prime}$ $00^{\prime \prime} \mathrm{N}$.; $85^{\circ} 02^{\prime} 00^{\prime \prime} \mathrm{W}$.; $30 \mathrm{fms}$.; gray sand, broken coral.

Albatross Station D. 2414, Gulf of Mexico; $25^{\circ} 04^{\prime}$ $30^{\prime \prime} \mathrm{N}$.; $82^{\circ} 59^{\prime} 15^{\prime \prime} \mathrm{W}$.; $26 \mathrm{fms}$; fine white sand, broken shells.

Cotypes.-Cat. No. 7569, U.S.N.M.

\section{Genus COLEOPORA Canu and Bassler, 1927 \\ COLEOPORA GRANULOSA, new species}

Plate 33, Figure 9

Description.-The zoarium is incrusting. The zooecia are large, distinct, separated by a very thin thread, somewhat elongated, swollen; the frontal is convex and formed of a granular tremocyst; the peristomie is salient, free, cylindrical; the peristome is thin. The aperture is suborbicular.

$$
\begin{aligned}
\text { Measurements. - Aperture }\left\{\begin{array}{l}
h a=0.20 \mathrm{~mm} . \\
l a=0.25 \mathrm{~mm} .
\end{array}\right. \\
\text { Zooecia }\left\{\begin{array}{l}
L z=1.15-1.25 \mathrm{~mm} . \\
l z=0.75-0.85 \mathrm{~mm} .
\end{array}\right.
\end{aligned}
$$

Affinities.-The peristome shows distinctly the tremocyst and the subadjacent olocyst; on certain cells the tremocyst overlaps the olocyst and on others the olocyst is visible.

This species approaches very closely Coleopora minutipora Canu and Bassler from the Philippines, but its micrometric dimensions are much smaller and its frontal granules are larger and more apparent. The genus Coleopora is equatorial. It is probable that it is represented in the Gulf of Mexico.

Occurrence.-Pliocene: Minnitimmi Creek, Bocas Island, Almirante Bay, Panama.

Holotype.-Cat. No. 70834, U.S.N.M. 


\section{Family GALEOPSIDAE Jullien, 1903}

\section{Genus GALEOPSIS Jullien, 1903}

The ovicell is hyperstomial. The aperture has two cardelles. The peristomie is enlarged. The spiramen is very large and salient. The frontal is a tremocyst. The operculum bears two lateral bands. Avicularia.

Genotype.-Galeopsis pupa Jullien, 1903.

Range.-Cretaceous (Maastrichtian)-Recent.

Historica?.-The genus Galeopsis was introduced into the nomenclature by Jullien, 1903, for two species with large spiramen-G. rabidus and G. pupa which he had discovered. He recognized that the spiramen was a tube opening in the peristomie above the operculum and he explained its physiologic function. Lacking material, he was not able to elucidate the structure of the new genus. Our definition of 1923 is therefore uncertain. At this time, conforming to the rules of nomenclature, we chose as the genotype the first species cited ( $G$. rabidus). In our materials from the Philippines, we have had the fortune to discover some new species of Galeopsidae and to make a detailed study of them. We can now explain the structure of these animals and give better generic definitions.

First our selected genotype (G. rabidus) from its structure belongs in reality to Gigantopora, Ridley, 1881. To preserve the name the second species (G. pupa) should be regarded as the type of the genus Galeopsis. In consequence we here revise our definition of 1920.

Affinities.-As now limited the genus Galeopsis is very close to Gephyrophora Busk, 1884, and Waters, 1908, did not hesitate to unite them. The opercula, not being perfectly identical, we believe the two genera should be maintained at least provisionally. Galeopsis differs from Gephyphora in the presence of cardelles, in the absence of a sinus to the aperture, and in the presence of two lateral bands to the operculum, indicating a different muscular system.

The determination of fossil specimens is very difficult and it can be done only by dissection of the peristomie. The recent species are as follows, showing it is an equatorial genus solely:

Galeopsis pupa Jullien, 1903, Pacific (Philippines, Gambier).

Galeopsis mutabilis Canu and Bassler ms., Philippines.

Galeopsis brevicapitata Canu and Bassler ms., China Sea.

\section{Genus STENOPSIS Canu and Bassler, 1927}

The ovicell is hyperstomial. The aperture is rounded-quadrangular, without cardelles. The peristomie is elongated. The spiramen is broad and salient. The frontal is a tuberose tremocyst. The operculum is thin, semielliptical, and without muscular attachments. Avicularia.

Genotype.-Stenopsis (Porina) fenestrata Smitt, 1873. 
Range.-Eocene (Jacksonian)-Recent.

The known species are as follows:

Stenopsis (Porina) fenestrata Smitt, 1873, Gulf of Mexico.

Stenopsis unirostris Canu and Bassler ms., Sulu Sea.

Stenopsis cylindrica, new name (=Gigantopora fenestrata Waters 1908), Red Sea.

Stenopsis (Galeopsis) longicollis Canu and Bassler, 1920, Jacksonian. Stenopsis (Galeopsis) cyclops Canu and Bassler, 1920, Jacksonian. Stenopsis (Porina) tuberculosa Maplestone, 1902, Miocene.

This is an equatorial genus. The ovicell opens into the peristomie. Affinities.-Stenopsis differs from Galeopsis Jullien, 1903, in the absence of cardelles and in its opercula without bands or points. It differs from Gigantopora Ridley, 1881, which it resembles in general aspect, in the presence of a granular tremocyst. It differs from Gephyrophora Busk, 1884, in its longer peristomie and in the absence of rimule and points to the operculum.

STENOPSIS FENESTRATA Smitt, 1873

Plate 14, Figures 9, 10; text Figure 11d

1873. Hippothoa fenestrata Sмıтт, Floridan Bryozoa. Kongl. Svenska Vetenskaps-Akademiens, Handlingar, vol. 11, p. 47, pl. 6, fig. 112.

(Not Gigantopora fenestrata Waters, 1908.)

$$
\begin{gathered}
\text { Measurements.-Aperture }\left\{\begin{array}{l}
h a=0.10 \mathrm{~mm} . \\
l a=0.12 \mathrm{~mm} .
\end{array}\right. \\
\text { Spiramen }\left\{\begin{array}{l}
h=0.10 \mathrm{~mm} . \\
l=0.12 \mathrm{~mm} .
\end{array}\right. \\
\text { Zooecia }\left\{\begin{array}{l}
L z=0.90-1.00 \mathrm{~mm} . \\
l z=0.35-0.40 \mathrm{~mm} .
\end{array}\right.
\end{gathered}
$$

Structure.-The aperture is semielliptical; its exact form is aptly defined as "rounded-quadrangular" by Smitt; it is visible at the bottom of the peristomie, which must be broken in order to render it clearly visible. The operculum has the same form and its proximal border is slightly concave; it bears neither muscular attachments nor ornaments; it is thin and fragile.

The peristome is thin, orbicular, very long, not covered by the tremocyst. It bears laterally a single triangular, thin avicularium, with the beak above.

The spiramen is placed at the base of the peristomie; it is salient and in the form of a lunar crescent with a distal concavity; its dimensions are exactly those of the aperture. The ovicell is globular and opens into the peristomie.

Affinities.-Waters, 1908, determined under this name a different species from the Red Sea and for which we have proposed the name of S. cylindrica because of its zooecial aspect. Stenopsis fenestrata differs from it in its long peristomie, in the great distance between 
the spiramen and the peristomice, in the presence of frontal granulations and a single avicularium, in its greater micrometric dimensions, and in its crescentic spiramen. It is much larger than Stenopsis unirostris Canu and Bassler which we have discovered in the Philippines. Our specimens creep over serpulae and nullipores. They were in reproduction in March, 1885.

Occurrence.-Albatross Station D. 2405, Gulf of Mexico; $28^{\circ} 45^{\prime}$ $00^{\prime \prime} \mathrm{N}$.; $85^{\circ} 02^{\prime} 00^{\prime \prime} \mathrm{W}$.; 30 fms.; gray sand, broken coral.

Plesiotypes.-Cat. No. 7599, U.S.N.M.

\section{Family SCLERODOMIDAE Levinsen, 1909}

\section{Genus SEMIHASWELLIA Canu and Bassler, 1917}

SEMIHASWELLIA SINUOSA, new species

\section{Plate 15, Figures 1-4}

Description.-The zoarium is articulated, the segments are long (10 mm.), subcylindrical, sinuous, with the zooecia on one face only; the anterior face bears tremopores arranged at the bottom of longitudinal, irregular, shallow sulci, and small, round, widely spaced avicularia. The zooecia are little distinct, much elongated; the frontal is convex and formed of a tremocyst with tubules the orifices of which are arranged at the bottom of longitudinal shallow sulci. The ascopore is small, round, placed on the median axis and at the base of the peristomie; the latter is somewhat salient and terminated by a fringed and orbicular peristome. The ovicell is globular, arranged laterally and opening into the peristomie. The base of articulation (basis ramae) is formed by a frontolateral eminence pierced by a large central pore surrounded by smaller pores; the flexible fibers are issued not only from the central pore but also from the small neighboring tremopores.

$$
\text { Measurements.-Zooecia }\left\{\begin{array}{c}
L z=0.50 \mathrm{~mm} \text {.; diameter of peristome, } \\
0.12 \mathrm{~mm} . \\
l z=0.25 \mathrm{~mm} \text {.; diameter of segments, } \\
0.50 \mathrm{~mm} .
\end{array}\right.
$$

Structure.-In longitudinal section the zooecial walls are very thick; the tubules are very wide, although their orifice is very small, the ascopore is wide somewhat oblique, opening in the interior into the peristomie at the level of the operculum.

The ovicell is very remarkable and unique; instead of being arranged distally as in the genotype, it is placed laterally between the peristome and the ascopore. We have not, unfortunately, enough specimens to make a section of the ovicell and verify if it is a dissymetric peristomial ovicell or an ordinary hyperstomial ovicell. Affinities.-The genotype Semihaswellia proboscidea Waters, 1889, has been dredged at a great depth around St. Thomas (West Indies). The presence of other species of the same genus in the Gulf of Mexico 
is then quite natural. We note, in fact, no essential difference between the two species. However, Semihaswellia sinuosa differs from $H$. proboscidea in its articulated zoarium (and not branched) and in its lateral, not distal ovicell.

Among the fossils from the Jacksonian we have found a smaller species, Semihaswellia exilis Canu and Bassler, 1920, in which we have been able to explain the structure. The anologies with the present species are evident and permit us to deduce from it that the large hollow apophysis is in reality a base of articulation and that the colony was articulated as a base of the figured segment proves. (Fig. 22, pl. 66.)

As all these species are quite rare and their study is quite incomplete, the task of the paleontologist is very difficult. Semihaswellia proboscidea Waters, 1889, has been found in the pteropod ooze at 729 meters of depth.

Occurrence.-Albatross Station D. 2392, Gulf of Mexico; $28^{\circ} 47^{\prime}$ $30^{\prime \prime} \mathrm{N}$.; $87^{\circ} 27^{\prime} 00^{\prime \prime} \mathrm{W}$.; 724 fms.; brown gray mud.

Cotypes.-Cat. No. 7591 , U.S.N.M.

\section{Genus TESSARADOMA Norman, 1868}

TESSARADOMA GRACILE Sars, 1863

Plate 15, Figure 5; Plate 28, Figure 6

1873. Tessaradoma boreale SмIт, Floridan Bryozoa. Kongl. Svenska Vetenskaps-Akademiens Handlingar, vol. 11, p. 32, pl. 6, figs 143-145.

1903. Tessaradoma gracile Jullien, Bryozoaires de l'Hirondelle. Resultats des Campagnes scientifiques du Prince de Monaca, p. 74, pl. 3, fig. 4, and pl. 14, fig. 2. (Bibliography,)

1907. Tessaradoma borealis CALvet, Bryozoaires. Expedition Scientifique Travailleur et Talisman, p. 405.

1912. Tessaradoma gracile NORDGAARD, Revision av universitetsmusets samling av norske Bryozoer. Kgl. norske Videnskaber Selskabs, Skriften, p. 20.

1918. Tessaradoma gracile NordgaArd, Bryozoa from the Arctic region. Tromso Museums Aarshefter, vol. 40, p. 53 (numerous localities cited, temperature).

It is difficult to recognize the true micrometric characteristics of this species. The measurements taken from the figures of the authors are extraordinarily divergent as may be noted from the following examples:

\begin{tabular}{|c|c|c|c|c|c|c|c|}
\hline & \multirow{2}{*}{$\begin{array}{c}\text { Canu col- } \\
\text { lection } \\
\text { (North } \\
\text { Atlantic) }\end{array}$} & \multirow{2}{*}{ Smitt, 1867} & \multirow{2}{*}{$\begin{array}{c}\text { Smitt, } \\
1873\end{array}$} & \multicolumn{2}{|c|}{ Hincks, 1880} & \multirow{2}{*}{$\begin{array}{l}\text { Jullien, } \\
1903\end{array}$} & \multirow{2}{*}{ D. 2117} \\
\hline & & & & Fig. 5 & Fig. 4 & & \\
\hline $\begin{array}{l}\text { Diameter of peristome } \\
\text { Length } \\
\text { Width }\end{array}$ & $\begin{array}{c}\text { Milli- } \\
\text { meters } \\
0.16 \\
.90 \\
.60\end{array}$ & $\begin{array}{r}\text { Milli- } \\
\text { meters } \\
0.18-0.20 \\
1.20 \\
.60\end{array}$ & $\begin{array}{c}\text { Milli- } \\
\text { meters } \\
0.18 \\
1.28 \\
.60\end{array}$ & $\begin{array}{c}\text { Milli- } \\
\text { meters } \\
0.14 \\
.70 \\
.33\end{array}$ & $\begin{array}{c}\text { Milli- } \\
\text { meters } \\
0.10 \\
.40 \\
.24\end{array}$ & $\begin{array}{c}\text { Milli- } \\
\text { meters } \\
0.10 \\
.40 \\
.22\end{array}$ & $\begin{array}{c}\text { Milli- } \\
\text { meters } \\
0.25 \\
1.50-1.60 \\
.75-.90\end{array}$ \\
\hline
\end{tabular}


The measurements observed on our specimens are the largest. They appear to constitute a variety. In their ornamentation they approach especially the figures of Smitt, 1873, and of Jullien, 1903. Smitt states that the species is very common in the Gulf of Mexico.

Occurrence.-Albatross Station D. 2117, Caribbean Sea; $15^{\circ} 24^{\prime}$ $40^{\prime \prime} \mathrm{N}$.; $63^{\circ} 31^{\prime} 30^{\prime \prime} \mathrm{W}$.; $683 \mathrm{fms}$.; yellow mud, fine sand; D. 2753 , Lesser Antilles.

Geographic distribution.-Atlantic: From Spitzberg to Cape Verde Islands from 300 to 3,700 meters.

Plesiotypes.-Cat. No. 7605, U.S.N.M.

Family ESCHARELLIDAE Levinsen, 1909

\section{Subfamily Schizoporellae Canu and Bassler, 1917}

\section{Genus BUFFONELLARIA Canu and Bassler, 1927}

The ovicell is hyperstomial and not closed by the operculum. The frontal is an olocyst with vein-like markings. There is a small oral avicularium.

Genotype.-Hippothoa divergens typica Smitt, 1873. Recent.

This genus differs from Buffonella Jullien, 1888, only in the movement of the operculum which closes the ovicell. We know three equatorial species of this genus-Buffonellaria divergens Smitt, 1872; $B$. reticulata, new species, from the Gulf of Mexico; and $B$. loculifera Canu and Bassler from the Philippines.

Relations between the oral avicularia and the function of the operculum in the Escharellidae are shown by the fact that when there is no oral avicularium present the operculum closes the ovicell, and when there is an oral avicularium the operculum does not close the ovicell. This is not a special phenomenon in Buffonellaria for it is general in all the Escharellidae Buffonella, Lacerna, Dakaria, Schizomavella, Hippsponella, and Houzeauina do not have oral avicularia and their operculum closes the ovicell. On the contrary, Buffonellaria, Gemelliporella, Schizopodrella, Hippomenella, Hippozeugosella, Peristomella, and Romancheina have two oral avicularia and their operculum does not close their ovicell. We have incomplete data on other genera of the family, especially when they are fossil; finally, certain of them such as Hippoporina are perhaps poorly classified.

In the uncertain family, Galeopsidae the same phenomenon is observable; Haswellia has no avicularia and its operculum closes the ovicell. On the contrary Galeopsis and Gephyrophora provided with avicularia do not have their operculum closing the ovicell. Very probably the genera of this family should be united to the Escharellidae. 
In the Smittinidae and the Reteporidae, the operculum does not close the ovicell and there are no oral avicularia present, but in these two families there are oral glands.

We have always supposed that the zooecial avicularia have a physiologic function when they are constant. This new study completely confirms this supposition. But we do not yet know exactly how this function is exercised and if it is always the same.

We may again note how fruitful the physiologic classification is and how great are the results obtained by its use. Thanks to it, these small animals have already revealed many secrets of their complicated biology.

\section{BUFFO NELLARIA DIVERGENS Smitt, 1873}

Plate 8, Figures 7, 8; text Figure $13 a$

1873. Hippothoa divergens typica Smitw, Floridan Bryozoa. Kongl. Svenska Vetenskaps-Akademiens Handlingar, vol. 11 , no. 4, p. 47, pl. 9, fig. 179.

Measurements._Aperture $\left\{\begin{array}{l}h a=0.09 \mathrm{~mm} . \\ l a=0.10-0.12 \mathrm{~mm} .\end{array}\right.$

$$
\text { Zooecia }\left\{\begin{array}{l}
L z=0.65 \mathrm{~mm} . \\
l z=0.45-0.55 \mathrm{~mm} .
\end{array}\right.
$$

Structure.-The ovicell is very fragile, placed on the distal zooecium, and opened very widely above the operculum and without any rela-

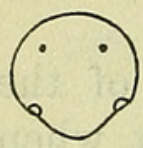

A

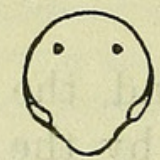

B

Fig. 13.-Opercula of BUfFonellARIA. A. B. DIVERGENS SMITT, 1873 . B. B. RETiculata, NEW SPECIES tionship with it. It is smooth and convex. The operculum is suborbicular with two lucidae at the place of the condyles of articulation; the two muscular attachments are removed from the margin and placed rather high.

The frontal, seen by transparency, shows the radial threads characteristic of Buffonellaria. This structure is very different from that of Hippothoa and can not be confused with it. There is generally only a small oral avicularium.

Affinities.-It is in error that Hincks, 1880, Norman, 1909, and Osburn, 1914, have referred this species to Stephanosella biaperta Michelin, 1848. Not only it has not the same form of operculum, but the structure of the ovicell is very different; finally, the frontal is an olocyst with nerve-like threads and not a tremocyst with small pores. We have not found specimens corresponding to Smitt's Figure 177 (forma laxa).

Biology.-Our specimens encrust Cellepores, hydroids, and corals. They were in reproduction in May, 1884, and January, 1885. This species has been found only in deep waters. 
Occurrence.-Albatross Station D. 2167 , off Habana, Cuba; $23^{\circ} 10^{\prime}$ $40^{\prime \prime}$ N.; $82^{\circ} 20^{\prime} 30^{\prime \prime}$ W.; 201 fms.; coral.

Albatross Station D. 2320 , north of Cuba; $23^{\circ} 10^{\prime}$ $39^{\prime \prime}$ N.; $82^{\circ} 19^{\prime} 48^{\prime \prime}$ W.; 130 fms.; fine coral.

Florida, 218 meters (Smitt).

Plesiotypes.-Cat. No. 7459, U.S.N.M.

\section{BUFFONELLARIA RETICULATA, new species}

Plate 8, Figure 4, text Figure $13 b$

Description.-The zoarium encrusts nullipores and shells. The zooecia are indistinct; the frontal bears salient reticulations which divide it into small irregular compartments. The aperture is buried at the bottom of an infundibuliform peristomie; its proximal border bears a rounded and deep sinus; the peristome is very salient, thin, nodular, and bears a kind of small avicularium. The ovicell is globular and decorated with two orbicular areas symmetrically arranged; it is hyperstomial and is not closed by the operculum.

Measurements.-Apertura $\left\{\begin{array}{l}h a=0.14 \mathrm{~mm} . \\ l a=0.12 \mathrm{~mm} .\end{array}\right.$

$$
\text { Zooecia }\left\{\begin{array}{l}
L_{z}=0.40-0.50 \mathrm{~mm} \\
l_{z}=0.30 \mathrm{~mm}
\end{array}\right.
$$

Structure.-This is a bizarre species the structure of which has for a time appeared enigmatic; we have finally concluded that the frontal reticulations result from the thickening of the olocystal veins characteristic of Buffonellaria; the young zooecia are deprived of them. The small oral avicularium is rather constant; it appears elliptic, but on our dried specimens we have not observed the direction of its mandible.

The operculum is similar to that of Buffonellaria divergens and bears also two lucidae corresponding to the two condyles of articulation. The dimensions are rather variable.

The exterior aspect of the aperture is deceiving, for it is not in rapport with the true form of the operculum, the rimule of the latter being much wider than the proximal sinus of the aperture.

The ovicell bears a system of nervelike threads like the frontal, but they are less salient and the principal ones limit the two perforated lateral areas.

Biology.-Our living specimens were in reproduction March 15, 1885. Several of them encrust both sides of shell fragments. This is a rather frequent phenomenon that is difficult to explain otherwise than by the floating of the substratum.

Occurrence.-Albatross Station D. 2405, Gulf of Mexico; $28^{\circ} 45^{\prime}$ $00^{\prime \prime} \mathrm{N}$.; $85^{\circ} 02^{\prime} 00^{\prime \prime} \mathrm{W}$; $30 \mathrm{fms}$.; gray sand, broken coral.

Holotype.-Cat. No. 7460 , U.S.N.M. 


\section{Genus GEMELLIPORELLA Canu and Bassler, 1920}

The ovicell is hyperstomial and not closed by the operculum. The frontal is an olocyst bordered by areolar pores and covered by a granular pleurocyst. There are oral avicularia.

Genotype.-Gemelliporella vorax Canu and Bassler, 1923.

Range.-Miocene-Recent.

Gemelliporella asper and G. vorax Canu and Bassler, 1923, belong to this genus. In 1923 we were deceived by the aspect of the aperture of the fossil specimens, but an examination of the recent specimens enables us to correct this false interpretation.

\section{GEMELEIPORELLA ASPER Canu and Bassler 1923}

Plate 10, Figure 1

1923. Gemelliporella asper CANU and BASsLer, North American Later Tertiary and Quaternary Bryozoa. Bull. 125, U. S. National Museum, p. 110 , pl. 18 , figs. 5,6 .

Measurements.-Aperture $\left\{\begin{array}{l}h a=0.12-0.15 \mathrm{~mm} . \\ l a=0.08-0.10 \mathrm{~mm} .\end{array}\right.$

$$
\text { Zooecia }\left\{\begin{array}{l}
L z=0.50 \mathrm{~mm} . \\
l_{z}=0.40-0.45 \mathrm{~mm} .
\end{array}\right.
$$

Structure.-Like the frontal, the ovicell is formed by an olocyst surmounted by a pleurocyst, but the latter is incomplete and leaves in front a small semicircular cicatrix. The small oral avicularium is elliptical and little salient; the large zooecial avicularium is arranged laterally; it is salient and its mandible is wide and horny; the pivot bears a very characteristic distal tooth. The areolar pores are large and scattered from each other.

Our recent specimens are somewhat less calcified than the fossils. Their large avicularium is much smaller than that in specimens from the Miocene but it is equal to that of the Pliocene examples.

Biology. - The great development of the avicularia seems to indicate rather calm waters. Our recent specimens encrust nullipores; the fossils encrusted oysters.

Occurrence.-Albatross Station D. 2322 , north of Cuba; $23^{\circ} 10^{\prime}$ $54^{\prime \prime}$ N.; $82^{\circ} 17^{\prime} 45^{\prime \prime}$ W.; 115 fms.; coral.

Geologic distribution.-Miocene and Pliocene of Florida and South Carolina.

Plesiotype.-Cat. No. 7533, U.S.N.M.

\section{Genus STYLOPOMA Levinsen, 1909}

Levinsen, 1909, published his doubt as to the validity of this genus and even suppressed it. According to his ideas, the passage of the eggs is a function which each species operates differently and 
according to circumstances. We have always thought that this is an important function which is of generic importance. We violate this principle sometimes, but it is only in genera in which the species are rare and in order not to change the nomenclature uselessly. This is not the case in the genus Stylopoma, in which we already know the following seven species.

Stylopoma spongites Pallas, 1766, Miocene-Recent.

Stylopoma minuta Canu and Bassler, 1923, Miocene (Jamaica).

Stylopoma magniporosa Canu and Bassler, 1923, Miocene (Santo Domingo).

Stylopoma projecta Canu and Bassler, 1923, Pleistocene (Panama). Stylopoma distorta, new species, Recent (Philippines).

Stylopoma parviporosa, new species, Recent (Philippines).

Stylopoma grandis, new species, Recent (Philippines).

This is an equatorial genus but it has been observed in the larger oceans such as the Atlantic, Indian, and Pacific. We have not yet found it in the Southern Hemisphere.

\section{STYLOPOMA SPONGITES Pallas, 1766}

Plate 10, Figures 8-10; Plate 32, Figure 9, text Figure 14

1918. Schizoporella spongites Waters, Bryozoa of the Cape Verde Islands. Journal Linnean Society, Zoology, vol. 34, p. 16, pl. 2, figs. 10-13.

1923. Stylopoma spongites $\mathrm{CANU}_{\mathrm{AN}}$ and BAssler, North American Later, Tertiary and Quaternary Bryozoa. Bull. 125, U. S. National Museum, p. 102, pl. 17, figs. 1-12. (Bibliography, geographic distribution.) Measurements.-Aperture $\left\{\begin{array}{l}h a=0.10 \mathrm{~mm} \text {. (without sinus). } \\ l a=0.12-0.15 \mathrm{~mm} .\end{array}\right.$

$$
\text { Zooecia }\left\{\begin{array}{l}
L z=0.50 \mathrm{~mm} . \\
l_{z}=0.35 \mathrm{~mm} . \text { (variable). }
\end{array}\right.
$$

Variations.-Smitt in 1873, Waters in 1918, and ourselves in 1923 have indicated the great zooecial variations of this species. The colonial variations are also numerous; the zoaria can be observed in spongy masses, often very large, in multilamellar hemescharian colonies, in uni or multilamellar encrusting surfaces, and in unilamellar cylindrical forms. Furthermore, in the waters off Florida we have observed magnificent bilamellar dendroid colonies of free or anastomosing, very regular, compressed fronds. This is a very capricious animal which can adapt itself to all the biologic conditions possible; but this faculty of adaptation is always accompanied by correlative variations.

Structure.-On the interior the tremopores are very small and at a magnification of 20 diameters they are visible only by transparency. There are no condyles to the aperture. The operculum is very thin and quite fragile; the proximal rimule is subtriangular and it is much 
wider than the apertural sinus which is thin and linear. The form appears quite variable, for that which we figure is a little different from the opercula figured by Levinson, 1909, and by Waters, 1918.

We have never observed the apertural denticles described by Waters, 1918. We believe that his specimen from Manaar is of another species.

Biology.-The larva scarcely chooses its substratum for it is affixed to shells, bryozoa, corals, sponges, rocks, and fronds of small algae. However, we have not yet observed colonies on nullipores. "The color varies from translucent white or yellow to bright brick red" (Osburn).

This is a very fecund species, the frequency of specimens and the abundance of ovicells being the immediate manifestations. This fecundity has increased in time, for the ovicells of the fossil specimens. are generally smaller than the ovicells of the recent specimens.
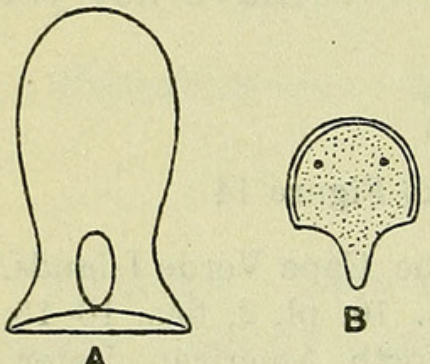

A

Fig 14.-STYLOPOMA SPONGITES PALIA S, $1766 . A$. MANDIBLE OF AN INTERZOOECIAL AVICULARIUM. $B$. OPERCULUM

Reproduction was observed during the first. three months of the year.

An ordinary polypide constructs the zooecium. It degenerates and is replaced by a female polypide which constructs the ovicell above the distal zooecium and the aperture. It is deprived of tentacles which could not emerge through the special orifice of the ovicell. The passage of the eggs is thus assured in an absolute fashion. The escape of the larvae operates as in other species by the rupture of the membrane which closes the ovicell.

Occurrence.-Albatross Station D. 2319, north of Cuba; $23^{\circ} 10^{\prime} 37^{\prime \prime}$ N.; $82^{\circ} 20^{\prime} 06^{\prime \prime}$ W.; $143 \mathrm{fms}$.; gray coral. Albatross Station D. 2320, north of Cuba; $23^{\circ} 10^{\prime} 39^{\prime \prime}$ $\mathrm{N}$.; $82^{\circ} 18^{\prime} 48^{\prime \prime} \mathrm{W}$.; $130 \mathrm{fms}$.; fine coral. Albatross Station D. 2405, Gulf of Mexico ; $28^{\circ} 45^{\prime} 00^{\prime \prime}$ $\mathrm{N}$.; $85^{\circ} 02^{\prime} 00^{\prime \prime} \mathrm{W}$.; 30 fms.; gray sand, broken coral.

Florida, 21-56 meters (Smitt); Tortugas, 5-29 meters (Osburn).

Pliocene: Minnitimmi Creek, Bocas Island, Almirante Bay, Panama.

Caribbean Sea, St. Thomas and St. John (Levinsen); Bermuda (Verrill); Cape Verde Islands, 16 meters (Waters), and perhaps Ceylon (Thornely) and Malacca (Levinsen).

Geologic distribution.-Upper Miocene of Virginia to Florida; Pliocene of Florida; Pleistocene of South Carolina, Florida, and Panama.

Plesiotypes.-Cat. Nos. 7600, 70861, U.S.N.M. 


\section{Genus SCHIZOPODRELLA Canu and Bassler, 1917}

SCHIZOPODRELLA INCRASSATA, new species

Plate 9, Figures 1-4

?1923. Gemelliporella vorax $\mathrm{CANU}$ and BAsSLER part, North American Later Tertiary and Quaternary Bryozoa. Bull. 125, U. S. National Museum, p. 111, pl. 19, fig. 1.

Description.-The zoarium encrusts algae, or more often develops into bilamellar fronds, dichotomous and compressed laterally. The young zooecia only are distinct, elongated, convex, all the others are indistinct with thick frontal and with irregularly arranged avicularia; the frontal is formed by an olocyst perforated by very small pores surmounted by a very thick tremocyst with large scattered pores. The ovicell of the young zooecia is globular and of the other zooecia is little visible, not salient, embedded in the calcified wall of the tremocyst; it is finely porous. Two small avicularia are arranged symmetrically on each side of the apertural sinus; a large zooecial avicularium, orbicular and salient, is distributed irregularly on the old zooecia.

$$
\begin{array}{r}
\text { Measurements.-Aperture }\left\{\begin{array}{l}
h a=0.10 \mathrm{~mm} . \\
l a=0.06-0.08 \mathrm{~mm} .
\end{array}\right. \\
\text { Young zooecia }\left\{\begin{array}{l}
L z=0.40 \mathrm{~mm} . \\
l z=0.30 \mathrm{~mm} .
\end{array}\right.
\end{array}
$$

Structure,-This species is very difficult to study because of its irregularity and its structure is visible only on preparations. Even on the young zooecia the tremopores are not apparent. They appear, on the contrary, very clearly on the interior especially on preparations examined by transparency. The muscular attachments of the operculum are placed far from the edge and toward the superior part.

It is probable that Figure 1, on plate 19 of our 1923 work, which we have considered as a variety of Gemelliporella vorax, really belongs to the present species. Our specimens were in reproduction March 19,1885 .

Occurrence.-Albatross Station D. 2405, Gulf of Mexico; $28^{\circ} 45^{\prime}$ $00^{\prime \prime} \mathrm{N}$.; $85^{\circ} 02^{\prime} 00^{\prime \prime} \mathrm{W}$.; $30 \mathrm{fms}$.; gray sand, broken coral (bilamellar).

Albatross Station D. 2639, Straits of Florida; $25^{\circ} 04^{\prime}$ $50^{\prime \prime} \mathrm{N}$.; $80^{\circ} 15^{\prime} 10^{\prime \prime} \mathrm{W}$.; 56 fms.; coral sand (unilamellar). ? Pliocene of South Carolina.

Holotype.-Cat. No. 7585, U.S.N.M.

\section{SCHIZOPODRELLA FLORIDANA Osburn, 1914}

Plate 10, Figures 4-6; text Figure $15 d, e$

1914. Schizoporella floridana OsBurn, Bryozoa of the Tortugas Islands, Florida. Publication Carnegie Institution, Washington, no. 182, p. 205, figs. 17, 18. 
1923. Schizopodrella floridana $\mathrm{C}_{\mathrm{ANU}}$ and Bassler, North American Later Tertiary and Quaternary Bryozoa. Bull. 125, U. S. National Museum, p. 106, pl. 16, figs. 11-15.

Measurements.-Aperture $\left\{\begin{array}{l}h a=0.17-0.20 \mathrm{~mm} . \\ l a=0.15 \mathrm{~mm} .\end{array}\right.$

$$
\text { Zooecia }\left\{\begin{array}{l}
L z=0.85-90 \mathrm{~mm} . \\
l z=\text { variable. }
\end{array}\right.
$$

Structure.-In 1923 we figured a group of marginal zooecia oriented and deprived of the large frontal avicularium. The other zooecia are arranged in every way; they bear an enormous, very salient avicularium which has furnished us the mandible. This lack of orientation explains the irregularities of our section of 1923; it approaches, however, that Waters figured, 1918, for Schizoporella viridis and in which the arrangement indicated the independence of the superposed lamellae in the multilamellar colonies.
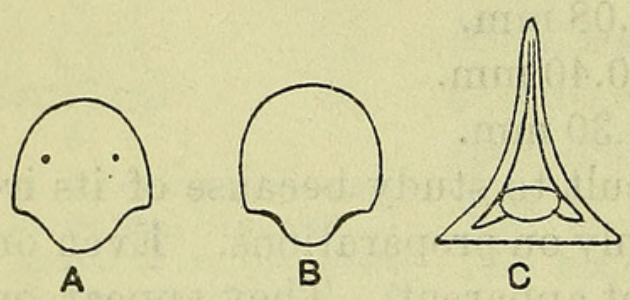

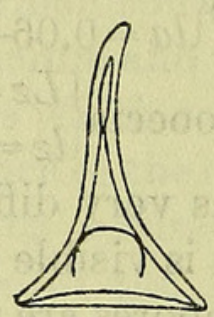

E

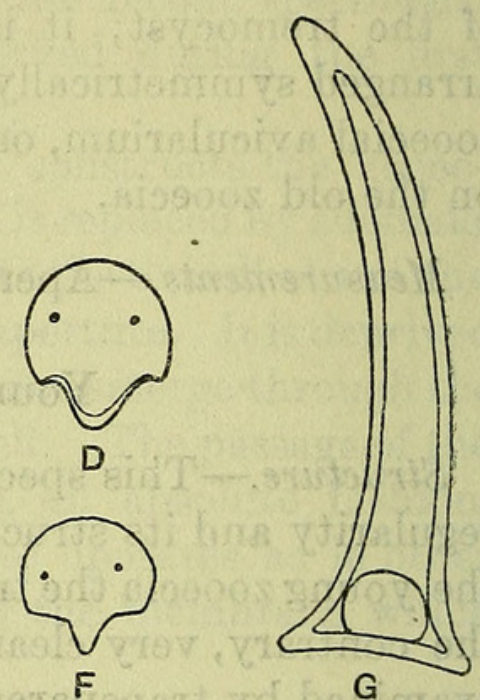

G

Fig. 15.-Genus Schizopodrella Canu and Bassler, 1917. A-C. Schizopodrella pungens, New Species. $A, B$. TWo opercula, $\times 85$. C. MANDible, $\times 85 . \quad D, E$. SCHizopodrella Floridana Osburn, 1914. D. Operculum. E. Mandible of a large avicularium. $F$, $G$. Schizopodrella FALCifERA, NEW SPECIES. $F$. OPERCULUM. $G$. MANDible of large interzooecial avicularium

The operculum is light colored. It has no peculiarities of form. On the interior the tremopores are not visible at an enlargement of $\times 20$, but they are apparent by transparency; there are no condyles for the articulation of the operculum.

Biology.-The colonies form voluminous masses attaining the size of the fist, according to the number of superposed lamellae. The latter curve around and surround a small stony fragment; sometimes the substratum is an algal frond and it is necessary that the colony be very light in spite of its large volume. "The color ranges from pure white to dark purplish and red" (Osburn). The frontal ectocyst is alone colored; the interior of the zooecia as well as all the calcareous skeleton is not colored.

Only the young marginal zooecia have the aspect shown in Osburn's figure. The other cells are unoriented, the oral avicularium is lack- 
ing or is much reduced and the large frontal avicularium is often wanting.

Our living specimens were in reproduction January 30, 1884.

Occurrence.-Albatross Station D. 2363, east of Yucatan; $22^{\circ} 07^{\prime}$ $30^{\prime \prime} \mathrm{N}$.; $87^{\circ} 06^{\prime} 00^{\prime \prime} \mathrm{W}$.; $21 \mathrm{fms}$; ; white coral rock.

Geologic distribution.-Miocene of North Carolina and Florida.

Plesiotypes.-Cat. No. 7582, U.S.N.M.

\section{SCHIZOPODRELLA FALCIFERA, new species}

Plate 10, Figures 2, 3; text Figure $15 f, g$

Description.-The zoarium encrusts Cellepores. The zooecia are distinct, separated by a shallow furrow, rectangular; the frontal is a tremocyst with small pores and is little convex. The aperture is placed eccentrically, rarely in the zooecial median axis. It is suborbicular with a rather deep proximal, triangular sinus. A small avicularium is placed at the side of the aperture; it is very thin and elongated. On the zoarial surface appears sporadically a large, very elongated somewhat falciform avicularium placed on a salient eminence.

$$
\begin{gathered}
\text { Measurements.-Aperture }\left\{\begin{array}{l}
h a=0.15 \mathrm{~mm} . \\
l a=0.15 \mathrm{~mm} .
\end{array}\right. \\
\text { Zooecia }\left\{\begin{array}{l}
L z=0.45-0.50 \mathrm{~mm} . \\
l z=0.30-0.35 \mathrm{~mm} .
\end{array}\right.
\end{gathered}
$$

Affinities.-The operculum is of the Schizopodrella type; the two muscular attachments are removed from the border.

This species resembles Schizopodrella longirostris Hincks, 1886, in the often eccentric position of its aperture but differs from it in the very different form of its zoarial avicularium which covers two or three zooecia. Our specimen was in reproduction January 30, 1905.

Occurrence.-Albatross Station D. 2365, east of Yucatan; $22^{\circ} 18^{\prime}$ $00^{\prime \prime} \mathrm{N}$.; $87^{\circ} 04^{\prime} 00^{\prime \prime} \mathrm{W}$.; $24 \mathrm{fms}$.; white rock coral.

Holotype-Cat. No. 7583, U.S.N.M.

SCHIZOPODRELLA PUNGENS, new species

Plate 27, Figures 5-12; text Figure $15 a-c$

Description.-The zoarium encrusts shells or soft algae at their bifurcation. It is uni or multi lamellar. The zooecia are distinct, separated by a deep furrow, elongated, elliptical; the frontal is convex and formed by a granular tremocyst with large pores. It is ornamented with a more or less salient umbo placed on the median axis in the vicinity of the apertura. The apertura is somewhat elongated; the anter is large and semicircular; the poster is small, distinct, with a broad rounded rimule; the peristome is thin, salient, furnished with very short spines. The oral avicularium is thin, triangular, with very salient beak; it is placed obliquely, adjacent to 
the poster and on one side only. The ovicell is large globular, porous, covering a large portion of the distal zooecium.

$$
\begin{gathered}
\text { Measurements.-Apertura }\left\{\begin{array}{l}
h a=0.14-0.15 \mathrm{~mm} . \\
l a=0.12 \mathrm{~mm} .
\end{array}\right. \\
\text { Zooecia }\left\{\begin{array}{l}
L z=0.60-0.75 \mathrm{~mm} . \\
l z=0.30-0.40 \mathrm{~mm} .
\end{array}\right.
\end{gathered}
$$

Variations.-The colonies have generally the aspect of hollow tubes of a half centimeter in diameter, irregularly ramified, and of a length measuring as much as 3 centimeters. These tubes are never ancestrular. One of these colonies still had its base fixed on a small shell and then developed, forming an arborescent ensemble. Although living, as no trace of the alga was observed at the center of the tubes, we suppose that the latter was very fragile and naturally was destroyed during cleaning of the specimens.

The avicularia are the most variable organs. Their beak is very salient and at times perpendicular to the apertural plane. On certain zooecia they are placed exactly on the frontal. They are generally oriented obliquely toward the top of the colony, but this orientation varies considerably according to the irregularity of the substratum and of the budding; rarely the point is oriented toward the base. Their length varies from one branch to another $(0.20 \mathrm{~mm}$. to $0.30 \mathrm{~mm})$. Whatever the orientation or size may be, the mandible is always lowered on the rimule.

The zooecia of the external lamella are very often irregularly oriented. The size of the frontal mucro is equally variable.

Affinities.-This new species differs from Schizopodrella isabelleana Smitt, 1873, in its elongated and nontransverse aperture, in the presence of a frontal mucro, and in its larger avicularia.

The projections on the zoarial surface made by the umbo and by the avicularia give it a prickly aspect which enables the species to be rather easily distinguished.

On specimens boiled in Javelle water the aperture shows the same features as in Schizopodrella isabelleana; on each side of the rimule there are two very small secondary indentations.

Biology.-The avicularia are not zooecial but they are indeed oral avicularia not only because their occurrence is constant but also because the mandible in opening comes always in immediate contact with the rimule. Their function remains mysterious but it appears in connection with the hydrostatic system.

The larva fixes itself on dead shells which the colony surrounds in developing their many lamellae. If the shell is small the ensemble must be very light and buoyant. But the colonies develop with much more ease on shells already covered with algae or with radicles. They encrust the latter, forming the curious tubes described pre- 
viously. These tubes are frequently separated from the primitive shell and form floating masses.

Occurrence.-Gulf of Mexico, Cedar Keys, Florida. Albatross Station D. 2362, east of Yucatan; $22^{\circ} 8^{\prime} 30^{\prime \prime} \mathrm{N}$.; $86^{\circ} 53^{\prime} 30^{\prime \prime}$ W.; 25 fms.; coral sand.

Cotypes.-Cat. No. 7586, U.S.N.M.

SCHIZOPODRELLA ISABELLEANA Smitt, 1873

Plate 27, Figures 1-4

1873. Hippothoa isabelleana Smitr, Floridan Bryozoa. Kongl. Svenska Vetenskaps-Akademiens Handlingar, vol. 10, p. 44, pl. 8, figs. 166-168 (not D’Orbigny, 1835).

Measurements.-Aperture $\left\{\begin{array}{l}h a=0.10-0.12 \mathrm{~mm} \\ l a=0.13-0.14 \mathrm{~mm} .\end{array}\right.$ Zooecia $\left\{\begin{array}{l}L z=0.50-0.60 \mathrm{~mm} . \\ l_{z}=0.30-0.45 \mathrm{~mm} .\end{array}\right.$

Structure.-The colonies are multilamellar; they encrust algae at their bifurcation and have the aspect of irregularly ramified hollow tubes. The transverse section is not at all that of the Cellepores and Figure 167 of Smitt is perfectly exact.

The zooecia are rhomboidal or irregular; they are not always well oriented. The ectocyst is rather thick but the tremopores are quite visible by transparency.

The details of the aperture are quite visible, especially on specimens boiled in Javelle water, and they are identical with those of Schizopodrella pungens. The poster bears two very small indentations placed symmetrically on each side of the rimule. This character does not exist in the other species of the genus. The aperture is always somewhat transverse.

The ovicell is porous like the frontal and is never closed by the operculum; it is quite globular, placed on the distal zooecium, which it covers about half.

On the inferior face of the zoarial lamellae the zooecia have a structure analogous to that which Barroso in 1918 and 1921 observed on Schizopodrella unicornis Johnston, 1847. The proximal border of each cell is ornamented with four to six very long denticles quite visible by transparency on our figure. Barroso, 1918, figured them viewed from the interior, and he remarks:

En el angulo que forman la pared de la base y la parte inferior de las zoecias existen uno surcos, siete de ordinario, separados par pequeñas costillas que están como reforzando la union de los dos paredes; no puede apieciarse claramente en los citados surcos perforación, locual las daria significacion de poros de communicación interzoeciales. ${ }^{9}$

- Barroso, Bol. real Sociedad Espanola de Historia Natural, vol. 18, p. 409 (Sep. 2) (1918). $58513-28-7$ 
Affinities.-The determination of this species is not always easy, for it may be confused with two other species of the same general aspect and with analogous dimensions. It differs from Stylopoma spongites Pallas, 1766, in the nature of its ovicell which does not hide the aperture, and in its much larger apertural rimule. It differs from Schizopodrella pungens, new species, in the absence of an umbo on the frontal and in its transverse and nonelongated aperture. It is not Escharina isabelleana D'Orbigny, 1839 , in which the avicularium is placed at the side of the anter and in which the affinities according to Waters, 1906, are rather with Schizopodrella unicornis Johnston, 1847.

Biology.-Our colonies were bluish; this is perhaps what Smitt wished to express in writing that his were of purplish blue tint. They were ovicelled, but as we have not seen the ancestrula it is probable that this was not the month of the escape of the larva and of the fixation.

The avicularia have generally a very salient beak oriented obliquely toward the superior part of the zooecia. Their presence is constant. They are often adjacent to the poster, never the anter. We think that they are oral and that their presence is to supply some internal function of which we are unfortunately ignorant. In the other species of this genus the avicularia are frequently two in number, symmetrically placed on each side of the aperture; it would be convenient then to place Schizopodrella pungens and S. isabelleana in a special section.

The colonies fixed on algae belong to the category of floating bryozoa. They have not necessarily lived at the place where they were dredged and they do not therefore furnish exact bathymetric data.

Occurrence.-St. Thomas, Virgin Islands, West Indies; Florida, 27 meters (?) (Smitt).

Pliocene: Minnitimmi Creek, Bocas Island, Almirante Bay, northwest Panama.

Plesiotypes.-Cat. No. 7584, U.S.N.M.

\section{Genus GEMELLIPORA Smitt, 1873 (part)}

GEMELILPORA GLABRA Smitt, 1873

Plate 12, Figures 1-7; text Figure 16

1885. Gemellipora glabra Busk, Bryozoa of the Challenger. Report Scientific Results Voyage Challenger, vol. 10, p. 176, pl. 25, fig. 3.

1873. Gemellipora glabra Sмiтt, Floridan Bryozoa. Kongl. Svenska Veten skaps Akademiens, Handlingar, vol. 11, p. 37, pl. 11, figs. 207-210

Measurements.-Aperture $\left\{\begin{array}{l}h a=0.18 \mathrm{~mm} \\ l a=0.12 \mathrm{~mm} .\end{array}\right.$

Zooecia $\left\{\begin{array}{l}L z=1.1 \mathrm{~mm} . \\ 7 z=0.5 \mathrm{~mm} .\end{array}\right.$ 
Structure.-The zoarium is formed of dichotomous, cylindrical branches borne by a slightly expanded discoidal base. It is entirely covered over by a thin ectocyst, allowing all the tuberosities and the tremopores of the skeleton to be visible. The latter are small and numerous. The zooecia are indistinct except at the extremity of the branches. The ovicell is salient, globular, almost entirely covered by tremopores; a median cicatrix permits the inferior olocyst to be seen.

In longitudinal section the zoarial walls are very thick and perforated by very numerous tubular tremopores. The transverse section shows six zooecia; the peristome is ornamented by two longitudinal lines of granules.

The operculum is large, oval, with the two small lateral denticles characteristic of the genus; its decoration is rather variable.

Affinities.-The zoarium of Gemellipora punctata Canu and Bassler, 1923, is identical but the present species differs from it in its smaller and more scattered apertures.

Biology.-Our specimens were in reproduc-

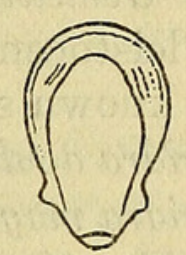

A

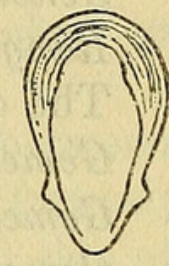

B

Fig. 16.-GEMELLIPORA GLABRA SMITT, 1873. $A, B$. TWO ASPECTS OF THE OPERCULUM, $\times 85$ tion. It is an equatorial species and from shallow water.

Occurrence.-Albatross Station D. 2405, Gulf of Mexico; $28^{\circ} 45^{\prime}$ $00^{\prime \prime} \mathrm{N}$.; $85^{\circ} 02^{\prime} 00^{\prime \prime} \mathrm{W}$.; $30 \mathrm{fms}$.; gray sand, broken coral.

Albatross Station D. 2639, Straits of Florida; $25^{\circ} 04^{\prime}$ $50^{\prime \prime} \mathrm{N}$.; $80^{\circ} 15^{\prime} 10^{\prime \prime} \mathrm{W}$.; $56 \mathrm{fms}$; coral sand.

Fowey Light, 15 miles south of Miami, Fla.; $40 \mathrm{fms}$. Florida, 90 ineters (Smitt). Atlantic: Bahia, 16-48 meters; John Adams Bank (Busk).

Plesiotypes.-Cat. No. 7501, 7502, U.S.N.M.

\section{GEMELLIPORA (?) LIMBATA Smitt, 1873}

1873. Gemellipora limbata Smitr, Floridan Bryozoa. Kongl. Svenska Vetenskaps-Akademiens Handlingar, vol. 11, p. 40, pl. 11, figs. 212-214.

We have found some zooecia of this remarkable monoserial species. They were dead and we have not been able to make a close study of them. We have preserved Smitt's generic name, although the species appears to us to belong to the genus Lagenipora.

The diameter of the apertura is $0.09 \mathrm{~mm}$. The frontal is smooth or areolated.

Biology.-The zoarium encrusts Cellepores (Smitt), shells, or nullipores. It is a species of great depths.

Occurrence.-Albatross Station D. $2152,21 / 2$ miles northwest of Habana Light; 387 fms.; coral.

Albatross Station D. 2320 , north of Cuba; $23^{\circ} 10^{\circ}$ $39^{\prime \prime} \mathrm{N}$.; $82^{\circ} 18^{\prime} 48^{\prime \prime} \mathrm{W}$.; $130 \mathrm{fms}$.; fine coral. Florida, 763 meters (Smitt). 


\section{Genus GEMELLIPORIDRA Canu and Bassler, 1927}

The ovicell is hyperstomial and is always closed by the operculum. The frontal and the ovicell are covered by tremopores. The aperture bears two small lateral indentations separating a very large suborbicular anter from a very small concave poster. The operculum bears two lateral marks corresponding to oral indentations and two linear muscular attachments. There are two oral avicularia irregularly arranged on each side of the aperture. The complete colonies are multilamellar, and the zooecia are then badly oriented.

Genotype.-Gemelliporidra typica Canu and Bassler, 1927. Recent. Range.-Pleistocene. Recent.

The other known species are:

Gemelliporidra aculeata, new species, Recent, Gulf of Mexico.

Gemelliporidra magniporosa, new species, Recent, Gulf of Mexico.

Gemelliporidra (Cyclicopora) multilamellosa Canu and Bassler, 1923, Pleistocene, Panama Canal Zone.

This genus is very close to Gemellipora Smitt, 1873 , in the form of the operculum and of the aperture in which the lateral indentations serve for the insertion of two corresponding denticles on the operculum. It differs in a wider, rounded poster and in its larger, rectangular zooecia poorly oriented (celleporine structure of Smitt).

As in Hippodiplosella, there are two linear bands on the operculum. Gemelliporidra differs from this genus in the absence of cardelles, in the presence of two indentations in the aperture, in two lateral denticles on the operculum, and in the muscular attachments much less clear and more irregular. The genus is known only in the Tropical Zone of the Atlantic.

GEMELLIPORIDRA TYPICA Canu and Bassler, 1927

Plate 11, Figures 1-4, text Figures $17 a-c$

1927. Gemelliporidra typica CANU and BASSLER, Classification Cheilostomatous Bryozoa. Proc. U. S. Nat. Mus., vol. 69, p. 7, pl. 1, fig. 9.

Description.-The zoarium is uni or multi lamellar. The zooecia are large, rectangular, distinct, separated by a salient thread, oriented in all directions, little elongated; the frontal is convex, formed of a perforated olocyst surmounted by a granular tremocyst in which the lateral pores are much larger. The aperture is suborbicular and provided with two lateral indentations separating a very large anter from a concave and sinuous poster. The ovicell is globular and disposed between the olocyst and the tremocyst of the distal zooecium. On each side of the aperture there is a triangular avicularium with pivot, obliquely arranged, with the beak adjacent to the peristome and directed towards the median zooecial axis. 
Measurements.-Aperture $\left\{\begin{array}{l}h a=0.22 \mathrm{~mm} \\ l a=0.19 \mathrm{~mm} .\end{array}\right.$

$$
\text { Zooecia }\left\{\begin{array}{l}
L z=1.10 \mathrm{~mm} . \\
l_{z}=0.90 \mathrm{~mm}
\end{array}\right.
$$

Structure.-The width of the aperture varies from 0.15 to $0.28 \mathrm{~mm}$. The form is orbicular, a little elongated or transverse. On the transverse aperture two very small lateral indentations are visible as in Gemellipora, but it is an exterior aspect occasioned by the presence of two small cardelles. Moreover, this form is not constant and the corresponding opercula are of two kinds-one is regular, the other has a small lateral constriction. The opercular muscles are attached to two lateral bands very close to the border.

The ovicell is buried on the distal zooecium and developed between its olocyst and its tremocyst; it is of the same structure as the frontal; it is relatively small and closed by the operculum. On each side of the aperture there is a transverse thread jointed to the salient thread separating the zooecia. These threads do not limit the zooecia distally, although the aperture appears in a terminal projection; in the interior the aperture is removed from the distal border.
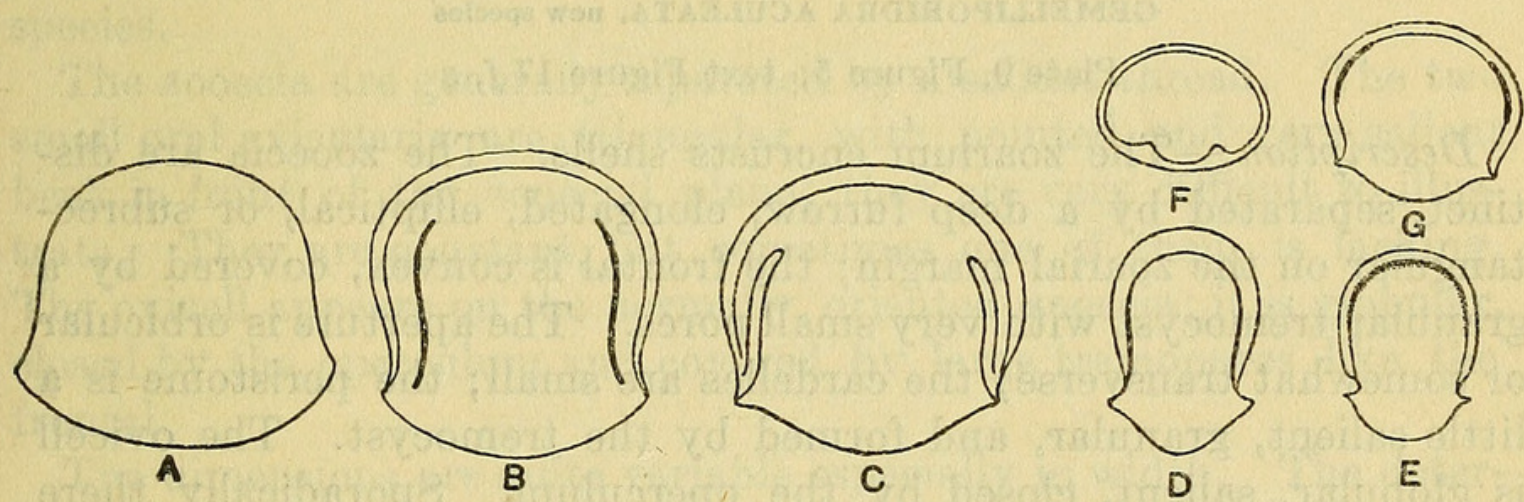

Fig. 17.-Opercula of Gemelliporidra Canu and Bassler, 1927. A-C. Gemelliporidra typica Canu and Bassler, 1927. Ordinary, elongate and transverse opercula, $\times$ 85. $D, E$. Gemelliporidra Magniporosa, New species. Two opercula showing variation, $\times 85$. $F$. $G$. GeMELLIPORIDRA ACULEATA, NEW SPECIES. F. RARE FORM OF OPERCULUM. $G$. ORDiNARY OPERCULUM WITH THE THICK PART OF INNER LINE INDICATING THE INSERTION OF THE OPERCULAR MUSCLES

The frontal is a granular tremocyst; the lateral tremopores are large, the others are very small.

As in all the multilamellar species, the orientation of the zooecia is not constant; sporadically inverted zooecia develop and disarrange the primitive orientation.

The avicularium is placed laterally in the vicinity of the aperture. It is long, triangular, acuminated, provided with a pivot; its beak is directed toward the top and toward the median axis of the zooecium. As it is not constant, its function is only accessory; it does not replace an essential organ of the zooecium itself. In spite of its position, we consider it as a zoarial avicularium of oxygenation. On 
several of our specimens it changes its position and becomes transverse.

The micrometric measurements are quite inconstant and vary from single to double, but the general structure remains always the same. The transverse section indicates that the zooecia of the superposed lamellae arranged in rows and not in quincunx.

Biology.-This species forms large, free colonies, but the lamellae are superposed only on one side. It is incrusted by small species of bryozoa. It appears to prefer the great depths. The dredgings of the Albatross showed it to have been in reproduction from January to May.

- Occurrence.-Albatross Station D. 2167 , off Havana, Cuba; $23^{\circ} 10^{\prime}$ $40^{\prime \prime} \mathrm{N}$; $82^{\circ} 20^{\prime} 30^{\prime \prime} \mathrm{W}$.; $201 \mathrm{fms}$; c coral.

Albatross Station D. 2319 , north of Cuba; $23^{\circ} 10^{\prime}$

$37^{\prime \prime} \mathrm{N}$.; $82^{\circ} 20^{\prime} 06^{\prime \prime} \mathrm{W} ; 143 \mathrm{fms}$.; gray coral.

Albatross Station D. 2330 , north of Cuba; $23^{\circ} 10^{\prime}$

$48^{\prime \prime} \mathrm{N}$.; $82^{\circ} 19^{\prime} 15^{\prime \prime} \mathrm{W} ; 121 \mathrm{fms}$.; gray coral.

Pleistocene: Panama Canal Zone.

Cotypes.-Cat. Nos. 7505, 7506, U.S.N.M.

GEMELLIPORIDRA ACULEATA, new species

Plate 9, Figure 5; text Figure $17 \mathrm{f}, g$

Description.-The zoarium encrusts shells. The zooecia are distinct, separated by a deep furrow, elongated, elliptical, or subrectangular on the zoarial margin; the frontal is convex, covered by a granular tremocyst with very small pores. The aperture is orbicular or somewhat transverse; the cardelles are small; the peristome is a little salient, granular, and formed by the tremocyst. The ovicell is globular, salient, closed by the operculum. Sporadically there are avicularian zooeciules bearing a long slender mandible in the form of a needle; they are always primoserial.

$$
\begin{array}{r}
\text { Measurements.--Aperture }\left\{\begin{array}{l}
h a=0.12-0.15 \mathrm{~mm} . \\
l a=0.15 \mathrm{~mm} .
\end{array}\right. \\
\text { Zooecia }\left\{\begin{array}{l}
L z=0.65 \mathrm{~mm} . \\
l_{z}=0.40 \mathrm{~mm} .
\end{array}\right. \\
\text { Zooeciules }\left\{\begin{array}{l}
L z=0.55 \mathrm{~mm} . \\
l_{z}=0.25 \mathrm{~mm} .
\end{array}\right.
\end{array}
$$

Affinities.-This species is very well characterized by its avicularian zooeciules which are always primoserial. We have found two kinds of opercula; the more transverse belong apparently to the ovicelled zooecia; the others are surrounded by a marginal band on which the opercular muscles are laterally inserted. Our two specimens were dredged alive.

Occurrence.-Fowey Light, 15 miles south of Miami, Fla.; $40 \mathrm{fms}$. Holotype.-Cat. No. 7507, U.S.N.M. 
GEMELLIPORIDRA MAGNIPOROSA Canu and Bassler, 1923

Plate 11, Figures 5-11, text Figure $17 d, e$

1923. Schizoporella magniporosa CANU and Bassler, North American Later Tertiary and Quaternary Bryozoa. Bull. 125, U. S. National Museum, p. 95, pl. 45, figs. 1, 2.

Measurements.-Aperture $\left\{\begin{array}{l}h a=0.16 \mathrm{~mm} . \\ l a=0.12 \mathrm{~mm} .\end{array}\right.$

$$
\text { Zooecia }\left\{\begin{array}{l}
L z=0.60 \mathrm{~mm} . \\
l z=0.40 \mathrm{~mm} . \text { (variable). }
\end{array}\right.
$$

Structure.-We discovered this species in the Pleistocene of Panama, but on the fossil specimens we were unable to discern the true nature of the aperture; the operculum is that of a Gemellipora but somewhat attenuated and less oval; the ornament on it is variable.

The zooecia are not always regularly oriented. Inverse zooecia are formed sporadically and completely disarrange the regularity of the budding. We have observed this phenomenon in many genera but we are ignorant of its cause. For species with celleporine structure Smitt, 1867, created the genus Herentia, but this name has not been admitted into nomenclature because of great diversity of the species.

The zooecia are generally separated by a salient thread. The two small oral avicularia are triangular, with pointed and very salient beak in front of the zooecial plane; they are very difficult to illustrate. They are constant, but sometimes one of them is lacking. The ovicell appears on the normally oriented zooecia; it is globular, closed by the operculum and covered by large tremopores like the frontal.

The dimensions are quite variable especially in width. The determination of isolated specimens is quite difficult.

Biology. - The colonies encrust bryozoa, shells, or grains of sand joined together. Many lamellae are often superposed. The formation of inversed zooecia is, morever, absolutely connected with the plurilamellar phase, for we have observed it in other species of very different genera. The architecture of the bryozoa is so complicated that it often escaped our comprehension.

Our specimens were in reproduction from January to April.

Occurrence.-Albatross Station D. 2157, Gulf of Mexico, off Habana; $23^{\circ} 10^{\prime} 04^{\prime \prime}$ N.; $82^{\circ} 21^{\prime} 07^{\prime \prime}$ W.; 29 fms. Albatross Station D. 2169, off Habana, Cuba; $23^{\circ} 10^{\prime}$ $28^{\prime \prime}$ N.; $82^{\circ} 20^{\prime} 27^{\prime \prime}$ W.; 78 fms.; coral.

Albatross Station D. 2362 , east of Yucatan; $22^{\circ} 08^{\prime}$ $30^{\prime \prime} \mathrm{N}$.; $86^{\circ} 53^{\circ} 30^{\prime \prime} \mathrm{W}$.; 25 fms.; coral sand.

Pleistocene of Panama (Canu and Bassler).

Plesiotypes.-Cat. Nos. 7503, 7504, U.S.N.M. 


\section{GEMELLIPORIDRA MULTILAMELLOSA Canu and Bassler, 1923}

1923. Cyclicopora multilamellosa CANU and Bassler, North American Later Tertiary and Quaternary Bryozoa. Bull. 125, U. S. National Museum; p. 138, pl. 46, figs. 3-6.

This interesting fossil species is sornewhat smaller than Gemelliporiära typica and differs still more in its small and transverse aperture and in its much longer avicularia, with the beak always oriented toward the base of the zooecium.

We were unable to establish the true structure of this species on the fossil specimens previously studied, but the discovery of three recent species now permits us to incorporate it in the genus Gemelliporidra.

Occurrence.-Pleistocene: Mount Hope, Panama Canal Zone.

Pliocene: Minnitimmi Creek, Bocas Island, Almirante Bay, Panama.

\section{Subfamily HippoporaE Canu and Bassler, 1917}

\section{Genus HIPPOPORINA Neviani, 1895}

HIPPOPORINA CLEIDOSTOMA Smitt, 1873

Plate 9, Figure 7; Plate 32, Figure 5; text Figure 18

1873. Lepralia cleidostoma Smiтt, Floridan Bryozoa. Kongl. Svenska Vetenskaps-Akademiens Handlinger, vol. 11, p. 62, pl. 11, figs. 217-219. Not Waters, 1899, Norman, 190 .

Measurements. - Aperture $\left\{\begin{array}{l}h a=0.14 \mathrm{~mm} \text {. } \\ l_{a}=0.10 \mathrm{~mm} .\end{array}\right.$

$$
\text { Zooecia }\left\{\begin{array}{l}
L_{z}=0.40-0.50 \mathrm{~mm} \\
l_{z}=0.24-0.30 \mathrm{~mm}
\end{array}\right.
$$

Affinities.-This species is not at all Hippoporina porcellana, Busk, 1860, found at Madeira and studied successfully by Waters, 1899,

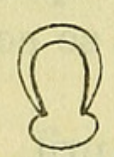

A

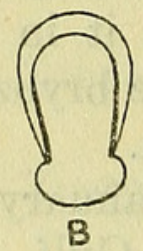

B

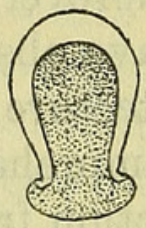

C
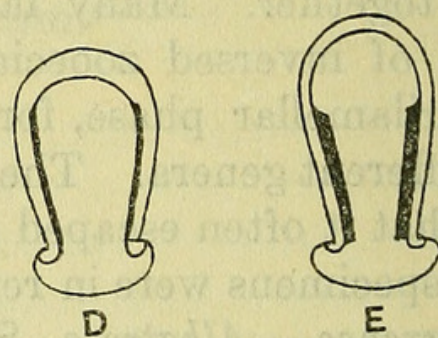

E

Fig. 18.-Hippoporina cleidostoma Smitt, 1873. A- $E$. Different Forms of the OPERCULUM WHICH IS MUCH CHITINIZED

and Norman, 1909. It differs from it in its more elongated zooecia, in its larger and more elongated operculum, and in its aperture much less removed from the distal border of the cell. This error of synonymy obliges us to revise our text Figure 114 of 1920 .

The zooecia are very small in the vicinity of the ancestrula and increase regularly up to the border of the colony. The aperture is 
subject to the same phenomenon so that opercula of all the sizes can be found. We have figured some of them. In comparing them with those of Waters, 1899, it is easy to note that they have neither the same proportions nor the same size and that they belong to a perfectly distinct species. The zoarial avicularium is rather rare; we have, however, observed it twice on the ancestrula. The operculum does not close the ovicell.

Biology.-The colonies are rarely unilamellar and free; they generally encrust shells, Cellepores, corals, and hydroids; three specimens were plurilamellar; but this celleporoid structure is very rare. "The color of the colony is shining white, either pure or with a bluish tinge" (Smitt). Our living specimens were in reproduction in May-April, 1885. This is one of the more common species of the Gulf of Mexico. It will be easy to dredge living specimens to study the larva, which appears to us poorly classed in the Escharellidae and its great bathymetric range should correspond to a larger geologic distribution. Kirkpatrick believed he had discovered it in China, but he did not figure his specimens. The species discovered in Japan by Ortmann, 1890, and in Queen Charlotte Island by Hincks, 1884, appear to approach more Hippoporina porcellana Busk, 1860.

Occurrence.-Albatross Station D. 2167, off Habana, Cuba; $23^{\circ} 10^{\prime}$ $40^{\prime \prime} \mathrm{N}$.; $82^{\circ} 20^{\prime} 30^{\prime \prime} \mathrm{W}$.; $201 \mathrm{fms}$; coral.

Albatross Station D. 2365, east of Yucatan; $22^{\circ} 18^{\prime}$ $00^{\prime \prime} \mathrm{N}$.; $87^{\circ} 04^{\prime} 00^{\prime \prime} \mathrm{W}$.; 24 fms.; white rock coral. Albatross Station D. 2405, Gulf of Mexico; $28^{\circ} 45^{\prime}$ $00^{\prime \prime} \mathrm{N}$.; $85^{\circ} 02^{\prime} 00^{\prime \prime} \mathrm{W}$.; $30 \mathrm{fms}$; ; gray sand, broken coral.

Albatross Station D. 2639, Straits of Flordia; $25^{\circ} 04^{\prime}$ $50^{\prime \prime}$ N.; $70^{\circ} 53^{\prime} 00^{\prime \prime}$ W.; 133 fms.; green sand.

Plesiotypes.-Cat. Nos. 7517, 7518, U.S.N.M.

Fowey Light, 15 miles south of Miami, Fla.; $40 \mathrm{fms}$. Florida, 48-194 meters (Smitt).

Pliocene: Minnitimmi Creek, Bocas Island, Almirante Bay, Panama.

\section{Genus HIPPADENELLA Canu and Bassler, 1917}

HIPPADENELLA FLORIDANA, new species

Plate 9, Figure 8; text Figure $19 a$

Description.-The zoarium creeps over chitinous sponges. The zooecia are distinct, separated by a deep furrow, elongated, elliptical, more or less broad; the frontal is very convex, bordered by areolar pores, covered with a pleurocyst; the avicularian chamber is small, convex, little salient, median. The aperture is suborbicular, two short and broad cardelles separating a large anter from a small poster, 
with proximal concave border; the peristome is very thin and very little salient. The ovicell is large, globular, placed on the distal zooecium.

Measurements.-Aperture $\left\{\begin{array}{l}h a=0.18 \mathrm{~mm} . \\ l a=0.18 \mathrm{~mm} .\end{array}\right.$

$$
\text { Zooecia }\left\{\begin{array}{l}
L z=0.90-1.00 \mathrm{~mm} . \\
l_{z}=0.35-0.50 \mathrm{~mm} .
\end{array}\right.
$$

Structure.-Two specimens only have been found, the smaller of
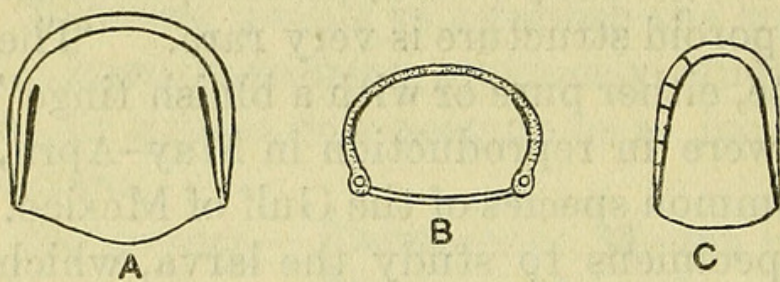

Fig. 19.-Opercula, $\times$ 85. A. Hippadenella FloriDANA, NEW SPECIES. $B$. HIPPODIPLOSIA PERTUSA ESPER, 1894. THE THICKENED PORTION OF THE INNER LINE INDICATES THE PLACE OF THE OPERCULAR MUSCles. C. HIPPOMENELLA RUBRA, NEW SPECIES

which was destroyed in the preparation of the operculum. The latter is wide suborbicular; the proximal border is slightly sinous, the muscular attachments are long and very little removed from the border. This is the typical operculum of the Hippoporae. On our dry specimen we have not been able to verify exactly if the operculum closes the ovicell. The ectocyst is very thin.

Occurrence.-Cedar Keys, Fla.

Holotype.-Cat. No. 7525, U.S.N.M.

\section{Genus HIPPODIPLOSIA Canu, 1916}

\section{HIPPO DIPLOSIA PERTUSA Esper, 1794}

Plate 9, Figure 6; Plate 32, Figure 10; text Figure $19 b$

1873. Escharella pertusa Smiтt, Floridan Bryozoa. Kongl. Svenska Vetenskaps-Akademiens Handlingar, vol. 11, p. 55.

1880. Lepralia pertusa HıNcks, British Marine Polyzoa, p. 305, pl. 43, figs. $4,5$.

1881. Lepralia periusa JuLlien, List des Bryozoaires à Etretat. Bulletin Société Zoologique de France, vol. 5, p. 11.

1896. Hippoporina pertusa Neviani, Corellarii e Briozoi neogenici di sardegna. Bolletina della Societá, geologica Italiana, vol. 15, p. 15.

1896. Lepralia pertusa Hennig, Bryozoer fran Westgrönland. Kongl. Vetenskaps-Akademiens Forhandlingar, vol. 53, p. 358.

1902. Lepralia pertusa Calvet, Bryozoaires marins des côtes de Corse. Travaux Institut de Zoologie Université Montpellier, ser. 2, mem. No. 12 , p. 26.

1902. Lepralia periusa Calvet, Bryozoaires marins de la region de Cette. Travaux Institut Zoologie Université Montpellier, ser. 2, mem. No. 11, p. 51.

1903. Lepralia pertusa Jullien and Calvet, Bryozoaires provenant des campagnes del' Hirondelle. Resultats du Campagnes Scientifiques du Prince de Monaco, fasc. 23, p. 69, fig. 134.

1905. Eschara nordlandica NORDgAARD, Hydrographical and biological investigations in Norwegian fiords, p. 167, pl. 4, fig. 32-35 (fide Nordgaard). 
1906. Eschara nordlandica NordaAaRd, Bryozoa from the second Fram Expedition, 1898-1902. Report second Norwegian Expedition Fram, p. 22.

1912. Lepralia pertusa OsBurn, Bryozoa of the Woods Hole Region. Bull. Bureau of Fisheries, vol. 30, p. 241, pl. 26, fig. 56 .

1918. Hippoporina pertusa NoRdgaARD, Bryozoa from the Arctic regions. Tromso Museums Aarshefter, vol. 40, p. 59.

1919. Hipporina pertusa OsBuRn, Bryozoa of the Crocker Land Expedition. Bulletin American Museum Natural History, vol. 16, p. 611.

$$
\begin{array}{r}
\text { Measurements.-Aperture }\left\{\begin{array}{l}
h a=0.14-0.18 \mathrm{~mm} . \\
l_{a}=0.18-0.20 \mathrm{~mm} .
\end{array}\right. \\
\text { Zooecia }\left\{\begin{array}{l}
L_{z}=0.60-0.70 \mathrm{~mm} \\
l_{z}=0.40-0.50 \mathrm{~mm}
\end{array}\right.
\end{array}
$$

Structure.-The frontal is formed by an olocyst surmounted by a tremocyst with small pores; the latter is incomplete in the vicinity of the aperture so that the subjacent olocyst is visible in the proximal portion of the aperture; the peristome limits the tremocyst and not the aperture and it is more or less expanded.

The ovicell is developed between the olocyst and the pleurocyst of the distal zooecium in which it is embedded. The operculum closes the ovicell; it is semielliptical, transverse. The muscles are attached to a lateral point of an inner peripheral band somewhat thickened on the sides. The operculum does not resemble that which Nordgaard, 1905, illustrated for his Eschara nordlandica. The zooecia are little convex and separated by a salient thread.

Affinities.-The older bibliography of this species is rather confused; for the geographic distribution it is prudent to rely only upon determinations made after the publication of the more exact figures of Hincks, 1880. We do not see any great difference from Flustra mangnevilleana Savigny-Audouin, 1828. According to Smitt, the apertural width of the latter is $0.23 \mathrm{~mm}$. and, according to the published figures, the zooecia are more convex, not separated by a salient thread, and the cardelles are more salient and placed a little higher. We have been able to compare directly our specimens from Habana with those of Le Croisic (France).

Biology. - The species appears to be in reproduction almost all the year. It grows on algae as well as on solid bodies; but it fixes itself very rarely on siliceous pebbles. Ițs bathymetric range is rather large but it prefers the more shallow waters. It is rarely observed below 100 meters; one time on the Newfoundland Banks it was dredged at 155 meters of depth. It characterizes the Temperate Zone and does not extend beyond the Tropic of Cancer or the Polar Circle. Its presence in the Pacific is still doubtful. The determination of the fossils must be revised; however, it appears to begin in the European Miocene. 
Occurrence.-Albatross Station D. 2362 , east of Yucatan; $22^{\circ} 08^{\prime}$ $30^{\prime \prime}$ N.; $86^{\circ} 53^{\prime} 30^{\prime \prime}$ W.; 25 fms.; coral sand.

Florida, 97 meters (Smith).

Pliocene: Minnitimmi Creek, Bocus Island, Almirante Bay, Panama.

Geographic distribution.-Northern Atlantic: Europe from the mouth of the Loire to Spitsberg. America; Florida and Greenland. Mediterranean.

Plesiotype.-Cat. No. 7521, U.S.N.M.

\section{Genus HIPPOMENELLA Canu Bassler, 1917}

HIPPOMENELLA RUBRA, new species

Plate 10, Figure 7; text Figure 19c

Description.-The zoarium is unilamellar and creeps over algae; it is a beautiful glistening red. The zooecia are distinct, separated by a deep fnrrow, elongated, ovoid, swollen; the frontal is convex, ornamented by a double range of areolar pores and by small granules. The aperture is large, elongated, elliptical; the peristome is salient and formed by the tremocyst; it bears six to eight large hollow spines; it is enlarged and expanded in its proximal portion. The ovicell is large, globular, buried in the distal zooecium, closed by the operculum; it is bordered with areolar pores ornamented with costules converging toward a proximal tuberosity. The avicularia are implanted in the vicinity of the peristome; they are long, thin, triangular, tapering; their beak is directed exteriorily and turned toward the base.

$$
\begin{array}{r}
\text { Measurements. - Aperture }\left\{\begin{array}{l}
h a=0.15-0.18 \mathrm{~mm} . \\
l_{z}=0.13-0.15 \mathrm{~mm} .
\end{array}\right. \\
\text { Zooecia }\left\{\begin{array}{l}
L_{z}=0.70-0.75 \mathrm{~mm} . \\
l_{z}=0.60 \mathrm{~mm} .
\end{array}\right.
\end{array}
$$

Affinities.-The ancestrula is very small, its frontal is very short. The ancestrular zooecia are smaller than the marginal zooecia and are deprived of avicularia. The avicularia are inconstant and often absent; we consider them as zoarial.

Hippothoa mucronata Smitt, 1873 , is a species very close, perhaps identical, having the same frontal, same ovicell, the same spines, and the same color. Our species differs from it only in the presence of the avicularia and in the tuberosity of the ovicell placed lower and not in the middle.

This species differs from Lepralia mucronelliformis Waters, 1899, from Madeira in its smaller dimensions, a larger aperture, and two more spines on the peristome.

The discovery of this species in the Gulf of Mexico is important, for it permits the recognition of the true characters of the genus 
Hippomenella abundant in the American Eocene. It is, unfortunately, very rare.

Biology.-Our specimen was dredged living and was in reproduction and fixation March 15, 1885.

Occurrence.-Albatross Station D. 2405, Gulf of Mexico; $28^{\circ} 45^{\prime}$ $00^{\prime \prime} \mathrm{N}$.; $85^{\circ} 02^{\prime} 00^{\prime \prime} \mathrm{W}$.; $30 \mathrm{fms}$.; gray sand, broken coral.

Holotype.-Cat. No. 7516, U.S.N.M.

\section{Genus LEPRALIA Johnston, 1847 \\ LEPRALIA PALLIOLATA, new species}

Plate 12, Figure 11; text Figure 20d

Description.-The zoarium encrusts fragments of shells; the zooecia are distinct, separated by a deep furrow, elongated, elliptical; the frontal is quite convex, smooth, formed of two superposed calcareous lamellae. The aperture is small and formed of a large semicircular anter separated by two cardelles from a wider poster with concave proximal border. The ovicell is hyperstomial, never closed by the operculum, globular, smooth; it is formed by two calcareous lamellae of which the superior one is incomplete and limits a small frontal cicatrix. The ancestrula is very small. There is a small a vicularium in front of the aperture.

$$
\begin{aligned}
& \text { Measurements.-Aperture }\left\{\begin{array}{l}
h a=0.09 \mathrm{~mm} \\
l a=0.08 \mathrm{~mm} .
\end{array}\right. \\
& \text { Zooecia }\left\{\begin{array}{l}
L z=0.50 \mathrm{~mm} \\
l_{z}=0.30 \mathrm{~mm} .
\end{array}\right.
\end{aligned}
$$

Structure.-The structure of this charming specimen is unusual. The aperture as well as the small avicularia perforates the interior lamella of the frontal. The exterior lamella almost entirely covers the frontal without burying the avicularium, bears spines, and forms on the adult zooecia a kind of false peristome at the bot-

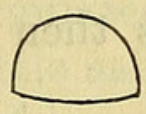

A

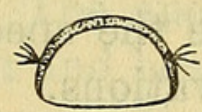

B

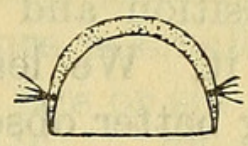

C

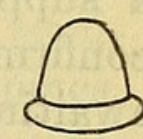

D

Fig. 20.-Opercula of Microporella. A. Microporella ciliata linnaeus, 1758 . $B, C$. Microporella ampla, NEW SPECIES. $D$. LePralia PALliolata, NEW SPECIES。 OPERCULUM, $\times 85$ tom of which the aperture and the avicularium are placed. The zooecium appears thus to be covered with a kind of small mantle. The structure of the ovicell is identical; the exterior lamella is incomplete and forms a small linear frontal cicatrix.

It is very difficult to classify this species. The presence of the oral avicularium and the vanna larger than the porta are characters nonexistent in Hippoporina. Moreover, we are ignorant of the structure of the interior lamella. We have found only three specimens of this species, one of which has served in the preparation of the operculum; we are not able then to continue the study. The operculum is divided into two parts and bears no muscular attachments. 
Occurrence.-Albatross Station D. 2639, Straits of Florida; $25^{\circ} 04^{\prime}$ $50^{\prime \prime} \mathrm{N}$.; $80^{\circ} 15^{\prime} 10^{\prime \prime} \mathrm{W}$.; 56 fms.; coral sand.

Holotype.-Cat. No. 7537, U.S.N.M.

LEPRALIA FISSURATA, new species.

Plate 33, Figure 1

Description.-The zoarium encrusts shells. The zooecia are distinct, separated by a furrow, elongated, elliptical; the frontal is convex, perforated by large tremopores scattered and separated by large salient granulations. The aperture is elliptical, very little elongated; two small cardelles separate a large anter from a much smaller poster; the peristome is thin, nonsalient. The ovicell is large, globular, smooth, buried on the distal zooecium, hyperstomial; it bears a long longitudinal fissure, very irregular in width. One or two small avicularia are arranged in the vicinity of the poster.

Measurements.-Aperture $\left\{\begin{array}{l}h a=0.15 \mathrm{~mm} \\ l a=0.12 \mathrm{~mm} .\end{array}\right.$

$$
\text { Zooecia }\left\{\begin{array}{l}
L z=0.40-0.47 \mathrm{~mm} . \\
l z=0.35-0.40 \mathrm{~mm} .
\end{array}\right.
$$

Affinities.-At first sight this species appears to be a Lepraliella but it differs however in its nondeltoid ovicellarian fissure and often formed by two simple pores united by a fissure. This structure is very remarkable and it is very difficult to interpret it on the fossils.

The ovicell appears to be independent of the cell into which it does not open. Moreover, it is deprived of the usual transverse slit by which the larvae can escape. We can then only admit that the longitudinal fissure serves for this latter function. But this is only a supposition and the examination of recent specimens only can confirm it. We leave the species then in the old genus Lepratia, awaiting better observations.

Occurrence.-Pliocene: Minnitimmi Creek, Bocas Island, Almirante Bay, Northwest Panama.

Holotype.-Cat. No. 70846, U.S.N.M.

Subfamily Microporellae Canu and Bassler, 1917

Genus MICROPORELLA Hincks, 1877

MICROPORELLA CILIATA Linnaeus, 1759

Text Figure $20 a$

1914. Microporella ciliata OsBurn, Bryozoa of the Tortugas Islands. Publieation Carnegie Institution, Washington, No. 182, p. 208. (Regional bibliography.)

1923. Microporella ciliata $\mathrm{C}_{\mathrm{ANU}}$ and BASSLER, North American Later Tertiary and Quaternary Bryozoa. Bull. 125, U. S. National Museum, p. 119, pl. 20, figs. 1-6, pl. 36, figs. 4, 5. (Recent bibliography and geologic distribution.) 
Measurements.-Aperture $\left\{\begin{array}{l}h a=0.08 \mathrm{~mm} . \\ l a=0.10-0.14 \mathrm{~mm} .\end{array}\right.$

$$
\text { Zooecia }\left\{\begin{array}{l}
L z=0.50 \mathrm{~mm} . \\
l z=0.32 \mathrm{~mm} .
\end{array}\right.
$$

The zooecial width frequently attains $0.40 \mathrm{~mm}$. and there are two a vicularia symmetrically arranged.

Biology.-Our specimens encrust nullipores, shells, bryozoa, and corals. They were almost all living and in reproduction or fixation. One time only have we seen the ectocyst slightly pigmented with green.

The period of reproduction appears very long, but we have not yet enough data concerning it. Moreover, this species is quite cosmopolitan and the notes published on it are so numerous that its biology could be learned.

Occurrence.-Fowey Light, 15 miles south of Miami, Fla.; $40 \mathrm{fms}$. Albatross Station D. 2405, Gulf of Mexico; $28^{\circ} 45^{\prime}$ $00^{\prime \prime} \mathrm{N}$.; $85^{\circ} 02^{\prime} 00^{\prime \prime} \mathrm{W}$.; $30 \mathrm{fms}$.; gray sand, broken coral.

Albatross Station D. 2639, Straits of Florida; $25^{\circ} 04^{\prime}$ $50^{\prime \prime} \mathrm{N}$.; $80^{\circ} 15^{\prime} 10^{\prime \prime} \mathrm{W}$.; $56 \mathrm{fms}$.; coral sand.

Tortugas, 8-29 meters (Osburn); Florida, 11-97 meters (Smitt).

\section{MICROPORELLA AMPLA, new species}

Plate 12, Figures 8-10; text Figure 20b, $c$

Description.-The zoarium encrusts nullipores. The zooecia are distinct, separated by a deep furrow, little elongated, hexagonal, very broad and large; the frontal is convex and finely granular; the ascopore is small, round, marginated. The aperture is small, semielliptical; the peristome is little salient and bears five or six spines. The ovicell is small, globular, fringed around the orifice. The avicularia are arranged symmetrically on each side of the aperture; they are small, triangular; their mandible is directed upward and toward the median axis of the distal zooecium.

$$
\begin{array}{r}
\text { Measurements.-Aperture }\left\{\begin{array}{l}
h a=0.10 \mathrm{~mm} . \\
l a=0.12 \mathrm{~mm} .
\end{array}\right. \\
\text { Zooecia }\left\{\begin{array}{l}
L z=0.70-0.74 \mathrm{~mm} . \\
l z=0.50 \mathrm{~mm} .
\end{array}\right.
\end{array}
$$

This species is very well characterized by its large dimensions and its small avicularia. The variations in width on the same colony are extraordinary, as may be noted on our figures. The colony measured 6 square centimeters of surface. It was in reproduction. The operculum is bordered by a thick sclerite.

Occurrence.-Albatross Station D. 2152, $2 \frac{1}{2}$ miles northwest of Habana Light; 387 fms.; coral.

$$
\text { Holotype.-Cat. No. 7557, U.S.N.M. }
$$


MICROPORELLA NORMANI, new name.

Plate 34, Figure 5

1909. Microporella coronata Norman, The Polyzoa of Madeira, Journal Linnean Society Zoology, vol. 30, p. 297, pl. 39, fig. 4.

Measurements.-Aperture $\left\{\begin{array}{l}h a=0.08 \mathrm{~mm} . \\ l a=0.15 \mathrm{~mm} .\end{array}\right.$

$$
\text { Zooecia }\left\{\begin{array}{l}
L z=0.65-0.75 \mathrm{~mm} . \\
l_{z}=0.40-0.55 \mathrm{~mm} .
\end{array}\right.
$$

Affinities.-According to Waters, 1908, Microporella coronata Audouin, 1826, is a smaller species in which the dimensions are, aperture $=0.08$ by $0.12 \mathrm{~mm}$. and zooecia $=0.56$ by $0.36 \mathrm{~mm}$. Norman's figure indicates only the broad cells; our specimens contain a mixture of broad and long cells, but we have not seen other differences.

This species is well characterized by its large avicularia almost adjacent to the aperture. It is very close to Microporella californica Busk, 1856, in the ensemble of its measurements and in its general characters. It differs from it only in the absence of a frontal gibbosity, in its somewhat shorter zooecia, in slightly broader aperture, and in its smaller avicularia.

Waters identified these three species with that of Audouin, 1826. This is possible, for they have very much the same exterior aspect, but we prefer, however, to separate them as the materials for comparison in our possession are not sufficient.

Occurrence.-Recent: Madeira. Pliocene: Minnitimmi Creek, Bocas Island, Almirante Bay, northwest Panama.

Cotypes.-Cat. No. 70849 , U.S.N.M.

\section{Genus FENESTRULINA Jullien, 1888}

\section{FENESTRULINA MALUSI Savigny-Audouin, 1826}

1923. Fenestrulina malusi CANU and Bassler, North American Later Tertiary and Quaternary Bryozoa. Bull. 125, U. S. National Museum, p. 118, pl. 36, figs. 2, 3. (Bibliography, geologic, and geographic distribution.)

In our work of 1923 we wrote: "It is remarkable that this very cosmopolitan species has never been observed in the western Atlantic as fossil as well as recent." Since then we have been fortunate enough to discover two ovicelled specimens living on Stylopoma spongites in the waters of Florida.

Occurrence.-Albatross Station D. 2405 , Gulf of Mexico; $28^{\circ} 45^{\prime}$ $00^{\prime \prime} \mathrm{N}$.; $85^{\circ} 02^{\prime} 00^{\prime \prime} \mathrm{W}$.; 30 fms.; gray sand, broken coral. 
Family TUBUCELLARIIDAE Busk, 1884

Genus TUBUCELLARIA D'Orbigny, 1852

TUBUCELLARIA CEREOIDES Ellis and Solander, 1786

Plate 15, Figure 6; Plate 33, Figure 7

1907. Tubucellaria cereoides Waters, Tubucellaria: its species and ovicells.

Linnean Society's Journal Zoology, vol. 30, p. 129, pl. 15, figs. 8, 9,

15, 16. (Bibliography, geographic and geologic distribution.)

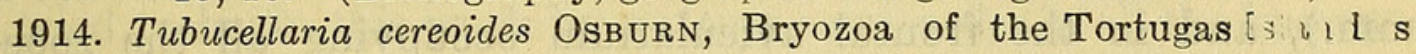

Publication Carnegie Institution, Washington, No. 182, p. 203.

1917. Tubucellaria cereoides $\mathrm{CANU}_{\mathrm{AN}}$, Les Bryozoaires fossiles des terrains du'

Sud-Ouest de la France, XI, Rupelien. Bulletin Société geologique

France (7 ser. 4), vol. 17, p. 357 (characteristics).

This very cosmopolitan species has not yet been discovered in the western Atlantic on the American shores. Osburn, 1914, discovered one segment at Tortugas. We have been fortunate to discover three segments at Fowey Light. We give a photograph of one of them in order to show that we are not deceived in our determination.

The bushy zoaria of Tubucellaria cereoides are often attached to algae and the depth at which the segments are found is not of very great bathymetric value.

Occurrence.-Fowey Light, 15 miles south of Miami, Fla.; $40 \mathrm{fms}$. Tortugas, 24 meters (Osburn).

Pliocene: Minnitimmi Creek, Bocas Island, Almirante Bay, Panama.

Plesiotypes.-Cat. No. 7607, U.S.N.M.

\section{Family SMITTINIDAE Levinsen, 1909}

\section{Genus CYSTISELLA Canu and Bassler, 1917}

CYSTISELLA AMERICANA, new species

Plate 15, Figures 7,8

Description.-The zoarium is free and bilamellar. The zooecia are distinct, separated by a deep furrow, elongated, subcylidrical; the frontal is quite convex, smooth, entirely covered by the frontal avicularium which bears a large triangular callosity. The aperture is semicircular. The ovicell is globular, very fragile. The orifice of the avicularium is placed on the proximal border of the aperture and in a plane perpendicular to it.

$$
\begin{gathered}
\text { Measurements. - Aperture }\left\{\begin{array}{l}
h a=0.10 \mathrm{~mm} . \\
l a=0.12 \mathrm{~mm} .
\end{array}\right. \\
\text { Zooecia }\left\{\begin{array}{l}
L z=0.80 \mathrm{~mm} . \\
l z=0.30-0.35 \mathrm{~mm} .
\end{array}\right.
\end{gathered}
$$


The known recent species of the genus Cystisella are northern. The discovery of a fossil species in the Midwayan of Alabama with a subtropical fauna causes us to anticipate a much larger geographic distribution. We have been fortunate to discover the figured specimen in the Gulf of Mexico near New Orleans.

This new species differs from C. saccata Busk, 1856, in its smaller apertural dimensions, in the absence of two proximal pores in the avicularium cavity, in the shorter zooecium $(0.80 \mathrm{~mm}$. and not 1.10 $\mathrm{mm}$.$) , and in the frontal avicularium occupying all the zooecial$ width.

We gave a summary in 1920 (p. 480, fig. 135) of our anatomical knowledge of this remarkable genus.

Occurrence.-Albatross Station D. 2387, Gulf of Mexico; $29^{\circ} 24^{\prime}$ $00^{\prime \prime}$ N.; $88^{\circ} 04^{\prime} 00^{\prime \prime}$ W.; 32 fms.; sand, gravel, broken shells.

Holotype.-Cat. No. 7479 , U.S.N.M.

\section{Genus SMITTINA Norman, 1903}

SMITTINA TRISPINOSA SPATHULATA Smitt, 1873

Plate 15, Figures 9-13; text Figure 21

1873. Escharella jacotina var. spathulata Smiтt, Floridan Bryozoa. Kongl. Svenska Vetenskaps-Akademiens Handlingar, vol. 10, p. 59. pl. 10, figs. 199, 200.

1914. Smittina trispinosa Osburn, Bryozoa of the Tortugas Islands. Publication Carnegie Institution, Washington, No.182, p. 208. (Local bibliography.)

Structure.-Our specimens creep over shells or sometimes are free and unilamellar. Never are they arranged on large flat surfaces, so

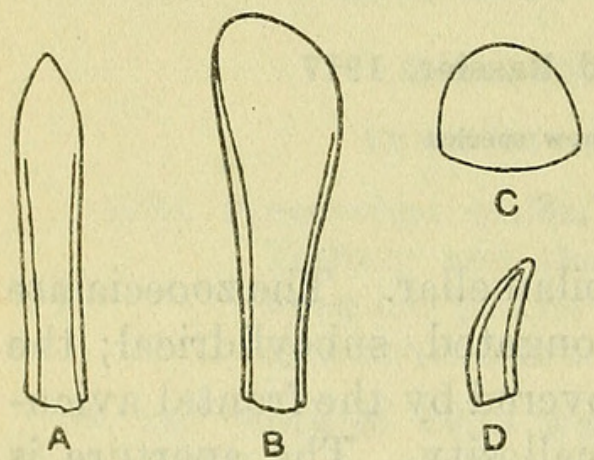

Fig. 21.-SMittina SPATHUlata SMitT, 1873. A, B. MANDIBLES OF LARGE AVICularia, $\times 85$. C. Operculum, $\times 85$. D. MANDIBLE OF SMALL AVICULARIUM, $\times 85$

(center and that their photography is quite difficult. They belong to the variety spathulata and we have not observed any other varieties, even the other variations described in the same latitudes by Osburn in 1912 and 1914. This variety is itself very irregular. We have figured the most characteristic opercula and mandibles.

The lyrule and the cardelles are placed on the proximal border of the aperture; they are placed above the operculum and remain visible on the specimens with ectocyst. The frontal is granulated at the center and surrounded by many rows of areolar pores. The latter are not visible at the interior, which is perfectly smooth at a magnification of 25 diameters. A thick pleurocyst covers the olocyst. 
The ovicell develops between the olocyst and the pleurocyst of the distal zooecium and shows all the characters of the frontal. This characteristic as well as the absence of an avicularium in the sinus of the peristomie would cause us to place this species in the genus $\mathrm{Mu}$ cronella, although this change would still not satisfy scientific exactness. Smittina irispinosa is a very cosmopolitan species which possesses powerful means of adaptation, a knowledge of which will reveal its very instructive biology. In our Philippine monograph we have tried to begin this work by putting some order in all the known varieties. In spite of the contrary opinion of Smitt, the variety spathulata is special to the Gulf of Mexico. The variety spathulata of MacGillivray and Kirkpatrick from Torres Strait differs notably in the position and form of the large avicularia.

Occurrence (var. spathulata only).-

Fowey Light, 15 miles south of Miami, Fla., $40 \mathrm{fms}$.

Albatross Station D. 2362, east of Yucatan; $22^{\circ} 08^{\prime} 30^{\prime \prime} \mathrm{N}$.; $86^{\circ} 53^{\prime} 30^{\prime \prime} \mathrm{W}$.; $25 \mathrm{fms}$.; coral sand.

Albatross Station D. 2365, east of Yucatan; $22^{\circ} 18^{\prime} 00^{\prime \prime}$ N.; $87^{\circ} 04^{\prime} 00^{\prime \prime} \mathrm{W}$.; $24 \mathrm{fms}$.; white rock coral.

Plesiotypes.-Cat. No. 7594, U.S.N.M.

SMITTINA ECHINATA, new species

Plate 28, Figures 2, 3

Description.-The zoarium is hollow, cylindrical, surrounding the delicate radicells of algae. It emits in every direction short conical or flabelliform branches forming an ensemble with the spiny aspect of Echinocava. The zooecia are distinct, separated by a furrow, short, elliptical; the frontal is convex and formed by a granular pleurocyst surmounting the olocyst; it is bordered with large areolar pores. The apertura is elliptical, orbicular, or transverse; it contains a small flat lyrule and two very small, very fragile cardelles. The oral avicularium is small and triangular with the beak oriented toward the top; it is placed to the right or to the left of the proximal border of the apertura. The ovicell is large, globular, perforated by some large pores. The pleurocyst does not cover it entirely and leaves a large circular area.

$$
\begin{array}{r}
\text { Measurements.-Apertura }\left\{\begin{array}{l}
h a=0.10 \mathrm{~mm} . \\
l a=0.10 \mathrm{~mm} .
\end{array}\right. \\
\text { Zooecium }\left\{\begin{array}{l}
L z=0.35 \mathrm{~mm} . \\
l_{z}=0.20 \mathrm{~mm} .
\end{array}\right.
\end{array}
$$

Affinities.-This species is extremely fertile, for on our specimens almost all of the zooecia are ovicelled. The peristone is thin and salient and is little visible on the ovicelled zooecia. The small zooecial dimensions and its curious colonies characterize this species very well. 
Biology. - The most fruitful species are not necessarily the most common. Smittina echinata is a good example of this, for only a few specimens have been found. The innumerable larvae are probably an easy prey for many marine organisms.

Occurrence.-Cedar Keys, Fla.

Cotypes.-Cat. No. 7596, U.S.N.M.

SMITTINA LABELLUM, new species

Plate 17, Figures 6-10; text Figures $22 a, g, h$

Description.-The zoarium encrusts small fragments of shells and corals and often consists of two superposed lamellae. The zooecia are distinct, separated by a salient thread, somewhat elongated, irregularly rectangular; the frontal is finely granular, bordered by scattered areolar pores, convex, formed of a tremocyst with very small pores (visible only under strong magnification). The apertura is small, suborbicular; a small lyrule and two minute cardelles are placed at the bottom of the peristomie; the peristome is thin, very salient, and bears two distal spines, two large lateral notched lips, and a proximal indentation forming a pseudorimule. The ovicell is large, globular, not as broad as the zooecia, adorned with a frontal area, finely granular. The frontal of the zooecia bears avicularia of variable size, oriented diversely with semicircular or spathulate mandibles.

$$
\begin{gathered}
\text { Measurements.- Apertura }\left\{\begin{array}{l}
h a=0.10 \mathrm{~mm} .(?) . \\
l a=0.10 \mathrm{~mm} .
\end{array}\right. \\
\text { Zooecium }\left\{\begin{array}{l}
L z=0.60-0.80 \mathrm{~mm} . \\
l z=0.50-0.60 \mathrm{~mm} .
\end{array}\right. \\
\text { Diameter of the ovicell }=0.35 \mathrm{~mm} . \\
\text { Length of the large avicularia }=0.35 \mathrm{~mm} .
\end{gathered}
$$

Variations.--Irregularity is the rule here, for no zooecium resembles its neighbor. The development of the apertural lips is very inconstant; they are very large in the protected portions; the exposed portions of the colony are deprived of them, but the peristome always exhibits two indentations - a proximal one in the pseudorimule and a distal one for the two spines. Certain zooecia have no avicularia; others have two or three; their form, position, orientation, and size are difficult of accurate description. Often a small triangular avicularium is adjacent to one of the peristomial lips; it is not clearly visible because of its position perpendicular to the zooecial plane.

Exteriorily the frontal does not appear perforated, and this species could be placed in the genus Smittina as we have defined it. However, in a special preparation it appears perforated by very small tremopores when they are examined at a suitable magnification 
( $\times 85)$; their diameter is in the neighborhood of six-thousandths of a millimeter $(0.006 \mathrm{~mm}$.)

Affinities.-This species differs from Smittina trispinosa Johnston, 1838 , in its larger dimensions, in the presence of two oral spines, and in the greater diameter $(0.35 \mathrm{~mm}$.) of its ovicell. It differs from Smittina tripora Canu and Bassler of the Philippines in the absence of two rather constant peristomial avicularia and in the presence of a large frontal avicularium.

The S. trispinosa group is very disconcerting in its zooecial irregularity and its false tremocyst. We were inclined to form a special genus for it, but we do not yet see any physiologic function which could differentiate it from other Smittina. However, it is a homogeneous group to the trained eye of the specialist. Smittia collaris, variety Waters, 1883, a fossil of the Miocene at Muddy Creek, Australia, is another species of the same group in which a small tongue sometimes replaces the distal spines.

Biology.-Our specimens were living and ovicelled January 19, 1885. The great irregularity of the avicularia is difficult to understand. It is difficult to admit that chance and fantasy are the only reasons for their presence; they are not ornaments but they are indeed special organs always in activity. Their appearance seems to be in connection with an immediate necessity, but essentially variable and changing, that each cell contributes to the profit of the colony.
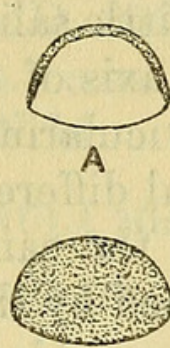

$\mathrm{B}$

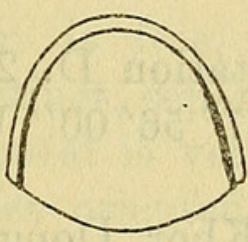

C

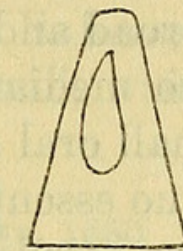

E

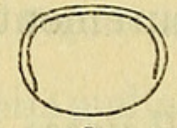

G

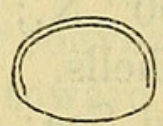

H

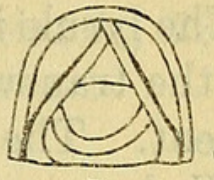

D)

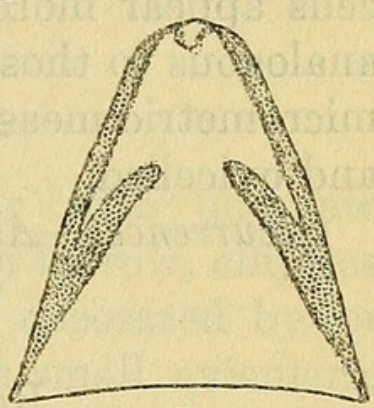

F

Fig. 22.-Family Smittinidae. A. Smitina labellum, NEW SPECIES. OPERCULUM, $X 85$ DOUBTFULLY REFERRED HERE. $B$. UMbONUlA UNDULATA, NEW SPECIES. OPERCUlum, $\times 85 . C, D$. Palmicellaria a viculifera, New SPECIES. C. Operculum, $\times 85$. D. MANDible, $\times 250$. $E, F$. RHAMPHOSTOMELLA MAGNIROSTRIS, NEW SPECIES, $E$. Mandible, $\times 85$. $F$. Large Mandible, $\times 85 . \quad G$. H. SMitTina LABELLUM, NEW SPECIES. TWO OPERCULA, $\times 85$

There is then an undoubted instinct, almost a kind of reasoning, permitting an adaption more easily to its environment.

Occurrence.-Albatross Station D. $2339 ; 23^{\circ} 10^{\prime} 40^{\prime \prime} \mathrm{N}$.; $82^{\circ} 20^{\prime}$ $15^{\prime \prime} \mathrm{W}$.; $191 \mathrm{fms}$.

Albatross Station D. 2639, Straits of Florida; $25^{\circ} 04^{\prime}$ $50^{\prime \prime} \mathrm{N}$.; $80^{\circ} 15^{\prime} 10^{\prime \prime} \mathrm{W}$.; $56 \mathrm{fms}$.; coral sand.

Florida, 21 and 71 meters (Smitt); Tortugas, low water, 20 meters (Osburn).

Cotypes.-Cat. No. 7560 , U.S.N.M. 


\section{Genus MUCRONELLA Hincks, 1880}

MUCRONELLA EGYPTIACA Waters, 1909

Plate 17, Figures 1-5

1909. Smittia egyptiaca Waters, Bryozoa from the Red Sea. Linnean Society's Journal, Zoology, vol. 31, p. 157, pl. 15, fig. 6, 9.

Measurements.-Aperture $\left\{\begin{array}{l}h a=0.10-0.12 \mathrm{~mm} . \\ l a=0.12 \mathrm{~mm} .\end{array}\right.$

$$
\text { Zooecia }\left\{\begin{array}{l}
L_{z}=0.40-0.60 \mathrm{~mm} \\
l_{z}=0.40 \mathrm{~mm} .
\end{array}\right.
$$

Affinities.-The colonies encrust probably small ramified algae; they have the aspect of small, hollow bifurcated tubes of $5 \mathrm{~mm}$. diameter. Because of this particular form the zooecia have variable micrometric measurements; our photographs represent the most regular cells.

The lyrule is broad and little salient; the small cardelles are almost on the transverse median axis of the aperture. The mucro is little salient. The small oral avicularium is very inconstant.

We have seen no essential differences from Water's species. If the cells appear more regular, the same colony bears others absolutely analogous to those illustrated by this author. In their ensemble, the micrometric measurements are identical. Our specimens were living and ovicelled.

Occurrence.-Albatross Station D. 2389, Gulf of Mexico; $29^{\circ} 28^{\prime}$ $00^{\prime \prime} \mathrm{N}$.; $87^{\circ} 56^{\prime} 00^{\prime \prime} \mathrm{W}$.; $27 \mathrm{fms}$.; gray sand, broken shells.

Red Sea; Khor Dongola; Engineer Island; Ras el Millau, Sinai Coast (Waters).

Plesiotypes.-Cat. No. 7561, U.S.N.M.

\section{Genus PALMICELLARIA Alder, 1864}

PALMICELLARIA AVICULIFERA, new species

Plate 17, Figures 14-16; text Figure $22 c, d$

Description.-The zoarium encrusts grains of hard clay. The zooecia are distinct, separated by a deep furrow, large, cylindrical; the frontal is smooth, very convex, surrounded by very small scattered areolar pores. The aperture is semielliptical and transverse, with a slightly concave proximal border; it is placed at the bottom of a deep peristomie; the peristome is thick, very salient; it bears a very salient round avicularium, without pivot, and four or five other smaller avicularia irregularly placed. The ovicell is large, globular, somewhat transverse, opening widely in the peristomie above the operculum. 


$$
\begin{gathered}
\text { Measurements.-Aperture (interior) }\left\{\begin{array}{l}
h a=0.15-0.20 \mathrm{~mm} \\
l a=0.20-0.25 \mathrm{~mm} .
\end{array}\right. \\
\text { Zooecia (interior) }\left\{\begin{array}{l}
L z=0.70-0.80 \mathrm{~mm} . \\
l z=0.40-0.50 \mathrm{~mm} .
\end{array}\right.
\end{gathered}
$$

Structure.-The operculum is very thin, bell-shaped; two long lateral bands placed very near the border serve as attachments for the muscles. The operculum and the mandible of the small peristomial avicularia have the aspect of those of Porella.

Affinities.-In the list of species of Palmicellaria which we published in 1923, we forgot a beautiful species from the English Crag, Palmicellaria (Lepralia) bicornis Busk, 1859. Our American species approaches it very closely but differs from it in its somewhat larger micrometric dimensions, in its larger and more salient ovicell, and in the presence of more than two accessory peristomial avicularia. Our specimens were in reproduction April 12, 1886.

Occurrence.-Albatross Station D. 2650, Bahama Islands; $23^{\circ} 34^{\prime}$ $30^{\prime \prime}$ N.; $76^{\circ} 34^{\prime} 00^{\prime \prime}$ W.; 369 fms.; coral sand, white ooze.

Cotypes.-Cat. No. 7565 , U.S.N.M.

\section{Genus UMBONULA Hincks, 1880}

UMBONULA UNDULATA, new species

Plate 17, Figures 11-13; text Figure $22 b$

Description.-The zoarium is free, bilamellar with undulated fronds. The zooecia are distinct, separated by a furrow, elliptical, somewhat elongated; the frontal is very convex, decorated by four or five pairs of large costules oriented toward a small avicularian umbo which covers the lyrule. The aperture is semielliptical, transverse, with rounded lateral angles; it is placed at the bottom of a short peristomie; the peristomice is transverse or elongated. The ovicell is globular, smooth, or costulated.

$$
\begin{array}{r}
\text { Measurements._Aperture }\left\{\begin{array}{l}
h a=0.12 \mathrm{~mm} . \\
l a=0.10 \mathrm{~mm} .
\end{array}\right. \\
\text { Zooecia }\left\{\begin{array}{l}
L z=0.50-0.60 \mathrm{~mm} . \\
l z=0.25 \mathrm{~mm} .
\end{array}\right. \text {. }
\end{array}
$$

Variations.-The avicularian umbo is not constant; it is often replaced by a sinus of the peristome at the bottom of which the lyrule is visible. The operculm is thickened, chitinous, golden yellow; it is semielliptical and the proximal border is straight or convex. The ovicells are very numerous on the colony and yet the species is very rare; the larvae probably do not know how to choose their substratum. 
The peristomice is much larger than the aperture; it opens the locella in which the operculm operates and which serves as a passage for the larvae.

Occurrence.-Cedar Keys, Fla.

Holotype.-Cat. No. 7610, U.S.N.M.

\section{Genus RHAMPHOSTOMELLA Lorenz, 1886}

RHAMPHOSTOMELLA MAGNIROSTRIS, new species

Plate 19, Figures 5-7; text Figure $22 e, f$

Description.-The zoarium is free, uni, or bi lamellar; the fronds are very irregular. The zooecia are little distinct, separated by a furrow, elongated, elliptical; the frontal is convex, bordered with areolar pores and ornamented with irregular costules. The aperture is large, elliptical, transverse, or suborbicular; the proximal border bears a wide lyrule placed eccentrically; the avicularian umbo is salient, arranged obliquely and partially covering the aperture. The ovicell is large, globular, formed of two calcareous lamellae and ornamented with punctations.

$$
\begin{gathered}
\text { Measurements.-Aperture }\left\{\begin{array}{l}
h a=0.25 \mathrm{~mm} . \\
l a=0.22 \mathrm{~mm} .
\end{array}\right. \\
\text { Zooecia }\left\{\begin{array}{l}
L z=0.75 \mathrm{~mm} . \\
l z=0.40 \mathrm{~mm} .
\end{array}\right.
\end{gathered}
$$

Variations.-The much calcified zooecia present fantastic forms; strong salient threads unite the ovicells, the frontal becomes concave, the lyrule disappears, the avicularian umbo is lacking, and it is replaced sporadically by an enormous avicularium with a large triangular mandible.

Affinities.-The genus Rhamphostomella is very common in the recent northern seas. Its presence in the Priabonian of the Vicentin, Italy, in the Jacksonian of the two Carolinas and of Georgia and in the Vicksburgian of Alabama proves that it can inhabit the warmer waters and approach the equatorial zone. Its presence in Florida confirms this observation deduced from paleontology.

In the form of its elliptical operculum this new species approaches Rhamphostomella cosiata Lorenz, 1886, but difiers from it in its free zoarium and its smaller and more irregular costules. It approaches more Rhamphostomella bilaminata Hincks, 1877, dredged more to the north in the American waters but differs from it in its large lyrule and in the presence of its large sporadic avicularia. The operculum is very thick, elliptical, little resembling the form of the aperture. Its margins are thin.

Occurrence.-Cedar Keys, Fla.

Cotypes.-Cat. No. 7579, U.S.N.M. 
Genus BRYOCRYPTELLA Cossmann, 1906

BRYOCRYPTELLA CONVEXA, new species

Plate 28, Figure 8

Description.-The zoarium encrusts fragments of shells. The zooecia are distinct, separated by a deep furrow, elongated, fusiform, very convex. The frontal is formed by an olocyst surmounted by a detachable pleurocyst and is surrounded by large areolar pores. The avicularian cavity forms a salient boss surrounded by five or six pores. The apertura is semicircular, without lyrule or cardelles. The avicularium is round, cylindrical, opening into the peristomie perpendicularly to the operculum. The ovicell is large, globular; the pleurocyst is often incomplete and then limits a circular area.

$$
\begin{array}{r}
\text { Measurements.-Aperture }\left\{\begin{array}{l}
h a=0.13 \mathrm{~mm} . \\
l a=0.15-0.20 \mathrm{~mm} .
\end{array}\right. \\
\text { Zooecium }\left\{\begin{array}{l}
L z=0.85-1.00 \mathrm{~mm} . \\
l z=0.40-0.60 \mathrm{~mm} .
\end{array}\right.
\end{array}
$$

Affinities.-The zooecial measurements are rather variable; the width increases when the length diminishes. The zooecial structure is absolutely identical with that of Bryocryptella torquata Jullien, 1903, from the Gulf of Gascogny, but the present species differs in its incrusting instead of arborescent colony. The structure of the ovicell being identical with that of the zooecial frontal, we can not class the genus in the family Escharellidae. Moreover, Jullien classed it in the family of Lepraliidae. Our specimens were dead and deprived of their chitinous appendages.

Occurrence.-Albatross Station D. 2650, Bahamas, 595 meters. Holotype.-Cat. No. 7463, U.S.N.M.

\section{BRYOCRYPTELLA RETICULATA, new species}

Plate 18, Figures 1-3

?1873. Retepora reticulata Smitr, Floridan Bryozoa. Kongl. Svenska Vetenskaps-Akademiens Handlingar, vol. 11, p. 69, pl. 13, figs. 242, 244.

Description.-The zoarium is free, reticulated, with wide meshes; the branches are formed by two longitudinal rows of cells. The zooecia are little distinct, very elongated, with finely granular surface. The peristomice is suborbicular; the apertura located at the bottom of a deep peristomie is not visible. A small avicularium is lodged in the proximal portion of the peristomie. The ovicell is very convex; its contours are indecisive; it opens into the peristomie.

Measuremients.-Peristomice, Diameter, 0.15-0.20 mm.

$$
\text { Zooecia }\left\{\begin{array}{l}
L z=0.70-0.80 \mathrm{~mm} . \\
l z=?
\end{array}\right.
$$

Affinities.-The indistinct zooecia and the reticulated zoarium distinguish this species clearly from Bryocryptella torquata Jullion, 
1903, and from Bryocryptella koehleri Calvet, 1896. Very probably Reticulipora reticulata Smitt, 1872, is the same species. However, Smitt figured a longitudinal slit on the ovicell and some vibices on the dorsal which we have not observed on our specimen.

Biology.-The two known species of this genus live in deep waters of the Gulf of Gascogny. Bryocryptella reticulata descends still lower.

Occurrence.-Albatross Station D. 2343, north of Cuba; $23^{\circ} 11^{\prime} 35^{\prime \prime}$

N.; $82^{\circ} 19^{\prime} 25^{\prime \prime}$ W.; 279 fms.; fine coral.

? Havana, 437 meters (Smitt).

Cotypes.-Cat. No. 7464 , U.S.N.M.

\section{Family RETEPORIDAE Smitt, 1867}

\section{Genus RETEPORA Imperato, 1599}

RETEPORA MARSUPIATA Smitt, 1873

Plate 18, Figures 7-13; text Figure $23 a$

1873. Retepora marsupiata Smits, Floridan Bryozoa. Kongl. Svenska Vetenskaps-Akademiens Handlingar, vol. 11, p. 67, pl. 13, figs. 245-254.

1904. Retepora marsupiata OsBurn, Bryozoa of the Tortugas Islands. Publication Carnegie Institution, Washington, No. 182, p. 200.

We have observed very few specimens of this beautiful species. They resemble especially Figures 252 and 253 of Smitt, and do not bear avicularia. However, the latter appear on some rare cells and we do not doubt that Smitt's observations are perfectly correct. We

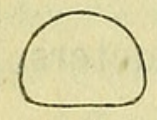

A

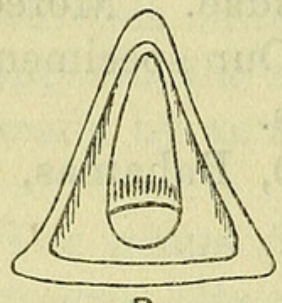

B

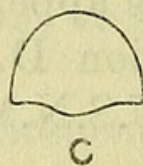

c

Fig. 23.-Appendages of Reteporidae. A. Retepora MARSUPiatA SMitT, 1873. OPERCULUM, $\times$ 85. $B, C$. SCHIZELlOZOON ELONGATUM, NEW SPECIES. $B$. MANDible of a frontal a VICUlarium, $\times 85$. C. OPERCUlum, $\times 85$

Biology.-Our specimens were in reproduction from January to March. "The color is a delicate pink" (Osburn). The bathymetric distribution of this species is very great.

Occurrence.-Albatross Station D. 2117, Caribbean Sea ; $15^{\circ} 24^{\prime} 40^{\prime \prime}$ N.; $63^{\circ} 31^{\prime} 30^{\prime \prime}$ W.; 683 fms.; yellow mud, fine sand.

Albatross Station D. 2411, Gulf of Mexico; $26^{\circ} 33^{\prime}$ $30^{\prime \prime} \mathrm{N}$.; $83^{\circ} 15^{\prime} 30^{\prime \prime} \mathrm{W}$.; 27 fnis.; fine white sand, black specks.

Florida, 16-424 meters (Smitt); Tortugas, 16-29 meters (Osburn).

Plesiotypes.-Cat. No. 7577, U.S.N.M.

doubt much, on the contrary, the exactitude of the synonymy indicated by Smitt and Osburn.

In our monograph on the bryozoa of the Philippines we have given a long study on the biology of the Retepores.

The operculum is thick, light colored, semicircular.

\section{(n)}




\section{Genus SCHIZELLOZOON Canu and Bassler, 1917}

\section{SCHIZELLOZOON GLONGATUM, new species}

Plate 19, Figures 1-4; text Figure $23 b, c$

Description.-The zoarium is bushy and reticulated; the branches have two or three longitudinal ranges of zooecia; the fenestrae are very long, very large, generally much wider than the branches. The dorsal is quite convex, finely granular; the vibices are very salient and form two rows of losanges irregularly alternating; two or three small orbicular avicularia appear on each losange. The zooecia are distinct, separated by a salient thread, elongated, very large, subhexagonal; the frontal is convex, very finely granular. The apertura is suborbicular, buried at the bottom of the peristomie, with a very broad proximal rimule. The peristomie is thin, salient, expanded, notched; in its proximal part is a reteporidian pore opening into the peristomie. The ovicell is convex, much elongated, adorned with a large longitudinal slit. The frontal bears two very small orbicular avicularia and sporadically a large, very salient, triangular acuminate avicularium with mandible turned toward the base.

$$
\begin{gathered}
\text { Measurements.-Apertura }\left\{\begin{array}{l}
h a=? \\
l a=0.12-0.13 \mathrm{~mm} .
\end{array}\right. \\
\text { Zooecium }\left\{\begin{array}{l}
L z=0.85-1.00 \mathrm{~mm} . \\
l z=0.60-0.70 \mathrm{~mm} .
\end{array}\right. \\
\text { Maximum length of fenestrae, } 8.00 \mathrm{~mm} . \\
\text { Diameter of branches, } 1.5 \mathrm{~mm} .
\end{gathered}
$$

Affinities.-The opercula were altered or absent on our specimens; we have not been able to make a good preparation and we have given only an approximate one. The large mandibles are triangular, much thickened, marginated, with a large proximal lucida.

Only Retepora wallichiana Hincks, 1877 , of the northern seas can be compared to the present species in the length of its fenestrae. It differs in its wider and more robust branches and in its large ovicellarian indentation.

Occurrence.-Albatross Station D. $2666 ; 30^{\circ} 47^{\prime} 30^{\prime \prime}$ N.; $79^{\circ} 49^{\prime}$ $00^{\prime \prime} \mathrm{W}$.; $270 \mathrm{fms}$.

Cotypes.-Cat. No. 7587, U.S.N.M.

\section{Genus RHYNCHOZOON Hincks, 1891}

\section{RHYNCHOZOON CORNIGER, new species}

Plate 34, Figure 6

Description.-The zoarium encrusts nullipores. The zooecia are distinct, separated by a furrow, much more elongated at the periphery than at the center of the colony. The frontal is convex, smooth, surrounded by large areolar pores. It bears above the aperture a very salient avicularium umbo and two smaller pedunculate cylin- 
drical avicularia. The aperture is elliptical, transverse; the proximal rimule is very broad and of little depth. The ovicell is large, convex, formed of two calcareous pellicules of which the superior is incomplete and limits a large irregular frontal area.

Measurements.-Aperture $\left\{\begin{array}{l}h a=0.07 \mathrm{~mm} . \\ l a=0.10 \mathrm{~mm} .\end{array}\right.$

$$
\text { Zooecia (marginal) }\left\{\begin{array}{l}
L z=0.50 \mathrm{~mm} . \\
l z=0.35 \mathrm{~mm} .
\end{array}\right.
$$

Affinities.-This new species differs from Rhynchozoon vaughani Canu and Bassler, 1923, from the Miocene at Bowden, Jamaica, in its much smaller dimensions. It differs from Rhynchozoon levigatum Canu and Bassler, 1923, from the Pleistocene at Mount Hope, Panama, in the presence of two small pedunculate avicularia.

Occurrence.-Pliocene: Minnitimmi Creek, Bocas Island, Almirante Bay, Panama.

Holotype.-Cat. No. 70854, U.S.N.M.

\section{Genus RETEPORELLA Busk, 1884}

RETEPORELLA PROMINENS, new species

Plate 18, Figures 4-6

Description.-The zoarium is free, arborescent; the branches are compressed, elliptical in section, dichotomous, formed of four longitudinal rows of cells. The zooecia are indistinct but slightly outlined by the vibices arranged in lozenge-shaped areas. The frontal is flat, finely granular. The peristomie is very salient, tubulose; the peristome is thick, orbicular, slashed. In the peristomie there is a small crown of very short and numerous spicules. The ovicell bears a longitudinal fissure; it is marginated. On the dorsal the vibices are arranged transversely; in the species thus outlined there are one or two very small rounded avicularia.

Measurements. -Diameter of peristome $=0.13-0.20 \mathrm{~mm}$.

Diameter of peristomice $=0.12 \mathrm{~mm}$.

Length of peristomie $=0.15-0.20 \mathrm{~mm}$.

Zooecia $\left\{\begin{array}{l}L z=0.75-0.85 \mathrm{~mm} . \\ l_{z}=0.35 \mathrm{~mm} .\end{array}\right.$

We are not able to determine the true form of the aperture nor that of the operculum. We have then classed this species in the zoarial genus Reteporella Busk, 1884, which remains as before a genus for uncertain species of this group.

Occurrence.-Albatross Station D. 2354, east of Yucatan; $20^{\circ} 59^{\prime}$ $30^{\prime \prime} \mathrm{N}$.; $86^{\circ} 23^{\prime} 45^{\prime \prime} \mathrm{W}$.; 130 fms.; coral.

Holotype.-Cat. No. 7578 , U.S.N.M. 


\section{Family STOMACHETOSELLIDAE Canu and Bassler, 1917}

\section{Genus CIG CLISUlA Canu and Bassler, 1927}

CIGClISUla SER RUATA Smitt, 1873

Plate 20, Figures 1-14; text Figure 24

1873. Porina serrulata Smitr, Floridan Bryozoa. Kongl. Svenska Vetenskaps-Akademiens Handlingar, vol. 11, p. 27, pl. 5, figs. 116-125.

$$
\begin{array}{r}
\text { Measurements. - Peristomice }\left\{\begin{array}{l}
h p=0.10-0.12 \mathrm{~mm} . \\
l p=0.10-0.12 \mathrm{~mm} .
\end{array}\right. \\
\text { Zooecia (interior) }\left\{\begin{array}{l}
L z=0.60-0.65 \mathrm{~mm} . \\
l_{z}=0.25-0.30 \mathrm{~mm} .
\end{array}\right.
\end{array}
$$

Structure and variations.-The zoarium is bilamellar; the fronds are narrow and bifurcate like the horns of a deer. The base is circular, little expanded, concave; it appears, therefore, to attach itself to small algae.

The marginal zooecia are distinct, elongated, covered with tubulal tremopores; the peristome is very salient, irregularly crenulated. They are transformed sometimes into large spatulate avicularia. The terminal zooecia of the fronds have also the same aspect. All the axial zooecia are indistinct and their frontal is ornamented with a complicated system of avicularia. The large spatulate avicularia give to the fronds the serrulate aspect characteristic of the species. They are inconstant and belong to the group of zoarial avicularia.

The ovicell is hyperstomial, opening into the peristomie above the operculum, developed between the olocyst and the tremocyst of the distal zooecium. It is not entirely covered over by the tremocyst; on its median longitudinal axis there is a narrow cribriform area formed by a double row of very short costules very variable in aspect. It is little apparent and immersed into the great thickness of the tremocyst.

The spiramen is very apparent on the young cells, on the marginal cells, and on the little calcified fronds. On the axial cells it is much less apparent and often difficult to observe. In longitudinal section it appears oblique and opens into the peristomie. According to Smitt, it is not covered by the ectocyst, which proves its hydrostatic function.

The small apertural avicularia are elliptical, with pivot, the beak turned toward the aperture. They are generally placed on the distal arch of the peristome. There is never more than one or two to a zooecium. Small analogous avicularia are developed sporadically on the frontal.

Large spatulate zooecial avicularia are placed obliquely on the frontal of all the axial zooecia; they are oval, variable in direction, the beak oriented toward the base. The distal orifice is small, oval, marginated. There is no proximal orifice, for the latter is closed by 
a small calcareous finely perforated membrane. In erecting themselves their mandible forces the water toward the aperture. Their presence is rather constant; however, certain rare groups of zooecia are deprived of them and the tremocyst appears as in the marginal zooecia.

Other rare groups of zooecia are covered by a sort of smooth: pleurocyst on which one or two avicularia subsist. This is not proof of old age, as Smitt wrote, for the group that we figure was placed on a young frond above the ordinary axial zooecia.

The aperture was figured by Smitt as semielliptical. On our photographs it appears for the most part as suborbicular and a little transverse. It is, moreover, rarely apparent and always buried at the bottom of the tremocystal peristomie. The operculum is very fragile, very thin, and of the same form as the aperture.

On the interior the zooecia are rather regular, smooth (olocyst), with rather thick walls. The spiramen appears in the portion cor-

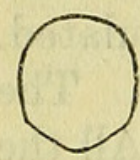

A

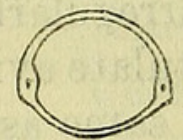

8

Fig. 24.-Cigchisula SERrU' LATA SMITT, 1877. $A, B$. OPERCULA, $\times 85$ responding to the external peristomie. The place and the true form of the aperture is more evident on the lateral zooecia.

Affnities.-Schizoporella cribrifera Hincks, 1885, and Schizoporella fisheri Jullien, 1882 , are ornamented with an analogous sievelike ovicell. They belong probably to the same family. Their aperture bears a proximal sinus which is lacking in Cigclisula serrulata.

This species differs very much from the genotype in the absence of the peristomial avicularia and in the form and nature of the operculum. It can in reality be considered as the type of a new genus of the same family, but as we know no closely allied species and as our information on the structure is still incomplete, we prefer to wait for a more complete study. This is the last representative of a family which was very important in the Gulf of Mexico of geologic time.

Occurrence.-Fowey Light, 15 miles south of Miami, Fla., $40 \mathrm{fms}$. Albatross Station D. 2639, Straits of Florida; $25^{\circ} 04^{\prime}$ $50^{\prime \prime} \mathrm{N}$.; $80^{\circ} 15^{\prime} 10^{\prime \prime} \mathrm{W}$.; $56 \mathrm{fms}$; coral sand.

Florida, 56-68 meters (Smitt).

Plesiotypes.-Cat. No. 7476 , U.S.N.M.

Family ADEONIDAE Jullien, 1903

Genus ADEONA (Lamouroux, 1816) Levinsen, 1909

ADEONA PLAGIOPORA Smitt, 1873

Plate 23, Figures 4,5

1873. Porina plagiopora Smitт, Floridian Bryozoa. Kongl. Svenska Veten skeps-Akademiens Handlingar, vol. 11, p. 30, pl. 6, figs. 134, 135. 
Measurements.-Peristomice $\left\{\begin{array}{l}h p=0.08 \mathrm{~mm} . \\ l p=0.10 \mathrm{~mm} .\end{array}\right.$

$$
\text { Zooecia }\left\{\begin{array}{l}
L z=0.50-0.60 \mathrm{~mm} . \\
l_{z}=0.30 \mathrm{~mm} .
\end{array}\right.
$$

Variations.-Our specimens are generally quite similiar to the figures of Smitt; we figure two variations-one around a gonoecium the other around the ancestrula.

Osburn, 1914 (p. 199), identified this species with Adeona violacea Johnston, 1847. He collected all the intermediate forms between the two species at the Tortugas, but on the contrary, our specimens do not have this variability, so that we have not been able to verify Osburn's synonymy. The ancestrula is small and reduced to the peristomie.

Occurrence.-Fowey Light, 15 miles south of Miami, Fla.; $40 \mathrm{fms}$. Albatross Station D. 2319, north of Cuba; $23^{\circ} 10^{\prime}$ $37^{\prime \prime} \mathrm{N}$.; $82^{\circ} 20^{\prime} 06^{\prime \prime} \mathrm{W}$.; $143 \mathrm{fms}$.; gray coral. Albatross Station D. 2324, north of Cuba; $23^{\circ} 10^{\prime}$ $25^{\prime \prime}$ N.; $82^{\circ} 20^{\prime} 24^{\prime \prime}$ W.; 33 fms.; coral.

Albatross Station D. 2405, Gulf of Mexico; $28^{\circ} 45^{\prime}$ $00^{\prime \prime} \mathrm{N}$.; $85^{\circ} 02^{\prime} 00^{\prime \prime} \mathrm{W}$.; $30 \mathrm{fms}$.; gray sand, broken coral.

Albatross Station D. 2639, Straits of Florida; $25^{\circ} 04^{\prime}$ $50^{\prime \prime} \mathrm{N}$.; $80^{\circ} 15^{\prime} 10^{\prime \prime} \mathrm{W}$.; 56 fms.; coral sand. Florida, 97 meters (Smitt); Bermuda (Verrill).

Plesiotypes.-Cat. Nos. 7448, 7449, U.S.N.M.

\section{Genus BRACEBRIDGIA MacGillivray, 1886}

\section{BRACEBRIDGIA SUBSULCATA Smitt, 1873}

Plate 23, Figures 1-3; text Figure 25

1873. Porina subsulcata Smits, Floridan Bryozoa. Kongl. Svenska Vetenskaps-Akademiens, Handlingar, vol. 11, p. 28, pl. 6, figs. 136-140.

1900. Porina subsulcata Verrill, Tunicata and Molluscoida of the Bermudas. Trans. Connecticut Academy, vol. 10, p. 54

1914. Bracebridgia subsulcata OsBURN, Bryozoa of the Tortugas Islands. Publication Carnegie Institution, Washington, No. 182, p. 199.

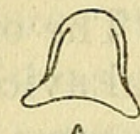

A

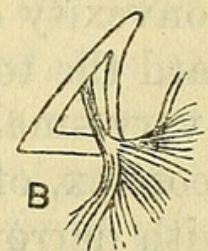

Fig. 25.-BRACEBRIDGIA SUBSULCATA SMITT, 1873. A. Operculum, $\times 85$. B. Mandible With MUSCles, $\times 85$. C. MANDible, $\times 85$

Structure.-It is with hesitation that Osburn, 1914, placed this species in Bracebridgia, for he believed he recognized trace of an ascopore on the frontal. We have prepared several interiors and have observed no traces of the ascopore, as the olocyst is perfectly smooth without any perforation. This species is evidently a Bracebridgia. 
The operculum is small, bell-shaped, with two lateral muscular attachments; it is attached inferiorily to the compensatrix without any trace of articulation. The mandible is triangular, dissymetric, unguiculated. The retractor muscle is very large, flabelliform, and formed of seven broad regular bundles.

The zoarium is much ramified; the fronds are dichotomous and develop like the horns of a deer.

Biology.-The color varies from yellowish pink to orange (Osburn). Our specimens are a yellowish gray. We have observed the expanded base.

Occurrence.-Albatross Station D. 2405, Gulf of Mexico; $28^{\circ} 45^{\prime}$ $00^{\prime \prime} \mathrm{N}$.; $85^{\circ} 02^{\prime} 00^{\prime \prime} \mathrm{W}$.; $30 \mathrm{fms}$.; gray sand, broken coral.

Fowey Light, 15 miles south of Miami, Fla.; $40 \mathrm{fms}$. Tortugas, 16-19 meters (Osburn); Florida, 16-77 meters (Smitt) and 763 meters; Bermuda (Verrill). Plesiotypes.-Cat. Nos. 7461, 7462, U.S.N.M.

\section{Family HIPPOPODINIDAE Levinsen, 1909}

Genus METRARABDOTOS Canu, 1914

METRARABDOTOS UNGUICULATUM, new species

Plate 23, Figures 6-9; text Figure 26

Description.-The zoarium is free, unilamellar, cylindrical, or conical. The zooecia are distinct, separated by a thread placed at the bottom of a furrow, large, much elongated, little broad; the frontal is convex, bordered laterally by areolar pores, formed of a pleurocyst with large granules. The aperture is transverse, semielliptical, little visible, arranged at the bottom of a peristomie. The peristomice is orbicular and provided with a proximal sinus; the peristome is thick and salient. At the side of the aperture and adjacent to the peristome there is a large falciform, long, thin, unguiculated avicularium with its convexity oriented toward the base of the zooecium and the beak toward the top. The ovicelled zooecia are much broader and bear two very small oral avicularia. The ovicell is enormous, endozooecial, convex, of the same structure as the frontal, and is ornamented with narrow, smooth, transverse callosities in the vicinity of its orifice.

Measurements.-Aperture (interior) $\left\{\begin{array}{l}h a=0.10 \mathrm{~mm} . \\ l a=0.20 \mathrm{~mm} .\end{array}\right.$

$$
\begin{aligned}
& \text { Peristomice }\left\{\begin{array}{l}
h p=0.20 \mathrm{~mm} . \\
l p=0.15 \mathrm{~mm} .
\end{array}\right. \\
& \text { Zooecia }\left\{\begin{array}{l}
L z=1.00 \mathrm{~mm} . \\
l z=0.50 \mathrm{~mm} .
\end{array}\right.
\end{aligned}
$$

Variations.-As on all the giant species, the micrometric variations are quite variable. Our measurements are average, as there are 
some large and some smaller cells. The smaller cells are frequently deprived of avicularia.

The peristome is indented by a rimule spiramen but the ovicelled zooecia do not bear one and probably have no polypide. Our specimens, unfortunately not being preserved in alcohol, we have been unable to study their anatomy. On the interior there are parietal dietellae as in the Adeonidae. By transparency, there are large interareolar costules and a kind of lyrule often garnishes the spiramen sinus of the peristome. The ovicell bears two pores invisible exteriorily.

Two flabelliform inuscular bundles move the mandible, which is strongly chitinized on the borders.

Biology.-The colony frequently encrusts radicells of algae which give to it its tubular appearance. They creep also on nullipores and on Serpulae and cover large surfaces. Many lamellae are sometimes superposed.

The color is rose, reddish purple, or reddish violet.

Affinities.-At first glance this species may be confused with Schizopodrella floridana Osburn, 1914 , but differs from it in its large endozooecial ovicell, in its pleurocystal and not tremocystal frontal, and in its avicularium with inferior (and not superior) concavity. Its large unguiculated avicularium differenciates it from all the other known species.

The genus Metrarabdotos is much developed

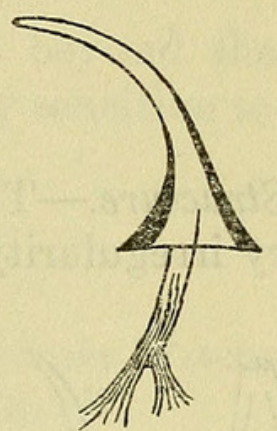

Fig. 26.-METRARABDOTOS UNGUICULATUM, NEW SPECIES. MANDIBLE, $\times 85$, OF ORAL AVICULARIUM WITH TWO BUNDLES OF MUSCULAR FIBERS in the American Miocene and Pliocene. We have described several very beautiful and vigorous species, but in which the fronds are always free and bilamellar.

The discovery of a recent well-developed species of this genus, much developed on both sides of the Atlantic during the long geologic periods, is very fortunate. When it is more studied, the paleontolo_ gist will understand better the life conditions of the ancient seas.

The genus Metrarabdotos is not really an equatorial genus. It lives in the vicinity of the Tropics but it does not go beyond this area.

Occurrence.-Albatross Station D. 2363, east of Yucatan; $22^{\circ} 07^{\prime}$ $30^{\prime \prime} \mathrm{N}$.; $87^{\circ} 06^{\prime} 00^{\prime \prime} \mathrm{W}$.; 21 fms.; white rock coral. Albatross Station D. 2405, Gulf of Mexico; $28^{\circ} 45^{\prime}$ $00^{\prime \prime} \mathrm{N}$.; $85^{\circ} 02^{\prime} 00^{\prime \prime} \mathrm{W}$.; $30 \mathrm{fms}$.; gray sand, broken coral.

Albatross Station D. 2639, Straits of Florida; $25^{\circ} 04^{\prime}$ $50^{\prime \prime} \mathrm{N} . ; 80^{\circ} 15^{\prime} 10^{\prime \prime} \mathrm{W}$.; 56 fms.; coral sand.

Cotypes.-Cat. No. 7556 , U.S.N.M. 
Genus HIPPALIOSINA Canu, 1918

HIPPALIOSINA ROSTRIGERA Smitt, 1873

Text Figure 27

1873. Escharella rostrigera Smitт, Floridan Bryozoa. Kongl. Svenska Vetenskaps Akademiens, Handlingar, vol. 11, p. 57, pl. 10, figs. 203-205.

1914. Lepralia rostrigera OsBuRn, Bryozoa of Tortugas Islands. Publication Carnegie Institution of Washington, No. 182, p. 211. (Not Waters, 1885, Jelly, 1889.)

1923. Hippalinsina rostrigera Cand, and Bassler, North American Later Tertiary and Quaternary Bryozoa. Bull. 125, U. S. National Museum, p. 167, pl. 17, figs. 15-17.

Measurements.-Apertura $\left\{\begin{array}{l}h a=0.11 \mathrm{~mm} . \\ l a=0.10 \mathrm{~mm} \text {. }\end{array}\right.$

Zooecia (ordinary) $\left\{\begin{array}{l}L z=0.44-0.46 \mathrm{~mm} \\ l z=0.26 \mathrm{~mm} .\end{array}\right.$

Aperture (ovicelled zooecia) $\left\{\begin{array}{l}h a=0.12 \mathrm{~mm} \text {. } \\ l a=0.14 \mathrm{~mm} \text {. }\end{array}\right.$

Zooecia (ovicelled) $\left\{\begin{array}{l}L z=0.60 \mathrm{~mm} . \\ l z=0.30 \mathrm{~mm} .\end{array}\right.$

Structure.-The opercula of the ordinary zooecia are of extraordinary irregularity and their ornamentation is very transparent and
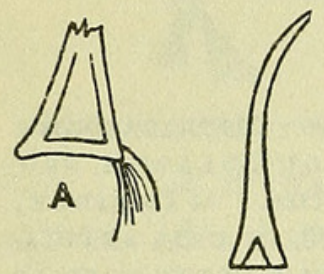

B
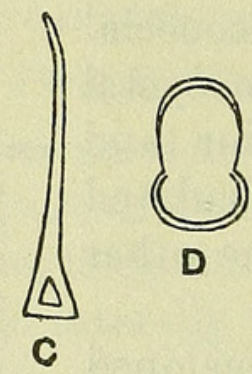

D

E difficult to observe. The distal margin is thick and there are two lateral bands very close to the border. The mandibles are also very variable. Some are very short and others long and setiform. They are always unguiculate. The frontal

Fig. 27.-Hippaliosina rostrigera Smitt, 1873. A-C. DIFFERENT FORMS OF THE SETIFORM MANDIBLE OF THE avicularium. $D, E$. Opercula, $\times 85$ seen by transparency shows the large areolar pores and the pleurocystal granules (sketched in black).

The natural history of the genus Hippaliosina is still very incomplete, for the larva and the anatomy are still awaiting description.

Biology.-Our specimens encrust Pectens and Nullipores while Osburn's examples grew on corals and shells. This species appears to prefer coral bottoms. It was in reproduction on March 15, 1885. Its longevity is very great, for we have discovered it in the Middle Miocene of Virginia. It has never left the Gulf of Mexico.

Occurrence.-Albatross Station D. 2319, north of Cuba; $23^{\circ} 10^{\prime} 37^{\prime \prime}$ N.; $82^{\circ} 20^{\prime} 06^{\prime \prime} \mathrm{W} . ; 143$ fms.; gray coral.

Albatross Station D. 2405, Gulf of Mexico; $28^{\circ} 45^{\prime}$ $00^{\prime \prime}$ N.; $85^{\circ} 02^{\prime} 00^{\prime \prime} \mathrm{W}$.; 30 fms.; gray sand; broken coral.

Florida, 56-69 meters (Smitt); Tortugas, 16-24 meters (Osburn).

Plesiotypes.-Cat. No. 7524, U.S.N.M. 


\section{Genus TREMOSCHIZODINA Duvergier, 1921}

1921. Tremoschizodina Dụvergier, Bryozoaires du Néogene de l'Aquitane. Actes de la Société Linneénne de Bordeaux, ser. 72, p. 36.

The ovicell is endozooecial. The aperture has a very broad proximal sinus. The frontal is a tremocyst surmounting a thin olocyst. The avicularium is parietal and very rare.

Genotype.-Tremoschizodina pisciformis Duvergier, 1921 (Miocene). Range.-Miocene (Helvetian)-Recent.

This remarkable genus was discovered by Duvergier, in the Helvetian in the vicinity of Bordeaux, France. We have observed that Gemellipora lata Smitt, 1873, belongs to the same genus. Finally we discovered a magnificent and vigorous species in the Philippines, Tremoschizodina crassa, living in the Sulu Archipelago and in the China Sea. •

This is an equatorial genus but passes somewhat beyond the line of the Tropics. The species appear to be extremely sensitive to cold and can not live at a temperature less than $9^{\circ} \mathrm{C}$.

\section{TREMOSCHIZODINA LATA Smitt, 1873}

Plate 21, Figures 1, 2; text Figure 28

1873. Gemellipora lata Smiтt, Floridan Bryozoa. Svenska VetenskapsAkademiens Handlingar vol. 11, p. 36, pl. 7, fig. 157.

Measurements.-Aperture $\left\{\begin{array}{l}h a=0.16 \mathrm{~mm} . \\ l a=0.13 \mathrm{~mm} .\end{array}\right.$

Aperture (ovicelled) $\left\{\begin{array}{l}h a=0.14 \mathrm{~mm} . \\ l a=0.18 \mathrm{~mm} .\end{array}\right.$

Zooecia $\left\{\begin{array}{l}L z=0.50 \mathrm{~mm} \\ l z=0.36 \mathrm{~mm}\end{array}\right.$

Structure.-Smitt found only a single nonovicelled specimen. Fortunately, we have had the chance to discover the ovicell. It is endozooecial, small, and somewhat convex. This species must, therefore, be classed in the genus Tremoschizodina Duvergier, 1921.

The apertura figured by Smitt is perfectly exact. That of the ovicelled zooecia is somewhat larger, elliptical, and transverse. The operculum is formed of two parts corresponding to the anter and

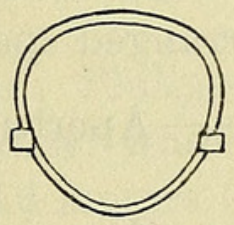

A

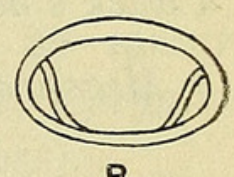

B

Fig. 28.-Tremoschizodina lata Smitt, 1873. A. OPERCULUM OF ORDINARY ZOOECIA, $X 85$. b. OPERCULUM OF OVICELLED ZOOECIA, $\times 85$ poster and bordered interiorily by a sclerite on which the opercular muscles are probably attached; there is no other ornament visible. It is yellow colored and strongly chitinized. The axis of rotation is formed by two chitinous cardelles, a phenomenon rather rare in the Cheilostomata.

The frontal is formed of an olocyst surmounted by a detachable and very thin tremocyst. On the young zooecia the frontal forms a very 
pretty mosaic. At the center of each polygon there is a small tubular very oblique pore. In transparency, the tremopores are widely spaced. On the interior, the zooecial walls are very thin. The tremopores are very small and little visible.

Biology.-The zoarium encrusts dead shells, corals, nullipores, and bryozoa.

Our specimens are yellow colored. Smitts specimen "had a yellowish color, with the zooecial aperture, through their covering membrane and operculum of a darker greenish-yellow tint" (Smitt).

The specimens dredged alive were in reproduction March 15, 1885.

The colonies are always very small and we have not been able to study the avicularia.

Occurrence.-Albatross Station D. $2152,21 / 2$ miles northwest of Habana Light; 387 fms.; coral.

Albatross Station D. 2405, Gulf of Mexico; $28^{\circ} 45^{\prime}$ $00^{\prime \prime} \mathrm{N}$.; $85^{\circ} 02^{\prime} 00^{\prime \prime} \mathrm{W}$.; $30 \mathrm{fms}$.; gray sand, broken coral.

Albatross Station D. 2639, Straits of Florida; $25^{\circ} 04^{\prime}$ $50^{\prime \prime} \mathrm{N}$.; $80^{\circ} 15^{\prime} 10^{\prime \prime} \mathrm{W}$.; 56 fms.; coral sand.

Fowey Light, 15 miles south of Miami, Fla.; $40 \mathrm{fms}$. Florida, 110 meters (Smitt).

Plesiotype.-Cat. No. 7604, U.S.N.M.

\section{TREMOSCHIZODINA ANATINA, new species}

Plate 33, Figure 10

Description.-The zoarium is incrusting. The zooecia are distinct, separated by a deep furrow, elongated, subrectangular; the frontal is convex, striated transversely, perforated by very small and much scattered pores. The apertura is suborbicular or somewhat transverse; two small points separate the anter from a concave rimule, very broad and little distinct. There are large avicularia shaped like a duck's beak arranged sporadically between the zooecia.

$$
\begin{gathered}
\text { Measurements.-Aperture }\left\{\begin{array}{l}
h a=0.15-0.17 \mathrm{~mm} . \\
l a=0.17 \mathrm{~mm} .
\end{array}\right. \\
\text { Zooecia }\left\{\begin{array}{l}
L z=0.75-0.85 \mathrm{~mm} . \\
l z=0.40-0.50 \mathrm{~mm} .
\end{array}\right. \\
\text { Avicularia }\left\{\begin{array}{l}
L a v=0.85 \mathrm{~mm} . \\
l a v=0.25 \mathrm{~mm} .
\end{array}\right.
\end{gathered}
$$

Affinities.-This new species differs from the recent Tremoschizodina lata Smitt, 1873, in which the frontal and the aperture are identical in its larger dimensions and in the presence of a large interzooecial avicularium. Tremoschizodina pisciformis Duvergier, 1921, of the French Miocene (genotype) and the recent Tremoschizodina crassa Canu and Bassler from the Philippines have a frontal with tremopores and a zooecial avicularium. The form of the aperture of the first is 
clearly schizoporoid and somewhat different from the apertural form of the other species.

The genus Tremoschizodina is therefore not yet perfectly limited. Very few specimens have been found and we have not been able to make tangential sections necessary for a more complete study. It is a tropical genus.

Occurrence.-Pliocene: Minnitimmi Creek, Bocas Island, Almirante Bay, northwest Panama.

$$
\text { Holotype.-Cat. No. 70866, U.S.N.M. }
$$

\section{Genus HIPPOPODINA Levinsen, 1909}

\section{HIPPOPODINA FEEGENSIS Busk, 1884}

Plate 34, Figures 1, 2

1913. Lepralia feegensis Watens, Bryozoa from Zanzibar. Proceedings Zoological Society, London, p. 514, pl. 70, figs. 21, 22. (Bibliography.) Not Lepralia feegensis MacGillivray.

Variations.-The operculum figured by Waters, 1913, indicates oral dimensions of 0.22 by $0.19 \mathrm{~mm}$. The aperture figured by Levinsen, 1909 , measures 0.18 to $0.20 \mathrm{~mm}$. in diameter or 0.21 by $0.19 \mathrm{~mm}$. The aperture on our specimen is 0.21 by $0.19 \mathrm{~mm}$. or 0.25 by 0.22 $\mathrm{mm}$; it is, then, slightly larger. All the other characters are quite identical with those which can be observed on the excellent figures of Busk and of Levinsen. Our determination appears to us perfectly exact.

This is a tropical species observed from the African coast to the Philippine Islands in the Indian Ocean. Its presence has not yet been noted in the Gulf of Mexico, where it may perhaps be found some day. Scrupocellaria retiformis Smitt, 1872, has an analogous geographic distribution and we have noted its occurrence as a fossil in Panama and as a living species in the Gulf of Mexico.

Occurrence.-Pliocene: Minnitimmi Creek, Bocas Island, Almirante Bay, northwest Panama.

Geographic distribution.-Indian Ocean: Philippines, 29 meters (Busk); Hongkong, Sifu (Philipps); Manaar; Andamans; Cargados (Thornely); Wasin, British East Africa, 16 meters (Waters).

Plesiotype.-Cat. No. 70842, U.S.N.M.

\section{Family CREPIDACANTHID王 Levinsen, 1909}

\section{Genus MASTIGOPHORA Hincks, 1880}

MASTIGOPHORA PESANSERIS Smitt, 1873

Plate 21, Figure 9; Plate 34, Figure 4

1873. Hippothoa pesanseris Smitr, Floridan Bryozoa. Kongl. Svenska Vetenskaps-Akademiens, Handlingar, vol. 11, p. 43, pl. 7, figs. 159, 160.

1914. Escharina pesanseris OsBurn, Bryozoa of the Tortugas. Publication Carnegie Institution, Washington, No. 182, p. 207. 
Measurements.-Aperture $\left\{\begin{array}{l}h a=0.12 \mathrm{~mm} . \\ l a=0.08-0.09 \mathrm{~mm} .\end{array}\right.$

$$
\text { Zooecia }\left\{\begin{array}{l}
L z=0.60-0.70 \mathrm{~mm} . \\
l z=0.50 \mathrm{~mm} .
\end{array}\right.
$$

Our specimens were dead when dredged; one of them was green. We have figured the best preserved.

This species is rather cosmopolitan. We rediscovered it in the Philippines and have indicated the principal variations.

Occurrence.-Albatross Station D. 2319, north of Cuba; $23^{\circ} 10^{\prime}$ $37^{\prime \prime} \mathrm{N}$.; $82^{\circ} 20^{\prime} 06^{\prime \prime} \mathrm{W}$.; 143 fms.; gray coral. Albatross Station D. 2639, Straits of Florida; $25^{\circ} 04^{\prime}$ $50^{\prime \prime}$ N.; $80^{\circ} 15^{\prime} 10^{\prime \prime} \mathrm{W}$.; 56 fms.; coral sand.

Fowey Light, 15 miles south of Miami, Fla.; $40 \mathrm{fms}$. Tortugas, 13 meters (Osburn), 68 meters (Smitt).

Pliocene, Minnitimmi Creek, Bocas Island, Almirante Bay, Panama.

Plesiotypes.-Cat. Nos. 7545, 7546, U.S.N.M.

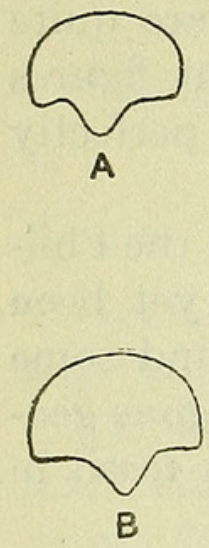

MASTIGOPHORA POROSA Smitt, 1873

Plate 19, Figures 8, 9; text Figure 29

1873. Hippothoa porosa Smite, Floridan Bryozoa. Kongl. Svenska Vetenskaps-Akademiens, Handlingar, vol. 11; p. 41, pl. 7, fig. 158.

$$
\text { Measurements.-Aperture }\left\{\begin{array}{l}
h a=0.10 \mathrm{~mm} \\
l a=0.14 \mathrm{~mm} .
\end{array}\right.
$$

$$
\text { Zooecia }\left\{\begin{array}{l}
L z=0.70-0.80 \mathrm{~mm} . \\
l z=0.45-0.90 \mathrm{~mm} .
\end{array}\right.
$$

Structure--Our colonies are small and rare in each locality. The operculum is thin with a broad triangular rimule. The mandible of the vibraculum is setiform and short; it moves obliquely. The ovicell is very short and of the same structure as the frontal.

Biology.-The specimens encrust nullipores,

FIG. 29.-MASTIG OPHORA PoRosa SMITT, 1873. $A, B$. SMALL AND LARGE OPERCULA, $\times$ 85. $C$. SETIFORM MANDIBLE, $\times 85$

shells, and corals. They are yellow or old rose in color. They were in reproduction January $15,1885$.

Occurrence.-Albatross Station D. 2405, Gulf of Mexico; $28^{\circ} 45^{\prime}$ $00^{\prime \prime} \mathrm{N}$.; $85^{\circ} 02^{\prime} 00^{\prime \prime} \mathrm{W}$.; $30 \mathrm{fms}$.; grays and, broken coral.

Albatross Station D. 2639, Straits of Florida; $25^{\circ} 04^{\prime}$ $50^{\prime \prime}$ N.; $80^{\circ} 15^{\prime} 10^{\prime \prime}$ W.; 56 fms.; coral sand.

Fowey Light, 15 miles south of Miami, Fla.; $40 \mathrm{fms}$. Florida, 64-113 meters (Smitt).

Blake Expedition, between Jamaica and Cuba; $18^{\circ}$ $22^{\prime}$ N.; $89^{\circ} 21^{\prime}$ W. (Norman, 1909).

Plesiotype.-Cat. No. 7547, U.S.N.M. 


\section{Genus CREPIDACANTHA Levinsen, 1909}

\section{CREPIDACANTHA SETIGERA Smitt, 1873}

Plate 21, Figure 10

1873. Hippothoa setigera Smits, Floridan Bryozoa. Kongl. Svenska Vetenskaps-Akademiens, Handlingar, vol. 11, p. 58, pl. 15, fig. 206.

Measurements.-Aperture $\left\{\begin{array}{l}h a=0.10 \mathrm{~mm} \\ l a=0.08 \mathrm{~mm}\end{array}\right.$

$$
\text { Zooecia }\left\{\begin{array}{l}
L_{z}=0.60 \mathrm{~mm} \\
l_{z}=0.45-0.50 \mathrm{~mm} .
\end{array}\right.
$$

Affinities.-This species differs from Crepidacantha grandis, discovered by us in the Philippines, only in the absence of a small oral mucro and in the much smaller dimensions of the aperture. Very probably it is the same species.

Smitt discovered only one specimen deprived of its marginal spines but ornamented with its setiform mandibles somewhat shorter than the zooecia. Our specimen is still more incomplete. The comparison with other species is therefore necessarily difficult and uncertain. The colonies encrust fragments of shells.

Occurrence.-Albatross Station D. 2639, Straits of Florida; $25^{\circ} 04^{\prime}$ $50^{\prime \prime} \mathrm{N}$.; $80^{\circ} 15^{\prime} 10^{\prime \prime} \mathrm{W}$.; $56 \mathrm{fms}$; coral sand.

Tortugas Islands, 97 meters (Smitt)

Plesiotype.-Cat. No. 7827, U.S.N.M.

\section{CREPIDACANTHA LONGISETA, new species}

Plate 21, Figures 3, 4

Description.-The zoarium encrusts corals and hydroids. The zooecia are distinct, separated by a deep furrow, elongated, pyriform; the frontal is convex, smooth, or granular, bordered laterally by linear pores and by 11 very long marginal spines. The aperture is small, suborbicular, formed of a semicircular anter and a small concave poster separated by two very short cardelles; the peristome is broad, little salient, with a small mucro in its proximal part. The ovicell is large, globular, placed on the zooecium itself, closed by the operculum; the pleurocyst which covers the olocyst is incomplete and leaves a frontal area. On each side of the aperture there is a small avicularium; the setiform mandible is longer than the zooecium and very flexible.

$$
\begin{array}{r}
\text { Measurements.-Aperture }\left\{\begin{array}{l}
h a=0.10 \mathrm{~mm} . \\
l a=0.10 \mathrm{~mm} .
\end{array}\right. \\
\text { Zooecia }\left\{\begin{array}{l}
L z=0.44 \mathrm{~mm} . \\
l z=0.34 \mathrm{~mm} .
\end{array}\right.
\end{array}
$$

Affinities.-This new species differs from Crepidacantha poissonii Savigny-Audouin, 1826, in its avicularia placed on each side of the aperture and not below it. It differs from Crepidacantha setigera Smitt, 1873, in its smaller dimensions and its long retiform mandible. 
Biology.-This species was in reproduction from the month of January to the month of May, according to the dredgings of the Albatross.

Occurrence.-Albatross Station D. 2167, off Habana, Cuba; $23^{\circ}$ $10^{\prime} 40^{\prime \prime}$ N.; $82^{\circ} 20^{\prime} 30^{\prime \prime}$ W.; $201 \mathrm{fms}$.; coral.

Albatross Station D. 2169 , off Habana, Cuba; $23^{\circ} 10^{\prime}$ $28^{\prime \prime} \mathrm{N}$.; $82^{\circ} 21^{\prime} 27^{\prime \prime} \mathrm{W}$.; $78 \mathrm{fms}$; ; coral.

Albatross Station D. 2334, north of Cuba; $23^{\circ} 10^{\prime}$ $42^{\prime \prime}$ N.; $82^{\circ} 18^{\prime} 24^{\prime \prime}$ W.; $67 \mathrm{fms}$; white coral.

Holotype.-Cat. No. 7826, U.S.N.M.

\section{CREPIDACANTHA POISSONII Savigny-Audouin, 1826}

Plate 34, Figure 3

1826. Flustra poissonii Audourn, In Savigny's Description de l'Egypt. Histoire Naturelle, vol. 1, p. 10, fig. 5 .

1880. Lepralia kirchenpaueri var. teres Hincks, Contribution history Marine Polyzoa. Annals and Magazine of Natural History, ser. 5, vol. 6, p. 77 (sep. 9), pl. 9, fig. 7 .

1885. Lepralia kirchenpaueri var. teres Hıncks, Contribution history Marine Polyzoa. Annals and Magazine of Natural History, ser. 5, vol. 15, p. 256 (sep. 166).

1899. Lepralia poissonii WAters, Bryozoa from Madeira. Journal Royal Microscopical Society, p. 16.

1909. Lepralia poissonii Norman, The Polyzoa of Madeira. Linnean Society's Journal-Zoology, vol. 30, p. 307, pl. 41, figs. 7, 8. Not Kirkpatrick, 1888; MacGillivray, 1882; Levinsen, 1909.

Under the name of Lepralia poissonii, the authors have manifestly confused many species and it is necessary to rename them. The specific characteristic is furnished by the position of the setiform avicularia, which are always removed from the aperture and placed much lower. In all the other species they are always placed at the side of the aperture, and if lower, on a level with the proximal border. There is no other synonymy than that which we indicate.

The specimens from the Red Sea have costulated ovicells; those from Madeira and from the Gulf of Mexico are smooth, without frontal area.

This interesting species is represented in the Pliocene deposits of Panama by a variation which presents no characters essentially different from the species.

The two vibracula are not placed symmetrically on the frontal.

Affinities.-Crepidacantha is a genus of the Tropics and of the southern part of the Temperate Zone. Many species are known. They are characterized by their micrometric dimensions and especially by the position of the two oral vibracula. In Crepidacantha poissonii 
these are always placed symmetrically below the aperture. The figures of Savigny and Norman agree perfectly in showing this essential character. On our fossil specimens from Panama the vibracula are rarely placed at the same height. Almost always there is one more removed from the aperture, but both are always below the aperture as in the type.

In the two other species from the Gulf of Mexico, C. setigera Smitt, 1873 , and $C$. longiseta, new species, the vibracula are placed on each side of the aperture.

Occurrence.-Madeira, Hawaiian Islands, etc. (type form).

Pliocene: Minnitimmi Creek, Bocas Island, Almirante Bay, northwest Panama.

Holotype-Cat. No. 70835, U.S.N.M.

Family PHYLACTELLIDAE Canu and Bassler, 1917

Genus LAGENIPORA Hincks, 1877

LAGENIPORA VERRUCOSA, new species

Plate 21, Figures 5-8

Description.-The zoarium encrusts shells, nullipores, corals, and hydroids; the zooecia are arranged in uniserial lines more or less ramified. The zooecia are long, lageniform; the frontal is convex, verrucose, and terminated by a long cylindrical smooth peristome. The aperture is orbicular and buried at the bottom of the peristome; the peristome is thin, entire, or notched. The ovicell is small, globular, opening into the peristome above the operculum.

Measurements.-Diameter of peristome $=0.20 \mathrm{~mm}$.

$$
\text { Zooecia }\left\{\begin{array}{l}
L_{z}=0.55 \mathrm{~mm} . \\
l z=0.30-0.35 \mathrm{~mm} .
\end{array}\right.
$$

Structure.-This curious species is rather variable. There are some very verrucose zooecia and others which are almost smooth. The length of the peristome depends upon its position on its substratum. The branches are irregular in their divergence; they have a tendency to approach each other and the cells group themselves sometimes in the manner of cellepores, but without ever surmounting each other.

Affinities.-Lagenipora edwardsi Jullien, 1882, is also uniserial, but our species differs in its smaller zooecia and its long peristomes.

Biology.-This is a species of the coral bottoms and of submarine currents; it descends to rather great depths. It is fond of small round bodies for a substratum and it twists about them in all directions. The choice made by the larva is a beautiful manifestation of their instinct. The photography of the colonies thus fixed is very difficult. 
Occurrence.-Albatross Station D. 2320 , north of Cuba; $23^{\circ} 10^{\prime}$ $39^{\prime \prime}$ N.; $82^{\circ} 18^{\prime} 48^{\prime \prime}$ W.; 130 fms.; fine coral.

Albatross Station D. 2324, north of Cuba; $23^{\circ} 10^{\prime} 25^{\prime \prime}$ N.; $82^{\circ} 20^{\prime} 24^{\prime \prime}$ W.; 33 fms.; coral.

Albatross Station D. 2639, Straits of Florida; $25^{\circ} 04^{\prime}$ $50^{\prime \prime} \mathrm{N}$.; $80^{\circ} 15^{\prime} 10^{\prime \prime} \mathrm{W}$.; $56 \mathrm{fms}$.; coral sand. Albatross Station D. 2319, north of Cuba; $23^{\circ} 10^{\prime}$ $37^{\prime \prime} \mathrm{N}$.; $82^{\circ} 20^{\prime} 06^{\prime \prime} \mathrm{W}$.; $143 \mathrm{fms}$.; gray coral.

Cotypes.-Cat. Nos. 7534, 7535, U.S.N.M.

\section{Family CELLEPORIDAE Busk, 1852}

\section{Genus HIPPOPORIDRA Canu and Bassler, 1927}

The ovicell is hyperstomial and bears a frontal area. The zooecia are accumulated; the frontal is surrounded by areolar pores and often bears small avicularia. The aperture is formed of an anter and a poster separated by two cardelles. The large interzooecial avicularia are acuminated.

Genotype.-Hippoporidra (Cellepora) edax Busk, 1859.

Range.-Miocene-Recent.

The known species of this genus are as follows:

Hippoporidra (Cellepora) edax Busk, 1859, recent, fossil.

Hippoporidra (Lepralia) calcarea Smitt, 1873, recent, fossil.

Hippoporidra (Lepralia) maculata Ulrich and Bassler, 1904, Miocene.

Hippoporidra (Lepralia) parvula Canu and Bassler, 1923, Miocene.

This is a very natural and homogeneous genus. The zooecia are very small, and their study especially in the fossils, is troublesome and difficult. It is very difficult to differentiate the species.

Two good figures of the genotype have been published, that of Hincks, 1880, a recent specimen, and that of Busk, 1859, representing a specimen from the English Crag (Pliocene). Both are incomplete but as zoologists we will consider especially that of Hincks. Hippoporidra calcarea Smitt, 1872, differs in the absence of small frontal avicularia and in a somewhat larger apertural width. Hippoporidra maculata Ulrich and Bassler,1904, differs from $H$. edax in its large avicularium much less acuminate, in a somewhat larger apertural width, and in the presence of two areolar pores between the frontal costules. Finally Hippoporidra parvula Canu and Bassler, 1923, differs in its transverse aperture and in the presence of three or four small frontal avicularia.

All these species present curious phenomena of symbiosis.

The section which we gave in 1923 of Hippoporidra maculata proves that the genus belongs to the Celleporidae and not to the Escharellidae. 


\section{HIPPOPORIDRA EDAX Busk, 1859}

Plate 22, Figures 1-4

1873. Lepralia edax Smitt, Floridan Bryozoa. Kongl. Svenska VetenskapsAkademiens Handlingar, vol. 11. p. 63.

1889. Lepralia edax Jelly, A synomymic Catalogue of Marine Bryozoa, p. 126. (Bibliography.)

1923. Cellepora minuta CANU and BAssler, North American Later Tertiary and Quaternary Bryozoa. Bull. 125, U. S. National Museum, p. 182, pl. 25, figs. 10-13.

Measurements.-Apertural width $=0.06 \mathrm{~mm}$.

Structure.-Hincks, 1880, in introducing Hippoporidra calcarea Smitt, 1873, into synonymy with Hippoporidra edax Busk, 1859, made an error which rendered also problematical the synonymy of Miss Jelly, 1889. Smitt (p. 64) has indicated the difference in writing that the essential characters of the present species is the presence "of a median umbo just proximally of the zooecial aperture."

On our specimens the umbo is particularly constant on the salient (superficial) zooecia; it is less apparent on the immersed (deep) zooecia.

The apertural width is exactly that indicated by Smitt. $-0.0 .6 \mathrm{~mm}$. for the anter and 0.036 by $0.04 \mathrm{~mm}$. for the poster. The frontal is a granular pleurocyst surrounded by a single line of areolar pores separated by short costules (as in Hinck's figure). The ovicell has an identical structure, but the pleurocyst is incomplete and leaves a very fragile olocystal area. The interzooecial avicularium is rather rare; it always accompanies the groups of deep zooecia; its general form is lozenge-shaped. The small frontal avicularium is always placed on the line of areolar pores, but it is frequently wanting.

The fossil form which we describe in 1923 under the name of Cellepora minuta belongs to the present species. It presents, however, some slight differences; the umbo is not constant and between the costules there are sometimes, as in the fossil forms from the English Pliocene figured by Busk, two or three areolar pores. The anter is frequently almost as wide as the poster. The large interzooecial avicularium has a form very similar to that of Hippoporidra calcarea but with smaller dimensions.

Biology.-The superb specimen that we have studied measures $6 \mathrm{~cm}$. in length. It entirely covers a gastropod and emits two free and symmetrically arranged lateral branches. It is ovicelled (January 30,1885$)$. It is a case of symmetric symbiosis.

Smitt's specimen was only a small fragment of $4 \mathrm{~mm}$. in length, "a little compressed, pointed of pumicose consistence." This is the reason the small frontal avicularium can not be observed. 
We have always trouble in understanding the selective faculty of the larvae; the latter can not really choose their substratum of fixation; what is then the biochemical reaction which allows them to subsist only on shells of gastropods?

Occurrence.-Albaiross Station D. 2363 , east of Yucatan; $22^{\circ} 07^{\prime}$ $30^{\prime \prime}$ N.; $87^{\circ} 06^{\prime} 00^{\prime \prime}$ W.; 21 fms.; wh. r. coral.

Elbow Reef, Fla., 39 meters (Smitt).

Tertiary, Miocene: Wilmington, N. C., and Muldrows Mills, S. C. Pliocene: Waccamaw River, S. C.

Plesiotypes.-Cat. No. 7515, U.S.N.M.

HIPPOPORIDRA CALCAREA Smitt, 1873

Plate 22, Figures 5, 6; text Figure 30

1873. Lepralia calcarea SMITT, Floridan Bryozoa. Kongl. Svenska Vetenskaps Akademiens Handlingar, vol. 11, p. 63, pl. 11, figs. 220-223.

1914. Lepralia edax OsBurn, Bryozoa of the Tortugas Islands. Publication Carnegie Institution, No. 182, p. 212.

Siructure.-The apertural width is from 0.08 to $0.09 \mathrm{~mm}$.; there is no umbo on the frontal in agreement with Smitt's figure. The
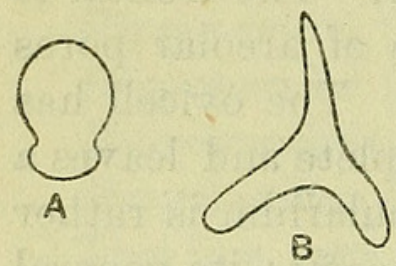

B zoarial avicularia are very small and inconsistent; their absence is much more frequent than their presence.

The operculum has a form very close to that of Hippoporina; we are not positively certain of the presence of muscular attachments. That of the ovicelled zooecia is much wider.

The area of the ovicell is not mem-

Fig. 30.-HipPoporidRA CALCAREA SMITT, 1873. A. ORDINARY OPERCULUM, $\times 85$. B. Mandible ot an interzooeciar AVICULARIUM, $\times 85$. C. OPERCULUM OF OVICELLED ZOOECIUM, $\times 85$ braneous as Osburn described it in 1914. It is formed by a very fragile olocyst.

The mandible is star-shaped with three more or less elongated branches.

Affinities.-The specific differences from Hippoporidra edax Busk, 1859 , are very slight. We do not yet know the chitinous appendages of the latter species, and we believe it prudent to keep the distinction made by Smitt. Too hasty conclusions as to synonymy are dangerous and lead the paleontologist to false stratigraphic conclusions.

Hippoporidra calcarea differs from $H$. maculata Ulrich and Bassler, 1904 , in which the frontal is without an umbo, in the more acuminate form of the large interzooecial avicularium without a salient beak.

Biology.-Our colonies encrust gastropods. They emit free radial branches in which the development is in relation to the general equilibrium of the entire colony. They appear to be able to float 
and to be easily transported by currents. We have found some other fragments coming certainly from more complete colonies.

Our living specimens were ovicelled in March and April.

Occurrence.-Fowey Light, 15 miles south of Miami, Fla., $40 \mathrm{fms}$.

Albatross Station D. 2387, Gulf of Mexico; $29^{\circ} 24^{\prime}$ $00^{\prime \prime}$ N.; $88^{\circ} 04^{\prime} 00^{\prime \prime}$ W.; 32 fms.; sand, gravel, broken shells.

Albatross Station D. 2640 , Straits of Florida; $25^{\circ} 05^{\prime}$ $00^{\prime \prime} \mathrm{N}$.; $80^{\circ} 15^{\prime} 00^{\prime \prime} \mathrm{W}$.; 56 fms.; coral sand.

Tortugas, 13-29 meters (Osburn); Florida, 79-127 meters (Smitt); Bermudas, shallow water (Verrill). Plesiotype-Cat. No. 7514 , U.S.N.M.

\section{Genus HIPPOTREMA Canu and Bassler, 1927}

The ovicell is hyperstomial and is not closed by the operculum. The zooecia are piled upon each other in disorder; their frontal is perforated by tremopores. The aperture is formed by a large orbicular anter and by a short poster separated by two cardelles. The operculum does not have lateral linear attachments.

Genotype.-Hippotrema (Lepralia) janthina Smitt, 1873.

Range.-Recent.

This is the $C$. janthina group of Waters of which we have published a text figure. ${ }^{10}$ The genus differs from Hippoporidra in the transformation of the pleurocyst into a tremocyst, in the different form of the poster, and in the absence of linear attachments to the operculum.

The only known species are:

Hippoirema (Lepralia) janthina Smitt, 1873, Florida.

Hippotrema (Lepralia) rotundora Norman, 1909, Madeira.

Waters, 1899, and Norman, 1909, are not in accord on the character of the second species.

\section{HIPPOTREMA JANTHINA Smitt, 1873}

1873. Lepralia janthina Smitr, Floridan Bryozoa. Kongl. Svenska Vetenskaps Akademiens, Handlingar, vol. 11, p. 63, pl. 11, figs. 224, 225.

1904. Lepralia janthina Osburn, Bryozoa of the Tortugas Islands. Publication Carnegie Institution, Washington, No. 182, p. 213. (No Waters, 1899) (according to Norman).

Measurements.--Width of aperture $=0.11$ (Smitt) to $0.12 \mathrm{~mm}$.

Structure.-The small avicularium is placed in the vicinity of the aperture; it is triangular and erected almost vertically. Contrary to the opinion of Osburn, there are interzooecial avicularia; they are long and thin; their presence is rather rare.

Biology.-Our living specimen encrusts Stylopoma spongites; it was in reproduction January 17, 1885.

${ }^{10}$ Canu and Bassler, 1920, p. 615, fig. 185. 
"The color is a deep blue black or violet" (Osburn). The margin of the aperture is usually of a little whitish tint in contrast with the black-bluish color of the zooecial wall (Smitt).

Occurrence.-Albatross Station D. 2320, north of Cuba; $23^{\circ} 01^{\prime} 39^{\prime \prime}$ N.; $82^{\circ} 18^{\prime} 48^{\prime \prime}$ W.; 130 fms.; fine coral.

Tortugas, 9 meters (Osburn); Florida, 21 meters (Smitt).

Plesiotype.-Cat. No. 7522, U.S.N.M.

\section{Genus HOLOPORELLA Waters, 1909}

\section{HOLOPORELLA ALBIROSTRIS Smitt, 1873}

Plate 22, Figures 10, 11; text Figure 31

1889. Cellepora albirostris JeLLy, A Synonymic Catalogue of Marine Bryozoa, p. 45.

1914. Holoporella albirostris OsBurn, Bryozoa of the Tortugas Islands. Publication Carnegie Institution, Washington, No. 182, p. 215.

1923. Holoporella albirostris $\mathrm{C}_{\mathrm{ANU}}$ and BAssLer, North American Later

Tertiary and Quaternary Bryozoa. Bull. 125, United States

National Museum, p. 174, pl. 7, figs. 9-14, pl. 32, figs. 6-10.

Measurements.-Diameter of the apertura, $0.14 \mathrm{~mm}$.

Structure.-We have little to add to the natural history of this rather common species. The deep interzooecial avicularia are thin

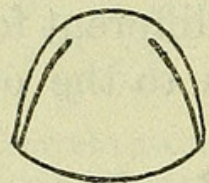

A

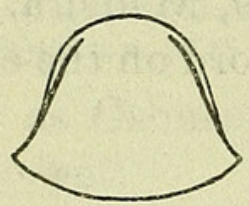

C

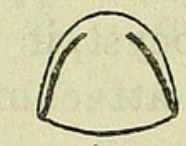

B

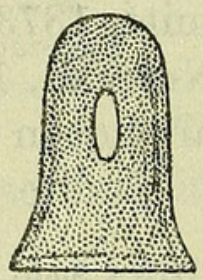

E

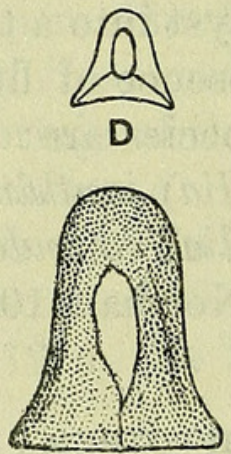

$F$

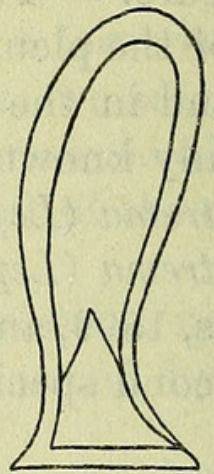

G

Fig. 31.-HOLOPORELla ALbIROSTRIS SMItT, 1873. A, B. TWO OPERCULA, $\times 85$, SHOWINg Variations. $C$. OPERCUlum OF a superficial zooecium. D. ManDIBLE OF AN ORAL AVICULARIUM. $E, F$. TWO MANDIBLES OF THE INTERzooecial avicularia showing variations of the LUCIDA. G. Large MANDIBLE

and long. The superficial interzooecial avicularia appear as large salient tubes as broad as the zooecia. Our figure represents an ensemble of well-preserved zooecia and superficial avicularia. It is easy to understand that such a spinous and fragile structure is easily broken and that the determination of fossil specimens presents great difficulties.

The operculum is very thin, quite transparent, and its preparation is very delicate. Nevertheless we believe that the figures of Busk, 
1885 , are not altogether exact. We have distinctly recognized the two linear lateral attachments common to Holoporella but they are little removed from the border. Furthermore, the two lamellae which habitually constitute the operculum glide very easily on one another and it seems to us that the small lateral sinuosities figured by Busk have no other origin than irregular gliding in the preparations.

The interzooecial avicularia have mandibles more rigid and more easy to prepare. Our mandibles are very close to those of Busk; the central lucida is quite variable in form and in position.

On the interior face of the free colonies the zooecia are arranged in longitudinal bifurcated rows.

Biology.- "It is readily recognizable by its grayish-brown color with blackish-brown opercula in the zooecial and avicularian apertures against which the calcareous white projecting rostra show it." (Smitt.) Except in the youngest stages, the colony has a dark grayish or blackish color against which the white spines stand out in sharp contrast." (Osburn.)

Our colonies are generally free and tubular. They probably encrust thin algae. Sometimes encrusting shells and Petralia. Moreover, the species has been observed on corals and even on sponges. This species has been observed only in little depths of water. Its geographic distribution is great.

Occurrence.-Albatross Station D. 2405, Gulf of Mexico; $28^{\circ} 45^{\prime}$ $00^{\prime \prime} \mathrm{N}$.; $85^{\circ} 02^{\prime} 00^{\prime \prime} \mathrm{W}$.; $30 \mathrm{fms}$.; gray sand, broken coral.

Albatross Station D. 2639, Straits of Florida; $25^{\circ} 04^{\prime}$ $50^{\prime \prime} \mathrm{N}$.; $80^{\circ} 15^{\prime} 10^{\prime \prime} \mathrm{W}$.; $56 \mathrm{fms}$.; coral sand.

Tortugas, low water, 24 meters (Osburn); Florida, 41-56 meters (Smitt).

Geographic distribution.-Indian Ocean: Heard Island, 121 meters. Pacific: Shark Islands, Port Jackson, 13 meters; and Port Philips Heads, Australia.

Geologic distribution.-Miocene of Australia (Waters); Pliocene of New Zealand (Waters); Oligocene of Anguilla; Miocene of Jamaica; Pliocene of Florida.

Plesiotypes.-Cat. No. 7527, U.S.N.M.

HOLOPORELLA MAG NIFICA Osburn, 1914

Plate 24, Figures 7, 8; text Figure 32

1914. Holoporella magnifica OsBuRn, Bryozoa from the Tortugas Islands. Publication Carnegie Institution, Washington, No. 182, p. 216, figs, $22,23$.

Measurements.-Aperture $\left\{\begin{array}{l}h a=0.24-0.26 \mathrm{~mm} \\ l a=0.28-0.30 \mathrm{~mm} .\end{array}\right.$ 
Structure.-Osburn did not give the chitinous appendages, so we have prepared them. The operculum bears laterally two very thick sclerites a little attenuated in the distal portion. The tentacular sheath is attached by two pairs of very thick muscles. The mandibles of the oral avicularia are semielliptical and strongly chitinized in their distal portion. The mandibles of the large interzooecial avicularia are very large, more or less rounded or somewhat acuminated. The muscular bundles are attached to them.

One of our colonies measures more than 20 square centimeters. It is tinted with brown.
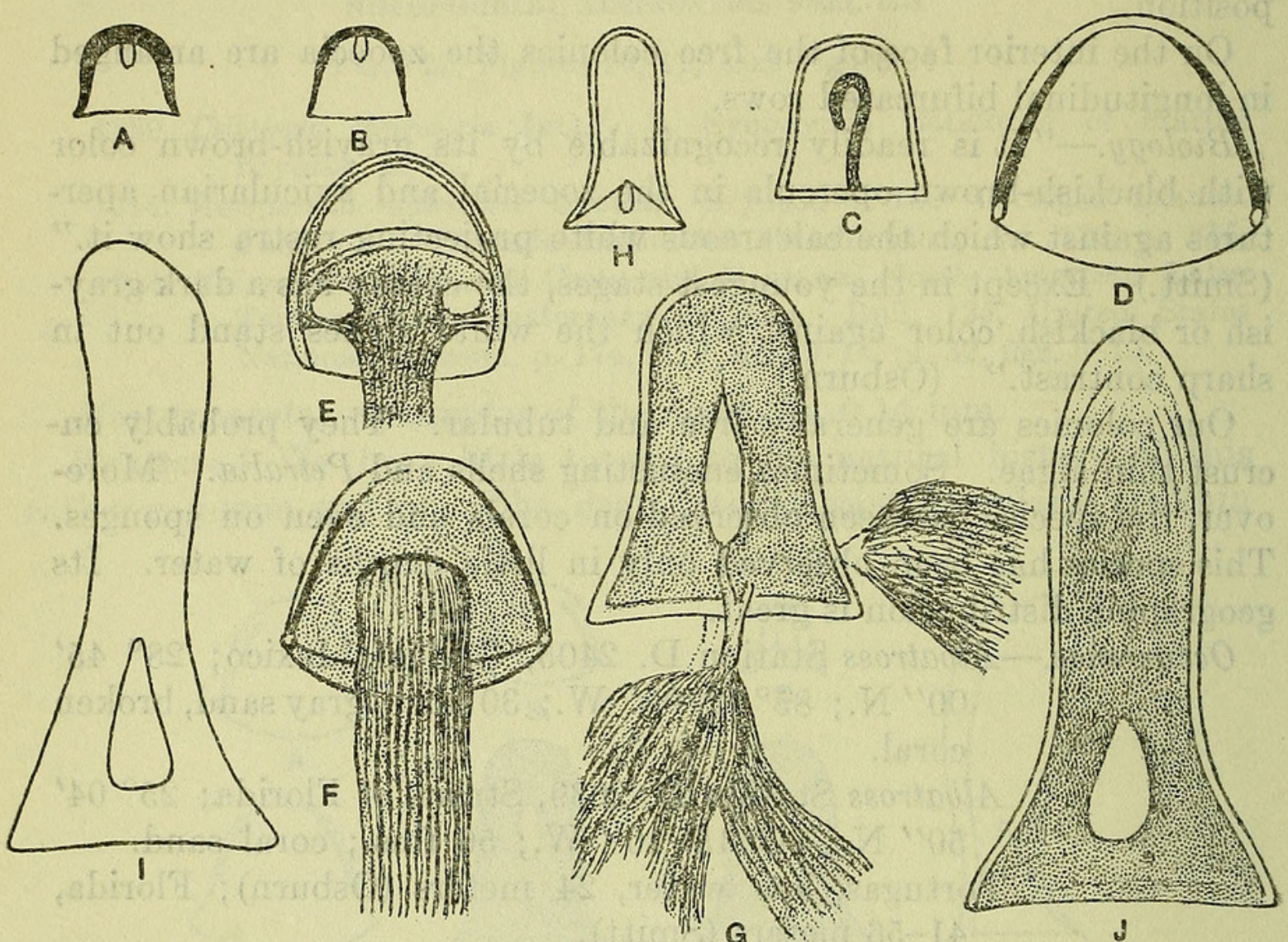

s

Fig. 32.-Holoporella magnifica Osburn, 1914. $A, B$. Mandible of the small zooecial avicularia, $\times$ 85. $C$. AN ordinary avicularian mandible. $D$. Isolated operculum. $\times 85 . E$. Operculum, $\times 85$, with attached tentacular sheath. $F$. Tentacular sheath attached to OPERCULUM, $\times 85$. $G$. MANDIBLE OF AN INTERZOOECIAL AVICULARIUM WITH ITS TWO PAIRS OF ELEVATOR AND OCCLUSOR MUSCLES GROUPED IN SUPERPOSED BUNDLES. $H$. A SMALL AVICULARIUM, $X$ 85. $I, J$. MaNdibles of large interzooecial avicularia, $\times 85$

Occurrence.-Albatross Station D. 2363, east of Yucatan; $22^{\circ} 07$ $30^{\prime \prime}$ N.; $87^{\circ} 06^{\prime} 00^{\prime \prime}$ W.; 21 fms.; white rock coral. Albatross Station D. 2405, Gulf of Mexico; $28^{\circ} 45^{\prime}$ $00^{\prime \prime}$ N.; $85^{\circ} 02^{\prime} 00^{\prime \prime}$ W.; 30 fms.; gray sand, broken coral.

Tortugas, 16 meters; and Biscayne Key, Florida (Osburn).

Plesiotypes.-Cat. No. 75265, U.S.N.M. 


\section{HOLOPORELLA TURRITA Smitt, 1873}

Text Figures $33 c$, $d$

1873. Lepralia turrita Smiтt, Floridan Bryozoa. Kongl. Svenska Vetenskaps Akademiens, Handlingar, vol. 11, p. 65, pl. 5, figs. 226-228.

1881. Cellepora turrita Ridley, Proc. Zoological Society, London, p. 55.

1890. Lepralia turrita Kirkpatrick, Hydrozoa and Polyzoa from the China Sea. Annals and Magazine of Natural History, ser. 6, vol. 5, p. 16.

1914. Holoporella turrita OsBurn, Bryozoa of the Tortugas Islands. Publication Carnegie Institution, Washington, No. 182, p. 217.

1923. Holoporella turrita CANU and Bassler, North American Later Tertiary and Quaternary Bryozoa. Bull. 125, U. S. National Museum, p. 179 , pl. 46 , fig. 1 .

Measurements.-Aperture $\left\{\begin{array}{l}h a=0.14 .-0.18 . \mathrm{mm} . \\ l a=0.18 \mathrm{~mm} .\end{array}\right.$

Structure.-There are two sorts of opercula. The transverse ones appear to correspond to deep zooecia and the elongated ones to super-

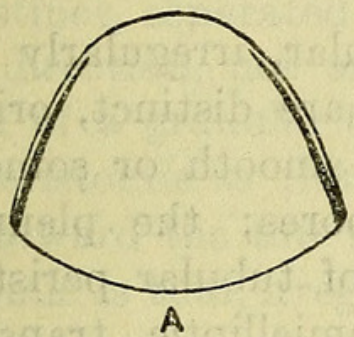

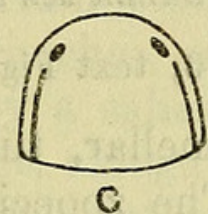

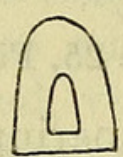

E

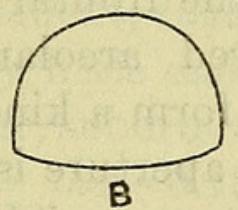

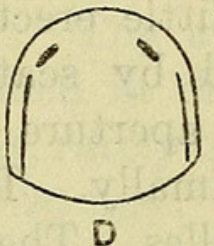

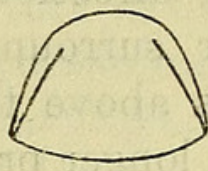

G

Fig. 33.-Opercula, $\times$ 85. A. Holoporella tubulosa, new species. B. Ho oporella subalba, NEW species. $C, D$. Holoporella turRita SMitt, 1873. $E-G$. Holoporella vagans Busk, 1888. $E$. Mandible. $F, G$. Opercula

ficial zooecia. We have made the same observation in spocimens from the Philippine Islands. Our specimens do not have the interzooecial avicularia figured by Smitt and which we have observed in the Philippine examples. Their presence appears to be in relationship with the tranquility of the waters.

Variations.- The number and the dimensions of the stout spines are alone variable; there are generally four or five on the specimens from the Gulf of Mexico and from two to six on the Philippine specimens. The fossil specimen from the Pleistocene of Panama is very vigorous; its apertural width is $0.20 \mathrm{~mm}$. In spite of the large number of specimens observed, the ovicell is not yet known. ${ }^{11}$

Biology. - "Color in life bright pink to brick red. The younger zooecia are separated by delicate, raised, white walls which are very conspicuous against the red color of the colony. The white points of the blunt spines are also strongly contrasted with the ground color." (Osburn.) 
The colonies encrust corals, nullipores, sponges, and more rarely shells. The species is more abundant in shallow waters. The richness of ornamentation is greater in calm waters. It is limited to the equatorial zone.

Occurrence.-Fowey Light, 15 miles south of Miami, Fla., $40 \mathrm{fms}$. Albatross Station D. 2319, north of Cuba; $23^{\circ} 19^{\prime}$ $37^{\prime \prime} \mathrm{N}$.; $82^{\circ} 20^{\prime} 06^{\prime \prime} \mathrm{W}$.; $143 \mathrm{fms}$.; gray coral. Albatross Station D. 2365 , east of Yucatan; $22^{\circ} 18^{\prime}$ $00^{\prime \prime} \mathrm{N}$.; $87^{\circ} 04^{\prime} 00^{\prime \prime} \mathrm{W}$.; $24 \mathrm{fms}$.; white rock coral. Florida, 44-71 meters (Smitt); Tortugas, 19-24 meters (Osburn).

Geographic distribution.-China Sea, Tizard Reef, 43 meters; Philippines.

Geologic distribution.-Pleistocene of Panama (Canu and Bassler). HOLOPORELLA SUBALBA new species

Plate 25, Figures 1-6; text Figure $33 b$

Description.-The zoarium is lamellar, tubular, irregularly bifurcated, little thickened, whitish. The zooecia are distinct, oriented in every direction, little erect; the frontal is smooth or somewhat granular surrounded by scattered areolar pores; the pleurocyst develops above the aperture to form a kind of tubular peristomie, oblique, longer proximally. The aperture is semielliptic, transverse, without visible cardelles. The interzooecial avicularia are irregularly developed but always somewhat spatulated. The ovicell is opened wide above the aperture.

$$
\text { Measurements.-Aperture }\left\{\begin{array}{l}
h a=0.12-0.15 \mathrm{~mm} . \\
l a=0.14-0.17 \mathrm{~mm} .
\end{array}\right.
$$

Variations.-The tubular zoarial form is little explicable, for we have not a single specimen with an alga as its substratum. Some specimens encrust serpulae and are plurilamellar.

On the colonies there are always some places where the cells are more erect. The deep zooecia are visible only through their peristomie and their peristomice.

This species is very well characterized by its pleurocystal, smooth and oblique peristomie, at the base of which there are always some areolar pores.

Biology.-The biology of the Cellepores is very difficult to understand, for, irregularity being the rule, it is impossible to explain the reason for the innumerable variations.

Variations.-It is necessary to note some general observations. The interior of the tubes is always clean and does not contain a single parasite even in the waters where the larvae of the latter are abundant. One of our specimens is very significant; it is juxtaposed to a colony of Petraliella bisinuata, and although the interior face of 
Petraliella is occupied by several parasitic colonies of Smittina and of Gemellipora, the inferior face and interior of the Holoporella contains absolutely nothing.

The zoarial development is very rapid; one of our colonies completely suppressed a serpula on which the larva was fixed.

Occurrence.-Albatross Station D. 2362, east of Yucatan; $22^{\circ} 08^{\prime}$ $30^{\prime \prime}$ N.; $86^{\circ} 53^{\prime} 30^{\prime \prime}$ W.; 25 fms.; coral sand.

Albatross Station D. 2363, east of Yucatan; $22^{\circ} 07^{\prime}$ $30^{\prime \prime} \mathrm{N}$.; $87^{\circ} 06^{\prime} 00^{\prime \prime} \mathrm{W}$.; $21 \mathrm{fms}$.; white rock coral. Albatross Station D. 2365, east of Yucatan; $22^{\circ} 18^{\prime}$ $00^{\prime \prime}$ N.; $87^{\circ} 04^{\prime} 00^{\prime \prime}$ W.; $24 \mathrm{fms}$; ; white rock coral.

Cotypes.-Cat. Nos. 7528, 7529, U.S.N.M.

HOLOPORELLA (?) TUBULOSA, new species

Plate 24, Figures 1-6; text Figure $33 a$

Description.-The zoarium creeps over Serpulae and emits free cylindrical bifurcated branches, sometimes adjacent. The zooecia are distinct, separated by a salient thread, very large, oriented in every direction, not erect, elongated, irregular; the frontal is flat, formed of a granular tremocyst and of large expanded tremopores. The peristomie is thin, salient, tubular. The aperture is oval, the point toward the top very little embedded in the peristomie. The peristomie is thin, irregular, suborbicular, rarely indented proximally.

Measurements.-Aperture $\left\{\begin{array}{l}h a=0.18-0.20 \mathrm{~mm} \\ l a=0.15-0.17 \mathrm{~mm} .\end{array}\right.$

$$
\text { Zooecia }\left\{\begin{array}{l}
L z=1.20 \mathrm{~mm} . \\
l_{z}=0.75 \mathrm{~mm} .
\end{array}\right.
$$

Structure.-Our micrometric measurements were taken on the most characteristic zooecia, but their form is generally indefinite and their dimensions variable.

The operculum is transverse, although the aperture is a little elongated. Its form is that of Holoporella; the linear attachments may be confused with the lateral borders.

Affinities.-This is a very divergent type in the genus Holoporella, for the cells are not accumulated. The long smooth peristomie approaches very much Coleopora, but the absence of the band around the operculum does not authorize the classification in this genus.

The ovicell is not known. A single specimen from each locality has been found. The specimen from Habana was free.

Occurrence.-Albatross Station D. 2160, off Habana, Cuba; $23^{\circ} 10^{\prime}$ $31^{\prime \prime} \mathrm{N}$.; $82^{\circ} 20^{\prime} 37^{\prime \prime} \mathrm{W}$.; $167 \mathrm{fms}$; coral.

Albatross Station D. 2319, north of Cuba; $23^{\circ} 10^{\prime} 37^{\prime \prime}$

N.; $82^{\circ} 20^{\prime} 06^{\prime \prime} \mathrm{W}$.; 143 fms.; gray coral.

Albatross Station D. 2405, Gulf of Mexico; $28^{\circ} 45^{\prime}$ $00^{\prime \prime} \mathrm{N}$.; $85^{\circ} 02^{\prime} 00^{\prime \prime} \mathrm{W}$.; $30 \mathrm{fms}$.

Cotypes.-Cat. No. 7532, U.S.N.M. 
HOLOPORELLA VAGANS Busk, 1885

Plate 25, Figures 7-13; text Figure $33 e-g$

1885. Cellepora vagans Busk, Polyzoa of Challenger. Report Results Voyage Challenger, vol. 10 , pt. 30 , p. 198 , pl. 29, fig. 10; pl. 35, fig.11.

Measurements.-Aperture $\left\{\begin{array}{l}h a=0.14-0.16 \mathrm{~mm} . \\ l a=0.16-0.18 \mathrm{~mm} .\end{array}\right.$

Length of avicularia $=0.30-0.50 \mathrm{~mm}$.

Variations.-The characters of our specimens are in perfect accord with those Busk has given for his Cellepora vagans. The oral sinus is very small although the rimule of the operculum is very large The zooecia are surrounded by areolar pores. The small oral avicuarium has a very salient beak. The marginal or ancestrular cells are oriented. Finally the interzooecial avicularia are long, rather thin with generally a linear mandible.

Busk gave only a small figure and spoke little of the variations. Here the small specimens are orbicular. The largest are unilamellar and free, or perhaps they form small rods, increasing cylindrically without base of fixation. The interzooecial avicularia are a little enlarged at their beak and their mandible is somewhat spatulate.

On the massive and tuberose colonies the tuberosities are formed by groups of large zooecia. Between these tuberosities there are groups of small zooecia in which the orifice measures only 0.10 by $0.14 \mathrm{~mm}$.

None of our specimens were ovicelled. The operculum does not correspond to the form of the aperture. In spite of the apertural proximal sinus, the operculum shows the essential characters of Holoporella. In view of this anomaly, we have made many preparations of specimens from different localities and all the opercula had the characteristic form of Holoporella with the two lateral bands.

Affinities.-In the form of the interzooecial avicularia this species is very close to Holoporella albirostris Smitt, 1873. It differs from it in the presence of a small proximal sinus with aperture and in the absence of a large avicularian umbo.

Biology.-The colonies have a beautiful flesh color. The larvæ fix themselves on small grains of solidified mud. The young colonies form small disks in which the maximum dimension is $10 \mathrm{~mm}$. The older and larger colonies have forms incompatible with their development on the sea bottom. It is presumed that they escape from the bottom and are able to float with a certain ease. The absence of a base of fixation confirms this hypothesis. This phenomenon is not limited to the present species, but it can be observed on a very large number of massive and free species. It is necessary then to conclude that all the Cellepores have been floating colonies and that this is the principal cause for their irregular development. Their extreme lightness in dry condition is well known. 
We have not observed parasites on the inferior face of our lamellar specimens.

Occurrence.-Fowey Light, 15 miles south of Miami, Fla.; $40 \mathrm{fms}$. Albatross Station D. 2639, Straits of Florida; $25^{\circ} 04^{\prime}$ $50^{\prime \prime} \mathrm{N}$.; $80^{\circ} 15^{\prime} 10^{\prime \prime} \mathrm{W}$.; $56 \mathrm{fms}$; coral sand.

Geographic disiribution.-Pacific: Honolulu, Sandwich Islands, 32-64 meters. Indian Ocean: Crozet Island, 340 meters.

Plesiotypes.-Cat. Nos. 7530, 7531, U.S.N.M.

\section{Genus SCHISMOPORA MacGillivray, 1888}

SCHISMOPORA DICHOTOMA Hincks, 1864

Plate 22, Figures 7-9; text Figure 34

1914. Cellepora dichotoma OsBurn, Bryozoa of the Tortugas Islands. Publication Carnegie Institution, Washington, No. 182, p. 214.

1880. Cellepora dichotoma JELLY, A synonymic Catalogue of Marine Bryozoa, p. 51 (Bibliography.)

Measurements.-Aperture $\left\{\begin{array}{l}h a=0.12 \mathrm{~mm} . \\ l a=0.09-0.10 \mathrm{~mm} \text {. }\end{array}\right.$

Variations.-This is a species well known in the Temperate Zone and its presence in the eastern Atlantic has been noted from Norway to the Azores Islands. In the Western Atlantic it undergoes notable variations. Already at Beaufort, N. C., the zooecia are much shorter, less oriented, and the colonies have no more the vigor of the British specimens. In the Gulf of Mexico, as our figures show, as well as those of Smitt, 1873 (C. avicularis, p. 53), the zooecia are short and very erect like those of more typical Cellepores.
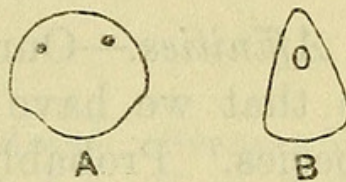

FIG. 34. - $\mathrm{S} \mathrm{CHIZMOPORA}$ DichoTOMA HiNCKs, 1864. O PERCULUM AND MANDIBLE, $\times 85$ The colonies are more constantly arborescent and sometimes are lamellose. Finally the apertural dimensions are somewhat divergent. The operculum has a form identical with that Nordgaard figured in $1903,{ }^{12}$ but it is smaller and contains two muscular attachments distant from the border. Certainly the specimens from the Gulf of Mexico belong to a variety distinct from the northern type.

Our specimens from the Pliocene of Panama are free, cylindrical, bifurcated; the zooecia and the avicularia very closely resemble the figure of Smitt, 1873 (C. avicularis); the width of the aperture $(0.10 \mathrm{~mm}$.) is almost that indicated by Smitt $(0.09 \mathrm{~mm}$.). These specimens, like the recent specimens from the Gulf of Mexico, scarcely resemble Cellepora dichotoma of the northern seas, of which we have very fine specimens; they are far removed also from the variety discovered at Beaufort by Osburn. We give two photographs, for Hincks's synonymy seems premature to us.

12 See Canu and Bassler, 1920 p. 599, fig. 178. 
Occurrence.-Pliocene: Minnitimmi Creek, Bocas Island, Almirante Bay, Panama. Albatross Station D. 2405, Gulf of Mexico.

Plesioiypes.-Cat. Nos. 7588, 70855, U.S.N.M.

\section{Genus CELLEPORA · Linnaeus, 1767}

CELLEPORA MINUTIPOROSA new species

Plate 28, Figure 1

Description.-The zoarium encrusts corals. The zooecia are distinct, large, poorly oriented, little erect, noncumulate. The frontal is convex and covered with a large number of very small pores. The apertura is subcircular and bears a very broad, round rimule. The oral avicularium is triangular, ascending and adjacent to one side of the apertural rimule. The ovicell is recumbent, relatively small, not closed by the operculum. The interzooecial avicularium is large with spathulate mandible; there are other small avicularia with semicircular mandibles.

$$
\begin{aligned}
\text { Measurements.-Apertura }\left\{\begin{array}{l}
h a=? \\
l a=0.20 \mathrm{~mm} .
\end{array}\right. \\
\text { Recumbent zooecia }\left\{\begin{array}{l}
L z=1.40 \mathrm{~mm} . \\
l z=0.75-1.10 \mathrm{~mm} .
\end{array}\right.
\end{aligned}
$$

Affinities.-Our specimens were dead and without chitinous organs, so that we have not been able to make a complete study of the species. Probably a special genus will be necessary in order to admit species with such structure and in which the cells are not heaped on top of one another.

Occurrence.-Albatross Station D. 2662, Atlantic; $29^{\circ} 24^{\prime} 30^{\prime \prime}$ N.; $79^{\circ} 43^{\prime}$ W.; 434 fms.; gray sand and broken shells.

Holotype.-Cat. No. 7474, U.S.N.M.

\section{Family LIRIOZOIDAE Levinsen, 1909}

\section{Genus PASYTHEA Lamouroux, 1812 (GEMELLIPORA Smitt, 1873, part)}

"Zooecium in the erect portion pinnate. Stem at first a double calcareous tube, then a succession of geminate zooecia of which two pairs constitute an internode, from the side of which equidistant, opposite pinnae, also composed of geminate zooecia, are given off at right angles. Zooecia geminate, closely connate, subcompressed, the oral portion subtubular and twisted round to opposite faces, front and back, in each pair. Surface smooth, entire, with a row of four to six punctae on each side and a few on the front. Peristome slightly thickened." (Busk, 1874.)

Genotype.-Cellaria iulipifera Ellis and Solander, 1786.

History.-The names Pasythea Lamouroux, 1812, and Liriozoa Lamarck, 1812, have been applied to the same species, Cellaria tulip- 
ifera Ellis and Solander, 1786. Pasythea has been chosen by Busk, 1884 , because of its priority. Smitt, 1873 , discovered a similar species eburnea but placed it in his new genus Gemellipora, making it the genotype. ${ }^{13}$ Waters, 1899, recognized Smitt's error and classed G. eburnea in Pasythea. In 1904 he retained the term Gemellipora with Gemellipora glabra Smitt, 1873, for the type, which MacGillivray, 1895, and Maplestone, 1901, had already done before him.

Levinsen, 1909, for these two species alone formed a distinct family Liriozoidae and two genera Gemellipora Smitt, 1873 (for G. eburnea), and Liriozoa Lamarck, 1812 (for L.tulipifera). The names are chosen in perfect accord with the rules of nomenclature. The characters observed by Levinsen in order to separate the two genera are clearly zoarial; the cells are arranged by threes in Liriozoa and by pairs in Gemellipora. We do not recognize this classification because the number of species is not sufficient and finally because the zooecial grouping does not appear to correspond to clearly differentiated functions. We now follow the simpler classification of Waters and later if the studies on the larvae of the two species, of their ovicells, of their anatomical characters, confirm the ideas of Levinsen we will be the first to admit it.

\section{PASYTHEA EBURNEA Smitt, 1873}

\section{Plate 8, Figures 11, 12}

1873. Gemellipora eburnea Smitr, Floridan Bryozoa. Kongl. Svenska Vetenskaps-Akademiens Handlingar vol. 11 , No. 4 , p. 35 , pl. 7 , figs. 152-156 (not pl. 35, pl. 9, figs. 177, 178).

1885. Pasythea eburnea Busk, Polyzoa collected by Challenger. Results Voyage Challenger, vol. 10, pt. 30, p. 5, pl. 34, fig. 1 .

1899. Pasythea eburnea Waters, Bryozoa from Madeira. Journal Royal Microscopical Society, p. 12, pl. 3, fig. 22 (opercula).

1909. Gemellipora eburnea Levinsen, Studies on Cheilostomatous Bryozoa, p. 313.

We have found only one fine specimen of this remarkable species and we have nothing to add to the excellent study of Busk, 1885. This author thought that the frontal pores are equivalent to the septules observed on the lateral walls of the zooecia in other cheilostomata. The small fragments of the frontal which we have photographed seem to verify this.

Occurrence.-Albatross Station D. 2331, north of Cuba; $23^{\circ} 10^{\prime}$ $31^{\prime \prime} \mathrm{N} . ; 82^{\circ} 19^{\prime} 55^{\prime \prime} \mathrm{W} . ; 114$ fms.; coral.

Florida, 275 meters (Smitt); Carribbean Sea, off Culebra Island, 631 meters (Busk); and off Sombrero Island, 729 meters (Busk).

13 "The name of the genus is chosen in reference to the colonial form of one of the Floridan species which may be named G. eburnea" (Smitt, 1872). 
Geographic distribution.-Eastern Atlantic Gulf of Gascony: (Waters); Madeira (Waters). Western Atlantic: Off Barra Grande, Brazil, 658 meters (Busk).

Plesiotypes.-Cat. No. 7566, U.S.N.M.

\section{Suborder Hexapogona Canu and Bassler, 1927}

\section{Family MAMILLOPORIDAE Canu and Bassler, 1927}

Following Waters, 1919, we have tried to place a little order in the classification of the Batopora-Mamillopora group. After the present studies on Mamillopora cupula and the studies that we have made on Philippine species we can state that the limits given by Waters to the genus Mamillopora are too great. In reality there are several genera perfectly distinguished by their opercula as well as their general structure.

The known genera of this family are as follows:

Mamillopora Smitt, 1873, Miocene-Recent.

Fedora Jullien, 1882-Recent.

Anoteropora Canu and Bassler, 1927, Pliocene-Recent.

Stenosipora Canu and Bassler, 1927, Eocene (Lutetian, Priabonian). Kionidella Koschinsky, 1885, Eocene (Lutetian) and Oligocene (Vicksburgian).

Prattia D'Archiac, 1847, Eocene (Auversian).

Ascosia Jullien, 1882-Recent.

\section{Genus MAMILLOPORA Smitt, 1873}

1873. Mamillopora Smitr, Floridan Bryozoa. Kongl. Svenska VetenskapsAkademiens Handlingar, vol. 11, p. 33.

The zoarium is cupuliform or conical and floating. The two faces are covered by mammillosities. The superior face contains only the aperture and its wide peristome. The aperture is subelliptical with two submedian cardelles. The peristome bears an elliptical or oval avicularium. The ovicelled zooecia are much larger.

Genotype.-Mamillopora cupula Smitt, 1873.

Range.-Miocene (Burdigalian)-Recent.

The other known species of the genus are as follows:

Mamillopora (Cupularia) bidenta Reuss, 1869 (according to Waters), Eocene (Priabonian).

Mamillopora tuberosa Canu and Bassler, 1919, Miocene (Bowden). Mamillopora cavernulosa, new name (=M. tuberosa Canu and Bassler, part), Miocene (Costa Rica).

\section{MAMILLOPORA TUBEROSA Canu and Bassler, 1919}

1919. Stichoporina tuberosa CANU and Bassler, Geology and Paleontology of the West Indies Bryozoa. Publication Carnegie Institution; Washington, No. 291, p. 98, pl. 7, figs. $1-8$ (not plates 1 and $6=$ Mamillopora cavernulosa and $M$. cupula). 
1923. Mamillopora tuberosa CANU and Bassler, North American Later Tertiary and Quaternary Bryozoa. Bull. 125, U. S. National Museum, p. 192, pl. 7, figs. 1-8 (not pl. 6, figs. 16-19).

This species differs from the genotype in its much larger and more constant mammillosities and in the presence of large hydrostatic cavities on the inner face.

Occurrence.-Miocene (Bowden); Bowden, Jamaica.

MAMULOPORA CAVERNULOSA, new name

1919. Stichoporina tuberosa $\mathrm{C}_{\mathrm{ANU}}$ and BAssler, Geology and Paleontology of the West Indies Bryozoa. Publication Carnegie Institution, Washington, No. 291, p. 98, pl. 1, figs. 20-23 (not pl. 7 and 6).

1919. Stichoporina tuberosa $\mathrm{C}_{\mathrm{ANU}}$ and Bassler, Geology and Paleontology of the Panama Canal Zone Bryozoa. Bull. 103, U. S. National Museum, p. 14, pl. 53, figs. 9-12.

This species differs from the genotype in its smaller dimensions, its finely punctated ovicell, and in the presence of numerous hydrostatic cavities on the inner face.

Occurrence.-Miocene (Gatun formation); Banana River, Costa Rica.

\section{MAMILLOPORA CUPULA Smitt, 1873}

Plate 26, Figures 3-13; text Figure 35

1873. Mamillopora cupula Smitt, Floridan Bryozoa. Kongl. Svenska Vetenskaps Akademiens Handlingar, vol. 11, p. 33, pl. 7, figs. 146, 147 $a-c$.

1919. Stichoporina tuberosa $\mathrm{CANU}_{\mathrm{ANU}}$ and BASsler (part), Geology and Paleontology of the West Indies Bryozoa. Publication Carnegie Institution, Washington, No. 291, p. 98, pl. 6, figs. 16-19 (not pl. 1 and $7=$ Mamillopora cavernulos $a$ and $M$. tuberosa).

1923. Mamillopora tuberosa $\mathrm{C}_{\mathrm{ANU}}$ and BAssler, North American Later Tertiary and Quaternary Bryozoa. Bull. 125, U. S. National Museum, p. 192 , pl. 6 , figs. $16-19$.

Measurements.-Aperture of nonovicelled $h a=0.14-0.20 \mathrm{~mm}$.

$$
\begin{gathered}
\text { zooecia } \quad\{l a=0.10-0.14 \mathrm{~mm} . \\
\text { Aperture of ovicelled zooecia }\left\{\begin{array}{l}
h a=0.20 \mathrm{~mm} . \\
l a=0.16 \mathrm{~mm} .
\end{array}\right.
\end{gathered}
$$

Structure.-The colonies have a discoidal or conical form. Their diameter is rather variable and measures $7 \mathrm{~mm}$. at the maximum. One of our conical specimens was dredged alive, and although dry it preserved its ectocyst and its opercula and was then perfectly inclosed. Plunging it in water, it floats with the point on top but completely immersed with the point touching the surface of the liquid. This is then a floating species like Conescharellina, but its position is inversed. Each colony is a small hydrostatic apparatus utilizing the principle of Archimedes as well as capillarity and adapting itself easily to various bathymetric exigencies of the oceanic depths. The cupuliform colonies float with much more difficulty. 
The seat of this hydrostatic apparatus is the interior face of the colonies. This is variable according to the form and size. The zooecia appear hexagonal, especially on specimens with the ectocyst; on others the character is little visible, and more often the cells are grouped in radial series. Each hexagon bears small, hollow, very irregular elevations and either a very small avicularium or a large avicularium identical with those of the superior cellular face. The large avicularia are arranged in widely spaced circular series. This character is specific and permits one to easily distinguish the species in the fossil forms in spite of the great irregularity of the elevations. We have already shown that in many other genera of bryozoa these elevations are really hydrostatic, and we have here still another proof. The physiologic function of the avicularium is here impossible to establish. The small specimens are deprived of them and certain species do not have them at all. The most reasonable hypothesis is that they are organs of defense against parasitism, for on the 50 specimens observed none of them bears parasitic colonies.

The longitudinal section shows that the cells are simple, erect hexagons with bases somewhat convex. This is a more simple architecture than that of Conescharellina and of Flabellopora, in which the bases are hexagonal pyramids.

The aperture is large, provided with two cardelles, and is placed at the center of the superior base. It is surrounded by a very thick peristome and covered also by the small very irregular tuberosities, characteristic of the genus. There is therefore a zooecial surface visible, contrary to that observed in other genera of the family. The peristome always bears to the right or to the left an elliptical avicularium more or less salient, the pivot of which is indicated by two lateral denticles. Smitt's figure is incorrect, for the avicularium appears here as interzooecial, although it is always peristomial and is not visible at the interior.

The ovicelled zooecia are wider than the adjacent zooecia; their aperture is also somewhat larger. The visible zooecial length is double, for they are formed of two cavities separated by a vertical partition. The proximal cavity is an ordinary zooecium, while the very large distal cavity is uniquely destined for the development of the embryos. The operculum closes the ovicell but it may fall and become supported on the separating partition, opening thus the ovicell for the escape of the larvae. This is really a kind of endozooecial ovicell, for the distal cavity occupies the place of another zooecium. This is another generic character that is not observed in other genera which have hyperstomial ovicells more or less embedded in the distal zooecia.

The operculum is much chitinized and bordered with a more or less broad and thick sclerite. It bears two broad linear attachments 
outlining the two lucidae and attached to the marginal sclerite. The two lucidae indicate the place of the cardelles. A transverse and thick sclerite placed below the axis of rotation serves probably as attachment for one of the walls of the compensatrix. The dimensions are not constant, for the aperture increases in size from the center to the circumference.

The ancestrula is frequently a zooecium larger than the adjacent zooecia; it is surrounded by six smaller zooecia, but their structure is identical and normal.

Biology.-Mamillopora cupula is a floating species. It has not been dredged in the high seas and appears to prefer the vicinity of the shores. The geometric regularity indicates that it can easily turn on its axis either to accomodate itself to the aquatic movements or to search for nourishment. It can at its pleasure rise or descend, but it is absolutely deprived of organs of motion. In our sections we have not discovered a substratum for the fixation of the larva, as in Conesch. arellina or Flabellopora. The larva is not fixed then (as in Lunulites) but it is transformed into a swim. ming larva. This is a very curious

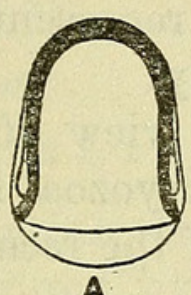

A

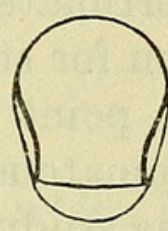

B

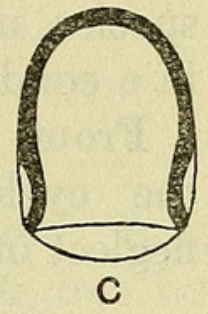

Fig. 35.-MAMillopora cupula Smitt, 1873. $A-C$. THREE FORMS OF OPERCULA, $\times 85$ phenomenon, indicating a larval structure very different from that of the other bryozoa. The discovery of the larva is therefore very desirable.

Occurrence.-Albatross Station D. 2405, Gulf of Mexico; $28^{\circ} 45^{\prime}$ $00^{\prime \prime} \mathrm{N}$.; $85^{\circ} 02^{\prime} 00^{\prime \prime} \mathrm{W}$.; $30 \mathrm{fms}$; gray sand, broken coral.

Fowey Light, 15 miles south of Miami, Fla.; $40 \mathrm{fms}$. Albatross Station D. 2411, Gulf of Mexico; $26^{\circ} 33^{\prime}$ $30^{\prime \prime} \mathrm{N}$.; $83^{\circ} 15^{\prime} 30^{\prime \prime} \mathrm{W}$.; $27 \mathrm{fms}$.; fine white sand, black specks.

Albatross Station D. 2639, Straits of Florida; $25^{\circ} 04^{\prime}$ $50^{\prime \prime}$ N.; $80^{\circ} 15^{\prime} 10^{\prime \prime}$ W.; 56 fms.; coral sand.

Florida, 48-110 meters (Smitt).

Miocene: Rio Cana, Santo Domingo.

Plesiotypes.-Cat. Nos. 7541, 7542, U.S.N.M.

\section{Family CHAPERIIDAE Jullien, 1888}

Genus CHAPERIA Jullien, 1888

CHAPERIA GALEATA Busk, 1852

1923. Chaperia galeata $\mathrm{CANU}_{\mathrm{AN}}$ and BASSLER, North American Later Tertiary and Quaternary Bryozoa. Bull. 125, United States National Museum, p. 52, pl. 34, figs. 8-10. (Bibliography, geologic and geographic distribution.)

Our specimens are ovicelled, ectocysted and ornamented with their distal spines. They are rare. 
Occurrence.-Albatross Station D. 2405, Gulf of Mexico; $28^{\circ} 45^{\prime}$ $00^{\prime \prime}$ N.; $85^{\circ} 02^{\prime} 00^{\prime \prime} \mathrm{W}$.; $30 \mathrm{fms}$.; gray sand, broken coral.

\section{Order CYCLOSTOMATA Busk}

The poverty of the Cyclostomatous fauna in the recent seas is more apparent than real. The great difficulty of determination causes authors to neglect the difficult, incomplete, or very rare specimens. In reality the species are rather abundant but they are rarely represented by a sufficient number of specimens for detailed study.

For the Gulf of Mexico region, Smitt cites 11 species and Osburn, 1914, 2 only, of which 1 is new for the area. We describe or cite 15 species in this work, 11 of which are new. The total is now 28 species. This number is not complete, for we have neglected seven species, unfortunately represented by unique specimens or those not in a condition for study.

From the point of view of the paleontologist, a knowledge of the cyclostomatous bryozoa is absolutely indespensable and the neglect of the study of the recent species is much to be regretted.

\section{Family CRISIIDAE Johnston, 1847}

\section{Genus CRISIA Lamouroux, 1816}

CRISIA DENTICULATA Lamarck, 1812

Plate 30 , Figure 4

1838. Crisia denticulata Milne Edwards, Mémoires sur les Crisies. Annales des Sciences Naturelles Zoologie, ser. 2, vol. 9, p. 9, pl. 7, fig. 1.

1873. Crisia eburnea Smiтt, Kongl. Svenska Vetenskaps-Akademiens Handlingar, vol. 10, p. 4, pl. 1, figs. 1 to 4 (not 5).

1891. Crisia denticulata Harmer, On the British species of Crisia. Quarterly Journal Microscopical Science, vol. 32, p. 129, pl. 12, figs. 1-3. (Bibliography.)

1914. Crisia denticulata OsBurn, Bryozoa of the Tortugas Islands. Publication Carnegie Institution No. 182, p. 185.

The segments collected are few in number but their determination does not appear doubtful. The restrictions made by Osburn are well founded. The joints are black.

Occurrence.-Albatross Station D. 2317 , north of Cuba; $24^{\circ} 25^{\prime}$ $45^{\prime \prime} \mathrm{N}$.; $81^{\circ} 46^{\prime} 45^{\prime \prime} \mathrm{W}$.; 45 fms.; coral.

Albatross Station D. 2405, Gulf of Mexico; $28^{\circ} 45^{\prime}$ $00^{\prime \prime} \mathrm{N}$.; $85^{\circ} 02^{\prime} 00^{\prime \prime} \mathrm{W}$.; $30 \mathrm{fms}$.; gray sand, broken coral.

Florida, 11-97 meters (Smitt); Tortugas, 16-24 meters (Osburn). 
CRISIA ELONGATA Milne Edwards, 1838

Plate 30, Figure 3

1838. Crisia elongata Milne Edwards, Mémoires sur les Crisies. Annales des Sciences Naturelles Zoologie, ser. 2, vol 9, p. 10, pl. 7, fig. 2.

This species is well characterized by the great length of the segments, which may bear 26 to 30 tubes. Our specimens are very similar to the figure of Milne Edwards, but their micrometric dimensions vary visibly from the dimensions given by Waters, 1914, for specimens from British East Africa. We have figured the ovicell.

Occurrence.-Albatross Station D. 2405, Gulf of Mexico; $28^{\circ} 45^{\prime}$ $00^{\prime \prime}$ N.; $85^{\circ} 02^{\prime} 00^{\prime \prime} \mathrm{W}$.; 30 fms.; gray sand, broken coral.

Pliocene: Minnitimmi Creek, Bocas Island, Almirante Bay, Panama.

Plesiotypes.-Cat. No. 7481, U.S.N.M.

CR1SIA species

Plate 30, Figures 1, 2

We have discovered a curious segment with white joints. It is close to a variety of $C$. denticulata figured by Hincks, 1880 , but its dimensions appear larger. We figure the specimen and believe that it belongs to a new species, although we are not able to give it a detailed description.

Occurrence.-Albatross Station D. 2405, Gulf of Mexico; $28^{\circ} 45^{\prime}$ $00^{\prime \prime} \mathrm{N}$.; $85^{\circ} 02^{\prime} 00^{\prime \prime} \mathrm{W}$.; $30 \mathrm{fms}$; gray sand, broken coral.

\section{Family DIASTOPORIDAE Gregory, 1899}

Forma PROBOSCINA Audouin, 1826

In the different Gulf of Mexico localities studied we have collected seven species of Siomatopora and Proboscina which are represented by such unique and incomplete specimens that their description would be doubtful and useless to science.

\section{PROBOSCINA ROBUSTA, new species}

Plate 30 , Figure 7

Description.-The zoarium encrusts sponges. It is formed of long biserial branches, straight or undulated; the angle of divergence is small. The tubes are short, striated transversely, terminated by a very salient peristomie. The peristome is thin and orbicular.

Measurements.-Diameter of orifice, $0.20 \mathrm{~mm}$.

Diameter of peristome, $0.24 \mathrm{~mm}$.

Distance of peristomes, $0.80 \mathrm{~mm}$.

Diameter of branches, $0.64 \mathrm{~mm}$. 
Affinities.-The figured specimen only has been found but it was interesting to us because of its great vigor. Proboscina parviangulata Canu and Bassler, 1920, can alone be compared with it but it differs from that species in its more closely spaced peristomes and in the occasional presence of paired tubes.

The branches enlarge before bifurcating and they bear three or four rows of tubes.

Occurrence.-Albatross Station D. 2319 , north of Cuba; $23^{\circ} 10^{\prime}$ $37^{\prime \prime} \mathrm{N}$.; $82^{\circ} 20^{\prime} 06^{\prime \prime} \mathrm{W}$.; 143 fms.; gray coral.

Holotype.-Cat. No. 7572, U.S.N.M.

\section{Family ONCOUSOECIIDAE Canu, 1918}

\section{Genus ONCOUSOECIA Canu, 1918}

ONCOUSOECIA ARCUATA, new species

Plate 31, Figure 2

Description.-The zoarium encrusts shells; the branches are long, somewhat arched, claviform, mono to triserial. The tubes are thin, rather long, little visible, striated transversely. The peristome is thin, orbicular, little salient. The ovicell is globular, as wide as the branches; the oeciostome is terminal, a little smaller than the peristome.

Measurements.-Diameter of orifice, $0.10 \mathrm{~mm}$.

Diameter of peristome, $0.12 \mathrm{~mm}$.

Distance of peristomes, $0.72 \mathrm{~mm}$.

Diameter of branches (at the extremity), $0.60 \mathrm{~mm}$.

This species is very well characterized by its globular ovicells.

Occurrence.-Albatross Station D. 2639, Straits of Florida; $25^{\circ} 04^{\prime}$ $50^{\prime \prime} \mathrm{N}$.; $80^{\circ} 15^{\prime} 10^{\prime \prime} \mathrm{W}$.; 56 fms.; coral sand.

Holotype.-Cat. No. 7564, U.S.N.M.

\section{Genus PERISTOMOECIA Canu and Bassler, 1920}

PERISTOMOECIA FLORIDANA, new species

Plate 31, Figures 6-9

Description.-The zoarium encrusts dead shells; the branches are formed of small successive palm-shaped areas and are dichotomous. The tubes are visible, cylindrical, striated transversely, terminated by a very long free and erect peristome. The peristome is thin, orbicular, or oval. The ovicell is orbicular, convex, with a small salient oeciostome at the center.

Measurements.-Diameter of orifice, $0.06 \mathrm{~mm}$.

Diameter of peristome and of tubes, $0.08-0.10 \mathrm{~mm}$.

Separation of peristomes, $0.50 \mathrm{~mm}$.

Distance of peristomes, $0.50 \mathrm{~mm}$.

Affinities.-All the Berenicea forms resemble each other, and when the micrometric dimensions are close their differentiation is very difficult. In order to separate them accurately it is necessary to. 
know the variations of the zoarial form, the ovicell and its deformations, and the protoecium which is almost always destroyed.

There are no recent species in which all these characters have been carefully studied and figured. Their comparison is therefore quite useless. Here the free peristome attains almost to $0.50 \mathrm{~mm}$. in length; it is very fragile and is broken on dead or dried specimens.

Occurrence.-Albatross Station D. 2639, Straits of Florida; $25^{\circ} 04^{\prime}$ $50^{\prime \prime}$ N.; $80^{\circ} 15^{\prime} 10^{\prime \prime}$ W.; 56 fms.; coral sand.

Cotypes.-Cat. No. 7567, U.S.N.M.

\section{Family PLAGIOECIIDAE Canu, 1918}

\section{Genus PLAGIOECIA Canu, 1918}

PLAGIOECIA DISPAR, new species

Plate 31, Figure 10

Description.-The zoarium is orbicular; it encrusts small dead shells. The tubes are distinct, separated by a furrow or by a thread, cylindrical with a little salient and very oblique peristome. The peristome is thin, orbicular, or oval. The ovicell is very long, quite convex, not marginal.

Measurements.-Diameter of orifice, $0.05 \mathrm{~mm}$.

Diameter of peristome, $0.07 \mathrm{~mm}$.

Distance of tubes, $0.44 \mathrm{~mm}$.

Separation of tubes, $0.30 \mathrm{~mm}$.

Affinities.-This species is well characterized by the subcentral place of its ovicell, contrary to the general rule. In the length of this ovicell, it approaches Diastopora lactea Calvet, 1903, but differs from it in the absence of concentric wrinkles on the colonies and in the somewhat smaller micrometric measurements.

Occurrence.-Albatross Station D. 2639, Straits of Florida; $25^{\circ} 04^{\prime}$ $50^{\prime \prime} \mathrm{N}$.; $80^{\circ} 15^{\prime} 10^{\prime \prime} \mathrm{W}$.; $56 \mathrm{fms}$.; coral sand.

Holotype.-Cat. No. 7571, U.S.N.M.

PLAGIOECIA SAR NIENSIS Norman, 1864

Plate 34 , Figure 10

1889. Diastopora sarniensis JELLY, A synonymic catalogue of Marine Bryozoa, p. 85. (Bibliography.)

1907. Diastopora sarniensis Calvet, Bryozoaires. Expedition scientifique Travaileur et Talisman, p. 415. (Bibliography.)

Our specimen encrusts a fragment of shell and is ovicelled. This is a cosmopolitan species.

Occurrence.-Pliocene: Minnitimmi Creek, Bocas Island, Almirante Bay, Panama.

Geographic distribution.-Eastern Atlantic: British Channel. Mediterranean and Adriatic. Pacific: Queen Charlotte Islands, Australian shores, China Sea.

Plesiotypes.-Cat. No. 70852, U.S.N.M. 
Genus ENTALOPHORA Lamouroux, 1821

ENTALOPHORA PROBOSCIDEOIDES Snitt, 1872

Plate 34, Figure 11

1872. Pustulopora proboscideoides Smitt, Floridan Bryozoa. Kongl. Svenska

Vetenskaps-Akademiems, vol. 10, p. 11, pl. 4, figs. 26, 27.

Affinities.- Smitt compared his species with a species of Gabb and Horn, 1862 (p. 170, pl. 21, fig. 60a), found in the Eocene of Alabama. The figure of the American authors represents a very small fragment, and it is very difficult to be certain of the identification, since we have not discovered an analogous specimen in our immense amount of material from Eocene and Miocene localities.

Our specimens are quite similar to the figures of Smitt.

Occurrence.-Recent: Florida, 110 meters (Smitt). Pliocene: Minnitimmi Creek, Bocas Island, Almirante Bay, Panama.

Plesiotypes.-Cat. No. 70839, U.S.N.M.

\section{Family MECYNOECIIDAE Canu, 1918}

Genus MECYNOECIA Canu, 1918

MECYNOECIA DEFLEXA Smitt, 1872

Plate 31, Figure 1

1872. Entalophora deflexa Smitt, Floridan Bryozoa. Kongl. Svenska Vetenskaps-Akademiens Handlingar, vol. 10, p. 11, pl. 5, figs. 28-30.

The synonymy of this species is in controversy, but as our materials are not sufficient we have abstained from making any criticism. Our specimens conform to Smitt's figures.

We have been rather fortunate to discover a base which we have figured. Up to the present the species appears restricted to America around Florida.

Occurrence.-Albatross Station D. 2405, Gulf of Mexico; $28^{\circ} 45^{\prime} 00^{\prime \prime}$ N.; $85^{\circ} 02^{\prime} 00^{\prime \prime} \mathrm{W}$.; $30 \mathrm{fms}$.; gray sand, broken coral. Albatross Station D. 2639, Straits of Florida; $25^{\circ} 04^{\prime}$ $50^{\prime \prime} \mathrm{N}$.; $80^{\circ} 15^{\prime} 10^{\prime \prime} \mathrm{W} . ; 56 \mathrm{fms}$.; coral sand.

Gulf of Mexico, Egmont Key, Florida; Florida, 26 meters (Smitt).

Plesiotypes.-Cat. No. 7553, U.S.N.M.

\section{Family DIAPEROECIIDAE Canu, 1918}

\section{Genus DIAPEROECIA Canu, 1918}

DIAPEROECIA RADICATA Kirkpatrick, 1888

Plate 31, Figures 3-5

1872. Idmonea milneana Sмiтt, Floridan Bryozoa. Kongl. Svenska Vetenskaps-Akademiens Handlingar, vol. 10, p. 8, pl. 3, figs. 14-17.

Variations.-Most of our specimens correspond well to Smitt's figures; the tubes, nonadjacent, are arranged in oblique rows to the 
number of three, but, as Smitt has already noted, there are only one or two tubes per row on certain small branches. Moreover, we found specimens having a larger number of tubes on the branches; they have a more idmoneiform aspect, although they never present true alternating fascicles.

In the two cases the ovicell is always the same. It belongs to the Diaperoecia type with central oeciostome. The latter is curved toward the base in a contrary direction to the peristome of the adjacent tubes. The tube which engenders the ovicell is always placed in the immediate vicinity of the median longitudinal axis of the branch.

Here the oeciostome is indeed specific, and we have not observed very important variations on our specimens. On the other idmoneiform species of this genus (Diaperoecia pulcherrima Kirkpatrick, $1890)$ its form is very different.

The decoration of the tubes is not as beautiful as in specimens from the Philippines where the specimens are highly ornamented. We attribute this phenomenon to the great calm of the waters of the Pacific, while in the vicinity of Florida the passage of the Gulf Stream profoundly modifies the fauna. The species was in reproduction March 15, 1885.

Occurrence.-Albatross Station D. 2405, Gulf of Mexico; $28^{\circ} 45^{\prime}$ $00^{\prime \prime} \mathrm{N}$.; $85^{\circ} 02^{\prime} 00^{\prime \prime} \mathrm{W}$.; 30 fms.; gray sand, broken coral.

Albatross Station D. 2639, Straits of Florida; $25^{\circ} 04^{\prime}$ $50^{\prime \prime} \mathrm{N}$.; $80^{\circ} 15^{\prime} 10^{\prime \prime} \mathrm{W}$.; $56 \mathrm{fms}$; coral sand.

Gulf of Mexico, Egmont Key, Fla. Florida, 19-97 meters (Smitt).

Plesiotypes.-Cat. No. 7488, U.S.N.M.

Genus DIPLOSOLEN Canu, 1918

DIPLOSOLEN OBELIUM Johnston, 1838

Plate 31, Figure 11

1889. Diastopora obelia JeLLY, A synonymic Catalogue of Marine Bryozoa, p. 83. (Bibliography.)

1896. Diastopora obelia Neviani, Briozoi Postpliocenici di Spilinga. Atti Accademia di Scienze Naturali in Catania, ser. 4, vol. 9, p. 60 。 (Bibliography.)

1901. Diastopora obelia Neviani, Bryozoi neogenici delle Calabrie. Palaeontographia Italica, vol. 6, p. 240. (Local bibliography.)

1905. Diastopora obelia Neviani, Briozoi fossili di Carrubare. Bollettino Societa Geologica Italiana, vol. 23, p. 551.

1907. Diastopora obelia Calvet, Bryozoaires. Expédition scientifique Travailleur et Talisman, p. 464. (Complementary bibliography.)

The study of the bibliography of this species will certainly give good biologic information. Its discovery to the south of North $58513-28-11$ 
America is very important. As it has not yet been discovered among the fossils, we must conclude that it arrived here only in the recent epoch. However, the genus Diplosolen is know since the Jacksonian.

Occurrence.-Albatross Station D. 2319 , north of Cuba; $23^{\circ} 10^{\prime}$ $37^{\prime \prime} \mathrm{N}$.; $82^{\circ} 20^{\prime} 06^{\prime \prime} \mathrm{W}$.; $143 \mathrm{fms}$.; gray coral.

Albatross Station D. 2321, north of Cuba; $23^{\circ} 10^{\prime}$ $54^{\prime \prime}$ N.; $82^{\circ} 18^{\prime} 00^{\prime \prime}$ W.; 230 fms.; fine gray sand.

Geologic distribution.-Helvetian of Touraine, France (Canu collection) Tortonian of Hungary (U. S. National Museum); Sicilian of Italy (Neviani). Pleistocene of Italy (Neviani, Sequenza).

Geographic distribution.-Northern Hemisphere, where it inhabits the principal seas; Spitzberg, Sea of Kara, Nova Zembla, Greenland, Jean Mayen (Gulf of St. Lawrence) Scandinavian, Danish and British coasts and English Channel, Gulf of Gascony, Grand Banks of Newfoundland.

Plesiotypes.-Cat. Nos. 7489, 7490, U.S.N.M.

\section{Genus CRISULIPORA Robertson, 1910}

\section{CRISULIPORA ORIENTALIS, new species}

Plate 29, Figures 3-8

Description.-The zoarium is attached to floating bodies; it is articulated and formed of claviform bi to tri furcate segments in which the noncellular face is plain or concave. The tubes are distinct, separated by a furrow, finely striated transversely by lines of punctations, terminated by a long, free, arched and erect peristome. The peristome is thin and orbicular.

Measurements.-Diameter of peristome, $0.14 \mathrm{~mm}$.

Maximum length of peristome, $0.56 \mathrm{~mm}$.

Distance of peristomes, $0.80 \mathrm{~mm}$.

Separation of peristomes, $0.72 \mathrm{~mm}$.

Maximum length of segments, $7.00 \mathrm{~mm}$.

Maximum width of segments, $3.00 \mathrm{~mm}$.

Affinities.-Like the other species of this genus, this species is attached to floating algae; the colonies are not bushy. They creep in the manner of Proboscina but remain free. The rounded substratum is the cause of the dorsal concavity of the segments. The species differs from Crisulipora occidentatis Robertson, 1910, in the concave form of the dorsal of the segments, in the flabellated segments, and in the smaller micrometric dimensions. It differs from Crisulipora flabellata Canu and Bassler, 1920, in its much larger and broader segments and in the greater length of the free peristomes.

The genus begins in the Vicksburgian of Alabama and we have described four species. The simultaneous presence on the western and eastern shores of the United States is proof of the ancient com- 
munication between the Pacific and the Atlantic and that the Isthmus of Panama is of relatively recent formation. The genus Crisulipora appears to be a genus purely American, for it has not yet been observed on the other continents.

Occurrence.-Gulf of Mexico, Egmont Key, Fla.

Cotypes.-Cat. No. 7837, U.S.N.M.

\section{Family HORNERIDAE Gregory, 1899}

\section{Genus HORNERA Lamouroux, 182I}

HORNERA GALEATA Smitt, 1872

1872. Hornera galeata Smits, Floridan Bryozoa. Kongl. Svenska Vetenskaps Akademiens Handlingar, vol. 10, p. 10, pl. 4, figs. 23-25.

Occurrence.-Albatross Station D. 2319 , north of Cuba; $23^{\circ} 10^{\prime}$ $37^{\prime \prime} \mathrm{N}$.; $82^{\circ} 20^{\prime} 06^{\prime \prime} \mathrm{W}$.; $143 \mathrm{fms}$.; gray coral.

Florida, 296 meters (Smitt).

\section{Family LICHENOPORIDAE Smitt, 1866}

\section{Genus LICHENOPORA Defrance, 1823}

LICHENOPORA RADIATA Audouin, 1826

Plate 29, Figures 1, 2

1889. Lichenopora radiata $\mathrm{JELLY}_{\mathrm{E}}$ A synomymic Catalogue of the Marine Bryozoa, p. 137.

1923. Lichenopora radiata $\mathrm{C}_{\mathrm{ANU}}$ and BASSle $\mathrm{R}$, North American Later Tertiary and Quaternary Bryozoa. Bull. 125, U. S. National Museum, p. 204, pl. 44, fig. 10. (Bibliography, geographic and geologic distribution.)

Our specimens are rare, but their discovery is important because it exemplifies the great vigor of the species. It is universal as far as the polar circle and its geologic distribution is considerable since the Miocene proving the great instability of the oceanic shores.

Occurrence.-Albatross Station D. 2319, north of Cuba; $23^{\circ} 10^{\prime} 37^{\prime \prime}$

$$
\mathrm{N} \text {; } 82^{\circ} 20^{\prime} 06^{\prime \prime} \mathrm{W} \text {; } 143 \text { fms.; gray coral. }
$$

Albatross Station D. 2334, north of Cuba; $23^{\circ} 10^{\prime} 42^{\prime \prime}$

N.; $82^{\circ} 18^{\prime} 24^{\prime \prime}$ W.; 67 fms.; white coral.

Plesiotypes.-Cat. No. 7539, U.S.N.M.

LICHENOPORA BUSKI? Harmer, 1915

Plate 29, Figure 9

For the bibliography and discussion, see our Philippine volume.

Variations.-The figured specimens show all the zooecial characters of Lichenopora buski Harmer, 1915. However, the colony is twice as large, with a considerably larger number of radial rows of tubes. As we have not discovered the ovicell, we have not judged it wise to consider it a new species.

Our specimen encrusted a colony of Stylopoma spongites; it was dead and deprived of an ectoeyst. 
Occurrence.-Albatross Station D. 2320, north of Cuba; $23^{\circ} 10^{\prime} 39^{\prime \prime}$ N.; $82^{\circ} 18^{\prime} 48^{\prime \prime}$ W.; 130 fms.; fine coral.

Plesiotype.-Cat. No. 7540, U.S.N.M.

\section{LICHENOPORA BUSKIANA, new name}

Plate 34, Figures 7, 8

1875. Discoporella californica Busk, Catalogue Marine Polyzoa British Museum, pt. 3, Cyclostomata, p. 32, pl. 30, fig. 5 .

In 1923 (p. 203) we noted that Lichenopora californica of Conrad, 1855 , and of Robertson, 1910, was neither the species of Busk, 1875, nor of D'Orbigny, 1852, and we preserved Conrad's name, D'Orbigny's specimen not having been figured yet. We now take the occasion to change Busk's species to Lichenopora buskiana, new name. Our determination is a little doubtful, for the specimen is incompletely developed and very small, but it has the characters cited by Busk in his diagnosis, "zoarium thick; fasciculi much raised and biserial; mouths of cells less than the cancelli." The veinules between the cancelli on the figure of Busk are here also quite visible.

It is interesting to discover in the Pliocene of Panama a species not observed in the Gulf of Mexico, but which lives in the Pacific. In addition to this one, we have already noted Callopora curvirostris Hincks, 1881, Tremopora radicifera Hincks, 1881, and Hippopodina feegensis Busk, 1884. The formation of the Isthmus of Panama seems, therefore, quite recent.

Occurrence.-Pliocene; Minnitimmi Creek, Bocas Island, Almirante Bay, northwest Panama.

Holotype.-Cat. No. 70847, U.S.N.M.

\section{Genus DOMOPORA D'Orbigny, 1847}

\section{DOMOPORA FLORIDANA, new species}

Plate 30, Figures 5, 6

The small specimen which we figure contains only two superposed colonies. The center is concave and occupied by large polygonal cancelli. The tubes are open on the circumference. They are adjacent and form little salient, indistinct, longitudinal lines separated by polygonal cancelli of the same diameter. This specimen was fixed on a nullipore. Our object in publishing this figure was to show the persistence in the recent seas of the zoarial form observed frequently in the ancient seas of the Cretaceous and Tertiary. We have discovered another species of Domopora in the Philippines. The extreme rarity of the material studied does not permit us, unfortunately, to make a scientific study of the ancient genus Domopora.

Occurrence.-Albatross Station D. 2405, Gulf of Mexico; $28^{\circ} 45^{\prime}$ $00^{\prime \prime}$ N.; $85^{\circ} 02^{\prime} 00^{\prime \prime}$ W.; 30 fms.; gray sand, broken coral.

Holotype-Cat. No. 7491, U.S.N.M. 
Family TUBULIPORIDAE Johnston, 1838

\section{Genus IDMONEA Lamouroux, 1821}

IDMONEA ATLANTICA Forbes, 1847

\section{Plate 34, Figure 9}

Small but well-preserved examples of this widespread species have been found in the Panama Pliocene deposits.

Occurrence.-Pliocene: Minnitimmi Creek, Bocas Island, Almirante Bay, Panama.

Plesiotypes.-Cat. No. 70845, U.S.N.M. 

PLA T ES 


\section{EXPLANATION OF PLATES}

\section{Plate 1}

FIG. 1. Aetea truncata Landsborough, 1852

Specimen incrusting a shell; $\times 20$.

Albatross Station D. 2405, Gulf of Mexico.

2. Aetea sica Couch, $1844 \ldots$

Creeping portion of zoarium; $\times 20$.

Albaiross Station D. 2672, Atlantic, east of Georgia.

3. Levinsenella brasiliensis Busk, 1884

A branch with ectocyst and ovicells preserved; $\times 20$.

Albatross Station D. 2117, Caribbean Sea.

4. Nitscheina membranacea Linnaeus, 1766

Specimen with ectocyst, deformed in drying; $\times 20$.

Albatross Station D. 2782, off Chili, South America.

5,6. Acanthodesia savarti Savigny-Audouin, 1826

5. Surface of zoarium, $\times 20$, showing the characteristic serrate denticle.

6. Tangential section illustrating structure of zooecial walls; $\times 85$.

Albatross Station D. 2405, Gulf of Mexico.

7-9. Cupuladria canariensis Busk, 1852

7. Young zoarium, $\times 20$, illustrating central zooecia.

8. Marginal zooecia; $\times 20$.

9. Inner face without ectocyst, showing the large pores; $\times 20$.

Albatross Station D. 2405, Gulf of Mexico

166 

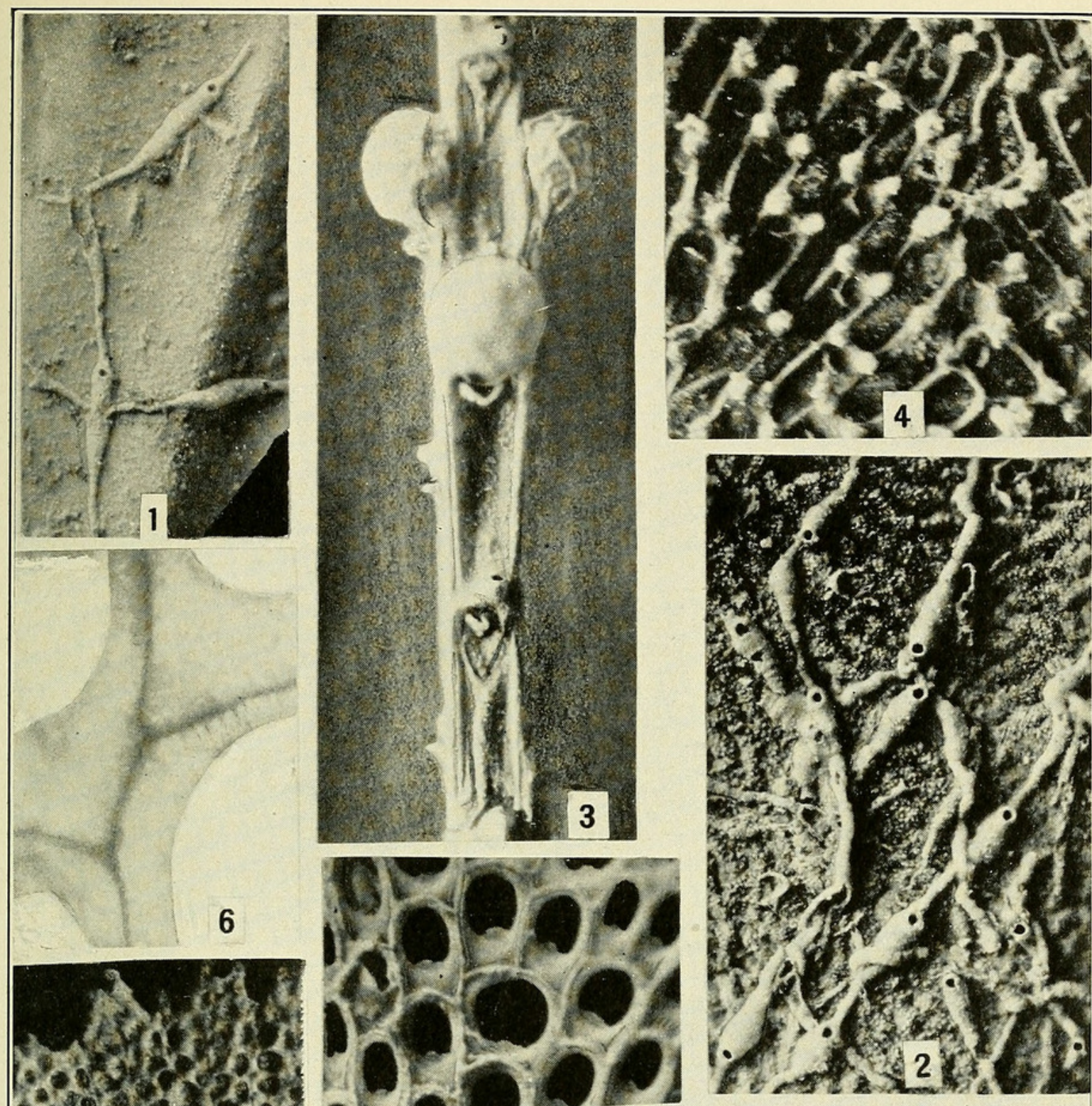

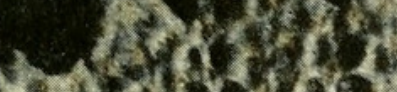

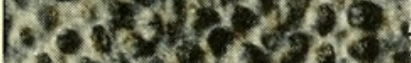

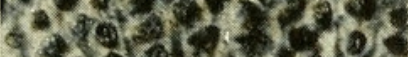

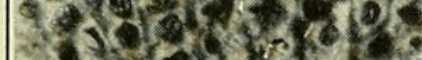

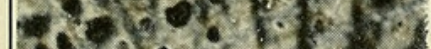

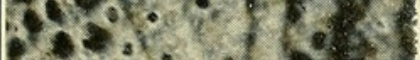

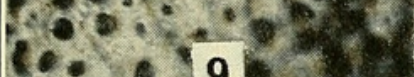
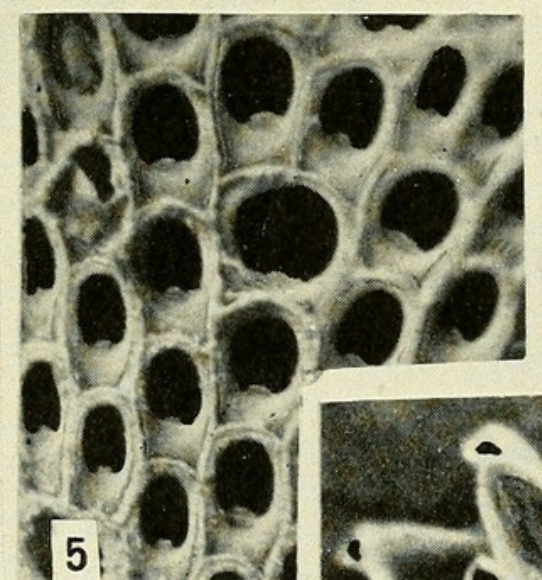

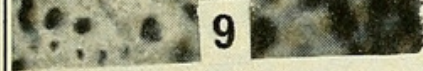
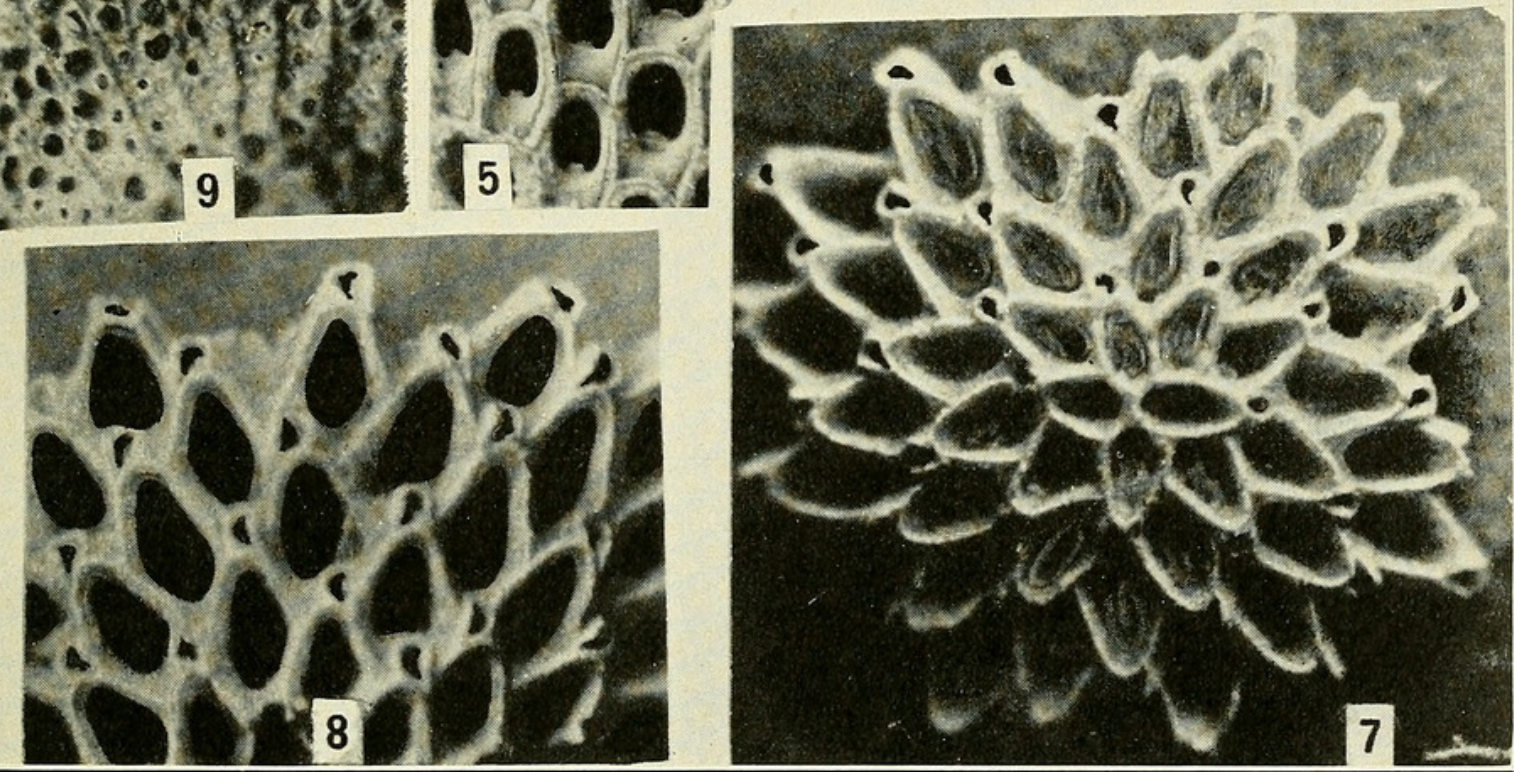

BryozoA of the Gulf of Mexico Region 


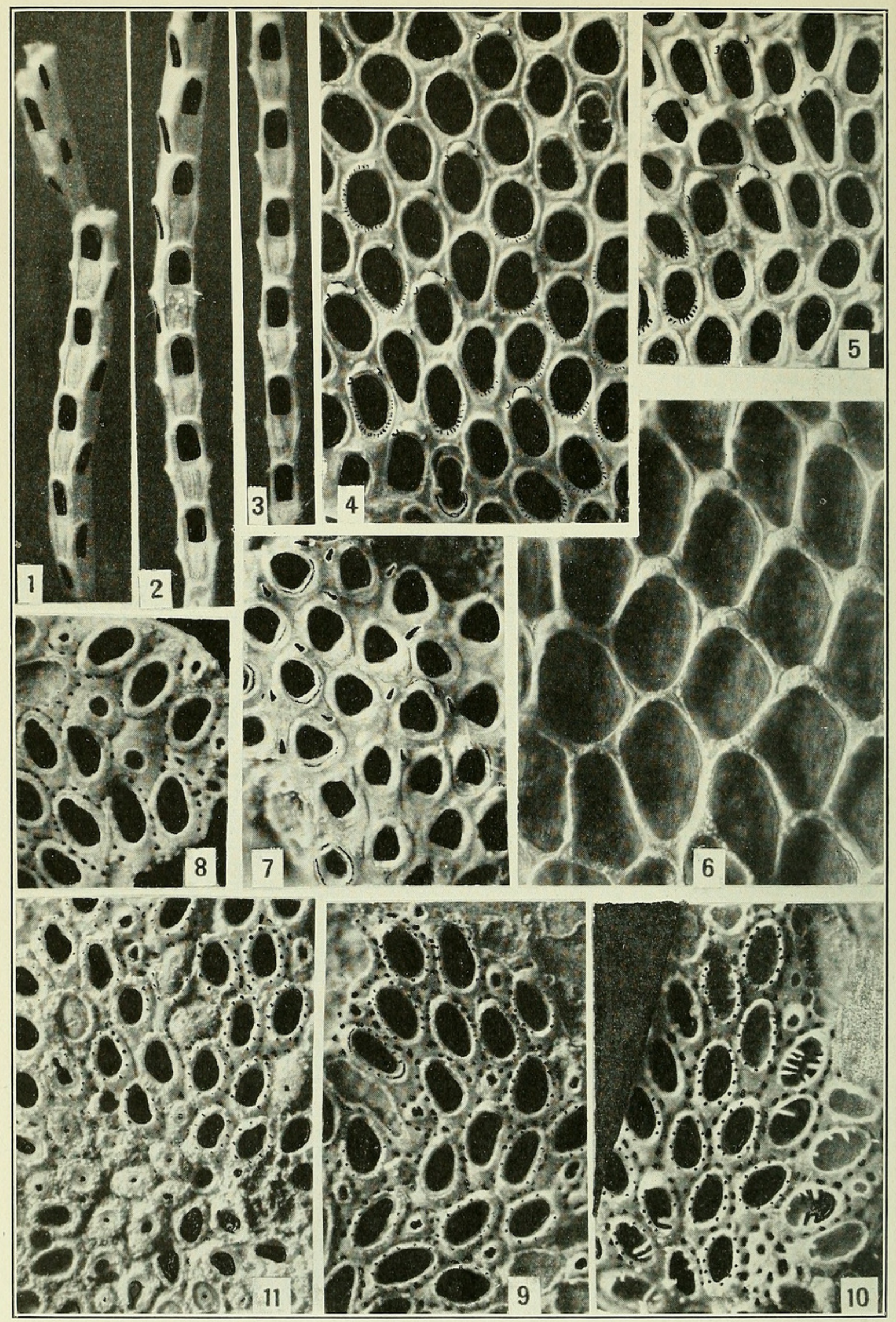

BryozoA of the Gulf of Mexico Region 
Figs. 1-3. Quatricellaria caraibica, new species

1. Segment showing side with small cells and articulation with another segment; $\times 20$.

2,3 . Two segments exhibiting side with large cells; $\times 20$.

Albatross Station D. 2136, Caribbean Sea.

4, 5. Aplousina tuberosa, new species _.......................

4. Portion of the incrusting zoarium with large zooecia and showing the two tubercles arranged on each side of the ovicell; $\times 20$.

5 . Specimen with small zooecia; $\times 20$. Some of the nonovicelled zooecia are tuberose.

Albatross Station D. 2405, Gulf of Mexico.

6. Aplousina gigantea Canu and Bassler, 1927

The incrusting zoarium showing small endozooecial ovicells; $\times 20$.

Albatross Station D. 2405, Gulf of Mexico.

7. Membrendoecium strictorostris, new species

Surface of the incrusting zoarium showing ordinary, ovi-

celled, and regenerated zooecia and the long narrow avicularia; $\times 20$.

Albatross Station D. 2319, north of Cuba.

8-11. Hincksina periporosa, new species

8. Portion of the incrusting zoarium in which two zooeciules are transformed into monstrous zooecia; $\times 20$.

Albatross Station D. 2405, Gulf of Mexico.

9. Ovicelled zooecia showing also zooeciules and interjunctural pores as well as one regenerated zooecium; $\times 20$.

10. Ovicelled and normal zooecia showing the arrangement of the opesial spines.

11. Ancestrula and ancestrular zooecia. Calcified and regenerated zooecia are present; $\times 20$.

Albatross Station D. 2319, north of Cuba. 


\section{Plate 3}

Figs. 1, 2. Marssonopora uncifera, new species

1. The incrusting zoarium showing the stoloniferous zooeciules; $\times 20$.

Albatross Station D. 2319, north of Cuba.

2. Specimen showing the unguiculate spines and the independent existence of the stoloniferous zooeciules which can branch among themselves; $\times 20$. The ovicells are hyperstomial.

Albatross Station D. 2167, off Habana, Cuba.

3. Alderina irregularis Smitt, 1873

Normal and ovicelled zooecia; $\times 20$.

Albatross Station D. 2405, Gulf of Mexico.

4. Callopora tenuirostris Hincks, 1880

Portion of the incrusting, ovicelled zoarium showing the ancestrula. The ancestrular zooecia are smaller than the marginal zooecia (not figured) $; \times 20$.

Albatross Station D. 2639, Straits of Florida.

5, 6. Cribrilina lineata, new species

5 . Incrusting linear branches; $\times 20$.

6 . View showing structure of the costules; $\times 85$.

Albatross Station D. 2152, northwest of Habana Light.

7. Callopora pumicosa, new species

The incrusting zoarium with some ovicelled and regenerated zooecia; $\times 20$. The zooecia are dispersed over a porous calcareous pellicle.

Albatross Station D. 2639, Straits of Florida.

8. Callopora caudata, new species

The incrusting uniserial zooecia branching at right angles; $\times 20$.

Albatross Station D. 2319, north of Cuba.

9, 10. Callopora curvirostris Hincks, 1861

9. Incrusting zoarium with small zooecia, some of which are regenerated; $\times 20$. The falciform avicularia are embedded in special zooecia.

Albatross Station D. 2167, off Habana, Cuba.

10. Ovicelled zoarium with large zooecia; $\times 20$.

Albatross Station D. 2319, north of Cuba.

11. Antropora pustulata, new species. (See also pl. 16, fig. 12.) _-

Zooecia; $\times 20$.

Albatross Station D. 2321, north of Cuba. 


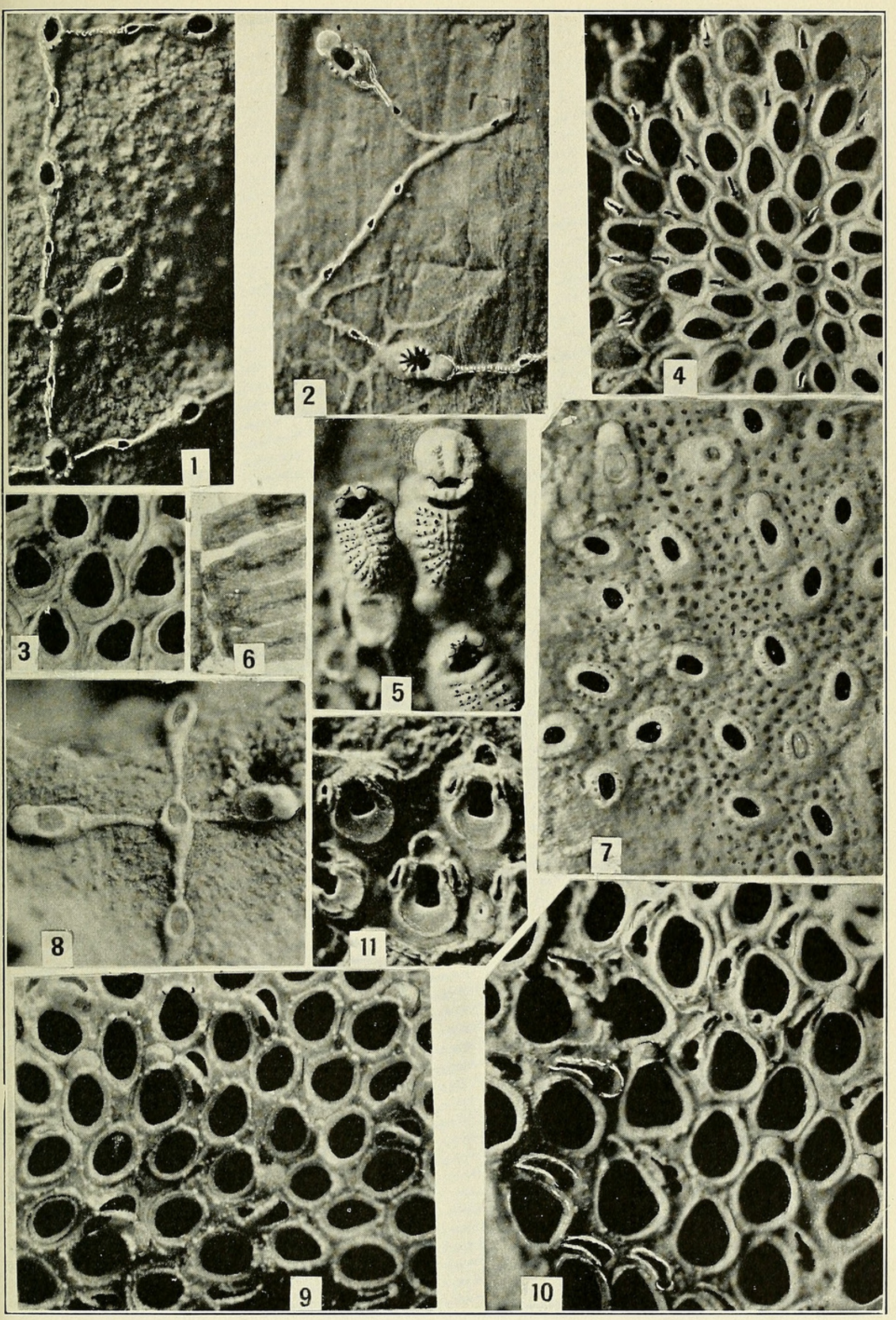

BRyozoA of the GULF of MEXICO REgion

FOR DESCRIPTION SEE PAGE FACING 


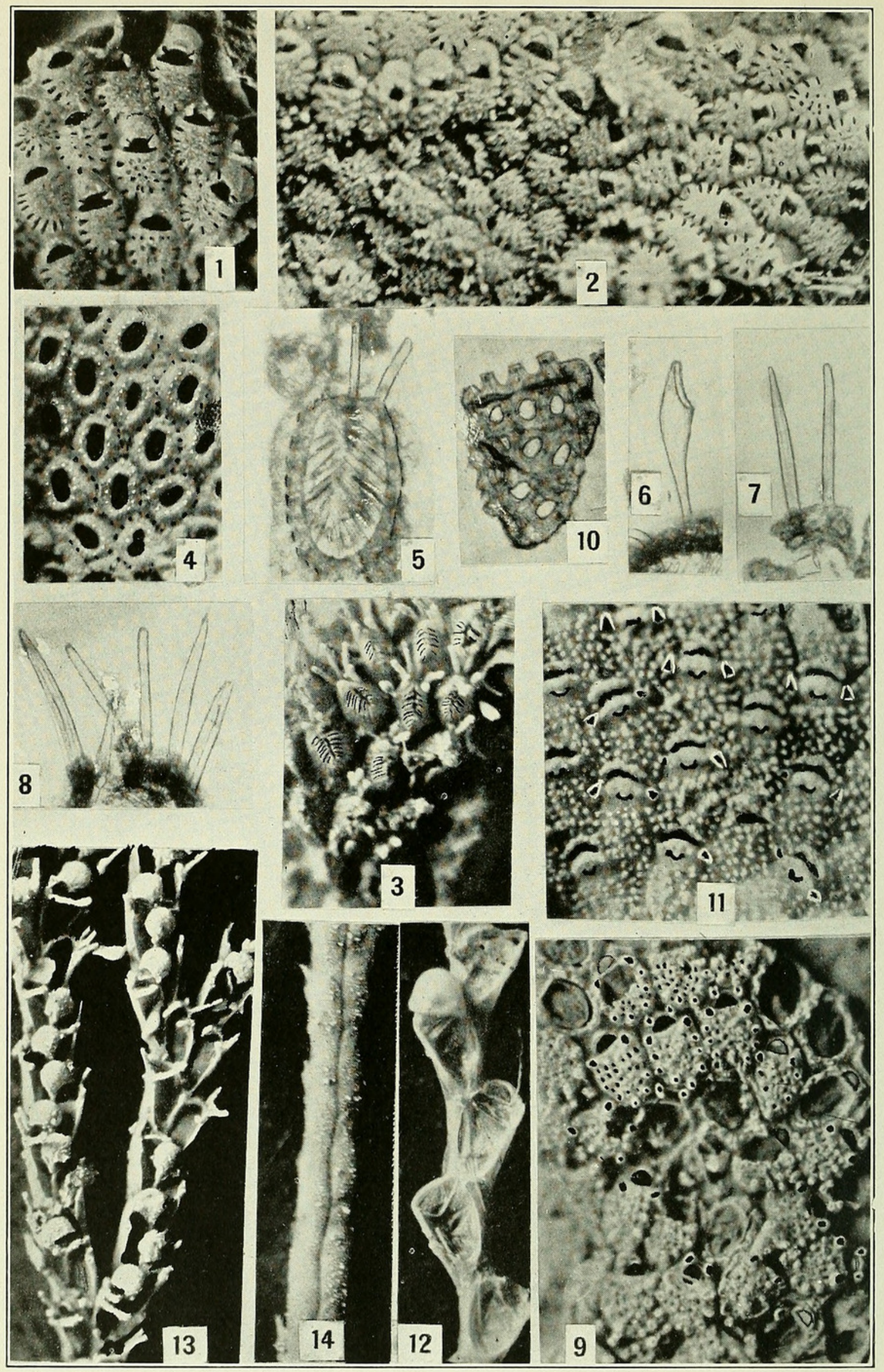

BryozoA of the Gulf of Mexico Region 


\section{Plate 4}

1. Ovicelled specimen with smooth costules; $\times 20$.

Albatross Station D. 2319, north of Cuba.

2. The incrusting zoarium showing ancestrular zooecia with thickened costules; $\times 20$.

Albatross Station D. 2167, off Habana, Cuba.

3-8. Cauloramphus opertus, new species.

3. Specimen with ectocyst, covered by its opesial spines; $\times 20$.

4. Same specimen after boiling in Javelle water; $\times 20$.

5. A zooecium viewed by transparency showing the opesium covered with opesial spines; $\times 50$.

6. View showing structure of pedunculate avicularium; $\times 85$.

7,8 . Views showing structure of distal spines; $\times 85$.

Albatross Station D. 2405, Gulf of Mexico.

9, 10. Acanthocella clypeata, new species

9. The broken part of the frontal showing the presence of the ectocyst under the costules and the membraniporoid structure of the zooecia; $\times 20$.

10. A portion of the frontal showing the structure of the costules. The lumen line has much thickened walls; $\times 85$.

Albatross Station D. 2373, Gulf of Mexico.

11. Gephyrotes spinosum, new species

The incrusting zoarium illustrating spinous aspect of surface; $\times 20$.

Albatross Station D. 2319, north of Cuba.

12. Halophila johnstoniae Gray, 1843

An ovicelled branch with the ectocyst altered in drying.

Albatross Station D. 2405, Gulf of Mexico.

13, 14. Bugula avicularia Linnaeus, 1758

13. Anterior face; $\times 20$.

14. Posterior face; $\times 20$.

Albatross Station 2392, Gulf of Mexico. 
Plate 5

Figs. 1-3. Rectonychocella abyssicola Smitt, 1873

1. Incrusting zoarium, $\times 3$, showing free vincularian expansions.

2. A portion of the same zoarium in the vicinity of the ancestrula; $\times 20$.

3. Zooecia, $\times 20$, of another zoarium, some distance from the ancestrula.

Albatross Station D. 2152, northwest of Habana Light.

4-8. Dacryonella typica, new species

4. Ordinary zooecia of the incrusting zoarium; $\times 20$.

5. Group of small zooecia on an ovicelled specimen; $\times 20$.

6. Extremity of a zoarium showing the great irregularity of the marginal zooecia; $\times 20$.

7. Group of zooecia with large opesiular indentations; $\times 20$.

8. Another group of zooecia; $\times 20$.

Albatross Stations D. 2319, and D. 2320, north of Cuba.

9-14. Dendrobeania lamellosa, new species

9. Anterior face of an ovicelled frond; $\times 20$.

10. Posterior face showing the mode of branching; $\times 20$.

11, 12. Structure of articulated opesial spines; $\times 25$ and $\times$ 85 .

13, 14. Structure of the pedunculated avicularium; $\times 25$ and $\times 50$.

Albatross Station D. 2354, east of Yucatan. 

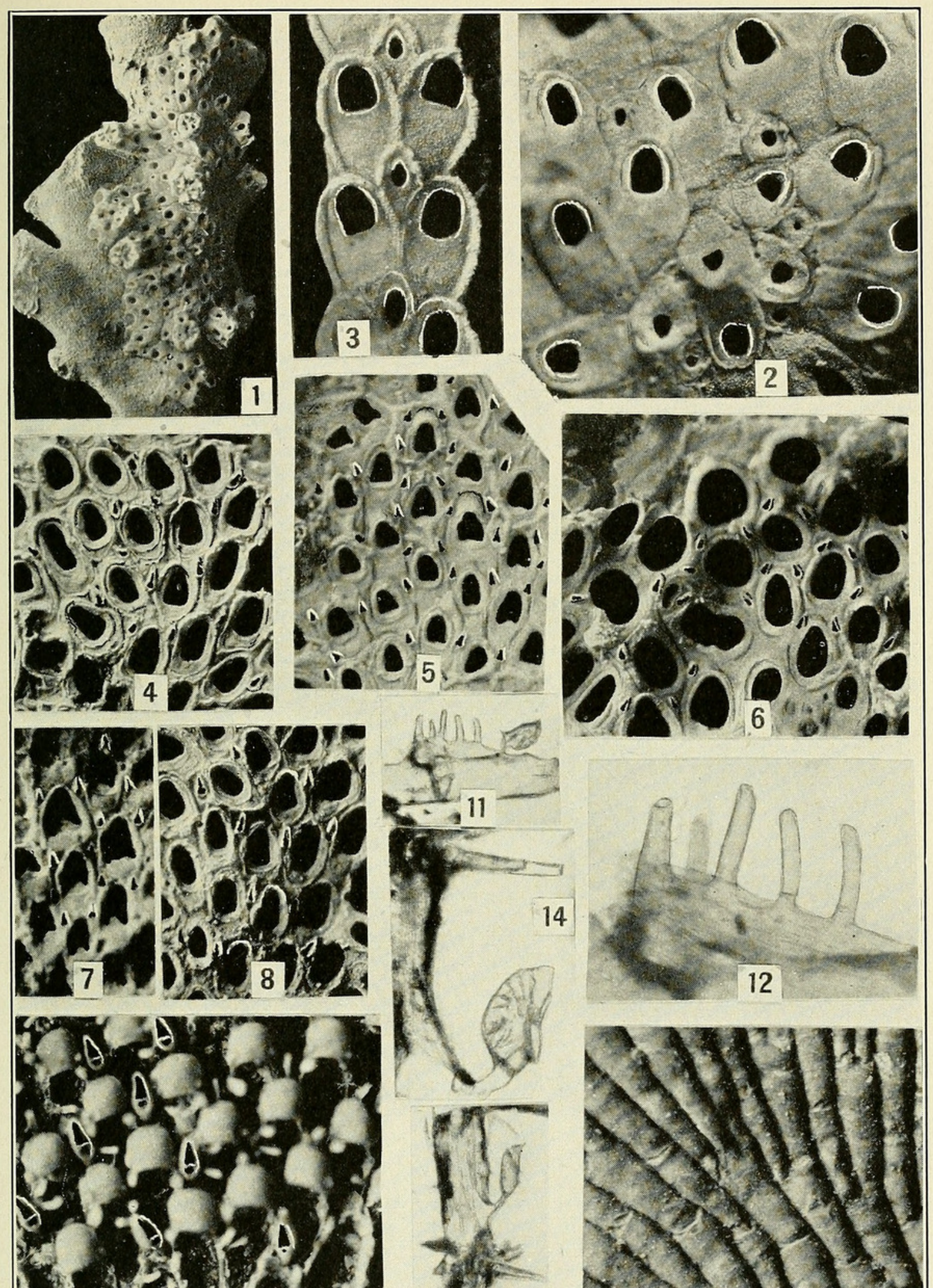
are 1 , 110. + 110 1. I

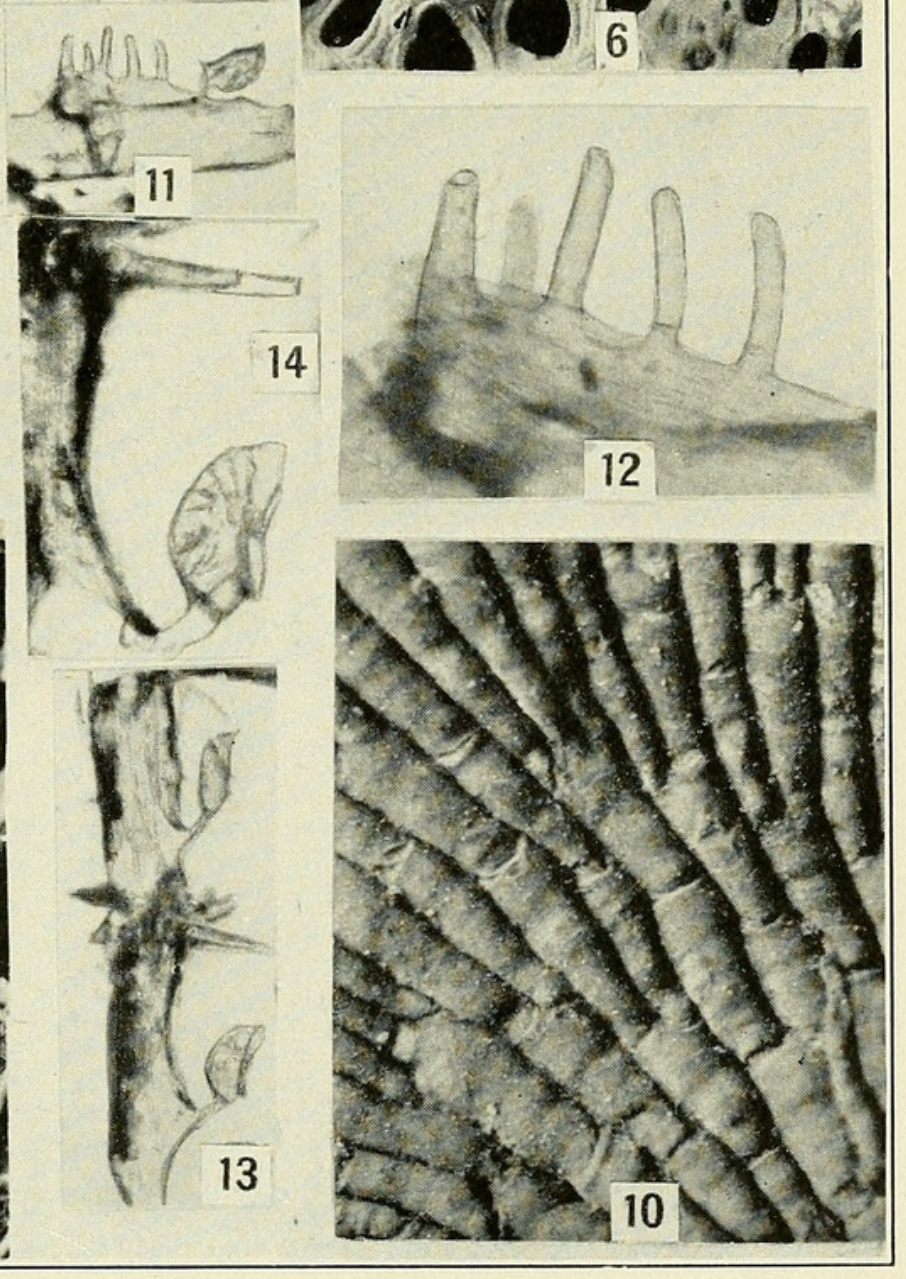

BryozoA of the Gulf of MExico Region 


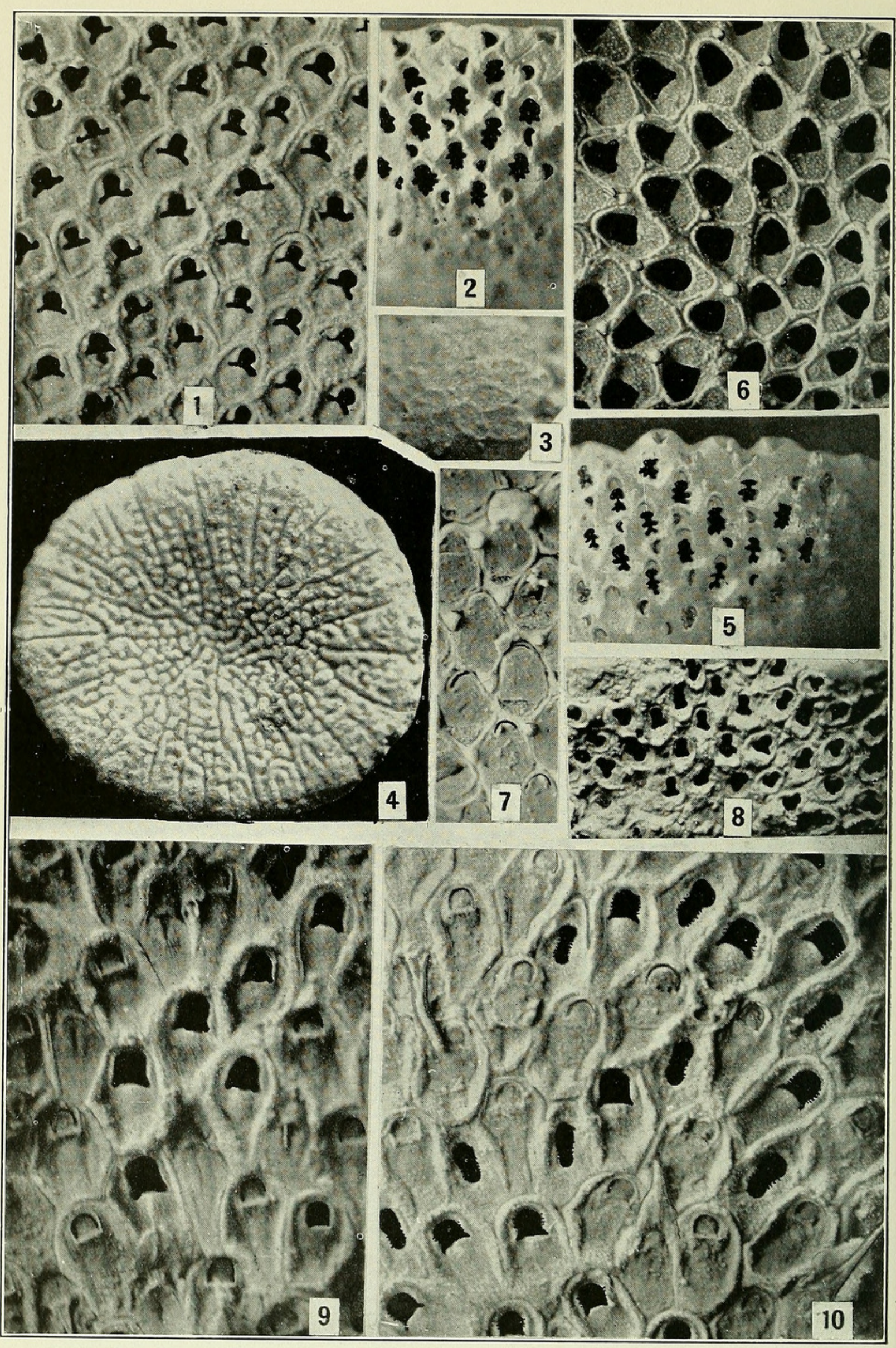


FIG. 1. F'loridina antiqua Smitt, 1873

The incrusting zoarium showing typical features; $\times 20$.

Albatross Station D. 2405, Gulf of Mexico.

2-5. Cupularia doma D'Orbigny, 1852

2. Lateral view of a colony having few initial zooecia; $\times 20$.

3. Superior view (apex) of a colony with initial zooecia; $\times 20$. There are eight zooecia around the ancestrula.

4. Tuberose base of a colony; $\times 20$.

5. Lateral view of a colony having numerous initial cells; $\times 20$.

Albatross Station D. 2639, Straits of Florida.

6, 7. Floridinella typica, new species

6 . The incrusting zoarium, $\times 20$, with ectocyst removed.

7. Zooecia covered by ectocyst and showing the interzooecial tuberosities; $\times 20$. The opercular valve is supported on the mural rim.

Atlantic Ocean, 15 miles south of Miama, Fla.

8. Floridinella parvula, new species

The incrusting zoarium showing the small trifoliate zooecia; $\times 20$.

Albatross Station 2639, Straits of Florida.

9, 10. Velumella americana, new species

9. The incrusting zoarium with ovicells; $\times 20$. Sometimes the onychocellaria have lost their mandibles.

10. Zoarium in which many of the zooecia are covered by the ectocyst; $\times 20$.

Albatross Station D. 2405, Gulf of Mexico. 


\section{Plate 7}

FIgs. 1-3. Cupularia umbellata Defrance, 1823

1. Hydrostatic zooecia; $\times 20$.

2. Interior face; $\times 20$.

3. Marginal zooecia; $\times 20$.

Florida Keys, Gulf of Mexico.

4-7. Siphonoporella dumonti, new species _.......................

4. Interior of a colony, showing the oblique position of the polypidian tube; $\times 20$.

5. A compressed frond with the ectocyst preserved. The $\mathrm{B}$ zooecium has the opercular mandible; $\times 20$.

6. Cylindrical specimen without ectocyst showing the place of the polypidian tube (=siphon) B zooecium with opercular mandible present; $\times 20$.

7. Cylindrical specimen with ectocyst; $\times 20$.

Albatross Station D. 2405, Gulf of Mexico.

8-10. Steganoporella magnilabris Busk, 1854

8. Photograph of the retractor muscles; $\times 85$.

9. Specimen with ectocyst; $\times 20$. The small symmetric concavities of the ectucyst indicate the place of the opesiular muscles.

10. Zooecia, $\times 20$, without ectocyst.

Atlantic Ocean, Fowey Light, 15 miles south of Miami, Fla. 


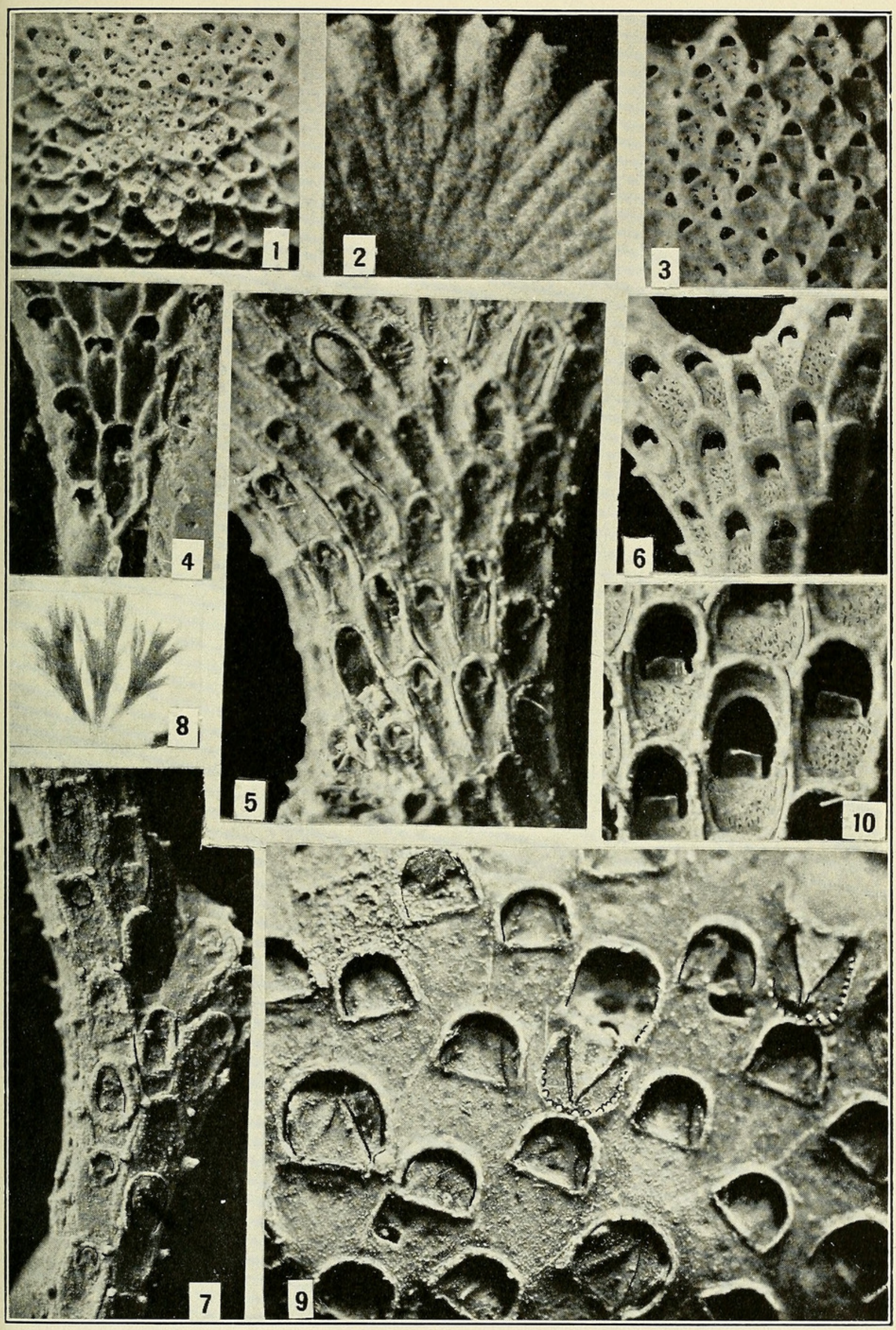

BRyozoA of the Gulf of MEXICO REgion 


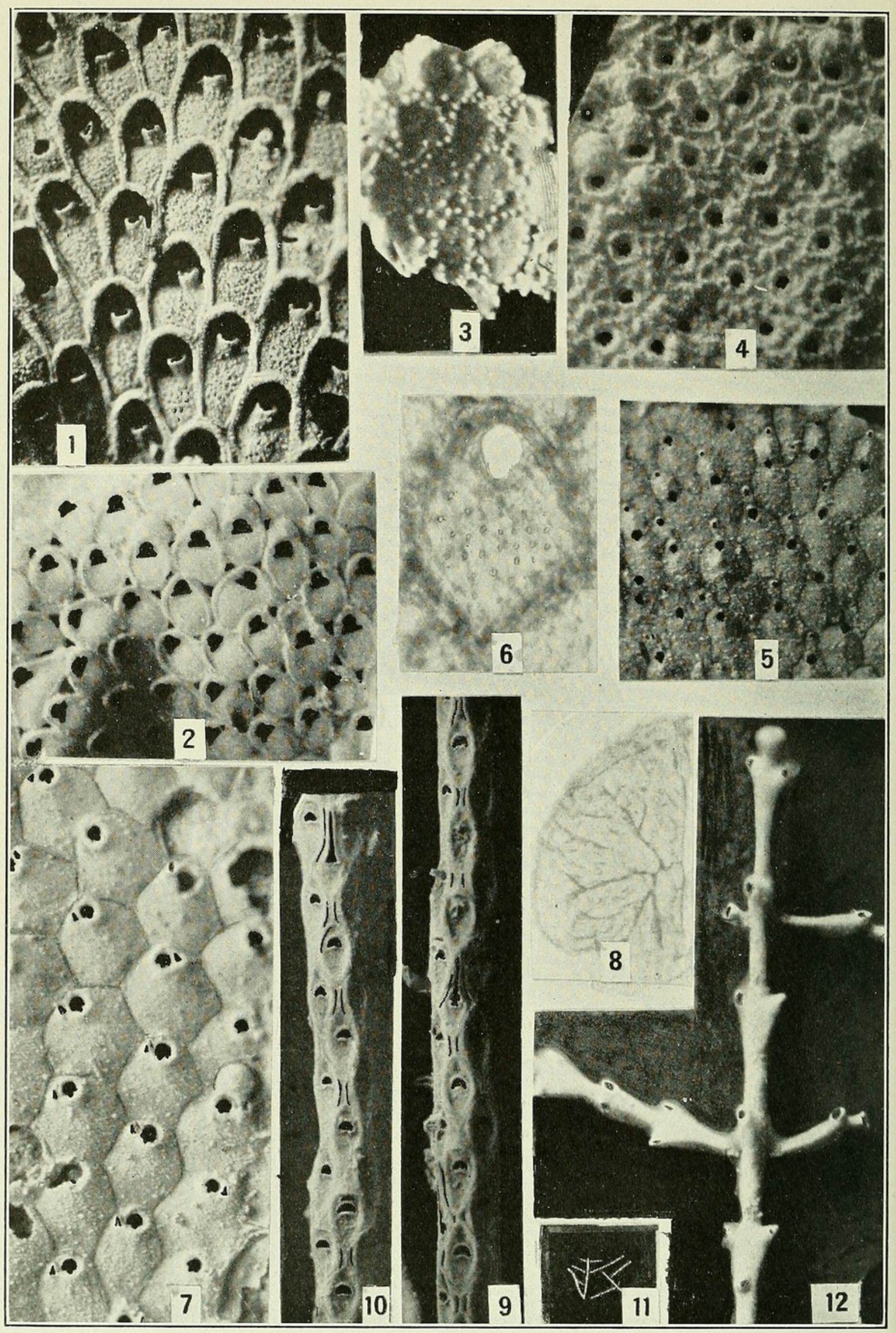

BryozoA of the Gulf of MExico Region 


\section{Plate 8}

FIg. 1. Siphonoporella granulosa, new species

Page

The incrusting zoarium illustrating the granular cryptocyst; $\times 20$.

Atlantic Ocean, 15 miles south of Miami, Fla.

2, 3. Mollia patellaria Smitt, 1873

2 . The incrusting zoarium with normal and ovicelled zooecia; $\times 20$.

3. Inferior face showing the small tuberosities bearing the small radicular nibers; $\times 20$.

Albatross Station D. 2405, Gulf of Mexico.

4. Buffonellaria reticulata, new species

The incrusting zoarium with ovicelled zooecia and showing the reticulation of the zooecial frontal; $\times 20$.

Albatross Station D. 2405, Gulf of Mexico.

5, 6. Trypostega venusta Norman, 1864

5. The incrusting zoarium with ovicelled zooecia; $\times 20$.

6. A zooecium viewed by transparency and showing the structure of the frontal and the form of the aperture; $\times 85$.

Albatross Station D. 2405, Gulf of Mexico.

7, 8. Buffonellaria divergens Smitt, 1873

7. Surface of the incrusting zoarium; $\times 20$.

8. Structure of the frontal, an olocyst with radial fibers; $\times 85$.

Albatross Station D. 2167, off Habana, Cuba.

9-10. Cellaria nodosa, new name

9. Portion of a segment showing the large avicularium; $\times 20$.

10. Fragment of an ovicelled segment; $\times 20$. The nodosity bears the much larger ovicelled zooecium.

Albatross Station D. 2388, Gulf of Mexico.

11-12. Pasythea eburnea Smitt, 1873.

Principal and secondary branches; $\times 1$ and 20 .

Albatross Station D. 2331, north of Cuba. 


\section{Plate 9}

Figs. 1-4. Schizopodrella incrassata, new species _..................

1. Fragment of a colony with two coalescent fronds; $\times 6$

2. Group of ovicelled zooecia in the middle of a frond; $\times 20$.

3. Young zooecia at the extremity of a branch; $\times 20$.

4. Zooecia viewed by transparency, $\times 85$, showing the tremopores and the frontal structure.

Albatross Station D. 2405, Gulf of Mexico.

5. Gemelliporidra aculeata, new species

The incrusting zoarium; $\times 20$.

Fowey Light, 15 miles south of Miami, Fla.

6. Hippodiplosia pertusa Esper, 1794

Incrusting specimen with several ovicelled zooecia. Some of the cells have preserved their opercula; $\times 20$.

Albatross Station D. 2362, east of Yucatan.

7. Hippoporina cleidostoma Smitt, 1873

Incrusting specimen showing the variations of the aperture and the avicularia; $\times, 20$.

Albatross Station D. 2405, Gulf of Mexico.

8. Hippadenella floridana, new species

Incrusting specimen, $\times 20$, showing the median avicularian chamber. The thick ectocyst hides the areolar pores.

Cedar Keys, Fla.

9. Hemiseptella denticulata Smitt, 1872

A specimen, $\times$ 20, exhibiting some deformed zooecia.

Punta Rosa, Fla. 


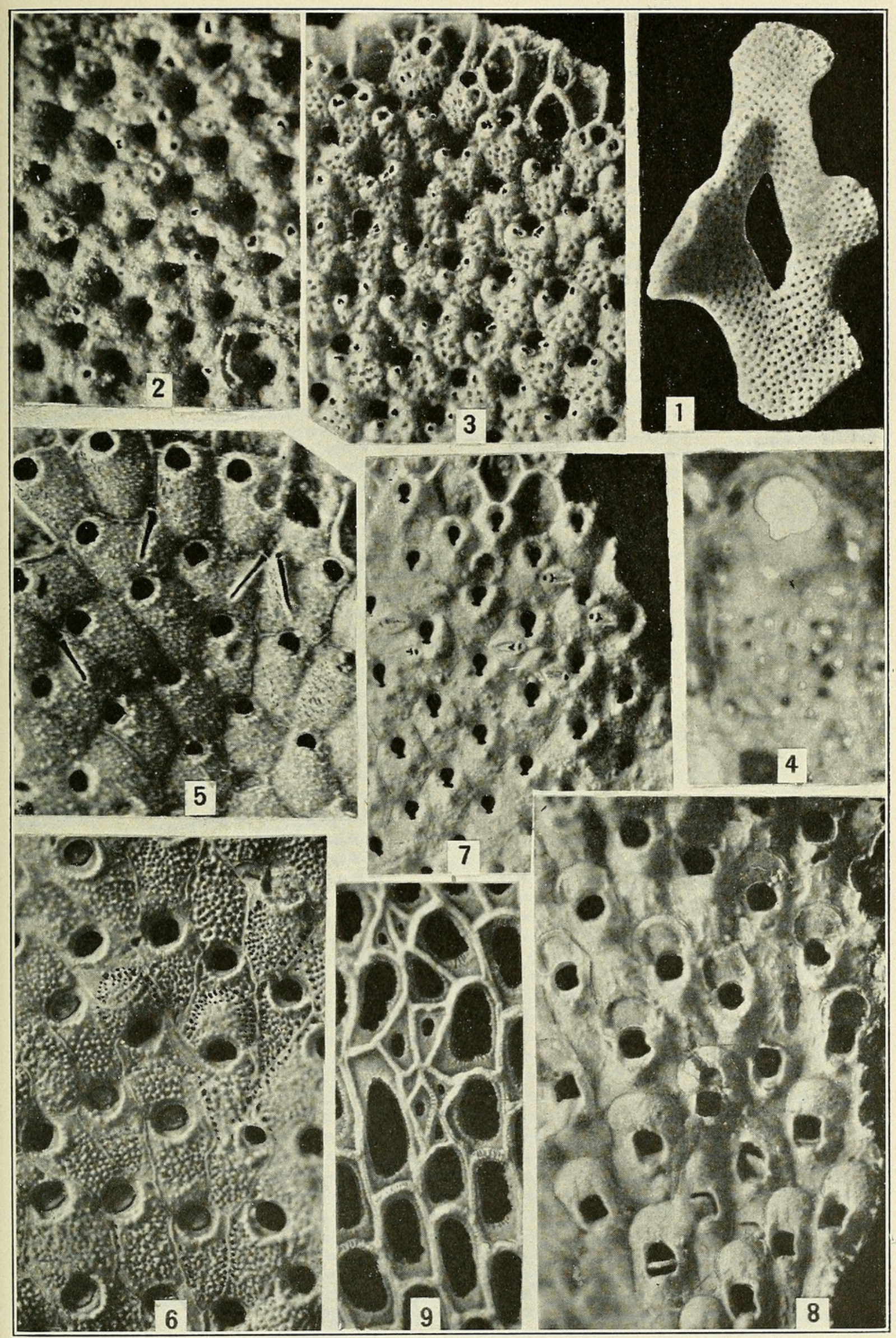

Bryozoa of the Gulf of Mexico Region 


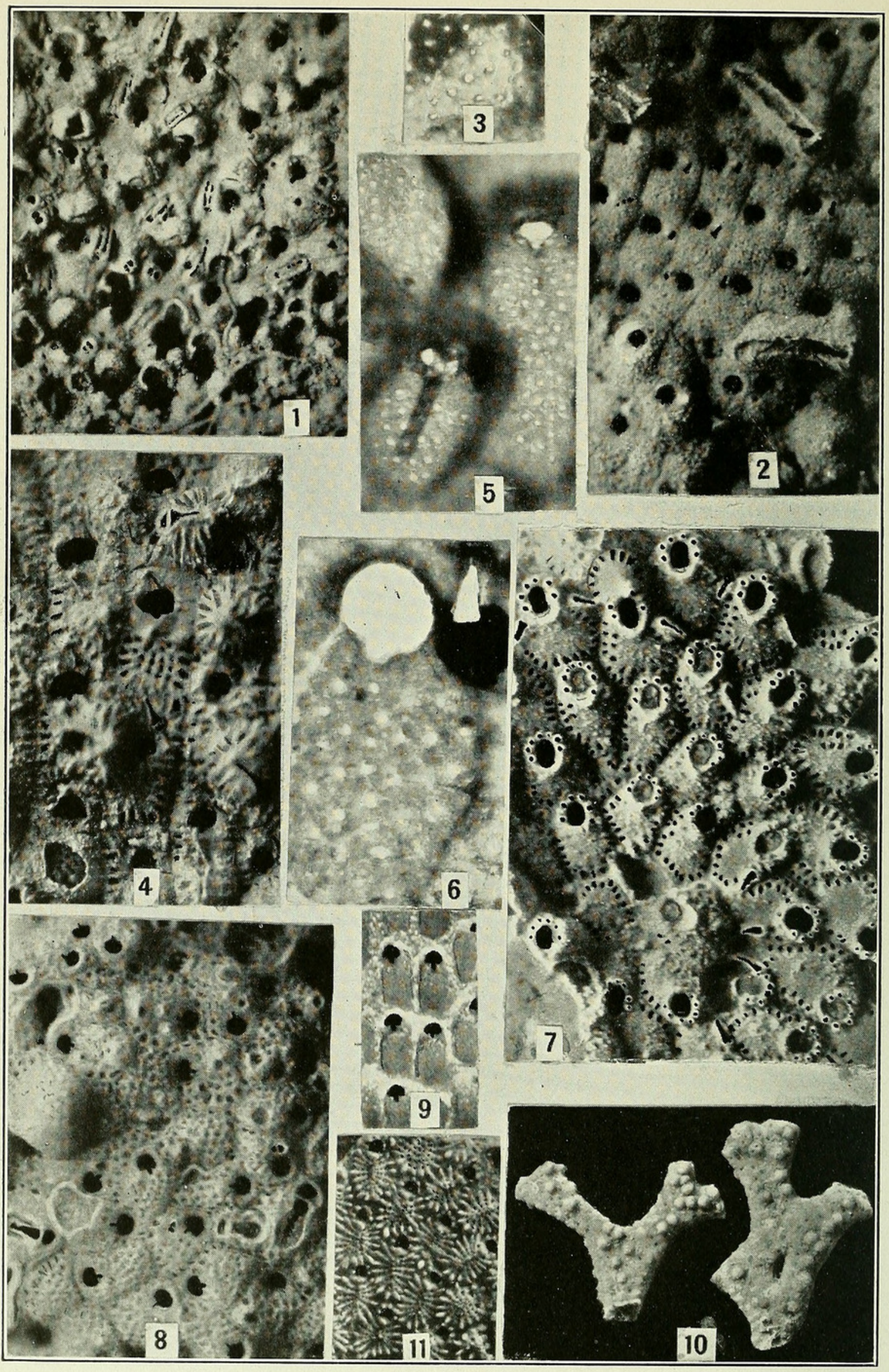

Bryozoa of the Gulf of Mexico Region 
Fig. 1. Gemelliporella asper Canu and Bassler, 1923_............. 90

Ovicelled incrusting colony; $\times 20$.

Albatross Station D. 2322, north of Cuba.

2, 3. Schizopodrella falcifera, new species.

2 . Incrusting specimen, $\times 20$, exhibiting the small avicularia and the sporadic large falciform ones.

3 . Structure of the frontal; $\times 85$.

Albatross Station D. 2365, east of Yucatan.

4-6. Schizopodrella floridana Osburn, 1914_...................

4. Surface of zoarium; $\times 20$, with ovicelled and nonovicelled zooecia.

5. Structure of the frontal; $\times 40$. The tentacular sheath is visible in one zooecium.

6. Frontal of zooecial; $\times 85$.

Albatross Station D. 2363, east of Yucatan.

7. Hippomenella rubra, new species

Incrusting ovicelled specimen; $\times 20$. Some of the cells are operculated.

Albatross Station D. 2405, Gulf of Mexico.

8-10. Stylopoma spongites Pallas, 1766

8. Group of nonoriented cells on a bilamellar frond; $\times 20$.

9. Interior showing the form of aperture and absence of condyles; $\times 20$.

10. Bilamellar fronds; $\times 2$.

Albatross Station D. 2405, Gulf of Mexico.

11. Puellina radiata Moll, 1803

Ordinary zooecia; $\times 20$.

Albatross Station D. 2650, Bahama Islands. 
Figs 1-4. Gemelliporidra typica, new species

1. Multilamellar ovicelled specimen much calcified, showing a transverse spatulate avicularium; $\times 20$.

Albatross Station D. 2330, north of Cuba.

2. Unilamellar specimen; $\times 20$, with opercula in some zooecia.

Albatross Station D. 2390, north of Cuba.

3. Interior; $\times 20$, showing the aperture removed from the distal border of the zooecium.

4. Frontal viewed by transparency, showing the true form of the aperture: $\times 20$.

Albatross Station D. 2167, off Habana, Cuba.

5-11. Gemelliporidra magniporosa Canu and Bassler, 1923

5. Incrusting specimen; $\times 20$, with regularly oriented zooecia. The avicularia are erect.

6. Unilamellar specimen; $\times 20$, showing the formation of inverted zooecia.

7. Unilamellar specimen with giant zooecia; $\times 20$.

Albatross Station D. 2169, off Habana, Cuba.

8 . Structure of the frontal; $\times 85$.

9. Multilamellar example; $\times 20$, with inverted zooecia. Albatross Station D. 2362, east of Yucatan.

10. Unilamellar ovicelled specimen; $\times 20$. Some apertures have preserved their opercula.

11. Zoarium, natural size.

Albatross Station D. 2157, off Habana, Cuba. 


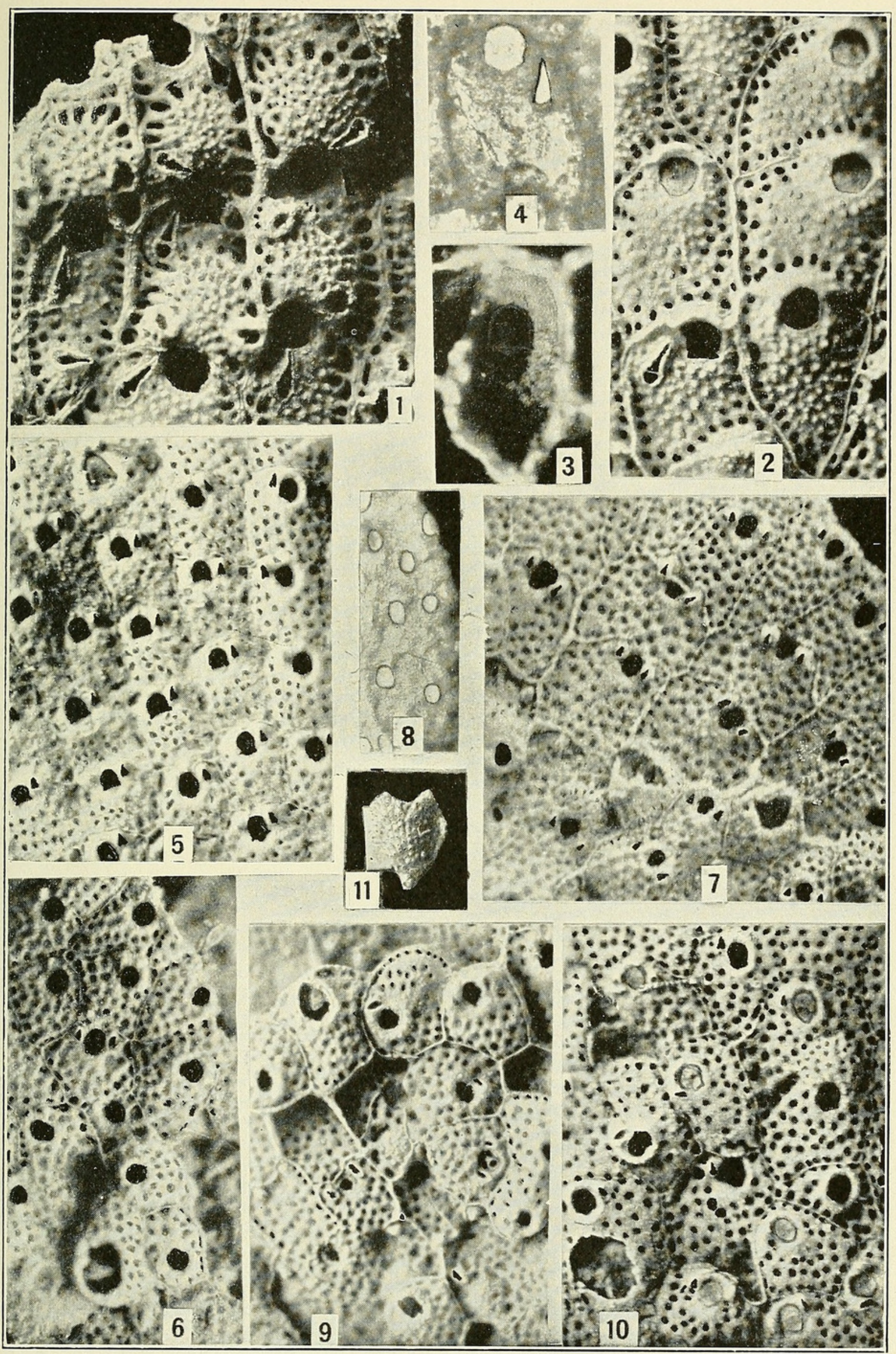

BryozoA of the Gulf of Mexico Region 


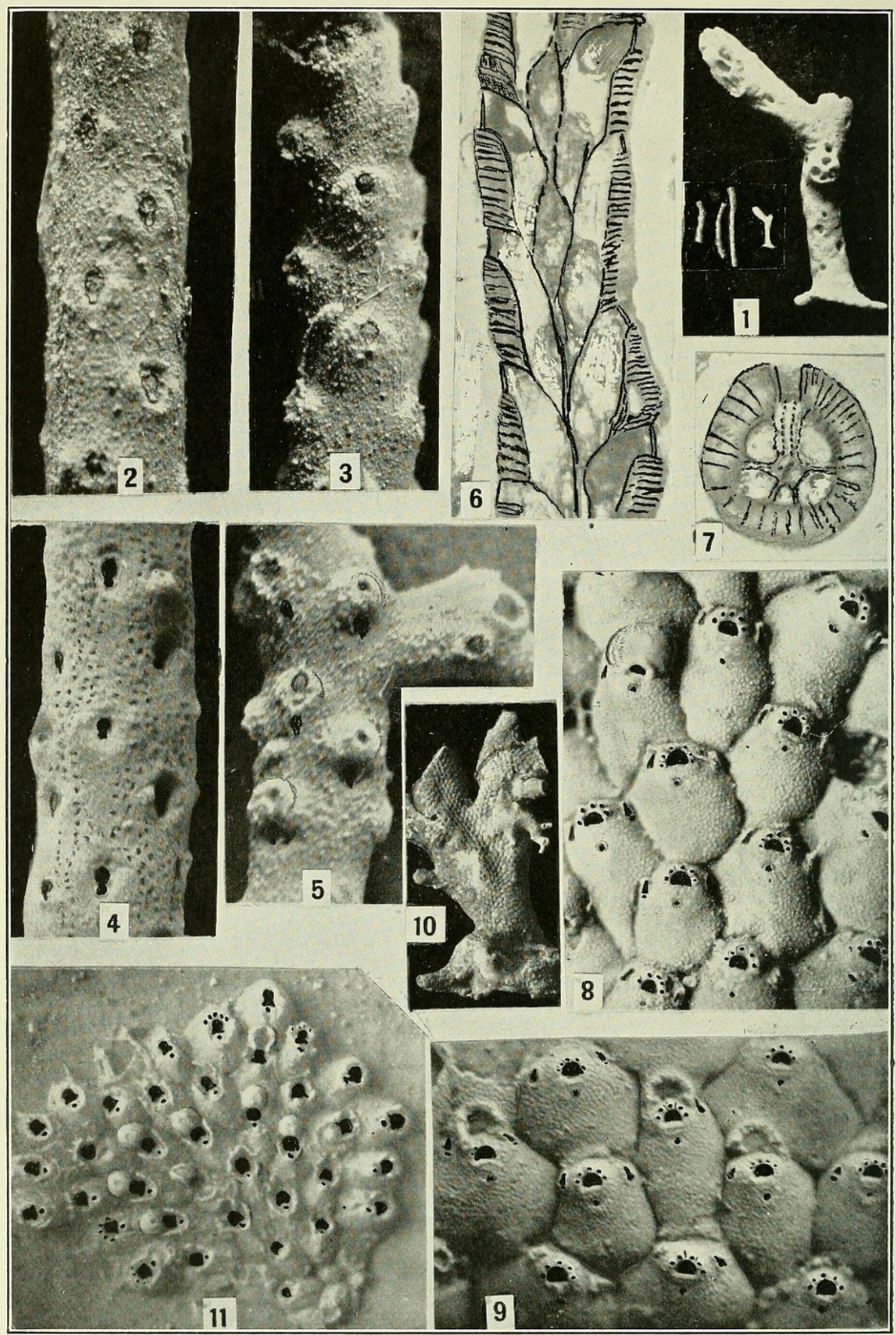

Bryozoa of the Gulf of Mexico Region 
Figs. 1-7. Gemellipora glabra Smitt, 1873_.

1. Fragment, natural size and base of a branching colony; $\times 6$.

2. Example; $\times 20$, with ectocyst and opercula preserved.

3 . Extremity of a young branch, $\times 20$, with ectocyst.

4. Specimen without ectocyst, showing the frontal pores; $\times 20$

5. Ovicelled specimen; $\times 20$, showing the median cicatrix of the ovicell.

6. Longitudinal thin section; $\times 25$.

7. Transverse thin section through the plane of an aperture; $\times 25$.

Fowey Light, 15 miles south of Miami, Fla., and Albatross Station D. 2405, Gulf of Mexico.

8-10 Microporella ampla, new species

8. Incrusting ovicelled specimen; $\times 20$.

9. Another portion of the same exhibiting the great variations of the zooecial width; $\times 20$.

10. Encrusting zoarium, natural size.

Albatross Station D. 2152, 21/2 miles northwest of Habana, Cuba.

11. Lepralia palliolata, new species

The incrusting type specimen; $\times 20$.

Albatross Station D. 2639, Straits of Florida. 
1. Incrusting ovicelled specimen with long zooecia; $\times 20$.

2 . Portion of the same zoarium; $\times 20$, in which the zooecia are broad and the pleurocyst is thick.

Albatross Station D. 2672, Atlantic, east of Georgia.

3, 4. Tremogasterina granulata, new species

3. Portion of a unilamellar, much calcified colony. The frontal pore is little apparent and hidden by the pleurocyst; $\times 20$.

4. Interior showing the two apertural cardelles and the frontal pores; $\times 20$.

Fowey Light, 15 miles south of Miami, Fla.

5-8. Tremogasterina malleolus, new species......................

5. Unilamellar, ovicelled zoarium showing the mandible in place; $\times 20$.

6. A large avicularium replacing a zoozcium. The distal spines are large. The mucron is much dilated at its extremity.

7. Frontal of several zooecia showing the form and the arrangement of the frontal pores.

8. Portion of an unilamellar zoarium; $\times 20$, showing the large distal spines.

Albatross Station D, 2404, Gulf of Mexico.

9. Tremogasterina lanceolata, new species

Fragments of the unilamellar zoarium; $\times 20$. The pleurocyst is thick.

Albatross Station C. 2320, north of Cuba. 


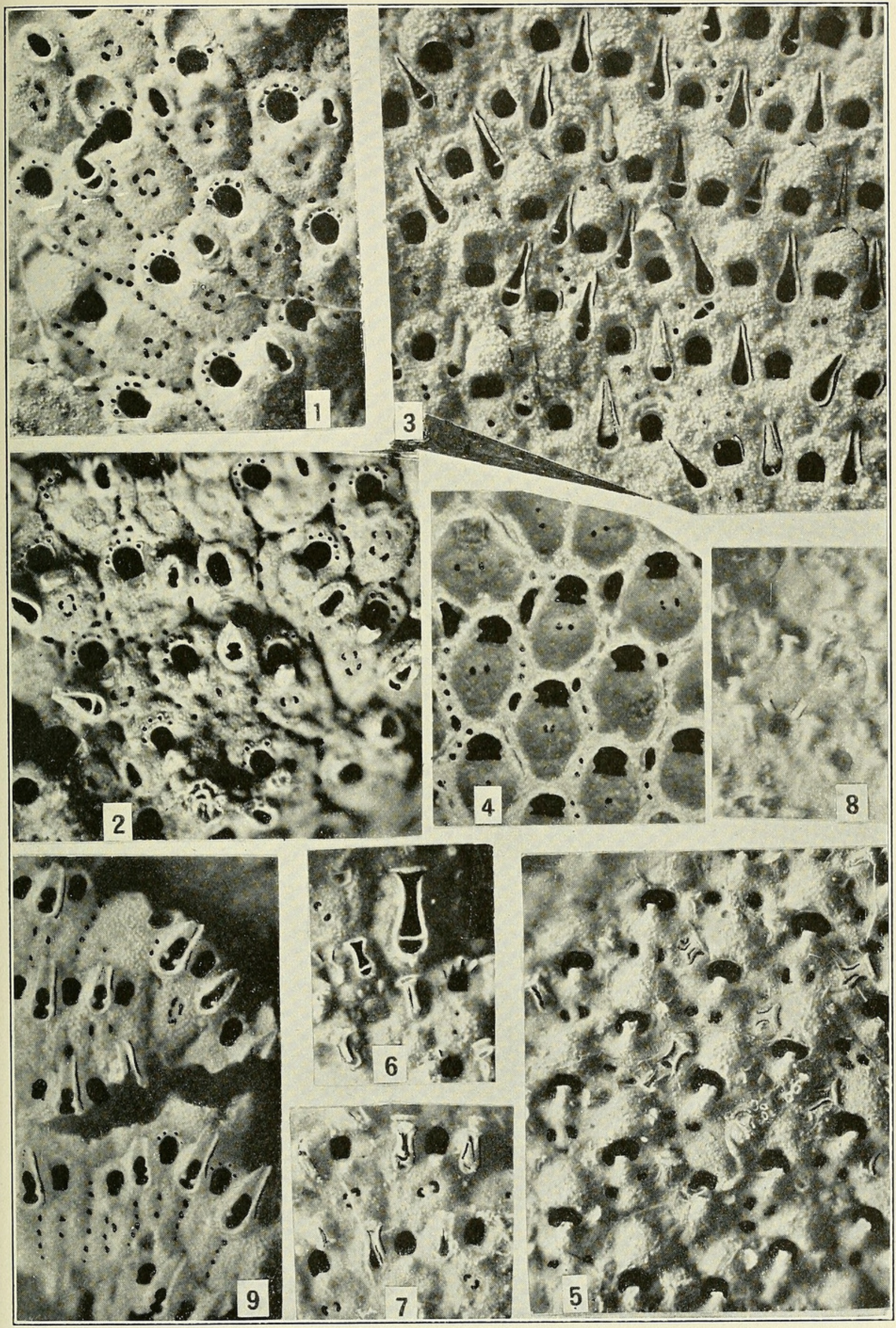

BryozoA of the Gulf of MEXico REgion 


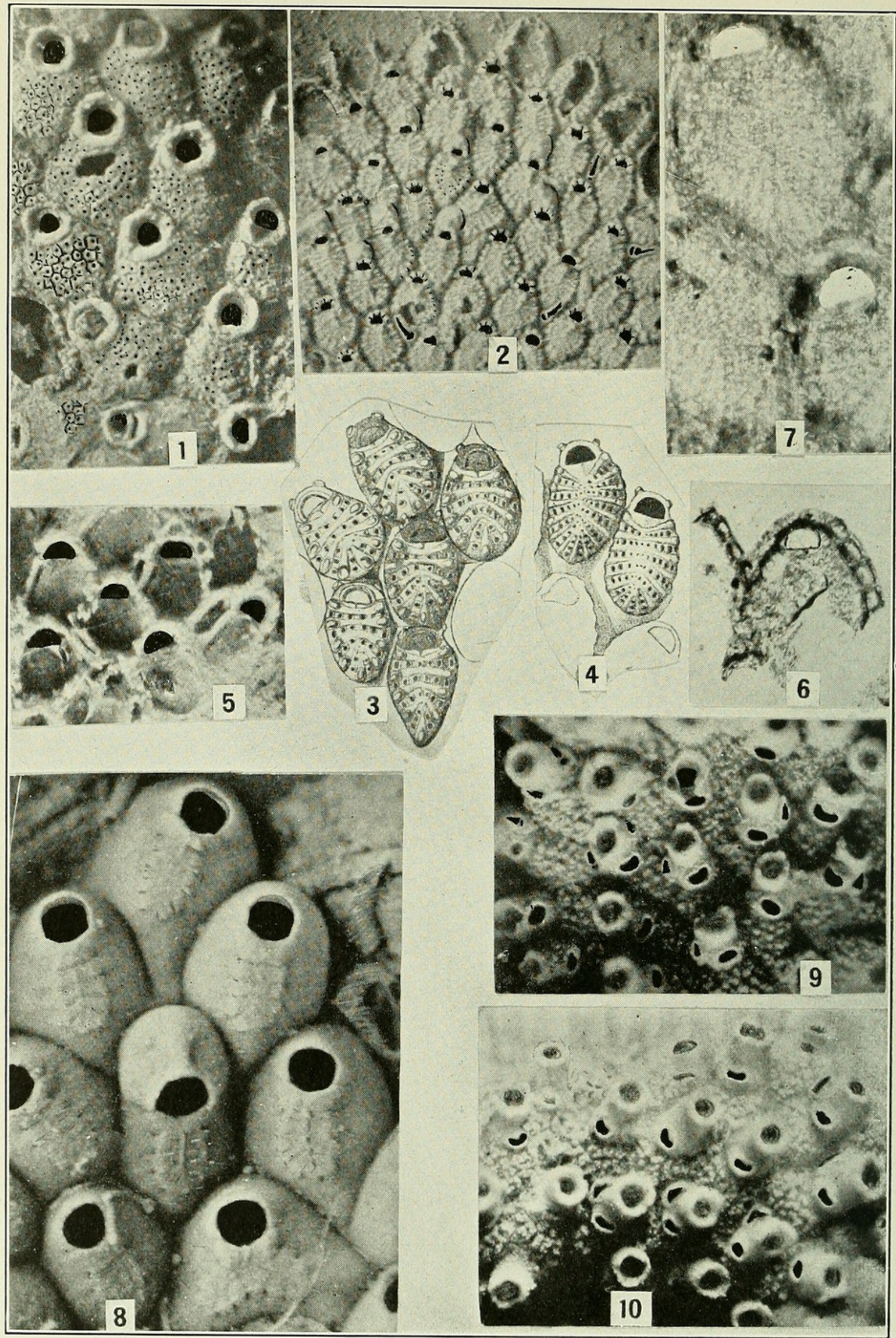

BryozoA of the Gulf of Mexico Region

FOR DESCRIPTION SEE PAGE FACINO 


\section{Plate 14}

Zooecia of the incrusting zoarium; $\times 20$.

Fowey Light, 15 miles south of Miami, Fla.

2. Puellina innominata Couch, 1844

Zoarium, $\times 20$, showing the tuberosities surrounding each zooecium.

Albatross Station D. 2405, Gulf of Mexico.

3-7. Puellina floridana Smitt, 1873

3, 4. Zoarial surfaces, $\times 20$ (after Smitt, 1873).

5. Interior; $\times 20$. The costules are not visible.

6. Zooecium, $\times 50$, seen by transparency, illustrating arrangement of dietellae.

7. Thin section, $\times 85$, showing structure of the frontal.

Albatross Station D. 2405, Gulf of Mexico.

8. Figularia (?) ampla, new species

The incrusting type specimen; $\times 20$.

Albatross Station D. 2167, off Habana, Cuba

9, 10. Stenopsis fenestrata Smitt, 1873

9. The incrusting zoarium, $\times 20$, showing the great length of the peristomie.

10. Another view of the same; $\times 20$.

Albatross Station D. 2405, Gulf of Mexico. 


\section{Plate 15}

Figs. 1-4. Semihaswellia sinuosa, new species

1. A segment with its branches; $X .6$.

2. Ovicelled segment; $\times 20$.

3. Dorsal of a segment, $\times 20$, showing the longitudinal sulci and the small sporadic avicularia.

4. Portion of a segment showing the chitinous articulation of a branch on a basis ramae.

Albatross Station D. 2392, Gulf of Mexico.

5. Tessaradoma gracile Sars, 1850 , variety

Portion of a branch, $\times 20$, exhibiting large dimensions.

Albatross Station D. 2117, Caribbean Sea.

6. Tubucellaria cereoides Ellis and Solander, 1786

Portion of a segment; $\times 20$.

Fowey Light, 15 miles south of Miami, Fla.

7, 8. Cystisella americana, new species

The bilamellar ovicelled type specimen, natural size and surface; $\times 20$.

Albatross Station D. 2387, Gulf of Mexico.

9-13. Smittina trispinosa spathulata Smitt, 1873

9 . Interior, $\times 20$, showing the arrangement of the lyrule and the cardelles at the same level.

10, 11. Two variations, $\times 20$, showing form of the large spathulated avicularium.

12. Surface of unilamellar specimen, $\times 20$, with avicularia long and very thin. There are small avicularia around the ape,ture.

13. Unilamellar ovicelled specimen, $\times 20$, with long thin avicularia and without spathulated avicularia.

Fowey Light, 15 miles south of Miami, Fla. 

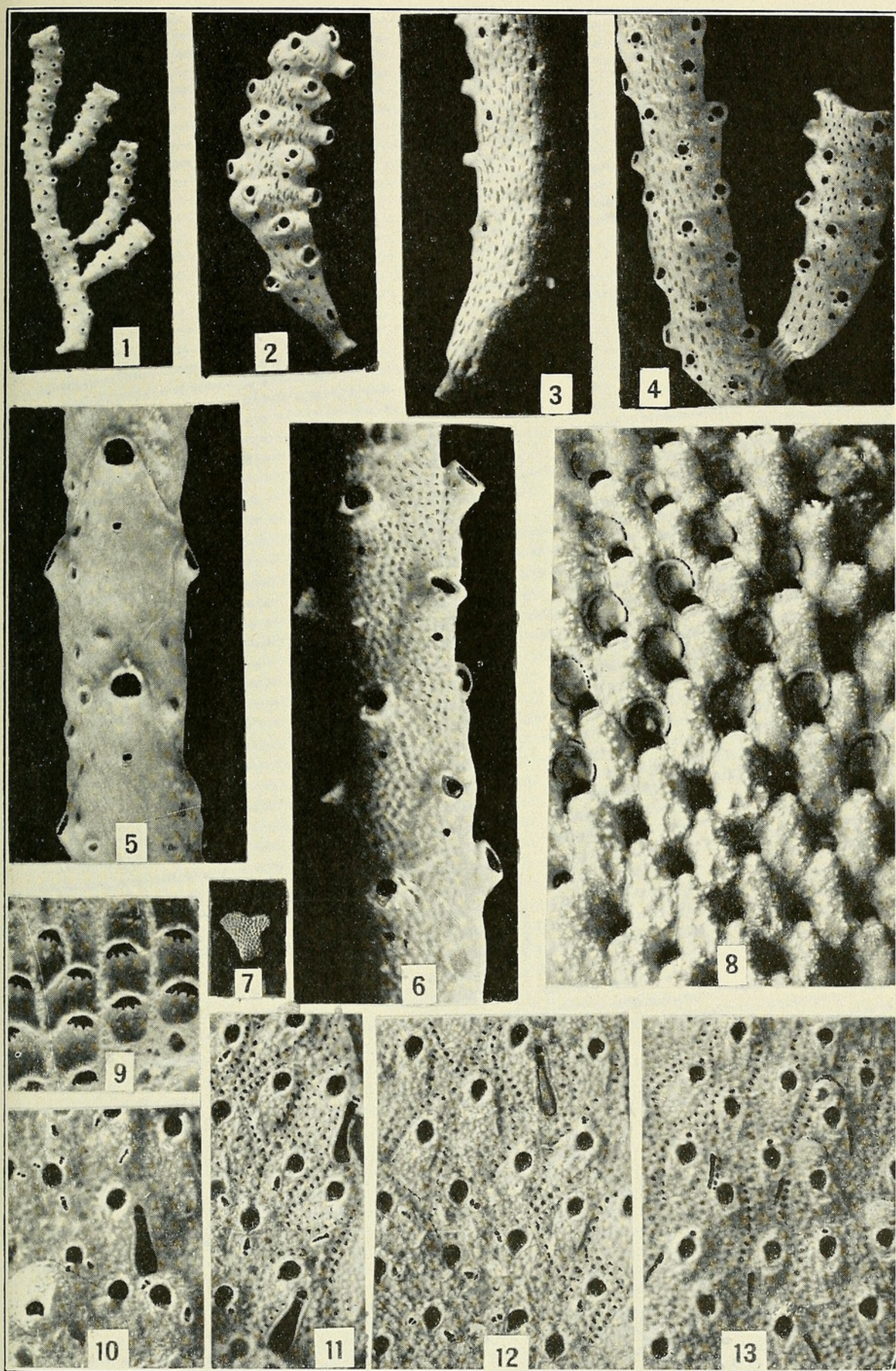

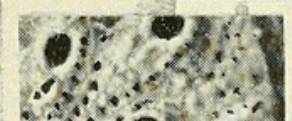
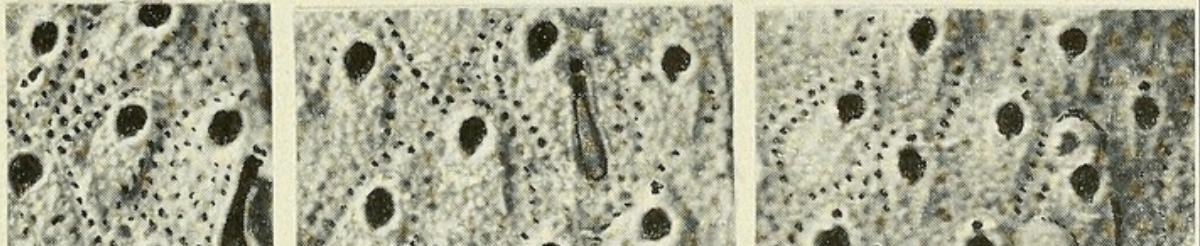

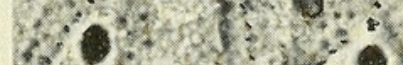

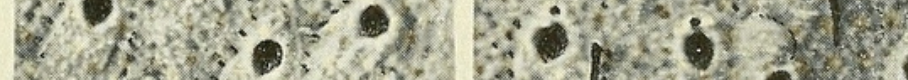
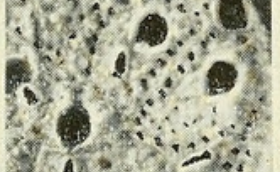

Q.1. 6. x.t.

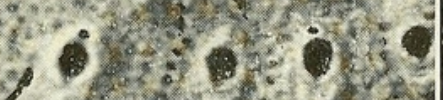

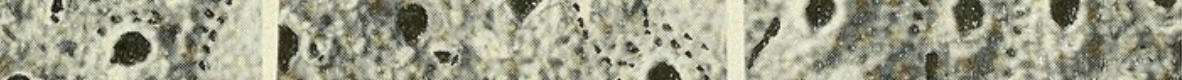

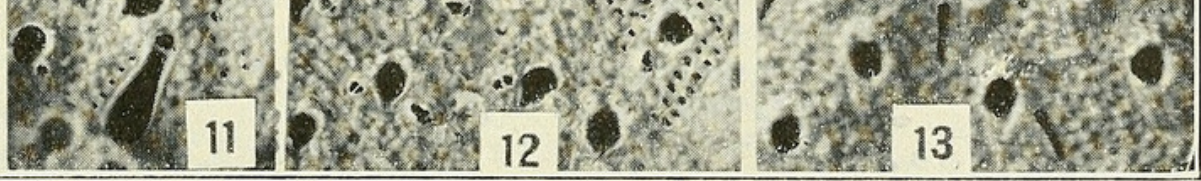

Bryozoa of the Gulf of Mexico Region 


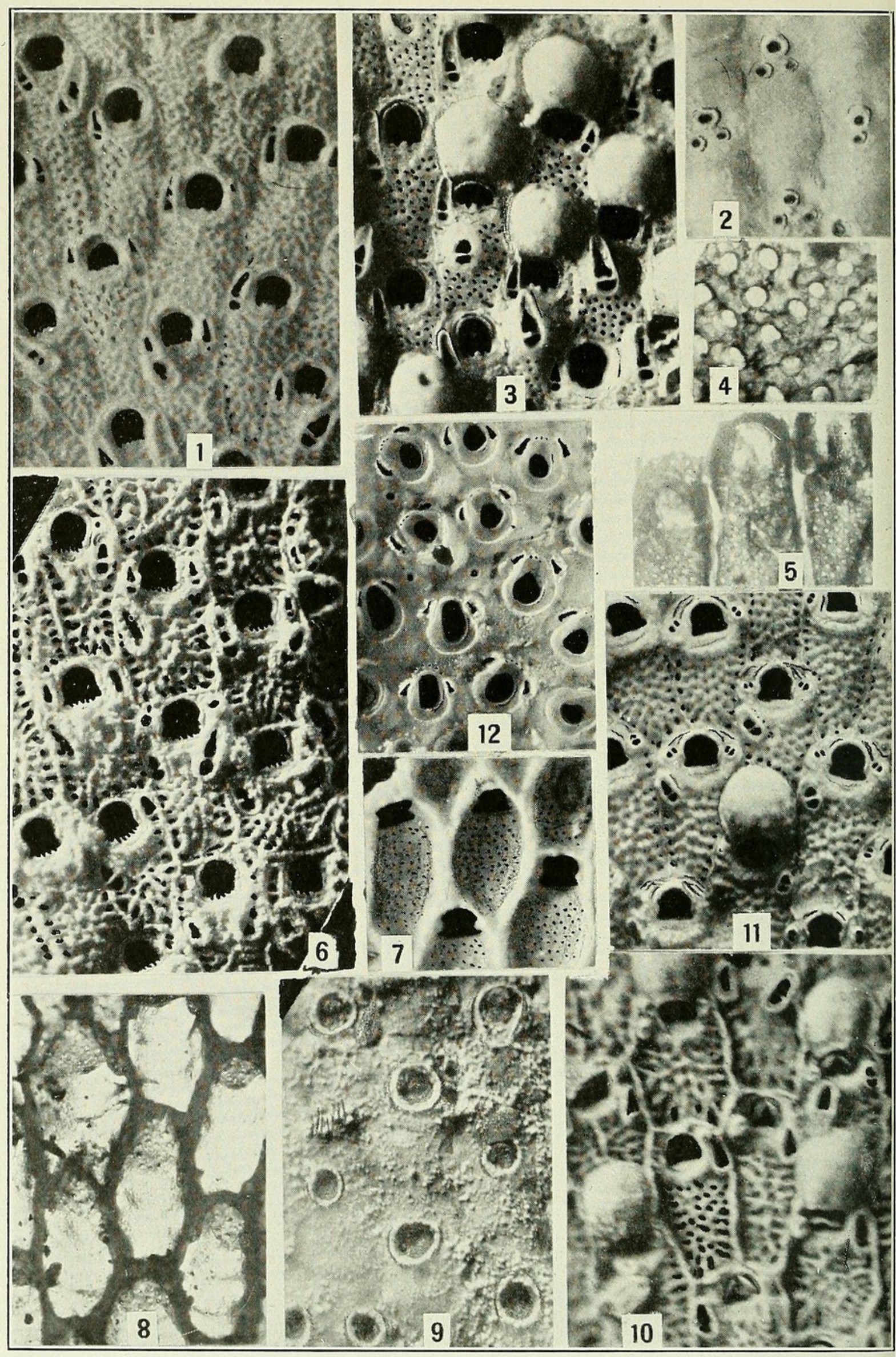

BryozoA of the Gulf of MExico Region

FOR DESCRIPTION SEE PAGE FACING 
Figs. 1-5. Petraliella bisinuata Smitt, 1873

1. Surface of the unilamellar zoarium; $\times 20$.

2. Inner face; $\times 20$. The radicular septules (cribriform areas of Waters) are placed in the distal portion of the cells.

Albatross Station D. 2405, Gulf of Mexico.

3. Operculated and ovicelled zooecia; $\times 20$. The lyrule and the cardelles are placed above the operculum.

4. Structure of the frontal; $\times 85$.

5. Frontal viewed by transparency; $\times 20$. The distal border of the operculum is visible. It is much chitinized. The operculum has no proximal limit but unites with the posterior walls of the compensatrix.

Albatross Station D. 2363, east of Yucatan.

6-11. Petraliella marginata, new species

6. Unilamellar specimen, much calcified; $\times 20$. The apertural avicularia are unequally developed and sometimes deformed by the large frontal avicularia.

7. Interior, $\times 20$, showing the two condyles of rotation of the operculum, and the tremopores.

8. Dorsal, viewed by transparency, $\times 20$, showing the structure of the radicular septules (cribriform areas of Waters).

9. Interior face of a unilamellar specimen; $\times 20$. The radicular septules are large.

10. Ovicelled zooecia much calcified; $\times 20$. The separating threads are quite salient. There are no frontal avicularia and the apertural avicularia are very large.

Albatross Station D. 2405, Gulf of Mexico.

11. Unilamellar specimen, ovicelled; $\times 20$. The large avicularium is lacking or little developed.

Albatross Station D. 2366, Gulf of Mexico, off Yucatan.

12. Antropora pustulata, new species. (See also pl. 3, fig. 11.) _-..-

The incrusting zoarium, $\times 20$, showing the interzooecial pustules.

Albatross Station D. 2167, off Habana, Cuba. 


\section{$2 \mathrm{BHL}$ Biodiversity Heritage Library}

1928. "Fossil and Recent Bryozoa of the Gulf of Mexico Region." Proceedings of the United States National Museum 72(2710), 1-199.

View This Item Online: https://www.biodiversitylibrary.org/item/100797

Permalink: $\underline{\text { https://www.biodiversitylibrary.org/partpdf/41026 }}$

\section{Holding Institution}

Smithsonian Libraries

\section{Sponsored by}

Biodiversity Heritage Library

\section{Copyright \& Reuse}

Copyright Status: Public domain. The BHL considers that this work is no longer under copyright protection.

This document was created from content at the Biodiversity Heritage Library, the world's largest open access digital library for biodiversity literature and archives. Visit BHL at https://www.biodiversitylibrary.org. 